\author{
UNIVERSIDADE DE SÃO PAULO \\ FACULDADE DE ODONTOLOGIA DE BAURU
}

MARINÊS VIEIRA S. SOUSA

Avaliação da influência do laser de baixa intensidade como recurso de ancoragem Ortodôntica e na supressão da dor

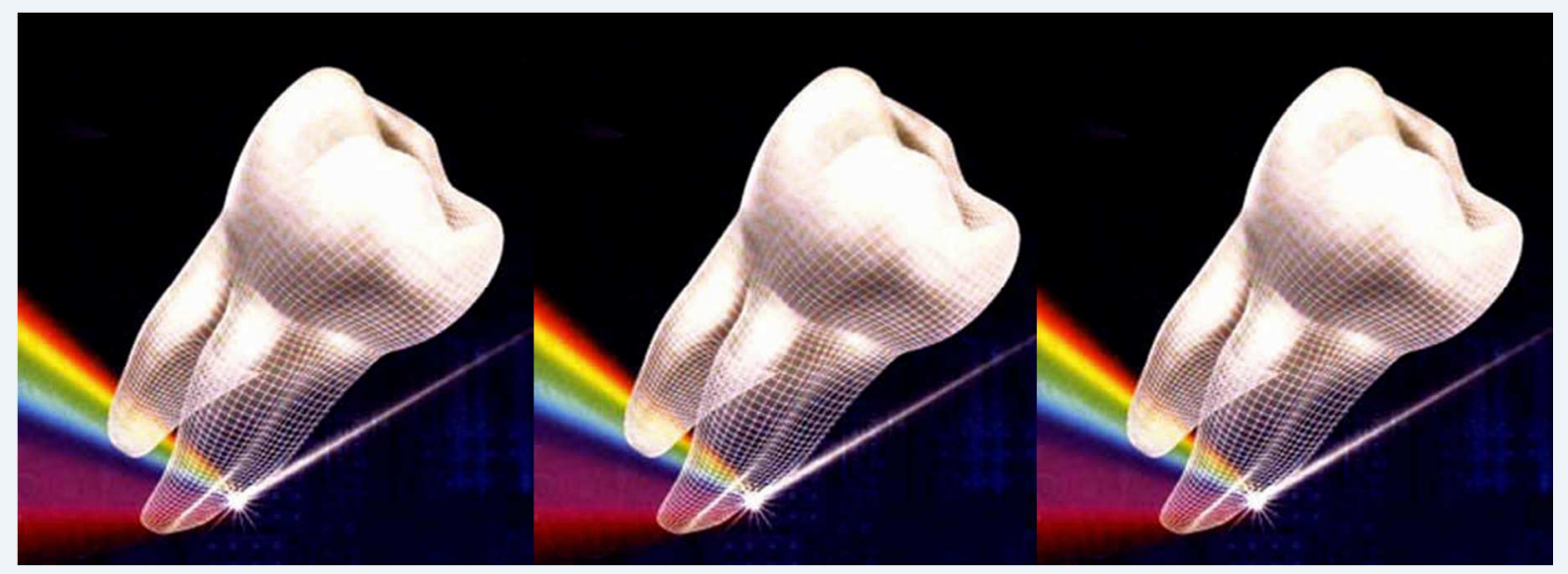

BAURU

2013 

MARINÊS VIEIRA S. SOUSA

\section{Avaliação da influência do laser de baixa intensidade como recurso de ancoragem Ortodôntica e na supressão da dor}

Tese apresentada à Faculdade de Odontologia de
Bauru da Universidade de São Paulo, para
obtenção do título de Doutor em Ciências
Odontológicas Aplicadas, área de concentração
Ortodontia

Orientador: Prof. Dr. Arnaldo Pinzan

Co-orientadora: Profa. Dra. Fernanda Angelieri

Versão Corrigida 


\begin{tabular}{|l|}
\hline Sousa, Marinês Vieira S. \\
So85a Avaliação da influência do laser de baixa \\
intensidade como recurso de ancoragem \\
Ortodôntica e na supressão da dor / Marinês \\
Vieira S. Sousa. - Bauru, 2013. \\
220 p. : il. ; 30cm. \\
Tese. (Doutorado) -- Faculdade de Odontologia \\
de Bauru. Universidade de São Paulo. \\
Orientador: Prof. Dr. Arnaldo Pinzan
\end{tabular}

Nota: A versão original desta tese encontra-se disponível no Serviço de Biblioteca e Documentação da Faculdade de Odontologia de Bauru - FOB/USP.

Autorizo, exclusivamente para fins acadêmicos e científicos, a reprodução total ou parcial desta dissertação/tese, por processos fotocopiadores e outros meios eletrônicos.

Assinatura:

Data:

Comitê de Ética da FOB-USP
Protocolo no: $133 / 2009$
Data: 06/07/2011


Nascimento

Fílíação

1988- 1991

1997-1999

2006-2008

2009-2013 o8 de Maio de 1967

São Paulo - S.P.

João Vieira da Síva

Nereide Martins da Silva

Curso de Graduação em Odontología Unesp - São José dos Campos

Curso de Aperfeiçoamento em Ortodontía - $\mathcal{N}$ EO - São Paulo

Curso de Pós-Graduação em Ortodontia em nivel de Mestrado, pela Universidade Metodista de São

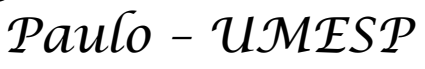

Curso de Pós-Graduação em Ortodontia, em nível de Doutorado pela Faculdade de Odontologia de Bauru - Universidade de São Paulo 

Houve um tempo em que eu era uma muther e você, um homem. Mas, nosso amor cresceu, até não existir maís nem você, nem eu. Lembro-me apenas, vagamente, que antes éramos dois e que o amor, intrometendo-se, tornou-nos um só.

Dedico este trabalho ao meu esposo, amigo e companheiro:

\section{REIN $\mathcal{A} \mathcal{L} D O \mathcal{T}$ SOUSA}

Caminhar a seu lado me dá a certeza da vitóría, porque me sinto amparada pelo seu amor, incentivo e apoio incondicional.

$\mathcal{N}$ ão consígo maís me ver sem pensar em você ao meu lado. Te amo. 



\section{Agradeço à Deus}

Toda minha gratídão àquele que é digno de louvor e que me concedeu a imensa alegria de sentir o teu grande amor. Um amor que curou as minhas feridas, trouxe-me amparo nas adversidades e ensinou-me o real significado do perdão e do verdadeiro amor. Agradeço a sabedoría que tenho recebido dia após día. Reconheço minha pequenez e fragilidade, e por isso sinto-me feliz em poder saber que tens direcionado os meus passos. 



\section{Aos meus filhos Bárbara e Bruno}

Há momentos que nem as mais belas palavras podem transmitir o intenso e forte sentimento, e para esses momentos cabe o olhar...

Olhando para vocês tenho a convicção de que o methor e maior projeto de toda a minha vida, sem dúvida nenhuma, foi tê-los como fithos, fazendo parte da minha vida. Agradeço a vocês pela paciência e pelo tempo roubado.

o tempo roubado não se consegue de volta, mas o tempo presente é possivelfazer valer à pena. Amo vocês! 

"A vida não se mede pelo tempo que durou e sim por momentos especiais que se eternizou”.

Aos meus pais: João Vieira da Silva e Nereide Martins da Silva

Pelos sábios ensinamentos que recebi de vocês. Pelos valores de vida que me transmitiram, por tudo que abdicaram na vida em função dos fîhos e por tudo que sou hoje, meu muito obrigada!

Amo vocês!

Agradeço aos meus irmãos: João Carlos, João Luiz e María Lúcia, a meus cunhados e cunhadas, a minha sogra e a meus sobrinhos e sobrinhas...

Pela compreensão nos momentos que estive ausente durante este período e pelo apoío e incentivo que sempre me deram. Amo vocês! 



\section{Agradecimento Especial}

Ao meu orientador: Dr Arnaldo Pinzan

Pensei muito em escrever palavras que realmente pudessem traduzir tudo o que o senhor significou na minha vida acadêmica e profissional. Transmitir conhecimentos técnicos vai além do seu dom. Um verdadeiro mestre, professor e orientador passa uma históría de vida e isso faz toda a diferença.

Durante este tempo que aqui estive recebi muito mais do que os seus sábios ensinamentos... Enxergar onde os othos não veem, entender aquilo que é indecifrável à compreensão humana, alegrar-se por simplesmente o dia amanhecer, somente uma pessoa de Deus é capaz de realizar tais feitos.

\section{À̀ você Dr. Arnaldo, meu eterno agradecimento.}

Espero um dia poder representar aos meus alunos tudo aquílo que o Sr. representou e representa para mim.

Que Deus o abençoe em todos os momentos de sua vida! 

À minha co-orientadora e "eterna orientadora":

Dra. Fernanda Angelieri

Sua dedicação e exemplo de vida faz de você uma pessoa admirável.

Obrigada por tudo que tem feito por mím.

Sigo os seus passos...

Aos professores da disciplina de Ortodontía da faculdade de Bauru:

Prof. Dr. Arnaldo Pinzan

Profa. Dra. Daniela Gamba Garíb

Prof. Dr. Décío Rodrígues Martíns

Prof. Dr. Guitherme Janson

Prof. Dr. José Fernando Castanha Henriques

Prof. Dr. Marcos Roberto de Freitas

Prof. Dr. Renato Rodrigues de Almeida

Minha eterna gratidão pelos conhecimentos transmitidos.

Levarei um pouco de cada um para onde quer que eu vá. Obrigada por tudo! 

Aos professores da FOB, especialmente Prof. Dr. Alberto

Consolaro e Prof. Dr. Rodrígo Cardoso...

...que gentilmente abriram-me as portas do departamento de Patología e de Bioquímica onde pude ampliar meus conhecimentos, tendo a oportunidade de desenvolver uma pesquisa em animais associado à movimentação ortodôntica e Caserterapia.

Meu muito obrigada!

Aos meus queridos amigos de doutorado:

Eduardo Lenza, obrigada pela amizade e pelo carinho que sempre teve por mim. Obrigada por compartithar comigo a sua companhia nas caronas para Bauru. Admiro muito você.

Eliziane Cossetin, agradeço a amizade e os inúmeros momentos que estivemos trabalhando juntas em tantos projetos e pesquísas. Desejo a você muito sucesso e que Deus a abençoe na sua jornada.

Juliana Morais, agradeço seu carinho e amizade. Você é uma pessoa muito especial. $\mathcal{N}$ asceu para vencer. Obrigada por tudo! 

Luiz Eduardo, nesses anos de convivência, acabei te adotando como filtho e por isso tenho um carinho muito especíal por você. Torço pelo seu sucesso, como uma mãe torce por um fílho.

Michelle Cassis, a noiva do ano! Sua estrela nasceu para brilhar. Obrigada pela amizade e pelo carinho.

Núria C. Branco, Thais Fernandes e Renata Sather, obrigada pela amizade e principalmente pela acolhida. Lembro-me perfeitamente no día da prova de seleção para o doutorado o quanto foi importante para mím o carinho com que fui recebida por vocês. Isto fez toda a diferença.

Agradeço o bom convívio, as experiências compartilhadas e os laços de amizade que com certeza farão nos reencontrarmos em algum lugar no futuro... Um Grinde à nossa amizade!

Aos colegas de doutorado novo: Carolina Menezes, Daniel Salvatore, Francyle Sanches, Juliana Storniolo, Manoela Francisconi, Marcos Ferreira, Patrícia Santos, Roberto Bombonatti, Roberto Grec e Suelen Pereira. 

Aos colegas de Mestrado: Caroline Bronfman, Cintia Junqueira, Daniela Pupulim, Fernanda Fontes, Fernando Dias, Larissa Bressane, Lucas Mendes, Lucas Sílva, Marília Yatabe, Roberta Handem, Thais Rocha e Valéria Bezerra

"Que Deus abençoe vocês todos e ilumine vossos caminhos onde quer estejam".

Aos funcionários da disciplina de Ortodontía da $\mathcal{F O B}-\mathcal{U} \mathcal{L}$, Cristina, Neide, Sérgio, Vera, Wagner, Cleonice e Tía María. Meus sinceros agradecimentos pela agradável convívêncía e por colaborarem com os afazeres deste curso.

\section{Agradeço especialmente:}

’̀ Vera Purgato, mais do que uma funcionáría competente, uma verdadeira amiga... Sempre solícita e disposta a ajudar. Obrígada pelo carínho e por tudo que fez por mim.

Ao Daniel Bonné, sempre feliz e solícito. Admiro pela sua habilidade no que faz, mas principalmente pela pessoa que é e pela maneira como encara a vida. Que Deus o abençoe. Obrigada por tudo! 

Aos protéticos e amigos: Dr. Sérgío Vieira e Wagner Baptista que fazem questão de tornar qualquer dia um "día feliz". Obrigada por confeccionarem os aparelhos dos pacientes da minha amostra.

$\mathcal{A}$ Neide Maria de Souza: Vou sentir saudades do seu "bom día" e do seu abraço síncero e amígo. Muito obrígada pela acolhida. Que Deus a abençoe!

Ao Prof. Dr. Heitor Marques Honórí que muito contríbuiu para as análíses estatísticas desta tese.

Meu muito obrigada.

À empresa Radio Memory pela gentileza em disponibilizarme o software "radiocef" para a análise das tomografías e especialmente ao Dr. Aécío Fonseca, consultor científíco desta empresa que trabalhou arduamente durante 8 meses na elaboração da análise $3 \mathcal{D}$, específica para esta tese. Meu muitíssimo obrígada. 

$\mathcal{A}$ Universidade Metodista de São Paulo, representada pelo Prof. Dr. Rogérío Gentil Bellot e ao Prof. Dr. Marco Antonio Scanavini, que muito gentímente permitiu o atendímento dos pacientes da amostra na clínica de Ortodontía da pósgraduação.

Aos meus pacientes, indíspensáveis para a realização deste trabalho e que acabei criando um vínculo de muito amor e carinho, especialmente à Sarah $\mathcal{N}$ eres, que atualmente é minha auxilíar.

\section{Ao pessoal do SEOM (Clinica de Odontologia)}

Agradeço imensamente o apoío de todos os profíssionais, funcionáríos e pacientes que na verdade são verdadeiros amigos.

Sei que torcem por mim e sou muito grata por isso.

Ao meu "Graço direito" e sempre amiga: Lucía Elena, que por longos anos e até hoje, sempre esteve ao meu lado cuidando da minha familía.

Meu muitíssimo obrigada e que Deus a abençoe por tudo que tem feito por nós! 

Agradecimentos administrativos:

A Faculdade de Odontologia de Bauru, Universidade de São Paulo, representada pelo Professor Dr. José Carlos Pereira, diretor desta Faculdade e à vice-diretora Profa. Dra. María Aparecida de A. Moreira Machado.

À CAPES pela concessão de bolsa de estudo durante o curso de doutorado

"Por fim, digo a todos que muito recebi... termino esta etapa levando em meu coração uma imensa gratidão e o sentimento de missão cumprida"

MUITO OBRIGADA $\mathcal{A} !$ 



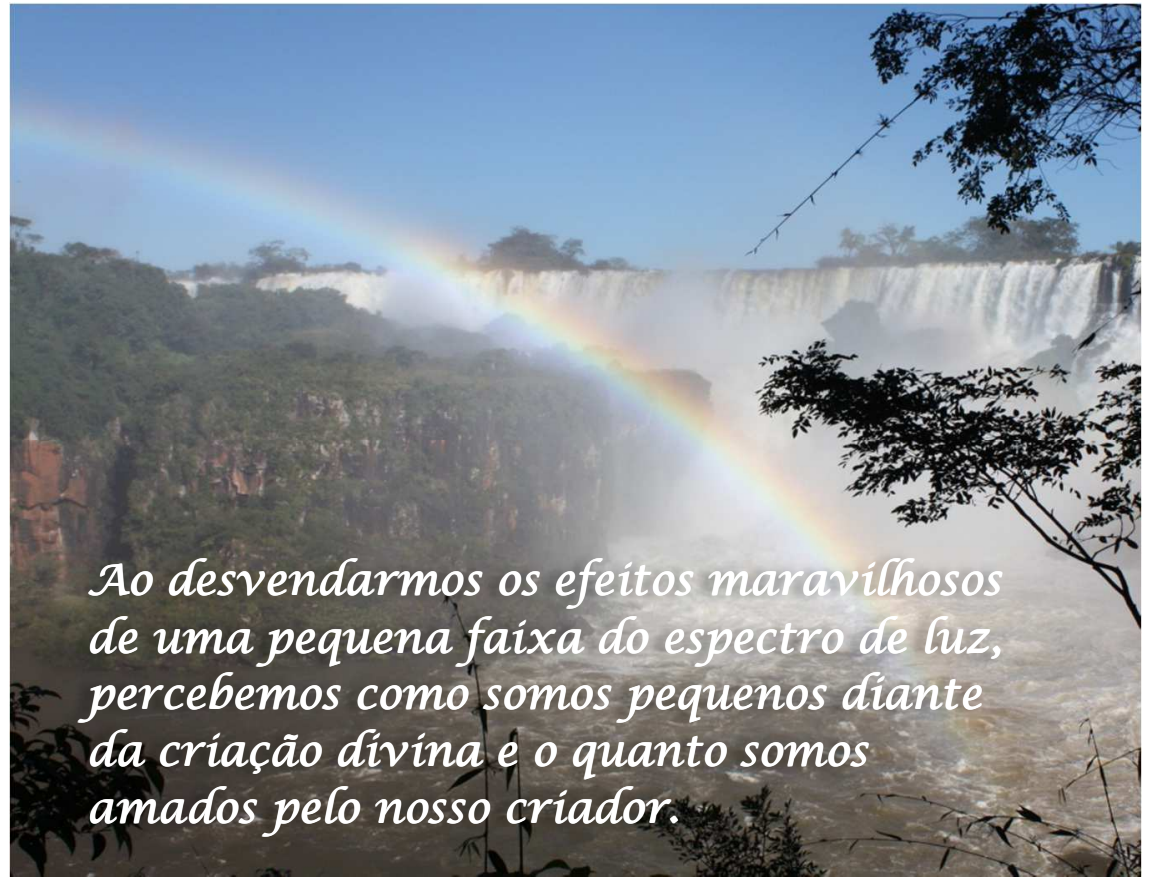



Resumo

"A mente que se abre a uma nova ideia, jamais voltará ao seu tamanho original."

Albert Einstein 



\section{RESUMO}

Este estudo investigou os efeitos do laser em baixa intensidade na movimentação ortodôntica com a intenção de promover a ancoragem e a inibição da dor pós-ativação, bem como a verificação da preservação da integridade tecidual. A amostra constou de um total de 74 molares e pré-molares superiores e inferiores que serviram de ancoragem na fase de retração inicial de caninos realizada com molas de $\mathrm{NiTi}$, com força de $150 \mathrm{~g}$. Um dos molares/pré-molares escolhido aleatoriamente foi irradiado com laser de diodo (LI), seguindo o seguinte protocolo de aplicação: $780 \mathrm{~mm} / 70 \mathrm{~mW} / 105 \mathrm{~J} / \mathrm{cm}^{2} / 4,2 \mathrm{~J}$ por ponto/Et= $42 \mathrm{~J}$ para os molares e $42 \mathrm{~J}$ para os prémolares nos dias 0,7 e 14 pós-ativação, sendo que o contralateral foi considerado placebo (LNI). A retração durou em média 3 meses, num total de 9 aplicações de laser. Utilizou-se modelos de gesso e tomografias computadorizadas do feixe cônico (TCFC) para a verificação da perda de ancoragem dos molares. Os modelos adquiridos a cada mês foram medidos com paquímetro digital e as tomografias adquiridas nos tempos iniciais (T0) e finais (T4) foram analisadas por meio da análise 3D (Radiomemory). Nas tomografias foi também avaliada uma possível reabsorção na crista óssea alveolar (CA), por meio da distância desta (CA) até a junção cementoesmalte (JCE), comparando-se T0 e T4 e a quantidade de reabsorção radicular, por meio da diferença de comprimento radicular inicial e final. Para avaliação da sintomatologia dolorosa comparando-se o LI e o LNI foi utilizado uma escala visual analógica após 12, 24, 48 e 72 horas após a irradiação, na qual os pacientes marcavam de 0 a 10 em consonância com a dor experimentada. Para os modelos, empregou-se a análise da variância a dois critérios e a um critério, seguido pelo teste de Tukey, em seguida aplicou-se o teste "t" pareado, para a mensuração da diferença total comparando-se o lado irradiado (LI) com o lado não irradiado (LNI). Para as tomografias na comparação entre os tempos T0 e T4 da perda de ancoragem, reabsorção radicular e crista óssea alveolar comparando-se o LI com o LNI foi utilizado o teste " $\mathrm{t}$ " pareado. Foi aplicado o teste paramétrico de Wilcoxon e para verificação da diferença da dor experimentada entre os tempos, o teste não paramétrico de Friedman. Em todos os testes adotou-se o nível de significância de $5 \%$. Em modelos, para comparação entre os tempos, os resultados indicaram que houve uma diminuição estatisticamente significante na velocidade da movimentação dos molares irradiados comparados ao seu contralateral somente no primeiro mês, porém houve uma diferença estatisticamente significante comparando-se o tempo T0 e T4 tanto em modelos como em tomografias. Houve também uma diminuição estatisticamente significante da sintomatologia dolorosa, comparados o LI com o LNI e uma menor perda de tecido ósseo na crista óssea distal e vestibular do primeiro molar superior de forma estatisticamente significante. Concluiu-se que a laserterapia, com a dosimetria adotada, pode diminuir a movimentação dos dentes empregados como ancoragem na fase de retração inicial de caninos, como também diminuir a sintomatologia dolorosa, sem causar danos aos tecidos.

Palavras-chave: Lasers. Movimentação Dentária. Procedimento de Ancoragem Ortodôntica. Analgesia 



\section{Abstract}

"Se os fatos não se encaixam na teoria, modifiquem os fatos."

Albert Einstein 



\section{ABSTRACT}

This study investigated the effects of low level laser in orthodontic movement, aiming to promote anchorage and inhibition of pain after activation, as well as to analyze the maintenance of tissue integrity after utilization of laser and orthodontic movement. The sample was composed of 74 maxillary and mandibular molars and premolars that served as anchorage in the initial retraction stage of canines, performed with $\mathrm{NiTi}$ coil springs with force of $150 \mathrm{~g}$. One of the randomly selected molars/premolars was irradiated with diode laser (LI), according to the following application protocol: $780 \mathrm{~mm} / 70 \mathrm{~mW} / 105 \mathrm{~J} / \mathrm{cm}^{2} / 4.2 \mathrm{~J}$ per point $/ E \mathrm{t}=42 \mathrm{~J}$ for molars and 42J for premolars at days 0,7 and 14 after activation, and the contralateral tooth was considered as (LNI). The retraction lasted 3 months in the average, adding up to 9 laser applications. Dental casts and cone beam computed tomographies (CBCT) were evaluated to analyze the anchorage loss of molars. The dental casts obtained every month were measured with a digital pachymeter and the tomographies obtained at initial (T0) and final periods (T4) were assessed by 3D analysis (Radiomemory). The tomographies were also assessed to evaluate a possible resorption of the alveolar bone crest $(C A)$, by measuring the distance between it $(C A)$ and the cementoenamel junction (JCE), comparing T0 and T4 and the quantity of root resorption, by the difference between the initial and final root lengths. The painful symptomatology was analyzed by comparison of LI and LNI using a visual analogue scale after 12, 24, 48 and 72 hours, in which the patients indicated from 0 to 10 according to the pain experienced. For the dental casts, two-way and one-way analysis of variance were applied, followed by the Tukey test and then by the paired t test, for measurement of the total difference comparing the irradiated (LI) and non-irradiated (LNI) sides. The paired t test was applied for comparison between periods T0 and T4 of anchorage loss, root resorption and alveolar bone crest, comparing the LI and LNI. The parametric Wilcoxon test was applied, and the difference in experienced pain between periods was analyzed by the non-parametric Friedman test. All tests were performed at a significance level of $5 \%$. In dental casts, for comparison between periods, the results indicated statistically significant reduction in the rate of movement of irradiated molars compared to the contralateral only on the first month, yet there was statistically significant difference comparing the periods T0 and T4. In the tomographies, there was statistically significant difference in the rate of movement comparing T0 and T4. There was also statistically significant reduction of painful symptomatology when LI was compared to LNI, with statistically significant gain of bone tissue at the distal bone crests of the maxillary first molar. It was concluded that laser therapy at the adopted dose may reduce the orthodontic movement of the anchorage teeth's in the stage of initial retraction of canines, as well as reducing the painful symptomatology without damage to the periodontal tissues and even contributing to increase the bone support.

Key words: Lasers. Tooth Movement. Orthodontic Anchorage Procedures. Analgesia. 



\section{LISTA DE ILUSTRAÇÕES}

- FIGURAS

Figura 1 - Sequência de eventos que ocorrem pela aplicação de uma força ortodôntica.

Figura 2 - Principais eventos celulares desencadeados após a laserterapia em osteoblastos.

Figura 3 - Fluxograma dos resultados das pesquisas nas bases de dados e das diferentes fases de seleção dos artigos que avaliaram a influência do laser em baixa intensidade na movimentação ortodôntica em humanos.

Figura 4 - Pontos de aplicação do laser encontrados na literatura

Figura 5 - Representação esquemática dos principais fatores envolvidos na indução da dor relacionado ao movimento ortodôntico

Figura 6 - Fluxograma dos resultados das pesquisas nas bases de dados e das diferentes fases de seleção dos artigos que avaliaram a influência do laser em baixa intensidade na analgesia pós-movimentação ortodôntica. 66

Figura 7 - Figura extraída do artigo de Patcas: Em E: IE: borda incisal; ABM: crista óssea alveolar; MGJ: junção mucogengival; $\mathrm{H}$ : medida horizontal. Em A: Tomografia corte frontal; Em B: Tomografia - corte sagitais; C e D: Fenestrações nas peças anatômicas.

Figura 8 - Fotos extrabucais frontal, sorriso e lateral de um paciente selecionado para a amostra.

Figura 9 - Fotos intrabucais frontal, lateral esquerda e lateral direita de um paciente selecionado para a amostra. 93

Figura 10 - Fotos intrabucais, frontal, lateral direita e lateral esquerda de um paciente selecionado para a amostra mostrando os arcos segmentados e a molas instaladas, como também o levante de mordida nas cúspides mesiais dos segundos molares inferiores (circulados). 

Figura 11 - Aparelho de laser e visor ampliado com os parâmetros de aplicação programados .

Figura 12 - Pontos de aplicação do laser na região vestibular. Os mesmos pontos foram aplicados por lingual, num total de 16 pontos.

Figura 13 - Em A, deslocamento dos molares mensurados por meio de um paquímetro digital e em $\mathrm{B}$, pontos de referência utilizados: ponto 1 e 2 , fossa central dos primeiros molares direito e esquerdo e ponto 3 , papila entre os incisivos na sua porção mais central. DPMi: distância linear entre a papila e o primeiro molar do lado irradiado e DPMni: distância linear entre a papila e o primeiro molar do lado não irradiado.

Figura 14 - Obtenção da telerradiografia lateral direita a partir da imagem tridimensional no programa Dolphin. 104

Figura 15 - Recurso para calibração da imagem no programa Radiocef Studio2. 105

Figura 16 - Pontos, linhas e planos de referência, exemplificado numa telerradiografia em norma lateral antes das extrações. 108

Figura 17 - Em A, representação esquemática das medidas angulares e lineares nos molares e caninos superiores e em $B$, representação esquemática das medidas angulares e lineares nos molares e caninos inferiores.

Figura 18 - Reconstrução multiplanar: em A, plano coronal; em B, plano sagital; em $\mathrm{C}$, plano axial e em $\mathrm{C}$, reconstrução 3D.

Figura 19 - Pontos de referência e medidas lineares para as medidas do comprimento linear máximo. Em A, B, D, E, $F$, $G$ e $H$, medidas realizadas no plano sagital e em $B$, medidas realizadas no plano coronal. 

Figura 20 - Exemplificação de algumas medidas da crista óssea alveolar (em $\mathrm{mm}$ ) com seu correspondente esquema abaixo: Em A, mesial e distal do primeiro molar superior (plano sagital); em $B$, vestibular e lingual do primeiro molar superior (plano coronal); em C, vestibular e ligual do canino superior (plano sagital) e em $D$, vestibular e lingual do segundo pré-molar superior (plano sagital).

- GRÁFICOS

Gráfico 1A - Primeiro mês - Teste de Wilcoxon: Asterisco $\left({ }^{*}\right)$ significa diferença estatisticamente significante $(p<0,05)$, entre os dentes irradiados e os não irradiados. Teste de Friedman: tempos com letras iguais não possuem diferenças estatisticamente significantes entre si.

Gráfico 1B - Segundo mês - Teste de Wilcoxon: Asterisco ( $\left.{ }^{*}\right)$ significa diferença estatisticamente significante $(p<0,05)$, entre os dentes irradiados e os não irradiados. Teste de Friedman: tempos com letras iguais não possuem diferenças estatisticamente significantes entre si

Gráfico 1C-Terceiro mês - Teste de Wilcoxon: Asterisco ( $\left.{ }^{*}\right)$ significa diferença estatisticamente significante $(p<0,05)$, entre os dentes irradiados e os não irradiados. Teste de Friedman: tempos com letras iguais não possuem diferenças estatisticamente significantes entre si

Gráfico 2 - Comparação da quantidade de movimentação dos molares irradiados em relação aos não irradiados $(\mathrm{mm})$ medido em modelos, nos períodos de tempo avaliados.

Gráfico 3 - Média em mm da perda de ancoragem em tomografias comparando-se o grupo de molares irradiados com os molares não irradiados.

Gráfico 4 - Janela Terapêutica 155 



\section{LISTA DE TABELAS E QUADROS}

\section{- TABELAS}

Tabela 1 - Interpretação da dosagem relativa / TCFC

Tabela 2 - Erro do método nos modelos (medidas em mm); teste "t" pareado e fórmula de Dahlberg.

Tabela 3 - Erro do método das medidas dos lados direito irradiado e não irradiado realizadas nas tomografias computadorizadas cone beam $(\mathrm{mm})$ para mensuração da ancoragem dos molares, retração dos caninos e angulação dos molares e caninos - teste "t" pareado e fórmula de Dahlberg.

Tabela 4 - Erro do método das medidas realizadas nas tomografias computadorizadas cone beam $(\mathrm{mm})$ para reabsorção radicular e mensuração da crista marginal teste " $\mathrm{t}$ " pareado e fórmula de Dahlberg.

Tabela 5 - Descrição da Média e Desvio padrão em todos os tempos avaliados do primeiro ao terceiro mês - lado irradiado (LI) e lado não irradiado (LNI)

Tabela 6 - Percentual de redução da dor em todos os tempos avaliados que tiveram significância estatística.

Tabela 7 - Quantidade de movimentação dos molares em mm medido em modelos nos períodos de tempo avaliados, para o grupo irradiado e não irradiado - Teste de Tukey.

Tabela 8 - Quantidade de movimentação dos molares em mm, medido em modelos nos períodos de tempo avaliados, para o grupo irradiado e não irradiado - Teste $t$ pareado.

Tabela 9 - Quantidade média de movimentação dos molares em $\mathrm{mm}$, medido em tomografias, comparando-se o tempo inicial com o final, para o grupo irradiado e não irradiado - Teste t pareado.

Tabela 10 - Alterações médias promovidas pela retração inicial dos caninos - arco dentário superior e inferior - teste "t" pareado. $\mathrm{Ml}=$ Molar Irradiado; $\mathrm{MNI}=$ Molar Não irradiado; LI= Lado Irradiado; LNI= Lado Não irradiado. 

Tabela 11 - reabsorção radicular medida a distância do ápice radicular até cúspide/incisal em $\mathrm{mm}$ (T4-T0), comparando-se o lado irradiado com o lado não irradiado. Teste "t" pareado.

Tabela 12 - diferença da altura da crista óssea alveolar medida a distância CA-JCE em mm (T4-T0), comparando-se o lado irradiado com o lado não irradiado, tanto para o arco superior como para o inferior. Teste "t" pareado.

\section{- QUADROS}

Quadro 1 - Resumo das dosimetrias encontradas na literatura e seus efeitos em humanos para o estímulo da movimentação dentária induzida ortodonticamente

Quadro 2 - Dosimetrias utilizadas pelos autores na intenção de analgesia pós-ativação ortodôntica

Quadro 3 - Cronologia dos Procedimentos 



\section{LISTA DE ABREVIATURAS E SIGLAS}

Laserterapia ou Laser Terapêutico

$\mathrm{LAl}$

Laser em Alta Intensidade

LBI

Laser em Baixa Intensidade

$\mathrm{He}-\mathrm{Ne}$

Helio-Neônio

AsGa

Arseneto de Galio

AsGaAl (diodo)

Arseneto de Galio e Alumínio

LP

Ligamento Periodontal

FG

Fluido Gengival

EGF

Fator de Crescimento Epidérmico

ATP

Adenosina Trifosfato

GTP

Guanosina Trifosfato

RANKL

Receptor de Ativação do Fator Nuclear Kappa B Ligante

OPG

Osteoprotegerina

J

Joules

$\mathrm{mW}$

miliwatts

$\mathrm{nm}$

nanômetros

$\mathrm{P}$

Potência

DE

Densidade de Energia

DP

Densidade de Potência

$\lambda$

comprimento de onda

E

Energia

$P G$

Prostaglandinas

IL

Interleucina

TC

Tomografia Computadorizada

TCFC

Tomografia Computadorizada do Feixe Cônico 



\section{SUMÁRIO}

2

2.1

2.2

2.3

2.4

3

4

4.1

4.1.1

4.1.1.1

4.2

4.2.1

4.2 .2

4.2 .3

4.2 .4

4.2 .5

4.2.5.1

4.2.5.2

4.2.5.3

4.2.5.4

4.2.5.5

4.2.5.6

4.2 .6

4.2.6.1.

4.2.6.2.

4.2 .7

4.2 .8

4.2.8.1

4.2.8.2

\section{REVISÃO DA LITERATURA}

Força ortodôntica e reações celulares, moleculares e teciduais 35

Terapia com laser em baixa intensidade em Ortodontia ....................41

Ancoragem ortodôntica .73

Tomografia computadorizada feixe cônico 76

PROPOSIÇÃO 85

MATERIAL E MÉTODOS 89

Material .91

Amostra.... 91

Dados dos pacientes da amostra. 92

Métodos 94

Tratamento ortodôntico 94 Aplicação do laser 96

Avaliação da sensibilidade dolorosa ... 102

Análise dos modelos 102

Análise cefalométrica nas tomografias. 103 Obtenção da tomografia computadorizada do feixe cônico (cone beam). 103

Obtenção das telerradiografias direita e esquerda. 104 Pontos Cefalométricos. 106

Linhas e planos de referência 107 Variáveis analisadas nos molares 109 Variáveis analisadas nos caninos 110 Avaliação da reabsorção radicular e crista óssea alveolar.... 112

Avaliação da reabsorção radicular 112 Avaliação da crista óssea alveolar .... 114

Avaliação da dor - análise estatística .......................................116

Erro do Método. 116

Erro do método - modelos de estudo 116

Erro do método - tomografias computadorizadas. 117 

5.3 Análise da perda de ancoragem dos molares avaliada nos modelos de estudo sob a influência do laser.

$5.4 \quad$ Análise das tomografias computadorizadas cone beam

5.4.1 Análise da perda de ancoragem dos molares sob a influência do laser.

5.4.2 Análise das alterações promovidas pela retração inicial dos caninos sob a influência do laser.

5.4.3 Análise da reabsorção radicular e da crista óssea alveolar sob a influência do laser.

6.1 Seleção da amostra e metodologia adotada ................................137

REFERÊNCIAS.

APÊNDICE 193

ANEXO 



\section{Introdução}

"Se, a princípio, a idéia não é absurda, então não há esperança para ela."

Albert Einstein 



\section{INTRODUÇÃO}

O fascínio do ser humano pela luz é um arquétipo, ou seja, está registrado no inconsciente coletivo da mente humana. Os deuses solares da antiguidade eram considerados deuses da saúde e da cura.

Gregos e romanos sabiam empiricamente que a luz solar contribuía para cura, só não conheciam exatamente o seu mecanismo de ação. Em 1400a.C., os indianos foram os primeiros a utilizar a fotoquimioterapia, por meio de uma pomada natural (fotossensibilizador exógeno obtido de plantas - psorales), capaz de absorver luz solar, promovendo um efeito terapêutico no tratamento do vitiligo (BRUGNERA; ZANIN, 2001). Passado mais de 3 mil anos, ainda hoje, uma das formas de tratamento do vitiligo é a fotoquimioterapia associada ao uso de psoralenos.

Em 1903, Dr. Niels Ryberg Finsen recebeu um prêmio Nobel em Medicina, por tratar uma forma desfigurante de tuberculose da pele com luz solar (BRUGNERA; ZANIN, 2001; BRUGNERA; LADALARDO; CRUZ, 2003; GUTKNECHT; FRANZEN, 2004; GENOVESE, 2007; SOUSA et al., 2010)

Em 1917, Albert Einstein foi o responsável pelas bases teóricas para o estudo do laser, utilizando o princípio físico da emissão estimulada de radiação (EINSTEIN, A, 1917). Contudo, com o descobrimento da penicilina, em 1938, a ciência passou a estudar com afinco o desenvolvimento dos fármacos, acreditando-se que a penicilina seria a cura para quase todas as doenças. Por este motivo, as pesquisas para o desenvolvimento de um aparelho que pudesse emitir somente a luz laser foi relegada a um segundo plano. Os pesquisadores da época só não contavam com os efeitos colaterais dos antibióticos, nem tampouco com a resistência bacteriana por eles desenvolvida.

Somente em meados do século XX, houve a descoberta e o desenvolvimento dos aparelhos de lasers. Maiman, em 1960, construiu o primeiro laser de rubi (laser cirúrgico) após exatamente 43 anos dos estudos teóricos de Einstein para sua idealização. Um ano depois (1961), foi realizada a primeira cirurgia à laser para a remoção de um pequeno tumor de retina (GENOVESE, 2007) e somente em 1965, Sinclair e Knoll desenvolveram o aparelho de laser em baixa intensidade ou laser 
terapêutico, não mais com o efeito de corte, mas de biomodulação dos tecidos (NEVES, et al., 2005; GENOVESE, 2007; SOUSA et al., 2010).

A palavra LASER é um acrônimo ou uma forma abreviada formada pelas iniciais da palavra LASER, que significa: "Light Amplification by Stimulated Emission of Radiation", ou seja, amplificação da luz por emissão estimulada de radiação, processo pelo qual uma forma de energia se converte em energia luminosa (BRUGNERA; ZANIN, 2001; BRUGNERA; LADALARDO; CRUZ, 2003; GENOVESE, 2007; SOUSA et al., 2010)

A tecnologia dos lasers está presente em uma variedade de aplicações: telecomunicações por fibras óticas, leitura e gravação de dados em CDs, na medicina, odontologia, sendo que estas são apenas algumas que podem ser mencionadas.

Nas aplicações para a ciência da vida, os raios laser dividem-se em grupos, de acordo com a sua potência, sendo eles: de alta potência, também chamados de laser cirúrgico, laser de alta intensidade (LAl), laser quente, laser duro ou "hard laser" e os de baixa potência, também chamados de laser em baixa intensidade (LBI), laser frio, laser terapêutico (LT), laser mole ou soft-laser e o laser de média intensidade ou mid-laser, que emitem radiações com potências medianas, sem poder destrutivo, sendo mais utilizados em fisioterapia (RYDEN; BJELKHAGEN; SODER, 1975; MATEOS, 2005; SOUSA et al., 2010).

Os lasers de alta intensidade (LAl) ou laser de alta potência ou cirúrgicos servem para cortar, esterilizar, coagular e vaporizar os tecidos moles ou duros. A radiação do laser de alta potência interage com os tecidos basicamente por reações fototérmicas, nas quais a energia da luz absorvida pelos tecidos é transformada em calor (LIZARELLI, 2007; PINHEIRO; BRUGNERA; ZANIN, 2010).

Os lasers de baixa intensidade (LBI) emitem radiações de baixas potências, com energia menores que 2,0 elétron-volt $(\mathrm{eV})$, portanto, inferior à energia da ligação das moléculas biológicas e do DNA, de maneira a não promover quebras das ligações químicas e não induzir mutação e carcinogênese (BRUGNERA; GENOVESE; VILLA, 1991). Possuem uma ação analgésica, antiinflamatória (RYDEN; BJELKHAGEN; SODER, 1975; THEODORO et al., 2001; MATEOS, 2005; SOUSA et al., 2010) ou de biomodulação ou fotobiomodulação tecidual (estimulação ou inibição) (LIM; LEW; TAY, 1995; TURHANI et al., 2006; SOUSA et al., 2010; ANGELIERI et al., 2011) e dá-se o nome de laserterapia (LT) ao tratamento 
realizado por meio desta luz (LBI). Entre os lasers de baixa potência encontram-se os lasers de He-Ne (Hélio-Neônio) e diodo (Arseneto de gálio - AsGa e Arseneto de gálio e alumínio - AsGaAl).

$\mathrm{Na}$ Ortodontia, a laserterapia tem demonstrado ser eficiente na analgesia (LIM; LEW; TAY, 1995; TURHANI, et al., 2006; YOUSSEF, et al., 2008; TORTAMANO, et al., 2009; ARTÉS-RIBAS; ARNABAT-DOMINGUEZ; PUIGDOLLERS, 2012) além de proporcionar de uma forma mais rápida, a reabsorção e neoformação ósseas necessárias para a movimentação dentária induzida ortodonticamente, abreviando o tempo de tratamento (CRUZ et al., 2004; LIMPANICHKUL, et al., 2006; YOUSSEF, et al., 2008; CAMACHO; CUJAR, 2010; SOUSA et al., 2011; DOSHI-MEHTA; BHAD-PATIL, 2012; GENC et al., 2012), porém há apenas dois trabalhos na literatura (GOULART et al., 2006; SEIFI et al., 2007) em animais, no qual foi observado que com dosimetrias mais elevadas, há uma inibição da movimentação ortodôntica.

Este efeito de inibição é de grande importância quando se deseja a preservação da ancoragem favorecendo a mecânica ortodôntica, que tem sido considerada por muitos ortodontistas um dos fatores limitantes no tratamento e seu controle decisivo para uma correta finalização (THIRUVENKATACHARI et al., 2006; BENSON et al., 2007; ARAÚJO et al., 2012). Além disso, os dispositivos existentes para este propósito, ou dependem da colaboração do paciente, como no caso dos aparelhos extrabucais, ou causam algum desconforto, como no caso dos dispositivos intrabucais.

Em decorrência da inexistência de ensaio clínico em humanos, utilizando-se a laserterapia com o propósito de inibição da movimentação ortodôntica de maneira a favorecer a ancoragem, objetivar-se-á neste estudo avaliar a influência do laser em baixa intensidade no bloqueio desta movimentação bem como na inibição da sensibilidade dolorosa provocada pela ativação do aparelho ortodôntico com a verificação da preservação da integridade dos tecidos periodontais. 



\section{Revísão da líteratura}

"A imaginação é mais importante que a ciência, porque a ciência é limitada, ao passo que a imaginação abrange o mundo inteiro."

Albert Einstein 



\section{REVISÃO DA LITERATURA}

A revisão de literatura foi dividida em quatro partes distintas para um melhor entendimento:

2.1 - Força ortodôntica e reações celulares, moleculares e teciduais;

2.2 - Terapia com laser em baixa intensidade em Ortodontia: efeitos na movimentação dentária induzida ortodonticamente e na modulação da dor;

2.3 - Ancoragem ortodôntica;

2.4 - Tomografia computadorizada feixe cônico.

\subsection{Força ortodôntica e reações celulares, moleculares e teciduais}

O tratamento ortodôntico é baseado no princípio de que uma pressão prolongada sendo aplicada em um dente resultará no seu deslocamento.

O movimento dentário obtido por aplicação de força é caracterizado por alterações que remodelam os tecidos dentários e periodontais, incluindo a polpa dentária, ligamento periodontal (LP), osso alveolar e gengiva. Esses tecidos, quando expostos a diferentes graus de magnitude, freqüência e duração de força expressam extensas alterações micro e macroscópicas (KRISHNAN; DAVIDOVITCH, 2006; ARIFFIN et al., 2011). Além disso, a aplicação de forças sobre o dente, coloca as células do ligamento periodontal em estresse, elevando o nível local de numerosos mediadores indutores de vários fenômenos de natureza celular, tecidual e/ou vascular, dentre os quais os indutores da reabsorção e da neoformação óssea (CONSOLARO, 2012).

O movimento dentário ortodôntico é caracterizado pela criação de regiões de tração e compressão no ligamento periodontal, que podem ocorrer rapidamente ou lentamente, dependendo das características físicas da força aplicada e da quantidade da resposta biológica do ligamento periodontal (CONSOLARO, 2012). 
Tradicionalmente, as forças ortodônticas têm sido classificadas como leves ou pesadas, e acreditava-se que as forças leves fossem mais fisiológicas que as pesadas. No entanto, Burstone (1962 apud KRISHNAN; DAVIDOVITCH, 2006), reportaram que forças ortodônticas nunca são distribuídas igualmente através do ligamento periodontal e Storey (1973), observaram que um pouco de trauma sempre está presente quando há forças ortodônticas aplicadas, mesmo que leves.

Storey e Smith (1952), estudando o movimento ortodôntico distal dos caninos, sugeriram que há uma variação ideal de força (150 a 200g) na interface do osso alveolar com o ligamento periodontal a qual produz uma quantidade máxima de movimento dentário. Uma pressão abaixo dessa taxa não promoveu movimento do dente, e com uma força acima da ideal, a taxa de movimento dentário decresceu e chegou à zero em uma semana e Reitan (1964,1974), em seus clássicos estudos, definiu a força ótima como uma força apenas suficiente para aumentar a atividade celular nos tecidos circundantes ao elemento dentário e permitir movimento, reduzindo o risco de reabsorção radicular.

Segundo Mao, Wang e Kopher (2003), a mecanoterapia ortodôntica tem como principal objetivo o movimento do dente por meio de alterações adaptativas e remodelações nos tecidos periodontais. Para se conseguir isso, uma força suave, de 20 a $150 \mathrm{~g}$ por dente é suficiente. O conceito atual de força ideal consiste num estímulo mecânico extrínseco, que evoca uma resposta celular que objetiva restaurar o equilíbrio da área por meio da remodelação periodontal. Logo, a carga mecânica que leva ao máximo movimento dentário com risco mínimo aos tecidos dentários, ao ligamento periodontal e ao osso alveolar, é considerada ideal. Esse conceito significa que há uma força de certa magnitude e características temporais, capaz de produzir um máximo movimento dentário, sem prejuízo aos tecidos, e com máximo conforto para o paciente. De acordo com esse conceito, a força ideal pode ser diferente para cada dente e para cada paciente. Clinicamente, a relação entre a magnitude de força ortodôntica e o nível de movimento dentário obtido durante o tratamento ativo, deve ser considerada como um método prático na identificação da força ideal para cada indivíduo (REN; MALTHA; KUIJPERS-JAGTMAN, 2003).

As forças ortodônticas aplicadas sobre os dentes são transmitidas às células e resultam em eventos biológicos reacionais ou adaptativos. No movimento dentário induzido, desenvolve-se um processo inflamatório cujo objetivo é eliminar o agente agressor, que neste caso é a força, dissipando-a no ligamento periodontal. Assim 
sendo, este promove a reabsorção óssea frontal, com alargamento local do espaço periodontal e perda da ação do agente agressor (KRISHNAN; DAVIDOVITCH, 2006; CONSOLARO, 2012).

Dentre os fatores que influenciam o mecanismo da movimentação dentária, destacam-se: a reação inflamatória provocada pela injúria aos tecidos do ligamento periodontal, a liberação de prostaglandina, em decorrência da deflexão óssea e o efeito piezoelétrico do tecido ósseo.

\section{Reação inflamatória:}

Em 1962, Burstone (apud KRISHNAN; DAVIDOVITCH, 2006), sugeriu três fases do movimento dentário: uma inicial, caracterizada por um movimento rápido, atribuída ao deslocamento do dente no espaço do ligamento periodontal; a segunda fase lenta, com taxas relativamente baixas ou de nenhuma movimentação dentária, produzida por hialinização do ligamento periodontal em áreas de compressão e a terceira fase, onde a taxa de movimentação sobe gradualmente no decorrer do tempo. Essa terceira fase só é iniciada quando, na segunda fase, ocorrer a remoção de todos os tecidos necróticos presentes.

Segundo Krishnan e Davidovitch (2006), as alterações na remodelação dos tecidos periodontais são consideradas essenciais para o movimento dentário ortodôntico. O estiramento tecidual produz alterações locais na vascularidade bem como na reorganização de matrizes celulares e extracelulares, levando à síntese e liberação de vários neurotransmissores, citocinas, fatores de crescimento, fatores estimuladores de colônias (relacionados aos granulócitos, macrófagos e outros tipos celulares relacionados à remodelação óssea) e metabólitos do ácido araquidônico. Reações celulares e moleculares em resposta às forças ortodônticas são as bases biológicas do movimento dentário induzido.

A fase inicial do movimento dentário ortodôntico sempre envolve resposta inflamatória aguda, caracterizada por vasodilatação periodontal e migração de leucócitos dos capilares sanguíneos. Como qualquer outro agente, uma força aplicada no ligamento periodontal promove diretamente a compressão ou estresse mecânico das células e pode gerar proteínas livres no meio intersticial por destruição eventual de algumas células. O colabamento dos vasos sanguíneos pela pressão exercida promove hipóxia ou anóxia, e também pode gerar proteínas livres, decorrentes da destruição ou da desorganização de fibras colágenas e da matriz 
extracelular. Essas proteínas liberadas fazem com que os mastócitos do ligamento periodontal degranulem, liberando histamina e promovendo ainda a síntese de neuropeptídeos pelas terminações nervosas livres. Esses dois fenômenos desencadeiam a contração das células endotelias e em consequência, acontece a vasodilatação e o aumento da permeabilidade vascular, estabelecendo-se a exsudação plasmática (KRISHNAN; DAVIDOVITCH, 2006; CONSOLARO, 2012).

Esta fase se dá aproximadamente 90 minutos após a aplicação de uma força no ligamento periodontal, estando caracterizado o início do estabelecimento do infiltrado inflamatório (CONSOLARO, 2002).

Essas células migratórias, principalmente os macrófagos, são encontrados em maior número no espaço intersticial entre 24 a 72 horas. Enquanto fagocitam as proteínas desnaturadas e tecido necrótico são grandes produtores de substâncias para o meio extracelular, como as citocinas, fatores de crescimento e produtos do ácido araquidônico, como por exemplo, prostaglandinas, além de outros mediadores importantes. Esses mediadores exercem quimiotaxia para as células mesenquimais, células endoteliais, fibroblastos e osteoblastos, efetivando também estímulos à proliferação e síntese por parte dessas células, remodelando os tecidos periodontais e facilitando o movimento dentário (INTERLANDI, 1999; CONSOLARO, 2002).

O processo inflamatório agudo que define a fase inicial do movimento dentário ortodôntico é predominantemente exsudativo, no qual o plasma e leucócitos deixam os capilares em áreas do ligamento periodontal (LP). Um ou dois dias depois, a fase aguda da inflamação é substituída por um processo crônico que é principalmente proliferativo, envolvendo fibroblastos, células endoteliais, osteoblastos (KRISHNAN; DAVIDOVITCH, 2006), e células osteoprogenitoras* (INTERLANDI, 1999).

A inflamação crônica prevalece até o próximo encontro clínico, quando o ortodontista ativa o aparelho, assim iniciando outro período de inflamação aguda, superpondo-a à inflamação crônica que está acontecendo. Para o paciente, os períodos de inflamação aguda são associados com sensações dolorosas e função matigatória reduzida. Um reflexo desses fenômenos pode ser encontrado no fluído

\footnotetext{
* É também chamada de célula de revestimento ósseo, sendo considerada como uma célula de repouso ou também célula de reserva. Esta célula, quando estimulada, se transforma em osteoblasto e produz matriz óssea. As células osteoprogenitoras são encontradas nas superfícies dos ossos em crescimento e também naqueles ossos que estão sofrendo uma remodelação. Portanto ela representa uma população de células que se localiza numa camada mais interna do periósteo. Essas células também representam células endósteas, ou seja, células que revestem as cavidades do osso esponjoso e também a cavidade da medula óssea dos ossos longos.
} 
gengival (FG) dos dentes em movimento, onde elevações significantes nas concentrações de mediadores inflamatórios, tais como citocinas e prostaglandinas, ocorrem temporariamente (KRISHNAN; DAVIDOVITCH, 2006).

\section{Liberação de prostaglandinas:}

O valor do FG na avaliação do estado biológico dos tecidos localizados no periodonto permite que seja uma fonte de biomarcadores de situações clínicas específicas. Este dado é de grande valia no monitoramento da eficiência e resultados do tratamento ortodôntico, pois se sabe que as substâncias envolvidas na remodelação óssea são produzidas pelas células do ligamento periodontal, em quantidades suficientes para serem difundidas dentro do fluido gengival (YAMASAKI et al., 1984; LEE, 1990), particularmente a prostaglandina PGE2 que tem sido relatada como um potente mediador da reação inflamatória causada pela movimentação dentária induzida (GRIEVE et al., 1994).

Yamasaki et al (1984), após a injeção local de prostaglandinas em roedores, verificaram um aumento do número de osteoclastos e horas depois da administração de endometacina, um agente antiinflamatório e inibidor específico da síntese de prostaglandinas, observaram uma redução na taxa de movimentação dentária.

Lee (1990), num estudo clínico feito em animais, identificou o papel das prostaglandinas (PGE1 e PGE2) no estímulo da reabsorção óssea. Prostaglandinas foram administradas localmente e sistemicamente em ratos para avaliação da eficácia entre os dois métodos de administração. Os resultados demonstraram que no grupo em que as prostaglandinas foram administradas sistemicamente, houve menor quantidade de movimentação quando comparado ao grupo em que houve a administração local, porém, quando comparado ao grupo controle, os dois grupos que receberam a droga apresentaram maior movimentação dentária. Ele reportou uma ação direta das prostaglandinas nos osteoclastos, aumentando seu número e sua capacidade de formar a "borda em escova" e causar a reabsorção óssea.

A PGE2 também estimula a diferenciação da célula osteoblástica, promovendo neoformação óssea (KRISHNAN; DAVIDOVITCH, 2006) como também produz um aumento da permeabilidade e dilatação dos vasos sanguíneos (GRIEVE et al., 1994). 


\section{Piezoeletricidade}

Associados aos fenômenos biológicos, outro fator físico-químico está envolvido na movimentação ortodôntica: a piezoeletricidade.

Piezoeletricidade é um fenômeno observado em muitos materiais cristalinos, em que uma deformação de uma estrutura cristalina produz fluxo de corrente elétrica quando elétrons são deslocados de uma parte da eletrosfera para outra (KRISHNAN; DAVIDOVITCH, 2006). No caso do tecido ósseo, cristais de hidroxiapatita, por compressão ou tração podem gerar modificações eletromagnéticas ao seu redor. Essas modificações promovem estímulos ao estresse nas células da região periodontal e óssea, acumulando-se mediadores da remodelação óssea na interface periodontal (CONSOLARO, 2002). Em áreas eletronegativas ocorrem a formação de osso com elevada atividade osteoblástica e em áreas eletropositivas ocorrem reabsorções ósseas evidenciando-se elevada atividade osteoclástica (MOSTAFA; WEAKS-DYBVIG; OSDOBY, 1983).

Davidovitch et al (1980), investigaram a remodelação óssea na movimentação ortodôntica por meio das correntes elétricas, em que as ativações celulares ocorrem dentro ou através da membrana celular e envolvem fluxo de íons como $\mathrm{Ca}^{2+}, \mathrm{Mg}^{2+}$, $\mathrm{Na}^{+}, \mathrm{K}^{+}, \mathrm{Cl}^{-}$e fosfato inorgânico, assim como as ativações na membrana por meio de enzimas como a adenilato ciclase e guanilato ciclase. Na membrana, essas enzimas têm efeito sobre seus respectivos substratos: adenosina trifosfato (ATP) e guanosina trifosfato (GTP) para produzir adenosina, 3', 5'- monofosfato (AMP cíclico, cAMP) e guanosina 3', 5' - monofosfato (GMP cíclico, cGMP). Estas últimas substâncias, junto com o $\mathrm{Ca}^{2+}$, são conhecidas como "mensageiros secundários intracelulares", desencadeando reações fosforilativas, levando à resposta celular. Essa resposta pode consistir em motilidade, contração, proliferação, síntese e secreção celulares.

A figura 1 representa os eventos desencadeados em resposta à aplicação de uma força ortodôntica (MOSTAFA; WEAKS-DYBVIG; OSDOBY, 1983). 


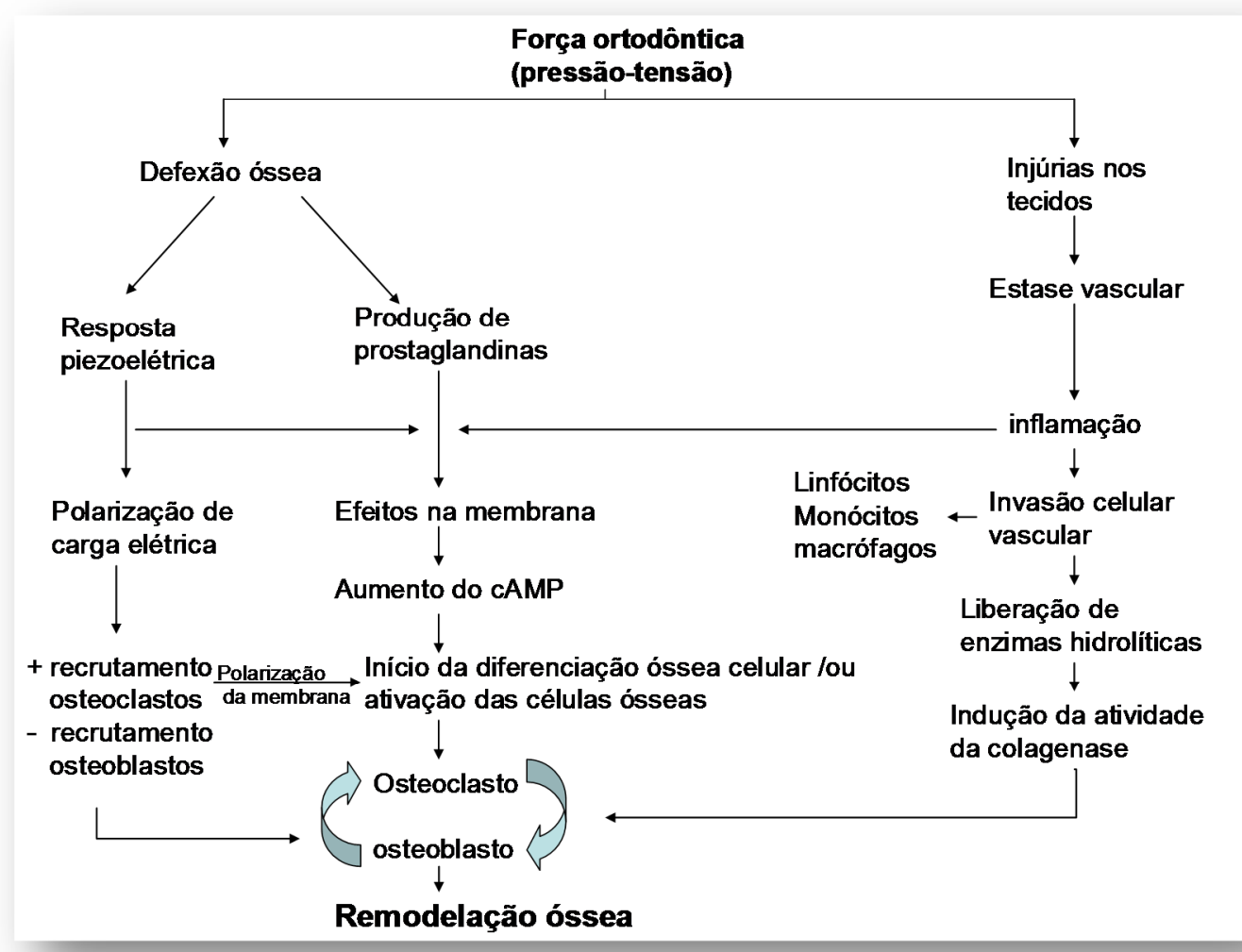

Figura 1 - Sequência de eventos que ocorrem pela aplicação de uma força ortodôntica (MOSTAFA; WEAKS-DYBVIG; OSDOBY, 1983).

\subsection{Terapia com laser em baixa intensidade em Ortodontia}

\subsubsection{Efeitos do laser em baixa intensidade na estimulação da} movimentação ortodôntica com enfoque celular e estudos em animais.

Além da dor pós-ativação ortodôntica, uma das grandes queixas dos pacientes que se submetem ao tratamento ortodôntico é o tempo prolongado de tratamento.

$\mathrm{Na}$ literatura encontramos vários recursos que tentam promover uma movimentação dentária mais rápida e desta forma, minimizar o tempo de tratamento. Alguns estudos têm demonstrado que a aceleração da movimentação dentária pode ser produzida por meio da injeção local de prostaglandinas (YAMASAKI et al., 1984), ou de 1,25 (OH)2D3 (a forma ativa da vitamina D) (COLLINS; SINCLAIR, 1988; TAKANO-YAMAMOTO et al., 1992) e osteocalcina (KOBAYASHI et al., 1998), que é 
uma proteína produzida exclusivamente pelos osteoblastos durante o processo da síntese da matriz óssea (LIMPANICHKUL et al., 2006).

A aplicação local de corrente elétrica (DAVIDOVITCH et al., 1980), o uso local de hormônio da paratireoide (paratormônio - PTH) (SOMA et al., 2000) e a aplicação do ultrassom (PRIETO; DAINESI; KAWAUCHI, 2005; EL-BIALY et al., 2011) também são recursos que tem demonstrado acelerar a movimentação dentária.

Todavia, todas essas substâncias injetáveis citadas, bem como a aplicação de corrente elétrica e ultrassom, embora demonstrem acelerar a velocidade de movimentação dentária, também causam efeitos colaterais como dor e desconforto ao paciente (CRUZ et al., 2004; LIMPANICHKUL et al., 2006; SOUSA et al., 2011).

A Laserterapia (LT) é uma ampla fonte de pesquisa nas mais diversas áreas da saúde, uma vez que os efeitos dessa terapia são dose dependente e a ação desta radiação nos diferentes tecidos biológicos e nas diversas patologias ainda não está bem esclarecida, mas alguns pontos já foram elucidados.

Já é de conhecimento que por meio das aplicações de LBI e dependendo do comprimento de onda utilizado (infravermelho próximo ou vermelho visível), a energia é transmitida diretamente para as mitocôndrias (vermelho visível: 630 a 700nm) ou para a membrana celular (infravermelho: 700 a 904nm). Independentemente do sítio de absorção, esta energia é absorvida pelos cromóforos $^{*}$ intracelulares e convertida em energia metabólica (ver apêndice).

A ponteira do laser com o seu comprimento de onda é escolhida em conformidade com o tecido alvo e o efeito desejado. O melhor comprimento de onda para bioestimulação é entre 550 e 950nm. Como a absorção do infravermelho é menor para a hemoglobina do que o vermelho visível, então, o laser que emite luz no infravermelho (700 a $904 \mathrm{~nm}$ ) é o melhor comprimento de onda para estimular as células ósseas pelo fato de penetrar mais profundamente no tecido através do tecido mole, atingindo o tecido ósseo (WAN; ANDERSON; PARRISH, 1981; KOLA'ROVA'; DITRICHOVA'; WAGNER, 1999; STOLIK et al., 2011).

Com o comprimento de onda na faixa do infravermelho observa-se um maior número de íons de $\mathbf{C a}++$ no citoplasma com um aumento da permeabilidade da membrana celular devido às alterações do potencial de membrana (bomba de sódio-potássio). Isto promove aumento da síntese proteica, acelerando a duplicação de DNA, replicação de RNA e/ou aceleração do metabolismo celular. A mesma resposta final ocorre com o comprimento de onda no vermelho 
visível, pois a cadeia respiratória mitocondrial é ativada, resultando no início de uma cascata que promove a sinalização celular e aumento de produção de ATP (KARU, 1988).

Não se sabe ao certo quais são e quantos são os cromóforos que absorvem o comprimento de onda da luz laser, porém a literatura descreve alguns fotorreceptores já identificados, como por exemplo, a melanina, a hemoglobina, a oxihemoglobina e mais especificamente um receptor da membrana mitocondrial que interage com a luz laser: o citocromo c oxidase* e a NADH-desidrogenase* (KARU, 1987)

Karu (1999) já verificava em seus experimentos, que um dos possíveis fotorreceptores seria o citocromo c oxidase presente na membrana mitocondrial, fato este confirmado posteriormente em seu trabalho em 2005 (KARU, 2005) e mais recentemente por Wu et al (2010), que observaram os efeitos do laser em baixa intensidade em mastócitos e quais os fatores envolvidos na liberação de histaminas por meio de sondas de fluorescência e constataram que o citocromo c oxidase comporta-se como um fotorreceptor. Eles absorvem os fótons (ver apêndice) incidentes iniciando a sinalização mitocondrial, havendo abertura dos canais de cálcio da membrana, aumentando a $\mathrm{Ca}+$ intracelular e consequentemente a liberação de histaminas pelos mastócitos.

A bioestimulação promovida pela LT, em alguns comprimentos de onda na faixa do vermelho visível (ver apêndice), promovem na mitocôndria o aparecimento de uma espécie reativa de oxigênio (ROS) e Ca++ mitocondrial, o que aumenta a formação de trifosfato de adenosina (ATP) no ponto irradiado e o metabolismo celular é acelerado (KARU, 2008; TAFUR; MILLS, 2008; WU et al., 2010).

Sabe-se que o ROS produzido em grandes quantidades tem consequências destrutivas para a célula, porém em pequenas quantidades, podem atuar como mensageiros secundários induzindo a diferenciação celular (MOTTA, 2003).

O efeito do LBI na membrana celular (comprimento de onda do infravermelho) (ver apêndice) está relacionado com a interação da luz laser com as ATPases que

\footnotetext{
cromóforos, ou também denominados fotorreceptores consistem em um grupo de moléculas interrelacionadas que podem ser enzimas, membranas celulares ou quaisquer outras substâncias intra ou extracelulares que apresentem a capacidade de absorver luz num determinado comprimento de onda, mas não são especializadas para isto.

* citocromo c oxidase e NADH-desidrogenase: são complexos proteicos que participam do transporte de elétrons na membrana interna da mitocôndria. Este transporte de elétrons gera um aumento do $\mathrm{H}_{+}$ no espaço intramembranar. $\mathrm{O}$ fluxo de $\mathrm{H}_{+}$para dentro da matriz mitocondrial move a enzima ATPsintase, gerando energia suficiente para síntese de ATP.
} 
são enzimas encontradas na membrana celular e dentre elas a mais importante é a Na+/K+-ATPase (KASSÁK et al., 2006) ou bomba de Na+ e K+. Com a mudança na bomba de sódio e potássio, há um aumento da permeabilidade aos íons Ca++ para o meio intracelular que afetam o nível dos nucleotídeos cíclicos que modulam a síntese de RNA e DNA (KARU et al., 1984). A entrada de Ca++ para o meio intracelular também permite a ativação de diversos processos metabólicos dependendo da função específica de cada célula, por exemplo, em osteoblastos a presença de $\mathrm{Ca}++$ intracelular ocasiona um maior estímulo para a produção de fosfatase alcalina e/ou osteocalcina e consequentemente uma maior formação de tecido ósseo.

Durante a formação do osso, a produção da matriz colágena ocorre antes da mineralização, ou seja, primeiro o organismo faz a forma depois deposita o concreto. A fase de produção de matriz colágena (fase em que o organismo esta fazendo a forma) coincide com uma maior produção de fosfatase alcalina, enquanto a mineralização (colocação do concreto) coincide com uma maior produção de osteocalcina.

$\mathrm{Na}$ literatura há inúmeros trabalhos in vitro que comprovam o aumento do Ca++ intracelular (BREITBART et al., 1996; COOMBE et al., 2001; SARACINO et al., 2009) e outros que demonstram a proliferação de osteoclastos (AIHARA; YAMAGUCHI; KASAI, 2006; YAMAGUCHI et al., 2007; YAMAGUCHI et al., 2010) e osteoblastos (OZAWA et al., 1998; DORTBUDAK; HASS; MAILATH-POKORNY, 2000; UEDA; SHIMIZU, 2001; FUJIHARA; HIRAKI; MARQUES, 2006; SHIMIZU et al., 2007; OLIVEIRA et al., 2008; DOMINGUEZ; CASTRO; MORALES, 2009) após a irradiação com LBI. Outros trabalhos avaliaram a atividade da fosfatase alcalina (OZAWA et al., 1998; UEDA; SHIMIZU, 2001; XU et al., 2009) e da osteocalcina (OZAWA et al., 1998) com a irradiação laser. A maioria dos trabalhos revelou um aumento tanto da atividade da fosfatase alcalina óssea como da osteocalcina com a influência do LBI, refletindo numa maior formação óssea.

Outro possível efeito do LBI no processo de neoformação e reabsorção óssea relatado recentemente na literatura é a ativação de osteoclastos via RANKL. Para que se possa entender esta via de ativação, são necessárias algumas explicações prévias:

Os osteoblastos são derivados das células osteoprogenitoras e são responsáveis pela síntese dos componentes orgânicos protéicos e glicídios da 
matriz óssea. Adicionalmente produzem RANKL (receptor de ativação do fator nuclear kappa B ligante) (GARTNER; HIATT, 2007) que é uma citocina essencial para a indução da osteoclastogênese (ANDIA; CERRI; SPOLIDORIO, 2006). Os osteoclastos, por outro lado, são derivados das células hematopoiéticas (monocíticas ou macrofágicas) e degradam a matriz óssea. Existe comunicação entre os osteoblastos e os osteoclastos, onde os osteoblastos regulam a atividade dos osteoclastos. RANKL (produzido pelo osteoblasto) liga-se a um receptor chamado RANK, que está localizado na superfície dos osteoclastos e dos precursores dos osteoclastos. A ligação do RANKL ao RANK induz osteoclastogênese, ativa os osteoclastos maduros, media a inserção no osso, e promove a sua sobrevivência. A atividade de RANKL é controlada por um receptor chamariz solúvel chamada osteoprotegerina (OPG), que regula negativamente a formação e ativação dos osteoclastos, interrompendo a ligação RANK/RANKL, inibindo a formação de osteoclastos, ativação e sobrevida (ANDIA; CERRI; SPOLIDORIO, 2006). OPG é uma proteína secretada pelos osteoblastos que inibem a atividade e diferenciação dos osteoclastos (YAMAGUCHI, 2009).

Aihara, Yamaguchi e Kasai (2006) avaliaram os efeitos do LBI na ativação dos osteoclastos via RANKL e observaram um aumento da expressão RANK/RANKL/OPG e consequentemente uma maior ativação e diferenciação de osteoclastos e Kim et al (KIM et al., 2007) avaliaram em ratos a presença do sistema RANK/RANKL/OPG em implantes de titânio após laserterapia e concluíram que o LBI além de influenciar a expressão RANK/RANKL/OPG, resultou numa expansão da atividade metabólica das células do tecido ósseo.

A figura 2 resume os principais mecanismos de ação do laser em baixa intensidade e sua interação com os componentes celulares resultando na ativação do metabolismo celular. 


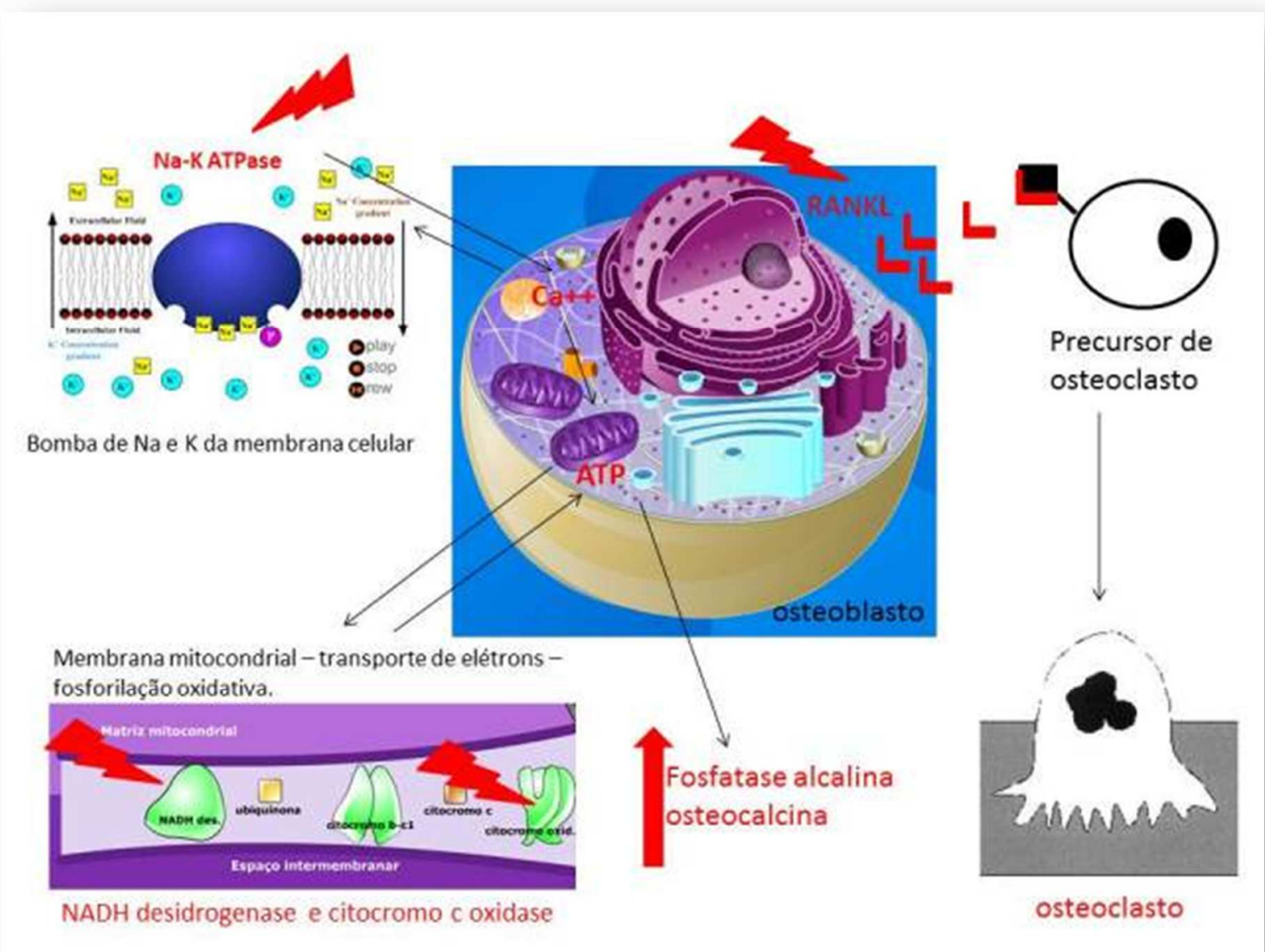

Figura 2. Principais eventos celulares desencadeados após a laserterapia em osteoblastos (Fonte: esquema feito pela aluna MVSS com imagens de diversos sites)

Há alguns trabalhos em animais que demonstram os efeitos do LBI influenciando a aceleração da movimentação ortodôntica (YAMAGUCHI et al., 2007; FUJITA et al., 2008; YOSHIDA et al., 2009; KIM et al., 2010; YAMAGUCHI et al., 2010).

Um dos primeiros trabalhos publicados foi o de Kawasaki e Shimizu (2000). Eles utilizaram um total de 24 ratos que foram divididos em dois grupos de 12 ratos cada, onde o primeiro grupo foi irradiado e o segundo grupo, não irradiado. Foram instaladas molas de aço para movimentação mesial dos primeiros molares superiores esquerdos liberando uma força de $10 \mathrm{~g}$. A movimentação foi acompanhada por 13 dias. As distâncias foram mensuradas utilizando-se modelos obtidos nos dias $0,1,2,4$ e 12. A quantidade de movimentação dentária foi determinada pela diferença das medidas entre as cúspides mésio-vestibulares dos primeiros e segundos molares esquerdos antes (dia 0) e após a movimentação 
dentária (dias 1, 2, 4 e 12). O protocolo de aplicação foi: comprimento de onda (ver apêndice) de 830nm, potência (ver apêndice) de $100 \mathrm{~mW}$ por 3 minutos em cada ponto, num total de 3 pontos uma vez ao dia por 12 dias. O total de energia correspondente a 9 minutos de exposição foi de $54 \mathrm{~J}$ (18J por ponto). Para verificação da quantidade de osso depositado, injeções de calceína foram administradas nos dias $0,4,8$ e 12 . No $13^{\circ}$ dia os ratos foram sacrificados para análise histológica e histomorfométrica do tecido ósseo. Os autores concluíram que o laser em baixa intensidade (Ga-Al-As diodo), com comprimento de onda de 830 $\mathrm{nm}$, aplicado no protocolo acima relatado, causou a aceleração da remodelação óssea em ratos Wistar e pode ter grande benefício no tratamento ortodôntico. Segundo os autores, o laser estimula a proliferação celular e a diferenciação de linhagens de osteoblastos, resultando no aumento da formação óssea.

\subsubsection{Efeitos do laser em baixa intensidade na inibição da movimentação} ortodôntica com enfoque celular e estudos em animais.

Karu (1990), com base em seus estudos experimentais em organismos unicelulares, já afirmava que os efeitos do LBI no tecido biológico são dosedependente e comprimento de onda-dependente. Chamava também a atenção dos pesquisadores, observando que cada tipo de linhagem de célula poderia ter um efeito distinto caso houvesse variação de comprimento de onda e da dose de energia recebida, passando da estimulação do metabolismo celular para a inibição.

Este fato foi observado no estudo de Haxsen et al. (2008) em culturas de osteoblastos humanos com características fenotípicas diferentes: culturas primárias de osteoblastos e osteosarcomas, onde foram realizadas aplicações de LBI com diferentes densidades de potência (DP) (ver apêndice). Neste estudo foi avaliada a atividade da fosfatase alcalina e constatou-se que com altas doses de radiação com LBI em osteosarcomas, há uma redução da atividade celular (em torno de $20 \%$ ), enquanto que baixas doses de radiação há um aumento da atividade celular (em torno de $40 \%$ ). Observou-se também que os osteoblastos primários responderam de maneira diferente em relação ao osteosarcoma. Para os osteoblastos, duplicando-se a densidade de potência $\left(51 \mathrm{~mW} / \mathrm{cm}^{2}\right.$ para $\left.102 \mathrm{~mW} / \mathrm{cm}^{2}\right)$ não houve alteração da atividade da fosfatase alcalina, somente com um aumento de densidade de potência 
de 4 vezes em relação à primeira dose $\left(\right.$ de $51 \mathrm{mw} / \mathrm{cm}^{2}$ para $\left.204 \mathrm{~mW} / \mathrm{cm}^{2}\right)$ observouse uma aumento significante.

Renno et al. (2007), demonstraram que não somente a densidade de energia DE (ver apêndice) influencia na resposta celular, como também o comprimento de onda (ver apêndice). Neste estudo foram utilizados três comprimentos de ondas: $830 \mathrm{~nm}, 780 \mathrm{~nm}$ e $670 \mathrm{~nm}$, com densidades de energia variáveis: $0,5 \mathrm{~J} / \mathrm{cm}^{2}, 1 \mathrm{~J} / \mathrm{cm}^{2}$, $5 \mathrm{~J} / \mathrm{cm}^{2}$ e $10 \mathrm{~J} / \mathrm{cm}^{2}$ em osteoblastos e osteosarcomas. Os autores observaram que com o comprimento de onda de $780 \mathrm{~nm}$ a partir da dose de $1 \mathrm{~J} / \mathrm{cm}^{2}$, houve uma diminuição estatisticamente significante da proliferação de osteoblastos comparado com o grupo controle, apesar de não se ter detectado diferenças na atividade de fosfatase alcalina, enquanto que para osteosarcomas, com os mesmos parâmetros em relação à dosimetria (ver apêndice), o efeito foi inverso, ou seja, houve uma estimulação da proliferação celular.

Outro dado importante foi relatado no experimento de Xu et al. (2009) em pesquisas com osteoblastos. Eles observaram que o grupo de células irradiadas com $1,14 \mathrm{~J} / \mathrm{cm}^{2}$ de densidade de energia, houve um aumento da expressão de OPG (inibidor de osteoclastos) e uma inibição da expressão de RANKL (ativador de osteoclastos) em relação ao grupo controle. Além disso, houve um aumento da fosfatase alcalina (marcador de osteoblastos) nas células irradiadas em relação ao grupo controle. Isto significa que esta dose, in vitro, inibiu a diferenciação de osteoclastos, porém aumentou a atividade metabólica e proliferação de osteoblastos, sugerindo ser de grande valia para tratamento em pacientes portadores de osteoporose.

$\mathrm{Na}$ literatura, alguns estudos em animais tiveram efeito de retardo na movimentação ortodôntica. O primeiro estudo publicado com este resultado foi o de Goulart et al. (2006).

Goulart et al.(2006), num estudo experimental em cães, avaliaram a velocidade de movimentação dentária dos primeiros molares e segundos prémolares irradiados com LBI, tendo os contralaterais como placebo. Utilizaram dois grupos de cães: o grupo I, recebeu uma dose de $5,25 \mathrm{~J} / \mathrm{cm}^{2}$ (energia de $70 \mathrm{~mW}$, durante 3 segundos, total de energia de $0,21 \mathrm{~J}$ ) na área alveolar correspondente ao terço médio da raiz distal do segundo pré-molar, enquanto o grupo II, recebeu uma dosagem de $35 \mathrm{~J} / \mathrm{cm}^{2}$ (energia de $70 \mathrm{~mW}$ durante 20 segundos, total de energia de $1,4 \mathrm{~J}$ ). As irradiações eram feitas a cada sete dias, num total de nove 
irradiações. A distância entre os segundos pré-molares e primeiros molares foi medida a cada 21 dias e os resultados encontrados demonstraram que o laser pode acelerar a movimentação ortodôntica, quando aplicado numa dosagem de $\mathbf{5 , 2 5} \mathrm{J} / \mathrm{cm}^{2}$. Contudo, dosagens altas, de $35 \mathrm{~J} / \mathrm{cm}^{2}$, por exemplo, pode retardá-la.

Seifi et al (2007), num estudo em coelhos, comparou dois comprimentos de ondas: 850nm e 630nm e as suas influências sobre a quantidade de movimentação ortodôntica. Neste estudo experimental foram utilizados 18 coelhos albinos machos divididos em 3 grupos: grupo controle, grupo 850nm e grupo 630nm. Molas fechadas de $\mathrm{NiTi}$, liberando uma força de aproximadamente 100/120 gramas/força foram instaladas nos primeiros molares. O grupo controle não foi irradiado, enquanto que os grupos lasers receberam doses no intervalo de 9 dias. $O$ grupo $850 \mathrm{~nm}$ recebeu uma dosagem de $\mathbf{8 , 1} \mathbf{J}$ de energia por dia $(P=5 \mathrm{~mW})$ com um ponto de aplicação e duração de 3 minutos, gerando $72,9 \mathrm{~J}$ de energia mensal, enquanto que o grupo 630 $\mathrm{nm}$ recebeu uma dosagem de $27 \mathbf{J}$ de energia por dia $(\mathbf{P}=\mathbf{1 0} \mathbf{m W}$ ), com um ponto de aplicação e duração de 5 minutos, gerando 243J de energia mensal. Após 16 dias, a distância entre a distal do primeiro molar e mesial do segundo molar foi mensurada com um paquímetro digital nos 3 grupos. Os resultados da análise macroscópica demostraram uma diminuição da movimentação ortodôntica nos grupos $850 \mathrm{~nm}$ e $630 \mathrm{~nm}$ comparados ao grupo controle, porém não houve uma diferença estatisticamente significante entre os grupos lasers. Os autores concluíram que ainda não se pode afirmar que o LBI reduz a movimentação ortodôntica, porém altas e baixas energias de LBI podem apresentar resultados diferentes, sendo que mais estudos nesta área são necessários.

Em 2010 foram publicados dois estudos em ratos avaliando a influência do laser na quantidade de movimentação ortodôntica e ambos constataram que com as doses utilizadas não houve diferenças estatisticamente significantes entre o lado irradiado e o lado não irradiado (GAMA et al., 2010; MARQUEZAN; BOLOGNESE; ARAÚJO, 2010). Marquezan, Bolognese e Araújo (2010), observaram ainda que houve uma inibição da expressão de colágeno imaturo no lado de tração, comparado ao grupo controle.

$\mathrm{Na}$ literatura científica, há pouquíssimos ensaios clínicos que investigaram a influência do laser na movimentação ortodôntica. A maioria destes trabalhos avaliou a influência do laser na retração inicial de caninos (CRUZ et al., 2004; 
LIMPANICHKUL et al., 2006; YOUSSEF et al., 2008; ORLANDO, 2010; SOUSA et al., 2011; DOSHI-MEHTA; BHAD-PATIL, 2012) num período de aproximadamente quatro meses. Apenas um trabalho avaliou a influência do laser na abreviação do tempo de tratamento considerando o tempo total de tratamento (CAMACHO; CUJAR, 2010).

\subsubsection{Efeitos do laser em baixa intensidade na movimentação} ortodôntica em humanos.

Com a intenção de proporcionar ao leitor uma visão panorâmica da laserterapia associada à movimentação ortodôntica, fez-se então uma revisão sistemática da literatura cujo objetivo foi determinar se a laserterapia beneficia a movimentação ortodôntica de forma a acelerar a movimentação e/ou propicia a sua inibição, beneficiando desta forma, a ancoragem e quais as doses e protocolos de LBI já comprovados na literatura.

As bases de dados eletrônicas (Pubmed, periódicos CAPES, BVS - Bireme e Web of Science) foram consultadas retrospectivamente sem delimitação de períodos, usando as seguintes palavras-chave: "laser" combinada com "orthodontic movement" e para as bases de dados em português, as palavras-chave foram: laser e movimentação ortodôntica. A busca se limitou a artigos escritos em inglês, português ou espanhol.

Os critérios de exclusão foram: casos clínicos, opiniões de experts, resumos, utilização de laser de alta intensidade, ausência de descrição da energia em Joules utilizada ou dos parâmetros necessários para o cálculo da mesma, estudos descritivos, revisões de literatura e estudos em células ou animais e uso de laser em baixa intensidade associado às drogas farmacológicas, a pacientes com problemas sistêmicos ou a pacientes com outras terapias associadas.

Os critérios de seleção adotados foram: ensaios clínicos controlados (CCT) e randomizados (RCT) prospectivos; utilização somente de laser em baixa intensidade tanto no comprimento de onda do infravermelho como do vermelho visível; laser com emissão de ondas constantes; todos os parâmetros principais de dosimetria descritos ou pelo menos com condições para a realização do cálculo da energia em Joules; artigos em português, inglês e espanhol e meta-análises. 
O fluxograma abaixo resume o resultado da pesquisa nas bases de dados (Fig. 3).

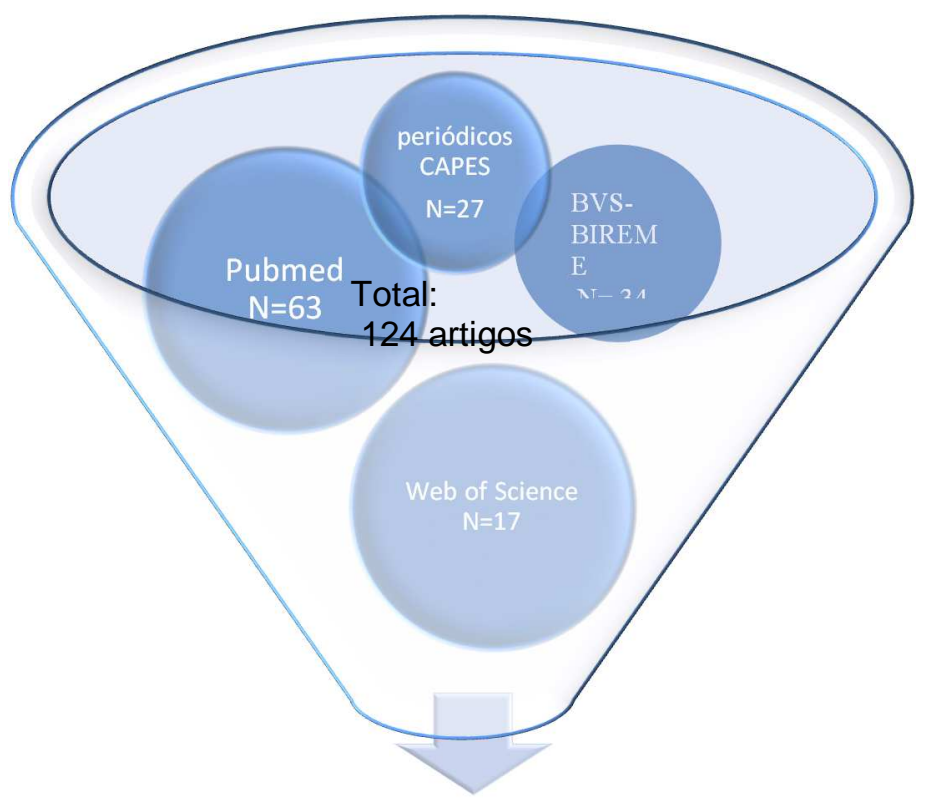

Artigos após a remoção de duplicatas, experimentos relacionando o LBI somente com analgesia e artigos sobre

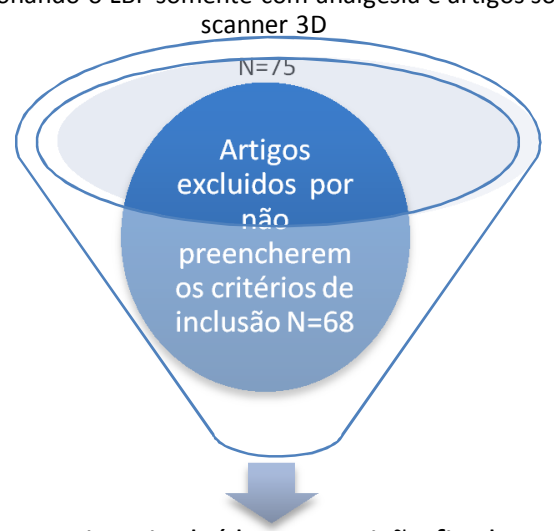

Artigos incluídos na revisão final.

Avaliação completa do texto $\mathrm{N}=7$

Figura 3 - Fluxograma dos resultados das pesquisas nas bases de dados e das diferentes fases de seleção dos artigos que avaliaram a influência do laser em baixa intensidade na movimentação ortodôntica em humanos.

O primeiro trabalho clínico avaliando o LBI na movimentação ortodôntica publicado na literatura foi o de Cruz et al. (2004). Para isto foram selecionados pacientes com necessidade de extração de pré-molares para posterior retração de caninos. Após a extração dos primeiros pré-molares, foi instalado aparelho ortodôntico fixo total e feito o nivelamento e alinhamento até o fio retangular. A partir daí, foi realizada a retração dos caninos por meio de molas de Niti com força de $150 \mathrm{~g}$. O laser de diodo de comprimento de onda de $780 \mathrm{~nm}$ foi aplicado de forma 
pontual e por contato em apenas um dos lados escolhido aleatoriamente com o seguinte protocolo de aplicação: potência de $20 \mathrm{~mW}$, densidade de energia de $\mathbf{5} \mathbf{J} / \mathbf{c m}^{2}, 10$ pontos (5 por vestibular e 5 por lingual) por um período de 10 segundos cada aplicação, resultando numa energia por ponto de $\mathbf{0 , 2}$. Os autores observaram maior velocidade de movimentação nos caninos irradiados, estatisticamente significante, em relação aos dentes placebos, numa proporção de $34 \%$ a mais no período de tempo avaliado (60 dias). As aplicações aconteceram no primeiro dia após ativação do aparelho e nos dias subseqüentes: $3^{\circ}, 7^{\circ}$ e $14^{\circ}$ de cada mês, totalizando $8 \mathbf{J}$ de energia ao mês (4 aplicações mensais). Estas aplicações foram realizadas por 2 meses. Os autores concluíram que a LT apresenta-se como um bom recurso quando se deseja uma diminuição do tempo de tratamento, bem como uma redução de custos.

Posteriormente, Limpanichkul et al. (2006), fizeram a mesma avaliação, porém aumentando a energia depositada nos tecidos. Para isto, foram analisados 12 pacientes durante a retração inicial dos caninos superiores, em que os primeiros prémolares foram extraídos e os caninos foram retraídos para o espaço da extração com molas de $\mathrm{NiTi}$, que liberavam força de $150 \mathrm{~g}$. Após as extrações, os dentes foram nivelados e alinhados até o fio 0,018 de aço e, a partir dessa fase, iniciou-se a retração dos caninos e as aplicações de laser, sendo um lado irradiado e o contralateral, placebo. $O$ estudo foi duplo-cego e os paciente avaliados por 3 meses. O laser de diodo (GaAlAs) de comprimento de onda de $860 \mathrm{~nm}$ foi aplicado em 8 pontos ao redor de um dos caninos escolhidos randomicamente com o seguinte protocolo de aplicação: potência de $100 \mathrm{~mW}$, área do espectro de $0,09 \mathrm{~cm}^{2}$, densidade de potência (DP) $1,11 \mathrm{~W} / \mathrm{cm}^{2}$, tempo de 23 segundos por ponto, densidade de energia $25 \mathrm{~J} / \mathrm{cm}^{2}$, com uma dose de energia de 2,3 $\mathrm{J}$ por ponto, durante três dias consecutivos. $O$ mesmo procedimento foi repetido por mais 3 meses. Para verificação da movimentação dentária, utilizou-se os modelos superiores, tendo como referência, as rugas palatinas, utilizadas para avaliação. Os autores concluíram que não houve diferença estatisticamente significante em relação à velocidade de movimentação ortodôntica entre o lado irradiado e o não irradiado.

Sousa et al. (2008), num ensaio clínico semelhante ao de Cruz et al. (2004), avaliando a influência do laser na velocidade de movimentação ortodôntica, porém utilizando arcos dentários superiores e inferiores na fase inicial de retração de 
caninos com arcos segmentados, os mesmos pontos de aplicação, o mesmo comprimento de onda $(\lambda)$, densidade de energia $\left(780 \mathrm{~nm} / 5 \mathrm{~J} / \mathrm{cm}^{2}\right)$ e energia por ponto $(0,2 \mathrm{~J}$ por ponto e energia total por dente de $2,0 \mathrm{~J})$, porém diminuindo-se para 3 aplicações mensais, dando um total de energia acumulado ao mês de 6J, observaram uma maior velocidade de movimentação estatisticamente significante no grupo de dentes irradiados ( $51 \%$ mais rápido) comparados ao seu contralateral, no período de avaliação de 3 meses, sugerindo um efeito benéfico do laser quando se pretende reduzir o tempo de tratamento.

Youssef et al. (2008), utilizando os mesmos critérios de seleção da amostra que os de Cruz et al. (2004), avaliaram os efeitos do LBI na retração inicial de caninos superiores e inferiores, tendo o contralateral como controle. Foram instaladas molas bilaterais pré-fabricadas com fio Elgiloy, liberando $150 \mathrm{~g} /$ força. $\mathrm{O}$ laser foi irradiado em um dos caninos, nos dias 0, 3, 7 e 14 após a ativação das molas, com o seguinte protocolo de aplicação: comprimento de onda de 809nm; $P=100 \mathrm{~mW}$; $E=8 \mathrm{~J}$ de energia total ao redor da raiz do canino; 40s divididos em 3 pontos: ponto cervical, médio e apical da raiz do canino. Como foram irradiadas as faces vestibular e lingual dos caninos, obteve-se um total de 6 pontos. O ponto cervical e apical foi irradiado por 10 segundos (1) de energia por ponto tanto na face vestibular, quanto na lingual), enquanto que o ponto médio foi irradiado por 20 segundos ( $2 \mathbf{J}$ de energia por ponto, tanto na face vestibular, quanto na lingual). $O$ total de energia ao mês, após 4 aplicações foi de 32J. A distância percorrida pelos caninos foi mensurada com um paquímetro digital em modelos de gesso que foram feitos a cada reativação das molas num intervalo de 21 dias. Os pontos de referência utilizados foram: ponta da cúspide mesial do primeiro molar e ponta da cúspide do canino do mesmo lado. Os resultados demonstraram haver um aumento da velocidade de movimentação ortodôntica do lado irradiado comparado com o lado não irradiado.

Recentemente, dois artigos foram publicados: Genc et al. (2012) em Janeiro/2012 e Doshi-Mehta e Bhad-Patil (2012) em Março/2012.

Genc et al. (2012) avaliaram a retração de incisivos laterais submetidos à laserterapia, tendo um lado como controle. Os parâmetros do laser de diodo $(\lambda=808 \mathrm{~nm})$ utilizado foram: $D E=0,71 \mathrm{~J} / \mathrm{cm} 2$, potência de $20 \mathrm{~mW}$, tempo de 10 segundos por ponto. Os autores observaram um aumento da velocidade de movimentação dentária no grupo laser em relação ao grupo controle. 
Doshi-Mehta e Bhad-Patil (2012) avaliaram também os efeitos da laserterapia na retração inicial de caninos, semelhante aos trabalhos anteriores em relação à mecânica ortodôntica. Após a ativação das molas de retração, o laser foi aplicado em 10 pontos (5 vestibular e 5 lingual), densidade de energia de $5 \mathrm{~J} / \mathrm{cm} 2$, dando um total de $8 \mathrm{~J}$ por aplicação, seguindo-se o mesmo protocolo no terceiro, sétimo e décimo quarto dias. Após este período, o laser foi aplicado a cada 15 dias até a completa retração dos caninos. Os autores concluíram que o aumento médio da taxa de movimentação dos caninos em três meses foi de $54 \%$ na maxila e $58 \%$ na mandíbula, sem causar injúrias ao tecido periodontal.

O único trabalho existente na literatura, que avaliou a influência do LBI na movimentação ortodôntica durante todo o tratamento foi o trabalho de Camacho e Cujar (2010). Eles selecionaram 60 pacientes com má-oclusão semelhante e os dividiram em dois grupos: o grupo laser e o grupo controle. O laser infravermelho $(\lambda=$ $830 \mathrm{~nm}$ ) era aplicado após cada ativação (troca de arcos), mensalmente com o seguinte protocolo: $D E=80 \mathrm{~J} / \mathrm{cm}^{2}, P=100 \mathrm{~mW}, \mathrm{t}=22 \mathrm{~s}$, E por ponto de 2,2 J, 2 pontos por dente (vestibular e lingual) e energia por dente de $\mathbf{4 , 4 J}$, até o final do tratamento. Os autores concluíram que houve uma redução em média de $\mathbf{3 0} \%$ no tempo total de tratamento no grupo laser comparado com o grupo controle.

O quadro 1 resume os principais dados dos trabalhos selecionados na revisão sistemática em ordem decrescente de energia por ponto (J) utilizada e a figura 4 , os pontos de aplicação de LBI relatados na literatura. 
Quadro 1 - Resumo das dosimetrias encontradas na literatura e seus efeitos em humanos para o estímulo da movimentação dentária induzida ortodonticamente.

\begin{tabular}{|c|c|c|c|c|c|c|c|c|c|c|c|}
\hline & autores & $\begin{array}{l}\text { Comprimen } \\
\text { to de onda/ } \\
\text { spot size }\end{array}$ & $\begin{array}{l}\text { Densida } \\
\text { de de } \\
\text { energia } \\
\text { por } \\
\text { ponto }\end{array}$ & potência & $\begin{array}{l}\text { Energia } \\
\text { por } \\
\text { ponto }\end{array}$ & $\begin{array}{l}\text { Número de } \\
\text { pontos por } \\
\text { dente }\end{array}$ & $\begin{array}{l}\text { Total de } \\
\text { energia } \\
\text { por } \\
\text { dia/dente }\end{array}$ & $\begin{array}{l}\text { Tempo } \\
\text { por ponto } \\
\text { (seg) }\end{array}$ & $\begin{array}{l}\text { Total de } \\
\text { energia por } \\
\text { mês }\end{array}$ & Frequência de aplicação & $\begin{array}{l}\text { Aceleração da } \\
\text { movimentação }\end{array}$ \\
\hline 온 & $\begin{array}{l}\text { Limpanichkul } \\
\text { et al. } \\
\text { (2006) }\end{array}$ & $\begin{array}{l}860 \mathrm{~nm} / \\
0,09 \mathrm{~cm}^{2}\end{array}$ & $25 \mathrm{~J} / \mathrm{cm}^{2}$ & $100 \mathrm{~mW}$ & $2,3 \mathrm{~J}$ & $\begin{array}{l}8 \text { pontos: } \\
4 \text { vestibular } \\
4 \text { lingual }\end{array}$ & $18,4 J^{*}$ & $23 \mathrm{~s}$ & $55,2 J^{*}$ & $\begin{array}{l}3 \text { dias consecutivos após } \\
\text { ativação }\end{array}$ & NĀO \\
\hline $\begin{array}{l}70 \\
0 \\
0 \\
0\end{array}$ & $\begin{array}{l}\text { Youssef } \\
\text { et al. } \\
\text { (2008) }\end{array}$ & $\begin{array}{l}809 \mathrm{~nm} \\
?\end{array}$ & $8 \mathrm{~J} / \mathrm{cm}^{2}$ & $100 \mathrm{~mW}$ & $\begin{array}{l}1 \mathrm{~J}(\mathrm{X} \mathrm{2})^{*} \\
2 \mathrm{~J}^{*}\end{array}$ & $\begin{array}{l}6 \text { pontos: } \\
3 \text { vestibular } \\
3 \text { lingual }\end{array}$ & $8 \mathrm{~J}$ & $\begin{array}{l}2 \text { points: } \\
10 \text { s } \\
4 \text { points: } \\
20 \text { s }\end{array}$ & $32 J^{*}$ & $\begin{array}{l}\text { Dias } 0,3,7 \text { e } 14 \\
\text { após cada ativação }\end{array}$ & SIM \\
\hline $\begin{array}{l}\frac{5}{6} \\
\text { E. }\end{array}$ & $\begin{array}{l}\text { Doshi-Mehta e } \\
\text { Bhad- } \\
\text { Patil.(2012) }\end{array}$ & $\begin{array}{l}800 \mathrm{~nm} / \\
0,04 \mathrm{~cm}^{2}\end{array}$ & $5 \mathrm{~J} / \mathrm{cm}^{2}$ & $\begin{array}{l}100 \mathrm{~mW} \\
0,25 \mathrm{~mW} \\
?\end{array}$ & $0,8 J^{*}$ & $\begin{array}{l}10 \\
\text { Pontos: } \\
5 \text { vestibular } \\
5 \text { lingual }\end{array}$ & $8 \mathrm{~J}$ & $\begin{array}{l}40 \mathrm{~s} \\
10 \mathrm{~s} \\
?\end{array}$ & $32 \mathrm{~J}$ & $\begin{array}{l}\text { Dias } 0,3,7 \text { e } 14 \\
\text { após ativação no primeiro } \\
\text { mês e a cada } 15 \text { dias até a } \\
\text { completa retração. }\end{array}$ & SIM \\
\hline $\begin{array}{l}0, \frac{1}{0} \\
\frac{1}{2} \\
\frac{2}{0} \\
\frac{0}{10}\end{array}$ & $\begin{array}{l}\text { Genc et al. } \\
\text { 2012) }\end{array}$ & $\begin{array}{l}808 \mathrm{~nm} \\
0,28 \mathrm{~cm}^{2 *}\end{array}$ & $\begin{array}{l}0,71 \mathrm{~J} / \mathrm{c} \\
\mathrm{m}^{2}\end{array}$ & $20 \mathrm{~mW}$ & $0,2 J^{*}$ & $\begin{array}{l}10 \\
\text { Pontos: } \\
5 \text { vestibular } \\
5 \text { lingual }\end{array}$ & $2 \mathbf{J}^{*}$ & $10 \mathrm{~s}$ & $12 J^{*}$ & $\begin{array}{l}\text { Dias } 0,3,7,14,21 \text { e } 28 \\
\text { após cada ativação }\end{array}$ & SIM \\
\hline $\begin{array}{l}E \\
\frac{E}{19}\end{array}$ & $\begin{array}{l}\text { Cruz et al. } \\
(2004)\end{array}$ & $\begin{array}{l}780 \mathrm{~nm} / \\
0,04 \mathrm{~cm}^{2}\end{array}$ & $5 \mathrm{~J} / \mathrm{cm}^{2}$ & $20 \mathrm{~mW}$ & $0,2 J^{*}$ & $\begin{array}{l}10 \\
\text { Pontos: } \\
5 \text { vestibular } \\
5 \text { lingual }\end{array}$ & $2 J^{*}$ & $10 \mathrm{~s}$ & $8 \mathbf{J}^{*}$ & $\begin{array}{l}\text { Dias } 0,3,7 \text { e } 14 \\
\text { após cada ativação }\end{array}$ & SIM \\
\hline 준 & $\begin{array}{l}\text { Sousa et al. } \\
\text { (2011) }\end{array}$ & $\begin{array}{l}780 \mathrm{~nm} / \\
0,04 \mathrm{~cm}^{2}\end{array}$ & $5 \mathrm{~J} / \mathrm{cm}^{2}$ & $20 \mathrm{~mW}$ & $0,2 \mathrm{~J}$ & $\begin{array}{l}10 \\
\text { Pontos: } \\
5 \text { vestibular } \\
5 \text { lingual }\end{array}$ & $2 \mathrm{~J}$ & $10 \mathrm{~s}$ & $6 \mathrm{~J}$ & $\begin{array}{l}\text { Dias } 0,3 \text { e } 7 \text { após cada } \\
\text { ativação }\end{array}$ & SIM \\
\hline 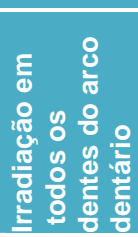 & $\begin{array}{l}\text { Camacho } \\
\text { et al. } \\
\text { (2010) }\end{array}$ & $\begin{array}{l}830 \mathrm{~nm} \\
0,028 \mathrm{~cm}^{2 *}\end{array}$ & $\underset{* *}{80 \mathrm{~J} / \mathrm{cm}^{2}}$ & $100 \mathrm{~mW}^{\star * *}$ & $2,2 J^{* *}$ & $\begin{array}{l}2 \text { pontos: } \\
1 \text { vestibular } \\
1 \text { lingual }\end{array}$ & $\begin{array}{l}\text { 4,4J X } 12 \\
\text { dentes } \\
\text { por arco } \\
\text { (aproxima } \\
\text { damente) }\end{array}$ & $22 s$ & $\begin{array}{l}52,8 \mathbf{J}^{*} \\
\text { por arco } \\
\text { (aproximad } \\
\text { amente) }\end{array}$ & Único dia após ativação & SIM \\
\hline
\end{tabular}

${ }^{* *}$ dados cedidos pelos autores por e-mail cujas correções constam no anexo 1

*dados calculados pela aluna com base nas informações impressas no artigo 



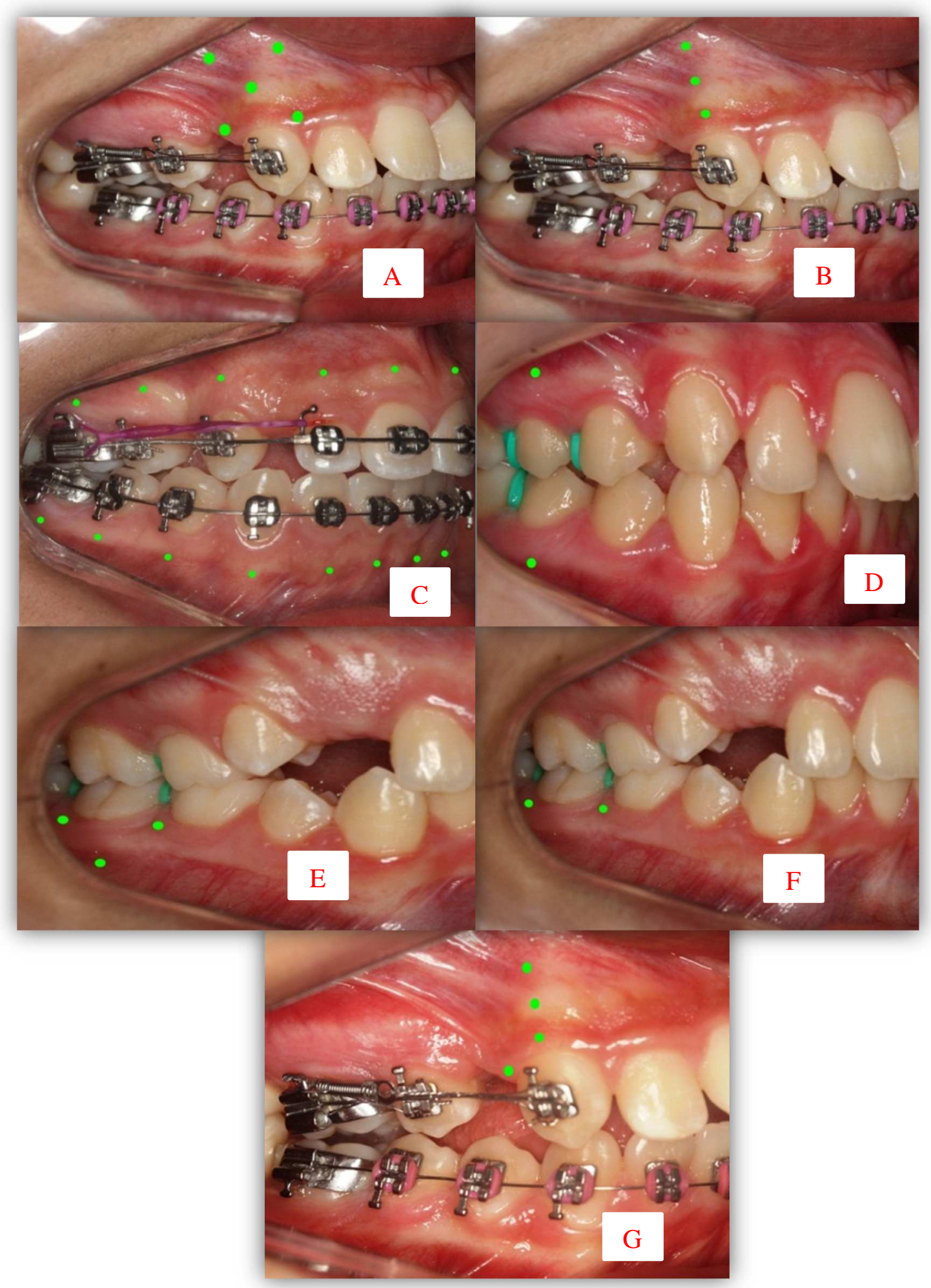

Figura 4- Pontos de aplicação do laser encontrados na literatura. Os mesmos pontos são aplicados no lado lingual, exceto no estudo de Lim, Lew e Tay (1995) em que o laser foi aplicado somente por vestibular. Imagem A: pontos usado por Cruz et al. (2004); Sousa et al. (2011); Angelieri et al. (2011); Tortamano et al. (2009); Genc et al. (2012) e Doshi-Mehta e Bhad-Patil (2012). Imagem B: pontos usados por Youssef et al. (2008). Imagem C: pontos usados por Camacho e Cujar (2010); Turhani et al (2006). Imagem D: pontos utilizados por Lim, Lew e Tay (1995). Imagem E: pontos utilizados por Artés-Ribas, Arnabat-Dominguez e Puigdollers (2012). Imagem F: pontos utilizados por Bicakci et al. (2012); Esper, Nicolau e Arisawa (2011). Imagem G: pontos utilizados por Limpanichkul et al. (2006). 



\subsubsection{Laser em baixa intensidade na supressão da dor}

\section{Mecanismos celulares e bioquímicos de indução da dor}

$\mathrm{Na}$ literatura científica, tem-se observado que $90-95 \%$ dos pacientes ortodônticos relataram dor e que $8-30 \%$ destes pacientes interromperam 0 tratamento por causa dela (BERGIUS; KILIARIDIS; BERGGREN, 2000; POLAT; KARAMAN, 2005; KRISHNAN, 2007).

Normalmente, a movimentação ortodôntica causa algum tipo de sensibilidade dolorosa, principalmente nos primeiros quatro dias pós-ativação. Contudo, os mecanismos da indução da dor resultantes da movimentação ortodôntica não são totalmente esclarecidos (NGAN; KESS; WILSON, 1989; SHIMIZU et al., 1995), porém sabemos que após o estímulo mecânico proveniente da ativação do aparelho ortodôntico, há uma resposta inflamatória aguda caracterizada por vasodilatação no ligamento periodontal, com migração de neutrófilos e macrófagos dos capilares sanguíneos (CONSOLARO, 2002; KRISHNAN; DAVIDOVITCH, 2006). Esta vasodilatação (contração das células endoteliais vasculares) é estimulada pela histamina, oriunda da degranulação dos mastócitos presentes no tecido conjuntivo (MACIEL, 2005). Os mastócitos são verdadeiros guardiões prontos a liberar histamina a qualquer agressão ocorrida nos tecidos.

A histamina é um mediador-chave das respostas locais nas áreas de lesão e também responsável pela dor imediata pós-ativação.

A exsudação plasmática leva para a matriz extracelular uma grande quantidade de macromoléculas ou proteínas livres, dentre elas, a fibrina, a plasmina e as cininas (CONSOLARO, 2012)

As cininas (principalmente a bradicinina) são responsáveis pela dor após 24 horas substituindo a histamina na manutenção da permeabilidade vascular (GRIFFIN; WOOLF, 2008), além de ser um dos mediadores químicos (neurotransmissor excitatório) que estimulam os receptores nociceptivos das terminações nervosas, levando o impulso doloroso até o Sistema Nervoso Central.

A atividade dos receptores nociceptivos é modulada pela ação de substâncias denominadas algiogênicas, como por exemplo, a bradicinina, a serotonina, prostaglandinas, histamina, acetilcolina e outros (MACIEL, 2005).

A serotonina, por exemplo, é um neurotransmissor inibitório (no caso da dor), que quando liberada na terminação pode fechar canais de $\mathrm{K}$, retardando a 
despolarização e assim prolongando o tempo do potencial de ação (GRIFFIN; WOOLF, 2008).

Além dos fatores neurais e plasmáticos envolvidos no estímulo da dor pósativação, ainda temos os fatores celulares.

A chegada dos macrófagos no ligamento periodontal (entre 24 e 72 horas após a aplicação da força) enquanto fagocitam, são responsáveis pela liberação de substâncias para o meio extracelular, como as citocinas, fatores de crescimento e produtos do ácido araquidônico (KRISHNAN; DAVIDOVITCH, 2006; CONSOLARO, 2012).

As citocinas pró-inflamatórias (IL-1, IL2, IL6, IL7 e TNF) estão relacionadas com a fisiopatologia das síndromes dolorosas (GRIFFIN; WOOLF, 2008), enquanto que os produtos do ácido araquidônico, particularmente as prostaglandinas que também são produzidas por outras células do ligamento periodontal derivada do ácido araquidônico pela via metabólica da cicloxigenases (CONSOLARO, 2012), potencializam o efeito da dor nas terminações nervosas livres e são as principais responsáveis pela intensificação da dor após 24h (YAO; FENG; JING, 2003; LEE et al., 2004; REN; VISSINK, 2008), a 48h (GRIEVE et al., 1994) da aplicação da força (dor tardia), como também importantes mediadores da movimentação dentária (YAMASAKI et al., 1984; ARIAS; MARQUEZ-OROZCO, 2006).

A biossíntese de prostaglandinas no ligamento periodontal também é estimulada pela presença de bradicininas (MARKLUND et al., 1994).

As prostaglandinas em si não causam dor, mas potencializam acentuadamente o efeito de outros agentes na produção da dor, como a bradicinina (GRIFFIN; WOOLF, 2008).

A figura 5 representa os principais fatores envolvidos na indução da dor. 


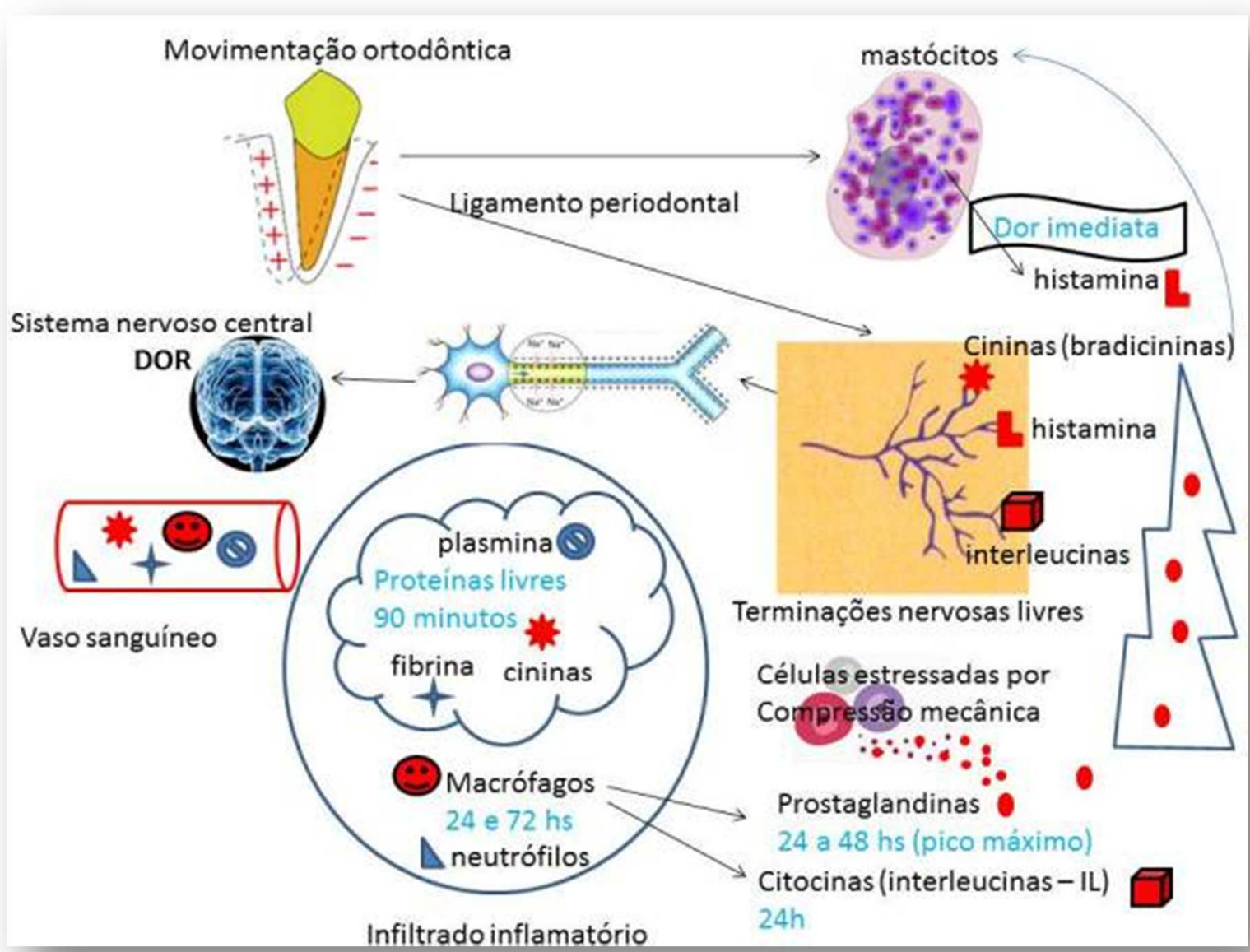

Figura 5 - Representação esquemática dos principais fatores envolvidos na indução da dor relacionado ao movimento ortodôntico. (Fonte: Esquema feito pela aluna MVSS com imagens oriundas de diversos sites).

Para o paciente, os períodos de inflamação aguda são associados a sensações dolorosas e conseqüente redução da função mastigatória. Um reflexo desta fase pode ser observado quando se avalia o fluido gengival dos dentes em movimento, onde elevadas concentrações de mediadores inflamatórios, como citocinas e prostaglandinas, podem ser verificadas (SHIMIZU et al., 1995; KRISHNAN; DAVIDOVITCH, 2006). 


\section{Mecanismos de ação do LBI na inibição da dor}

O uso de drogas farmacológicas (analgésicos e antiinflamatórios) no combate à dor tem sido muito discutido, em virtude das inúmeras desvantagens que oferecem. Além de seus efeitos colaterais e da possibilidade de causar alergias, alguns trabalhos têm comprovado que a movimentação dentária pode ser inibida por meio da administração de antiinflamatórios não-esteroidais, pois estes podem inibir a síntese de prostaglandinas que é um importante mediador da reabsorção óssea (CHUMBLEY; TUNCAY, 1986; LIM; LEW; TAY, 1995; ARIAS; MARQUEZ-OROZCO, 2006), embora Krishnan (2007) tenha concluído que baixas doses de antiinflamatórios prescritas por um ou dois dias nos estágios iniciais após a ativação do aparelho, não afeta a movimentação ortodôntica.

Experimentos que utilizaram estes medicamentos demonstraram significante diminuição no número de osteoclastos, mas nem todos experimentos ocorreram uma diminuição na movimentação dentária, confirmando que as prostaglandinas não são os únicos mediadores da inflamação associada à movimentação dentária induzida (WONG; REYNOLDS; WEST, 1992; RAMOS; FURQUIM; CONSOLARO, 2005; CONSOLARO et al., 2010), contudo, muitos autores tem enfatizado que 0 controle da dor sem o uso de drogas farmacológicas é ideal para o tratamento ortodôntico (BERNHARDT, et al., 2001; POLAT; KARAMAN, 2005; KRISHNAN, 2007).

O uso de anti-inflamatórios esteroidais (glicocorticóides) é descrito na literatura por seus efeitos deletérios no tecido ósseo, diminuindo a proliferação e atividade dos osteoblastos e aumentando a proliferação a atividade dos osteoclastos que ao longo do tempo ocasionará uma perda óssea (TURNER et al., 1995).

As pesquisas têm apontado que uma das possíveis vantagens do uso do LBI é o estímulo da proliferação de osteoblastos, independente do uso de antiinflamatórios esteroidais (FUJIHARA; HIRAKI; MARQUES, 2006)

A grande vantagem do uso do laser para a supressão da dor decorrente da movimentação ortodôntica se dá devido a sua ação não invasiva e não ionizante.

$\mathrm{Na}$ clínica, há praticamente um consenso que a terapia com laser em baixa intensidade causa um efeito analgésico (LIM; LEW; TAY, 1995; TURHANI et al., 2006; YOUSSEF et al., 2008; TORTAMANO et al., 2009; ARTÉS-RIBAS; ARNABATDOMINGUEZ; PUIGDOLLERS, 2012). Desta forma, o laser poderia se tornar um grande auxiliar no tratamento ortodôntico, já que o medo da dor é um dos principais 
fatores que desencorajam muitos pacientes a submeter-se a este tipo de tratamento. (NGAN; KESS; WILSON, 1989; LIM; LEW; TAY, 1995)

O laser terapêutico tem o poder de reduzir a dor por meio de dois mecanismos diferentes: estimulando a produção de betaendorfina (BENEDICENTI, 1982; MONTESINOS, 1988; LAAKSO et al., 1994), um mediador natural produzido pelo organismo para reduzir a dor, e inibindo a liberação do ácido araquidônico (SHIMIZU et al., 1995) a partir das células lesadas, que geraria metabólitos (prostaglandinas) que interagem com os receptores da dor. Enquanto o ácido araquidônico tem efeito local, a betaendorfina tem efeito analgésico em todo o organismo.

Outra forma de ação do laser nos mecanismos de supressão da dor é a repressão da condução dos impulsos nervosos nas terminações dos nervos periféricos, atuando no mecanismo da "bomba de sódio e potássio" e dificultando, portanto, a transmissão do impulso doloroso local. (KASAl et al., 1996). O principal efeito bioelétrico da fotobiomodulação laser é a manutenção do potencial de membrana celular, o que impede que os estímulos dolorosos se propaguem a centros nervosos, isso devido à eficiência da bomba de sódio e potássio ocasionada pela maior disponibilidade de ATP resultante do efeito bioquímico (RICCI, 2003; BENEDICENTI et al., 2008).

Shimizu et al. (1995), verificaram a efetividade do laser em baixa intensidade (diodo laser - GaAlAs) na inibição de prostaglandinas $E_{2}$ (PG-E2) e interleucina 1- $\beta$ (IL-1 $\beta$ ) no ligamento periodontal de dentes movimentados ortodonticamente. Para esta observação, pré-molares extraídos por indicação clínica foram mantidos em meio de cultura após a movimentação ortodôntica. As células do ligamento periodontal, anteriormente estimuladas pela força ortodôntica, foram irradiadas com o laser, e observou-se inibição significante na produção de PG $\mathbf{E}_{\mathbf{2}}$ e IL-1 $\boldsymbol{\beta}$. Este resultado sugere a possibilidade do laser apresentar grande efeito terapêutico no controle da dor durante a movimentação ortodôntica.

A inibição das prostaglandinas induzidas pela LT em células comprimidas do ligamento periodontal se dá provavelmente pela inibição da enzima ciclooxigenase COX2 responsável pela formação das prostaglandinas (KOTOE et al., 2010)

O efeito analgésico do laser em baixa intensidade foi comprovado por Benedicenti (1982) num estudo em humanos, por meio do método radioimunológico. 
Observou que, após a aplicação do laser, houve um aumento de beta-endorfina no líquido cefalorraquidiano, que é responsável pelo efeito analgésico. Também Laakso et al. (1994), num ensaio clínico controlado, demonstraram um aumento de $\mathbf{A C T H}^{*} \mathbf{e}$ $\boldsymbol{\beta}$ - endorfinas mensuradas por meio de amostras de plasmas periféricos obtidas de pacientes com dor crônica miofacial após a aplicação de laser nos pontos gatilhos. Além disso, Montesinos et al. (1988) relataram um aumento na síntese de encefalinas $^{* *}$ e endorfinas em animais de laboratório, após uma única sessão de LBI no lobo anterior da glândula pituitária.

Ataka (1989) verificou a inibição de transmissores nociceptivos como a bradicinina, após a irradiação com laser em baixa intensidade. Os nociceptores são os receptores presentes nas terminações nervosas livres do axônio do neurônio aferente primário (fibras mielínicas finas A-delta e amielínicas $C$ ), capazes de detectar estímulos dolorosos. A informação gerada nos nociceptores é conduzida até o gânglio da raiz dorsal, e a partir deste, até a medula espinal (GRIFFIN; WOOLF, 2008).

Kasai et al. (1996) estudaram os efeitos da irradiação com laser em baixa intensidade sobre as respostas eletricamente provocadas no nervo cutâneo dorsal lateral de coelhos anestesiados. Foi evidenciado que a aplicação do laser reprime a condução dos impulsos nervosos das fibras $A$ delta aferentes não mielinizadas nos nervos sensoriais periféricos, que causam a sensação dolorosa. Com isto, concluiuse que o laser em baixa intensidade age como um supressor reversível direto da atividade neuronal.

O LBI estimula a degranulação dos mastócitos (VASHEGHANI et al., 2008; PEREIRA et al., 2010; MONTEIRO et al., 2011), aumentando a liberação de histamina, desta forma, a vasodilatação é promovida por período maior de tempo. Por conseguinte, a permeabilidade é aumentada, facilitando o aporte sanguíneo com células de defesa e nutrientes para a região afetada. Com a diminuição de mediadores químicos, promovida pela laserterapia, tais como prostaglandinas (SHIMIZU et al., 1995) e leucotrienos, ocorre aumento no limiar da dor e

\footnotetext{
"ACTH ou hormônio adrenocorticotrófico é um polipeptídeo produzido na adeno-hipófise que atua sobre as células da camada cortical da glândula adrenal, estimulando-as a sintetizar e liberar seus hormônios, principalmente o cortisol que está diretamente envolvido na resposta ao estresse. Sua forma sintética, chamada de hidrocortisona é um anti-inflamatório.

Encefalinas são neurotransmissores narcóticos secretados pelo encéfalo que semelhantes à morfina, elas se ligam a sítios estereoespecíficos de receptores opióides no cérebro (reagindo com os mesmos receptores neurais do cérebro que a heroína), aliviando a dor (mecanismo de analgesia) e produzindo uma sensação de euforia.
} 
diminuição do edema. Este mecanismo é o mesmo proporcionado por antiinflamatórios não esteroidais (ARIAS; MARQUEZ-OROZCO, 2006), porém, com a vantagem de não causar efeitos colaterais, portanto a diminuição da dor ocorre em parte pela redução do edema e inibição das prostaglandinas. Além disso, a permeabilidade da membrana citoplasmática aumenta em relação aos íons Ca++, $\mathrm{Na}+$ e $\mathrm{K}+$ e em consequência disto, a síntese de endorfina aumenta enquanto que a quantidade de bradicinina e atividades das fibras $\mathbf{C}$ de condução de estímulos dolorosos diminuem (WAKABAYASHI et al., 1993), ou seja, a aplicação de LBI mantém a membrana celular em repouso por mais tempo, o que por sua vez diminui a sensibilidade à dor.

Poucos estudos clínicos na Ortodontia têm demonstrado a eficiência do laser para suprimir a dor. A maioria destes estudos avaliou os efeitos do laser em apenas um dente comparado com o seu lado oposto (placebo): ou molares em sua separação com elastômeros, ou caninos em fase de retração inicial (LIM; LEW; TAY, 1995; YOUSSEF et al., 2008; ANGELIERI et al., 2011; ESPER; NICOLAU; ARISAWA, 2011; ARTÉS-RIBAS; ARNABAT-DOMINGUEZ; PUIGDOLLERS, 2012; BICAKCl, et al., 2012). Outros estudos avaliaram os efeitos do laser na supressão da dor em todos os dentes da arcada dentária, após a colocação do primeiro arco (grupo experimental), em comparação com o grupo controle (TURHANI et al., 2006; TORTAMANO et al., 2009).

Para selecionar o máximo de trabalhos clínicos que pesquisaram a influência do laser na analgesia após a movimentação dentária, fez-se uma busca sistemática de artigos na literatura. As bases de dados pesquisadas foram: Pubmed, Periódicos CAPES, LILACS e Web of Science sem delimitação de períodos.

As palavras chave utilizadas para a busca em bases internacionais foram: pain, laser e orthodontic movement e para as bases nacionais, as palavras chave foram: dor, laser e movimentação ortodôntica.

Os critérios de seleção adotados foram: ensaios clínicos controlados (CCT) e randomizados (RCT) prospectivos; cegos e duplo cegos, utilização somente de laser em baixa intensidade tanto no comprimento de onda do infravermelho como do vermelho visível; laser com emissão de ondas constantes; todos os parâmetros principais de dosimetria descritos; uso de escala visual analógica como recurso para aferição da dor; artigos em português, inglês e espanhol e meta-análises. 
Os critérios de exclusão foram: casos clínicos, opiniões de experts, resumos, utilização de laser de alta intensidade, ausência de descrição dos parâmetros necessários para o cálculo da energia em Joules, estudos descritivos e revisões de literatura.

O fluxograma abaixo resume o resultado da pesquisa nas bases de dados (Fig.6).

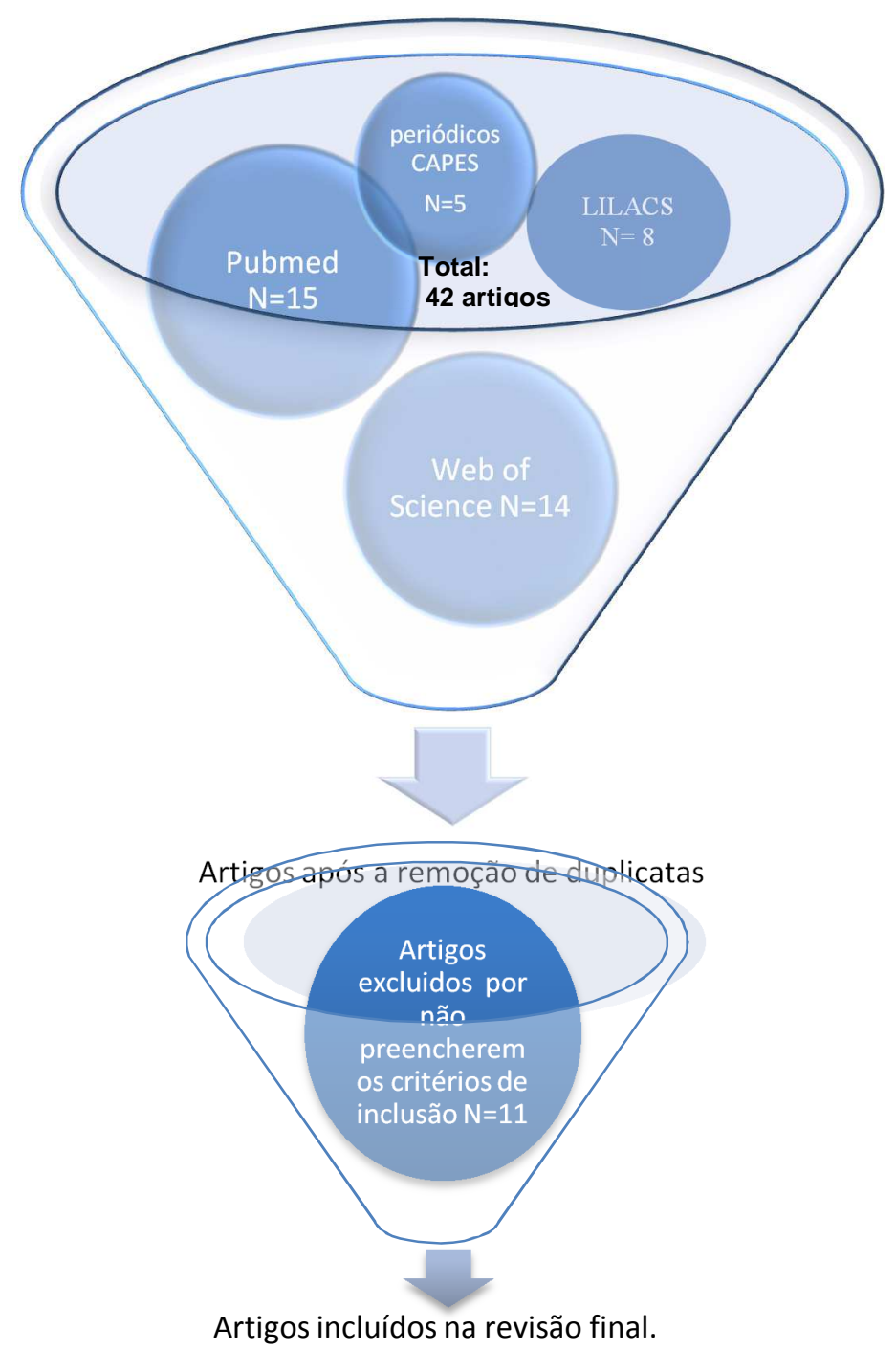

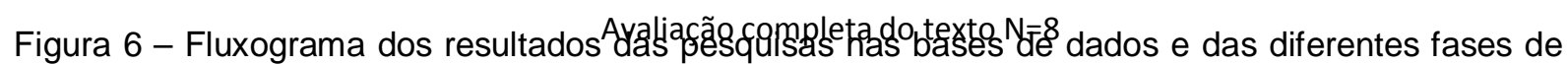
seleção dos artigos que avaliaram a influência do laser em baixa intensidade na analgesia pósmovimentação ortodôntica. 
A seguir encontra-se o resumo dos oito artigos selecionados e o quadro 2, os principais dados destes trabalhos para efeitos comparativos. Os trabalhos abaixo descritos aparecem classificados por ordem crescente de energia (J) por ponto utilizada por cada autor para uma melhor compreensão sobre o efeito sobre a analgesia.

Angelieri et al. ( 2011) num ensaio clínico cego, avaliaram a influência do laser de diodo infravermelho na redução da dor no período pós-ativação da retração dos caninos com molas fechadas de NiTi. Um canino de cada paciente foi selecionado aleatoriamente para ser irradiado com laser, imediatamente após as ativações e depois de 3 e 7 dias. Os caninos homólogos foram utilizados como grupo controle e foi realizada somente a simulação de aplicação do laser. O laser irradiado foi o de diodo (ArGaAl), a um comprimento de onda de 780nm e uma potência de $20 \mathrm{~mW}$, densidade de energia na superfície do tecido alvo de $5 \mathrm{~J} / \mathrm{cm} 2$, durante 10 s por ponto, resultando numa energia de $\mathbf{0 , 2} \mathbf{J}$ por ponto e energia total (Et) de 2J. Para avaliação do efeito analgésico, foi utilizada a escala visual analógica (VAS), na qual os pacientes marcavam de 0 a 10, em consonância com a dor experimentada nos tempos de 12, 24, 48 e 72 horas pós-ativação das molas e aplicação do laser. Todo o procedimento foi novamente realizado um mês depois, no momento da reativação da retração dos caninos e novos dados em relação à dor experimentada foram coletados, utilizando-se dos mesmos recursos. Os autores verificaram não haver diferenças entre o lado irradiado e o lado não irradiado, concluindo que o laser em baixa intensidade no protocolo de aplicação utilizado não foi eficiente em termos estatísticos para o controle da dor pós-ativação.

Bicakci et al. (2012) estudaram o efeito do LBI na inibição da dor após a colocação das bandas nos primeiros molares por meio de uma escala visual analógica decorridos $5 \mathrm{~min}$, $1 \mathrm{~h}$ e $24 \mathrm{hs}$ pós-ativação e também avaliaram a presença de prostaglandinas $\left(\mathrm{PGE}_{2}\right)$ no fluido gengival crevicular comparando-se os molares irradiados com os não irradiados. O fluido gengival foi coletado antes e após 1 hora da aplicação de laser por meio de tiras de papel inseridas $1 \mathrm{~mm}$ no sulco gengival por 30 segundos. Decorridos 24 horas da primeira aplicação de laser, nova aplicação foi realizada e novo fluido gengival foi coletado. O protocolo de aplicação do laser $(\lambda=820 \mathrm{~nm})$ foi: $D E=7,96 \mathrm{~J} / \mathrm{cm}^{2}, P=50 \mathrm{~mW}, 5$ segundos por ponto, energia por ponto de $\mathbf{0 , 2 5} \mathbf{J}, 4$ pontos irradiados (gengiva mesiovestibular, mesiolingual, distovestibular e distolingual). Os autores verificaram não haver diferenças 
estatisticamente significantes na avaliação da dor após 5 minutos e 1 hora da ativação, porém houve diferenças estatisticamente significantes após 24 horas da aplicação do laser. As diferenças nos níveis de prostaglandinas entre os grupos foram encontradas somente $1 \mathrm{~h}$ e $\mathbf{2 4 h}$ após a aplicação de laser, concluindo que o laser pode ser um excelente recurso para redução da dor pós-ativação ortodôntica.

Esper, Nicolau e Arisawa (2011) avaliaram a efetividade da luz coerente (LBI) comparada com a luz não coerente (LED) na inibição da dor em 55 pacientes após a inserção de separadores elásticos. Estes pacientes foram divididos em 4 grupos: controle (nenhuma terapia), placebo (simulação de aplicação de luz), protocolo laser e protocolo LED. O experimento foi iniciado pelos grupos controle e placebo e após a inserção dos elastômeros e simulação da aplicação da luz no grupo placebo, estes pacientes receberam uma escala visual analógica (0 a 10) para marcação da dor experimentada após 2, 24, 48, 72, 96 e 120 horas. Após este tempo, os separadores elásticos foram removidos e decorridos o mínimo de 7 e o máximo de 30 dias, os pacientes do grupo placebo foram distribuídos entre os dois grupos experimentais: Laser e LED. Novos elastômeros foram inseridos na mesial e distal dos molares e os dados foram coletados por meio de uma escala visual analógica, como descrito anteriormente. O laser utilizado foi o de diodo na faixa de comprimento de onda do vermelho visível (660nm), cujo protocolo de aplicação foi: $D E=4 J / \mathrm{cm}^{2}, P=0,03 \mathrm{~W}$, tempo=25s, $\mathbf{0 , 7} \mathbf{J}$ de energia por ponto, aplicado em dois pontos na gengiva (mesial e distal) por vestibular e os mesmos pontos por lingual, enquanto que o LED utilizado foi na faixa de comprimento de onda de $640 \mathrm{~nm}, \mathrm{DE}=4 \mathrm{~J} / \mathrm{cm}^{2}, 0,10 \mathrm{~W}$ de potência por 70segundos. Os autores concluíram que nos protocolos utilizados neste estudo, o grupo LED teve uma significante redução da dor (em torno de 56\%) entre 2 e 120hs comparado com o grupo controle, enquanto que o grupo laser não teve uma redução da dor estatisticamente significante.

Lim, Lew e Tay (1995), num estudo duplo cego, instalaram separadores elásticos para indução da dor nos contatos interproximais de pré-molares superiores e inferiores de 39 indivíduos. O laser de diodo (AIGaAs), com comprimento de onda de $830 \mathrm{~nm}$, potência de $30 \mathrm{~mW}$ foi aplicado diretamente no terço médio da raiz, de forma pontual e por contato. Os indivíduos foram divididos em três subgrupos de acordo com os diferentes tempos de aplicação do laser (15, 30 e 60 segundos), que receberam $\mathbf{0 , 4 5} \mathbf{J}, \mathbf{0 , 9 5} \mathrm{J}$ e $\mathbf{1 , 8} \mathrm{J}$ de energia por ponto respectivamente. $\mathrm{O}$ grupo 
controle (contralateral) recebeu aplicação de luz placebo por 30 segundos. O objetivo deste estudo foi avaliar o efeito imediato no alívio da dor com a aplicação de laser e também no decorrer do tempo.

Uma escala foi utilizada para quantificar a dor experimentada em cada quadrante (Visual Analogue Scale - VAS) na qual foi anotado um score (0 a 10) antes da colocação dos separadores, após 5 minutos da colocação dos separadores e imediatamente após a aplicação de laser (avaliado no primeiro dia). Nos quatro dias seguintes foi anotado um score antes e após a aplicação de laser. Os autores concluíram que não há efeito terapêutico imediato com a aplicação de laser e que apesar de não haver diferença estatisticamente significante nos resultados devido à subjetividade da avaliação da sintomatologia dolorosa, os grupos tratados com laser com energia recebida pelo tecido alvo de $0,95 \mathrm{~J}$ e $1,8 \mathrm{~J}$ demonstraram uma média de níveis de dor mais baixas no segundo e terceiro dia, quando comparados ao grupo placebo, sugerindo que o laser em baixa intensidade apresenta capacidade de reduzir a intensidade de dor provocada pela movimentação ortodôntica.

Youssef et al. (2008), num estudo em humanos, também avaliaram a inibição da sensibilidade dolorosa estimulada pela movimentação ortodôntica. O laser foi irradiado em um dos caninos, nos dias 0, 3, 7 e 14 após a ativação das molas, com o seguinte protocolo de aplicação: comprimento de onda de $809 \mathrm{~nm} ; P=100 \mathrm{~mW} ; E=$ $8 \mathrm{~J}$ de energia total ao redor da raiz do canino; 40s divididos em 3 pontos: ponto cervical, médio e apical da raiz do canino. Como foram irradiadas as faces vestibular e lingual dos caninos, obteve-se um total de 6 pontos. O ponto cervical e apical foi irradiado por 10 segundos (1 $\mathbf{J}$ de energia por ponto) tanto na face vestibular, quanto na lingual, enquanto que o ponto médio foi irradiado por 20 segundos (2J de energia por ponto), tanto na face vestibular, quanto na lingual. Para avaliação da dor, foi utilizada uma escala visual analógica que era preenchida quando o paciente voltava para nova ativação das molas (após um mês) relembrando a dor experimentada no período. Os resultados demonstraram haver uma redução da dor estatisticamente significante no grupo de dentes irradiados comparados com o grupo não irradiado.

Artés-Ribas, Arnabat-Dominguez e Puigdollers (2012) avaliaram a analgesia promovida pela irradiação laser após colocação de separadores elásticos em molares e pré-molares, por meio de uma escala visual analógica preenchida após 5 minutos, 6h, 24h, 48h e $72 \mathrm{hs}$ da colocação dos separadores. Participaram deste 
estudo 20 pacientes e um quadrante de cada paciente escolhido aleatoriamente foi irradiado e o outro serviu como controle. O protocolo de utilização do laser utilizado foi: comprimento de onda de $830 \mathrm{~nm}$, potência de $100 \mathrm{~mW}$, densidade de energia de $5 \mathrm{~J} / \mathrm{cm}^{2}$, pelo tempo de 20 segundos por ponto, $2 \mathbf{J}$ de energia por ponto, sendo que seis pontos foram irradiados (dois pontos na gengiva marginal mesial e distal e um ponto no terço médio da raiz tanto por vestibular como por lingual), totalizando $\mathbf{1 2 J}$ por dente. Os autores verificaram que o grupo de dentes irradiados apresentaram menores níveis de dor a partir de $6 \mathrm{~h}$ da irradiação comparados com o seu contralateral.

Tortamano et al (2009) avaliaram a influência do laser na analgesia em 60 pacientes após a inserção do primeiro arco ortodôntico, num ensaio clínico duplocego. Os pacientes foram divididos em 6 subgrupos (10 pacientes cada): grupo experimental maxila (somente a maxila recebeu irradiação), grupo experimental mandíbula (somente mandíbula recebeu irradiação), grupo placebo maxila (simulação da aplicação de laser na maxila), grupo placebo mandíbula (simulação da aplicação de laser na mandíbula), grupo controle maxila (aparelho ortodôntico na maxila, sem aplicação de laser) e grupo controle mandíbula (aparelho ortodôntico mandíbula, sem aplicação de laser). O laser utilizado foi o laser de diodo, com comprimento de onda de $830 \mathrm{~nm}$, potência de $30 \mathrm{~mW}, 16$ segundos por ponto, num total de 10 pontos (5 vestibular e 5 lingual), resultando numa energia de $\mathbf{0 , 5} \mathbf{J}$ por ponto e $5 \mathbf{J}$ por dente. Foi realizada a aplicação em apenas um único dia após a ativação e o paciente foi orientado a marcar num escala visual analógica com a pontuação de 0 a 10 durante 7 dias consecutivos de acordo com a dor experimentada. Os autores concluíram que a aplicação de laser dentro dos parâmetros adotados, conseguiu controlar a dor após a inserção de primeiro arco, havendo diferenças estatisticamente significantes entre o grupo experimental e os outros dois grupos (placebo e controle) e também observaram não haver diferenças estatisticamente significantes em relação à inibição da dor quando comparadas a maxila e a mandíbula.

Turhani et al. (2006), avaliaram o efeito do laser de diodo (comprimento de onda de $670 \mathrm{~nm}$; potência de $75 \mathrm{~mW}$; tempo de duração de 30 segundos por dente, 2,25J de energia por dente) em 38 pacientes submetidos ao tratamento ortodôntico com aparelho fixo. O laser foi aplicado no centro de resistência de 542 dentes (terço médio) imediatamente e também após 6, 30 e 54 horas pós-inserção dos arcos 
ortodônticos. Um grupo controle (38 pacientes) recebeu apenas irradiação de luz placebo. Os resultados revelaram menores níveis de dor no grupo irradiado com laser até $\mathbf{3 0}$ horas após a ativação ortodôntica. Depois de 54 horas da irradiação, não houve diferença estatisticamente significante entre os dois grupos. Os autores concluíram que a laserterapia pode ter efeitos positivos na supressão da dor durante o tratamento ortodôntico. 
Quadro 2: Dosimetrias utilizadas pelos autores na intenção de analgesia pós-ativação ortodôntica

\begin{tabular}{|c|c|c|c|c|c|c|c|c|c|c|}
\hline$\frac{0}{\frac{2}{2}}$ & autores & $\begin{array}{l}\text { Comprimento } \\
\text { de onda/spot } \\
\text { size }\end{array}$ & $\begin{array}{l}\text { Densidade de } \\
\text { energia por } \\
\text { ponto }\end{array}$ & Potência & $\begin{array}{l}\text { Energia por } \\
\text { ponto }\end{array}$ & $\begin{array}{l}\text { Número de } \\
\text { pontos }\end{array}$ & $\begin{array}{l}\text { Energia } \\
\text { total (por } \\
\text { dente) }\end{array}$ & $\begin{array}{l}\text { Tempo por } \\
\text { ponto } \\
\text { (segundos) }\end{array}$ & $\begin{array}{l}\text { Frequência de } \\
\text { aplicação }\end{array}$ & $\begin{array}{l}\text { Inibição } \\
\text { da dor }\end{array}$ \\
\hline $\begin{array}{l}\frac{c}{1} \\
\frac{1}{0} \\
0\end{array}$ & $\begin{array}{l}\text { Angelieri } \\
\text { et al } \\
\text { (2011) }\end{array}$ & $\begin{array}{l}780 \mathrm{~nm} \\
{ }^{*} \mathrm{~A}=0,04 \mathrm{~cm}^{2}\end{array}$ & $5 \mathrm{~J} / \mathrm{cm}^{2}$ & $20 \mathrm{~mW}$ & $0,2 \mathrm{~J}$ & $\begin{array}{l}10 \text { pontos: } \\
5 \text { vestibular } \\
5 \text { lingual }\end{array}$ & $2 \mathrm{~J}$ & $10 \mathrm{~s}$ & $\begin{array}{l}\text { Dias } 0,3 \text { e } 7 \text { após a } \\
\text { ativação }\end{array}$ & NĀO \\
\hline $\begin{array}{l}\frac{0}{\sigma} \\
0 \\
0 \\
0 \\
\stackrel{0}{E}\end{array}$ & $\begin{array}{l}\text { Bicakci et } \\
\text { al. } \\
(2012)\end{array}$ & $\begin{array}{l}820 \mathrm{~nm} \\
\mathrm{~A}=0,0314 \mathrm{~cm}^{2}\end{array}$ & $7,96 \mathrm{~J} / \mathrm{cm}^{2}$ & $50 \mathrm{~mW}$ & $0,25 \mathrm{~J}$ & $\begin{array}{l}4 \quad \text { pontos:2 } \\
\text { vestibular e } 2 \\
\text { lingual }\end{array}$ & $1 \mathrm{~J}$ & $30 \mathrm{~s}$ & $\begin{array}{l}\text { Imediatamento após } \\
\text { a ativação e } 24 \text { horas } \\
\text { após a ativação }\end{array}$ & $\begin{array}{l}\text { NÃO } \\
\text { (Imediatamente } \\
\text { após) } \\
\text { SIM } \\
\text { (24 hs após) }\end{array}$ \\
\hline $\begin{array}{l}\frac{1}{0} \\
\varepsilon\end{array}$ & $\begin{array}{l}\text { Lim et al. } \\
\text { (1995) }\end{array}$ & $\begin{array}{l}830 \mathrm{~nm} \\
{ }^{*} \mathrm{~A}=0,50 \mathrm{~cm}^{2}\end{array}$ & $0,9 \mathrm{~J} / \mathrm{cm}^{2}$ & $30 \mathrm{~mW}$ & $0,45 J$ & 1 ponto & $0,45 J$ & $15 s$ & $\begin{array}{l}5 \text { dias consecutivos } \\
\text { após a ativação }\end{array}$ & NÃO \\
\hline 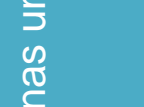 & $\begin{array}{l}\text { Esper et al. } \\
\text { (2011) }\end{array}$ & $\begin{array}{l}660 \mathrm{~nm} \\
A=0,19 \mathrm{~cm}^{2}\end{array}$ & $4 \mathrm{~J} / \mathrm{cm}^{2}$ & $30 \mathrm{~mW}$ & $0,7 \mathrm{~J}$ & $\begin{array}{l}4 \text { pontos: } \\
2 \text { vestibular } \\
2 \text { lingual }\end{array}$ & ${ }^{\star} 2,8 \mathrm{~J}$ & $25 \mathrm{~s}$ & $\begin{array}{l}\text { Único dia após a } \\
\text { ativação }\end{array}$ & NÃO \\
\hline$\frac{\frac{1}{\Phi}}{\frac{0}{c \mid}}$ & $\begin{array}{l}\text { Lim et al. } \\
\text { (1996) }\end{array}$ & $\begin{array}{l}830 \mathrm{~nm} \\
{ }^{*} \mathrm{~A}=0,50 \mathrm{~cm}^{2}\end{array}$ & $0,9 \mathrm{~J} / \mathrm{cm}^{2}$ & $30 \mathrm{~mW}$ & $0,95 \mathrm{~J}$ & 1 ponto & $0,95 \mathrm{~J}$ & $30 \mathrm{~s}$ & $\begin{array}{l}5 \text { dias consecutivos } \\
\text { após a ativação }\end{array}$ & $\begin{array}{l}\text { SIIM } \\
(n s)\end{array}$ \\
\hline$\frac{E}{1}$ & $\begin{array}{l}\text { Lim et al. } \\
\text { (1996) }\end{array}$ & $\begin{array}{l}830 \mathrm{~nm} \\
{ }^{*} \mathrm{~A}=0,50 \mathrm{~cm}^{2}\end{array}$ & $0,9 \mathrm{~J} / \mathrm{cm}^{2}$ & $30 \mathrm{~mW}$ & $1,8 \mathrm{~J}$ & 1 ponto & $1,8 \mathrm{~J}$ & $60 \mathrm{~s}$ & $\begin{array}{l}5 \text { dias consecutivos } \\
\text { após a ativação }\end{array}$ & $\begin{array}{l}\text { SIM } \\
\text { (ns) }\end{array}$ \\
\hline 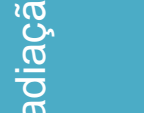 & $\begin{array}{l}\text { Youssef et } \\
\text { al. } \\
(2008)\end{array}$ & $\begin{array}{l}809 \mathrm{~nm} \\
\mathrm{~A}=?\end{array}$ & $8 \mathrm{~J} / \mathrm{cm}^{2}$ & $100 \mathrm{~mW}$ & $\begin{array}{l}{ }^{*} 1 \mathrm{~J}(\mathrm{X} 2) \\
{ }^{*} 2 \mathrm{~J}\end{array}$ & $\begin{array}{l}6 \text { pontos: } \\
3 \text { vestibular } \\
3 \text { lingual }\end{array}$ & $8 \mathrm{~J}$ & $\begin{array}{l}2 \text { pontos: } 10 \mathrm{~s} \\
1 \text { ponto: } 20 \mathrm{~s}\end{array}$ & $\begin{array}{l}\text { Dias } 0,3,7 \text { e } 14 \text { após } \\
\text { ativação }\end{array}$ & SIM \\
\hline 는 & $\begin{array}{l}\text { Artés- } \\
\text { Ribas et al. } \\
\text { (2012) } \\
\end{array}$ & $\begin{array}{l}830 \mathrm{~nm} \\
A=0,4 \mathrm{~cm}^{2}\end{array}$ & $5 \mathrm{~J} / \mathrm{cm}^{2}$ & $100 \mathrm{~mW}$ & $2 \mathrm{~J}$ & $\begin{array}{l}6 \text { pontos: } \\
3 \text { vestibular } \\
3 \text { lingual }\end{array}$ & $12 J$ & $20 \mathrm{~s}$ & $\begin{array}{l}\text { Imediatamente após } \\
\text { a ativação }\end{array}$ & SIM \\
\hline $\begin{array}{l}\text { 요 } \\
\text { 응 } \\
\text { 인 }\end{array}$ & autores & $\begin{array}{l}\text { Comprimento } \\
\text { de onda/spot } \\
\text { size }\end{array}$ & $\begin{array}{l}\text { Densidade de } \\
\text { energia por } \\
\text { ponto }\end{array}$ & Potência & $\begin{array}{l}\text { Energia por } \\
\text { ponto }\end{array}$ & $\begin{array}{l}\text { Número de } \\
\text { pontos }\end{array}$ & $\begin{array}{l}\text { Energia } \\
\text { total (por } \\
\text { dente) }\end{array}$ & $\begin{array}{l}\text { Tempo por } \\
\text { ponto } \\
\text { (segundos) }\end{array}$ & $\begin{array}{l}\text { Frequência de } \\
\text { aplicação }\end{array}$ & Inibição da dor \\
\hline$\frac{\varepsilon}{1}$ & $\begin{array}{l}\text { Tortamano } \\
\text { et al. } \\
(2009)\end{array}$ & $\begin{array}{l}830 \mathrm{~nm} \\
A=0,03 \mathrm{~cm}^{2}\end{array}$ & $16 \mathrm{~J} / \mathrm{cm}^{2}$ & $30 \mathrm{~mW}$ & $0,5 \mathrm{~J}$ & $\begin{array}{l}10 \text { pontos: } \\
5 \text { vestibular } \\
5 \text { lingual }\end{array}$ & $5 \mathrm{~J}$ & $16 s$ & $\begin{array}{l}\text { Único dia após a } \\
\text { ativação }\end{array}$ & SIM \\
\hline 过 & $\begin{array}{l}\text { Turhani et } \\
\text { al. } \\
(2006)\end{array}$ & $\begin{array}{l}670 \mathrm{~nm} \\
{ }^{\star} \mathrm{A}=0,53 \mathrm{~cm}^{2}\end{array}$ & $4,25 \mathrm{~J} / \mathrm{cm}^{2}$ & $75 \mathrm{~mW}$ & *2,25J & $\begin{array}{l}1 \text { ponto: } \\
\text { centro de } \\
\text { resistência }\end{array}$ & *2,25J & $30 \mathrm{~s}$ & $\begin{array}{l}\text { Único dia após a } \\
\text { ativação }\end{array}$ & SIM \\
\hline
\end{tabular}

"dados calculados pela aluna com base nas informações impressas no artigo

ns- valores médios maiores para inibição da dor, porém sem diferenças estatisticamente significantes (tendência de inibição da dor) 
A capacidade da fototerapia em promover o alívio da dor é dose-dependente (LAAKSO; CABOT, 2005).

Os pontos de aplicação do laser são variáveis e a literatura apresenta várias opções como demonstrado na figura 4.

\subsection{Ancoragem Ortodôntica}

O termo ancoragem, na sua aplicação ortodôntica, pode ser definido como a habilidade de resistir ao movimento dentário indesejado (FELDMAN; BONDEMARK, 2006) que pode ocorrer por motivo fisiológico ou pela força à mecânica ortodôntica. Tem sido considerada por muitos ortodontistas um dos fatores limitantes no tratamento ortodôntico e o seu controle é decisivo para uma correta finalização (THIRUVENKATACHARI et al., 2006; BENSON et al., 2007; ARAÚJO et al., 2012), principalmente quando se necessita de máxima ancoragem (MARTINS; BUSCHANG; GANDINI JR, 2009).

Segundo Petrelli (1993), um dos problemas que aflige o profissional no planejamento e tratamento ortodôntico diz respeito à ancoragem dos segmentos dentários posteriores. Estes absorvem, praticamente, as consequências das diversas forças aplicadas durante a movimentação dentária, tendendo a perder suas posições em direção mesial, o que acarretará perda de espaço, tornando-se prioritário um reforço de ancoragem nestes dentes.

Nos tratamentos que são indicadas exodontias como base para as correções ortodônticas, deve-se atentar para uma série de variáveis, sendo o controle da ancoragem um fator essencial para o sucesso do plano de tratamento elaborado (ARAÚJO et al., 2012). Na retração dos caninos superiores, os dentes posteriores constituem a unidade de ancoragem, ou seja, um apoio no qual a força é aplicada, sendo seu movimento mesial indesejado, às vezes de forma parcial (ancoragem mínima ou média) ou total (ancoragem máxima).

A máxima ancoragem foi definido por Nanda (1997) como a perda de menos que $\mathbf{2 5 \%}$ de fechamento do espaço da extração por meio da perda de ancoragem posterior. Quando a ancoragem máxima é solicitada, a perda de ancoragem é maior em paciente classe I de Angle $(\mathbf{0 , 6} \mathbf{m m})$ do que em paciente classe II $(\mathbf{0 , 2 8} \mathbf{m m})$ (HART; TAFT; GREENBERG, 1992). 
$\mathrm{Na}$ literatura são relatados vários dispositivos que promovem a ancoragem, dentre eles, os mais utilizados são: a barra transpalatina (BORSOS et al., 2012; SHARMA; SHARMA; KHANNA, 2012), o arco lingual (MIOTTI, 1984; GIANELLY, 1995; OWAIS et al., 2010), o botão palatino de Nance (SHPACK et al., 2008), o arco transpalatino, o arco extra-bucal (BENSON et al., 2007) e mais atualmente, os miniimplantes (THIRUVENKATACHARI et al., 2006; BENSON et al., 2007; EL-BEIALY et al., 2009; THEBAULT et al., 2011; ARAÚJO et al., 2012; BORSOS et al., 2012), porém todos eles apresentam vantagens e desvantagens e nem sempre a ancoragem ideal é alcançada, principalmente os dispositivos que necessitam da colaboração do paciente.

A revisão sistemática conduzida por Feldman e Bondemark (2006), no qual foram compilados 489 artigos publicados entre janeiro de 1966 e dezembro de 2004, avaliando a efetividade dos sistemas de ancoragem, concluiu-se que, por causa da heterogeneidade dos protocolos de estudo e das conclusões contraditórias, nenhum resultado científico válido poderia ser estabelecido em relação à qualidade dos métodos de ancoragem descritos durante as fases de fechamento de espaço.

$O$ arco lingual tem sido utilizado para manter o comprimento do arco mandibular por meio da sua interferência no movimento mesial dos primeiros molares (GIANELLY, 1995), porém mesmo com o uso deste dispositivo, sem nenhuma força adicional nos molares, haverá perda de ancoragem, independente do calibre do fio que o aparelho foi confeccionado. Este fato foi observado no estudo de Owais et al. (2010) que verificaram sua eficiência comparando-se um grupo controle (grupo 3) com dois grupos experimentais que utilizaram arcos linguais confeccionados com fio de aço de dois calibres diferentes: $0,9 \mathrm{~mm}$ (grupo 1) e $1,12 \mathrm{~mm}$ (grupo 2) em pacientes com dentadura mista e indicação de extração de segundos molares decíduos. Os resultados demonstraram que houve uma perda de ancoragem em média de 1,4 para o grupo 1 e 1,53mm para o grupo 2, após um

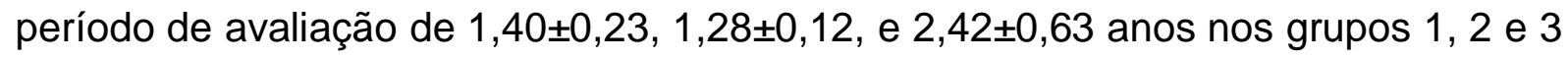
respectivamente.

Na mandíbula, a perda de ancoragem geralmente é menor do que na maxila, porque os molares são mais resistentes ao deslocamento mesial, ao passo que na maxila, o deslocamento mesial do primeiro molar ocorre mais rapidamente, e o problema pode tornar-se mais complexo. Isto é verdade, especialmente no tratamento da Classe II (XU et al., 2010). Para minimizar este problema, alguns 
autores tem indicado a retração da bateria anterior em duas etapas: primeiramente os caninos e posteriormente os quatro incisivos (GRABER; VANARSSALL, 1994; PROFFIT, 2002), porém Xu et al. (2010) num ensaio clínico randomizado piloto, avaliaram a eficácia relativa comparando-se a técnica da retração em massa com a técnica da retração em duas etapas. Foram utilizados como recurso de ancoragem a barra transpalatina ou o aparelho extra-oral, de acordo com a indicação do dentista responsável. Eles observaram que não houve diferenças estatisticamente significantes entre as duas técnicas de retração, sendo que a média de perda de ancoragem para os dois grupos foi de $4,3 \pm 2,1 \mathrm{~mm}$.

Já no estudo clínico randomizado de Sharma; Sharma e Khanna (2012) que também avaliaram a perda de ancoragem na retração inicial de canino, utilizando a barra transpalatina como ancoragem, observaram uma perda de ancoragem de 2,48mm em média.

Além do sistema de ancoragem, alguns autores defendem a premissa de que o tipo do design do bráquete pode influenciar na perda de ancoragem dos molares na fase de retração inicial de caninos, ou seja, quando o canino é distalizado até a seu contato com o segundo pré-molar utilizando-se bráquete Edgwise e fio retangular, haverá um movimento de corpo maior que o movimento pendular, portanto, uma maior perda de ancoragem, ao passo que a distalização do canino até seu contato com o segundo pré-molar utilizando-se bráquete Tip-Edge para posterior correção do torque, promoverá um movimento pendular maior que o de corpo e, portanto, uma menor perda de ancoragem (LOTZOF; FINE; CISNEROS, 1996; PARKHOUSE, 1998). Porém, Shpack et al. (2008) avaliando a média de perda de ancoragem dos molares na fase de retração dos caninos comparando-se a mecânica por deslizamento e movimento de corpo (bráquete Edgwise) com a mecânica de inclinação/verticalização (bráquetes Tip-Edge), utilizando como sistema de ancoragem, o botão palatino de Nance e a mecânica de retração em duas etapas com molas fechadas de NiTi, observaram que a perda de ancoragem para a mecânica de corpo foi em média $1,4 \mathrm{~mm}(+/-0,5 \mathrm{~mm})$ e para a mecânica com inclinação/verticalização, o valor encontrado foi em média 1,2mm (+/- 0,3mm), sem diferença estatisticamente significante entre as duas mecânicas.

Após a introdução do uso de mini-implantes como recurso de ancoragem, a literatura diverge no que concerne à afirmação de que os mini-implantes promoveriam ancoragem absoluta. No estudo de Liou, Pai e Lin (2004), foi 
observado que após nove meses de aplicação da força ortodôntica, houve uma extrusão e inclinação para frente dos mini-implantes de 1 a 1,5mm em $58 \%$ dos pacientes, concluindo-se que os mini-implantes são dispositivos de ancoragem estáveis, mas não se mantém imóveis quando submetidos à força ortodôntica.

Benson et al. (2007) num estudo clínico randomizado em pacientes possuindo má oclusão de classe II, comparando a perda de ancoragem na retração em massa com molas fechadas de NiTi, utilizando-se como recurso de ancoragem o miniimplante na rafe palatina comparado com o arco extra-bucal (100-120hs/semana, calibrado em 450 gramas por lado), observaram que a perda de ancoragem foi duas vezes maior no grupo da ancoragem convencional (média de $3,0 \pm 3,4 \mathrm{~mm}$ ) comparado com o grupo mini-implante (média 1,5 $\pm 2,6 \mathrm{~mm}$ ).

Lee e Kim (2011), num estudo semelhante ao de Benson et al. (2007), porém em pacientes biprotrusos classe I, utilizando os mini-implante na mucosa vestibular bilateralmente, comparado com o arco extra-bucal (12-14 horas/dia, calibrado em 350 gramas de cada lado) associado com a barra transpalatina, observaram que a perda de ancoragem no grupo mini-implante foi significantemente menor que 0 grupo ancoragem convencional, respectivamente na média de $\mathbf{0 , 2} \mathrm{mm}$ e $\mathbf{2 , 2} \mathrm{mm}$.

Apesar dos diferentes dispositivos de ancoragem existentes na literatura, todos eles permitem uma perda de ancoragem em maior ou menor proporção. Este fato pode ser influenciado por outros fatores como: grau de apinhamento, mecânica ortodôntica, idade ou lado da extração (direito ou esquerdo) (GERON et al., 2003).

\subsection{Tomografia computadorizada feixe cônico}

O diagnóstico por imagens tem passado por grandes transformações nos últimos anos, determinadas especialmente pela revolução tecnológica no campo da informática.

No contexto das técnicas radiográficas convencionais, um variado número de técnicas estáticas e bidimensionais (periapicais, panorâmicas, cefalométricas, etc) são empregadas para registrar a anatomia tridimensional da região bucomaxilofacial, o que resulta em uma das principais limitações, somado à sua deficiência para avaliação dos tecidos moles (QUITERO et al., 1999). Suas limitações se refletem na imagem obtida pela identificação de distorções, ampliações, superposições de 
estruturas anatômicas, perspectivas limitadas e falta de resolução quando a imagem bidimensional é utilizada para visualização de reabsorções radiculares (MAH; HUANG; CHOO, 2010).

Diferentemente das radiografias convencionais, que projetam em um só plano as estruturas atravessadas pelos raios- $x$, a tomografia computadorizada (TC) evidencia as relações estruturais em profundidade, mostrando as imagens do corpo humano "em fatias", o que possibilita enxergar todas as estruturas em camadas, principalmente dos tecidos mineralizados com uma definição admirável, permitindo a delimitação de irregularidades tridimensionalmente (GARIB et al., 2007). Além disso, o sistema é mais sensível na diferenciação dos tipos de tecido quando comparado com a radiografia convencional, de modo que diferenças entre tipos de tecidos podem ser mais claramente delineadas e estudadas. Por exemplo, a radiografia convencional pode mostrar tecidos que tenham uma diferença de pelo menos $10 \%$ em densidade; já a tomografia computadorizada pode detectar diferenças de densidades de $1 \%$ ou menos. Outra vantagem é a habilidade para manipular e ajustar a imagem, ou seja, possibilidade de ajuste de brilho, realce de bordos, contraste, aumento em áreas específicas e outros ajustes que a tecnologia digital permite (MOZZO et al., 1998).

\section{Dose de radiação}

As tomografias computadorizadas (TC) inicialmente foram desenvolvidas para aplicações médicas e devido à dose de radiação ser muito alta comparadas às radiografias $2 \mathrm{D}$, além do custo excessivo, seu uso rotineiro na odontologia tornouse injustificável (SCHMUTH et al., 1992; HEIMISDOTTIR; BOSSHARDT; RUF, 2005; ALQERBAN et al., 2011). Para resolver esta questão, a tomografia computadorizada do feixe cônico (TCFC) ou "cone beam" foi introduzido no mercado, especificamente para regiões de cabeça e pescoço, fornecendo imagens volumétricas tridimensionais similares às imagens médicas, porém com baixo custo e redução da exposição do paciente à radiação (KAU et al., 2005; ALQERBAN et al., 2011; SHEWINVANAKITKUL et al., 2011; CHANG et al., 2012), cerca de 1/6 da liberada pela TC tradicional, segundo os estudos de Mozzo (1998) ou até 12 vezes menos radiação, segundo Ludlow e Ivanovic (2008), com a nova geração de tomógrafos odontológicos. 
A dose de radiação da TCFC varia substancialmente em função da marca comercial do aparelho e suas especificações técnicas selecionadas durante a tomada, (LUDLOW et al., 2006), como: campo de visão (FOV: Field of View), tempo de exposição e miliamperagem (TORRES et al., 2010), porém quando se compara os níveis de radiação recebida pela TCFC com um dos protocolos ortodônticos que consta de panorâmica, telerradiografia lateral, radiografia oclusal e radiografias periapicais da boca toda ou da sua quase totalidade, o nível de radiação poderá ser maior nas radiografias convencionais (2D) (SCHOLZ, 2011).

A tabela 1 extraída do trabalho de Scholz (2011) descreve as doses mínimas e máximas de cada tipo de radiografia mais utilizadas na Ortodontia, bem como da TCFC e algumas radiografias e tomografias convencionais (TC) utilizadas na medicina.

Tabela 1. Interpretação da dosagem relativa / TCFC

\begin{tabular}{|c|c|c|}
\hline Exames Odontológicos & $\begin{array}{c}\text { Dose de } \\
\text { radiação } \\
\text { efetiva } \\
\boldsymbol{\mu S \mathbf { V } ^ { * }}\end{array}$ & $\begin{array}{l}\text { Radiação natural } \\
\text { equivalente a: }\end{array}$ \\
\hline Panorâmica & $3-11$ & Meio a um dia \\
\hline Telerradiografia lateral & $5-7$ & Meio a um dia \\
\hline Radiografia oclusal & 5 & Meio dia \\
\hline Radiografia interproximal & $1-4$ & Meio dia \\
\hline Radiografias periapicais (boca completa) & $30-170$ & $4-21 d$ \\
\hline ATM (série) & $20-30$ & $3-4 d$ \\
\hline $\begin{array}{l}\text { Tomografia Computadorizada do Feixe Cônico (TCFC) } \\
\text { Exames Médicos }\end{array}$ & $40-135$ & $4-17 d$ \\
\hline Raio X (tórax) & 100 & $10-12 d$ \\
\hline Mamografia & 700 & $88 d$ \\
\hline Tomografia Computadorizada convencional (TC) & 8000 & $1000 \mathrm{~d}$ \\
\hline
\end{tabular}

Por outro lado, quando se compara a dose de radiação da TCFC com o protocolo mínimo convencional de radiografias para fins ortodônticos (telerradiografia lateral + panorâmica), há uma maior exposição de radiação aos tecidos proporcionados pela TCFC. Este fato foi confirmado no estudo de Grunheid 
et al. (2012) que quantificou a radiação em pacientes fantasmas (crânios construídos com o mesmo número atômico e densidade de massa que é radiologicamente equivalente ao esqueleto humano) expostos a vários protocolos da nova geração iCAT de TCFC, comparando-os com a radiação quando os mesmos eram expostos à radiografia panorâmica e telerradiografia por meio de dosímetros termoluminescentes. As doses de radiação variaram de 64,7 - 69,2 $\mu \mathrm{Sv}$ na resolução padrão (tempo de varredura 8,9s); 127,3 - 131,3 $\mu$ Sv na alta resolução (tempo de varredura 17,8s) e 134,2 $\mu$ Sv para alta resolução com tempo de varredura de 26,9s. As doses efetivas para panorâmica digital e telerradiografia em norma lateral foram: 21,5 e $4,5 \mu \mathrm{Sv}$ respectivamente.

Recentemente, Lorenzoni et al. (2012) fizeram uma revisão sistemática da literatura no período de 1997 a março de 2011, cujo objetivo foi discutir a dose de radiação associada a radiografias simples, TCFC e TC na odontologia com foco especial em Ortodontia. As tomografias foram divididas de acordo com a dimensão do campo de visão (FOV) em: pequeno $(\leq 10 \mathrm{~cm})$, médio (entre 10 e $15 \mathrm{~cm}$ ) e grande $(>15 \mathrm{~cm})$ e os autores concluíram que:

1. Aumentos na quilovoltagem (KV), miliamperagem (mA), tempo de exposição e campo de visão (FOV) do tomógrafo, resultam num aumento da dose efetiva de radiação;

2. A dose efetiva para TC é maior que para TCFC ou radiografias convencionais;

3. Quando a série de radiografias periapicais da boca completa é realizada com aparelhos radiográficos de colimação circular, as doses de radiação são mais elevadas quando comparadas ao campo de visão (FOV) grande na TCFC, mas a dose pode ser reduzida se utilizado um aparelho radiográfico com colimação retangular. Apesar da qualidade de imagem, a TCFC não substitui as radiografias periapicais da boca completa. 


\section{Aplicações na Ortodontia}

$\mathrm{Na}$ Ortodontia, a utilização dos exames tomográficos auxilia no diagnóstico e planejamento de dentes impactados, principalmente os caninos (ALQERBAN et al., 2011); em casos difíceis nos quais a ancoragem deve ser incrementada com elementos adicionais, como implantes palatinos ou parafusos bicorticais, avaliando $o$ nível ósseo e checando a direção de inserção, ou ainda o registro dos defeitos no osso alveolar, no pré e pós tratamento, gerados pela movimentação dentária de corpo (translação) (GUNDUZ et al., 2004).

Além disso, a literatura relata outras aplicações da TC em Ortodontia, como: medições do exato diâmetro mesiodistal de dentes permanentes não irrompidos para avaliação da discrepância dente-osso na dentadura mista (NGUYEN; BOYCHUK; ORELLANA, 2011); avaliação volumétrica das medidas dentárias (WANG et al., 2011); avaliações cefalométricas (PECK et al., 2007; BOUWENS et al., 2011; SHEWINVANAKITKUL et al., 2011; TONG et al., 2012); avaliação da influência da movimentação ortodôntica com a densidade do osso alveolar (CHANG et al., 2012); avaliação do grau de reabsorção radicular de dentes adjacentes a caninos retidos (ALQERBAN et al., 2011) e principalmente avaliação da crista óssea alveolar (LUND; GRONDAHL; GRONDAHL, 2012) e reabsorção radicular pré e pós tratamento ortodôntico (CASTRO et al., 2012; LEITE et al., 2012; LUND et al., 2012; MAKEDONAS et al., 2012; NEVES et al., 2012).

Para esta revisão, nos atentaremos somente à acurácia das TCFC no que se refere à reabsorção radicular e avaliação da crista óssea alveolar e também como instrumento de avaliação de medidas cefalométricas, que é o foco do nosso estudo.

\section{Acurácia}

Os primeiros estudos sobre a acurácia das TCFC na região bucomaxilofacial apareceram em 2004 com o estudo de Kobayashi et al (2004) e Lascala, Panella e Marques (2004) e desde então várias outros trabalhos tem sido feito com a intenção de verificação da acurácia das TCFC e os fatores que podem interferir. Estes estudos já demonstravam que as tomografias ofereciam grande acurácia e precisão, ou seja, as mensurações obtidas das imagens geradas são absolutamente semelhantes em comparação com as medidas realizadas diretamente no objeto de estudo. 
Os estudos mais atuais utilizam como objeto de estudo crânios de cadáveres humanos (SUOMALAINEN et al., 2008; PATCAS et al., 2012) ao invés de objetos físicos e, devido a esta metodologia, os dados são mais confiáveis por refletirem melhor a condição clínica.

Um dos fatores que poderiam interferir na acurácia das tomografias é o tamanho da resolução da imagem, ou seja, o tamanho do voxel que é a menor unidade da imagem podendo variar de 0,5 a 20mm, e esta variável é ajustada de acordo com a estrutura que se quer escanear, pois quanto menor o voxel, maior o detalhamento da estrutura escaneada (GARIB et al., 2007).

Patcas et al. (2012), num estudo em cadáveres humanos verificaram a acurácia das TCFC com diferentes resoluções: alta resolução (voxel -0,125 mm voxel) e baixa resolução (voxel - 0,4mm). O esquema abaixo mostra as variáveis analisadas que foram mensuradas com paquímetros digitais (acurácia de 0,01mm) diretamente nas peças anatômicas comparados com as medidas digitais mensuradas com o software Exam Vision com as duas resoluções (figura 7E). Além disso, foram localizadas nas peças anatômicas fenestrações na tábua óssea vestibular de alguns incisivos e esta variável também foi analisada testando-se a acurácia das tomografias para a identificação desta irregularidade. (Figura 7 A, 7B, 7C e 7D)
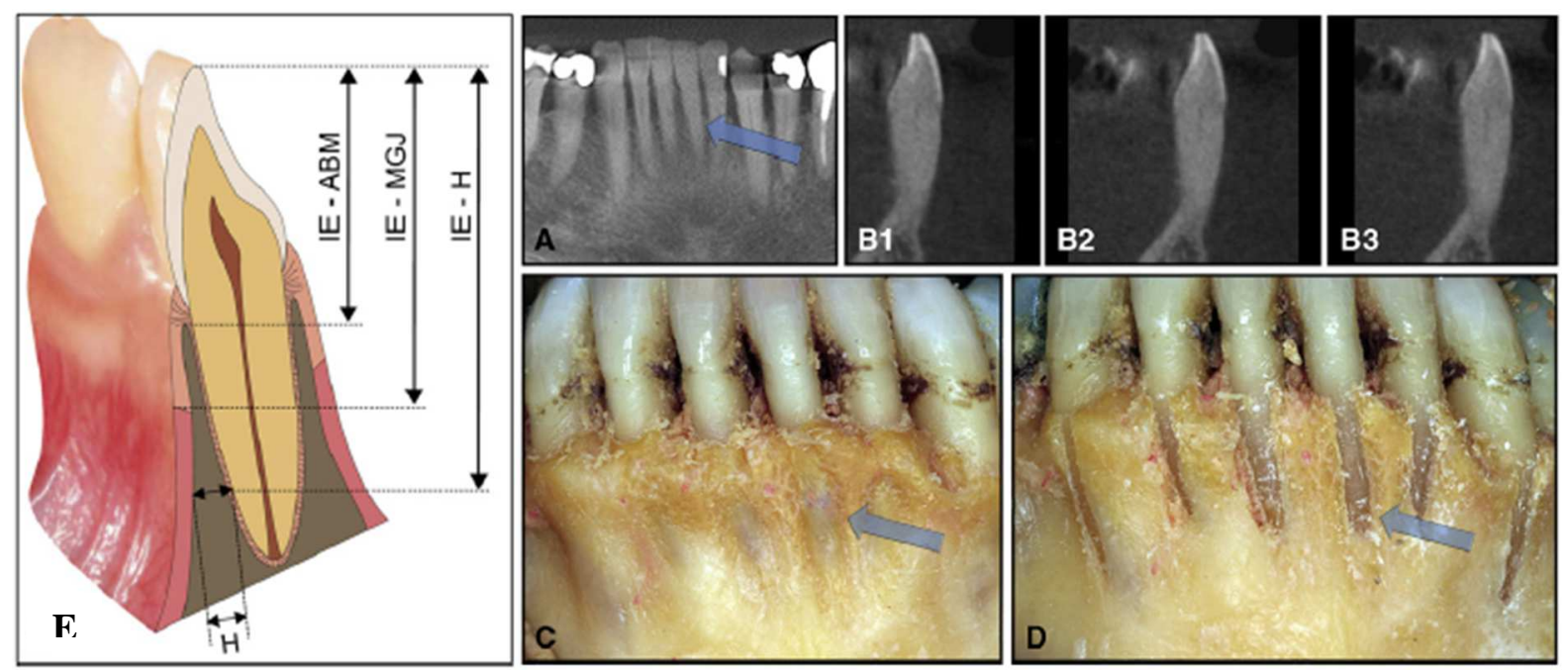

Figura 7. Em E: IE: borda incisal; ABM: crista óssea alveolar; MGJ: junção muco-gengival; H: medida horizontal. Em A: Tomografia - corte frontal; Em B: Tomografia - corte sagitais; C e D: Fenestrações nas peças anatômicas. 
Os resultados demonstraram que para as variáveis analisadas, exceto para fenestrações, não houve diferença estatisticamente significante entre as medidas físicas e virtuais, bem como não houve diferenças estatisticamente significativas quando comparadas as tomografias em alta e baixa resolução. Os dados sugerem que a TCFC mesmo com alta resolução não consegue detectar fenestrações, porém para avaliação de cristas marginais, ambas as resoluções são eficientes.

Uma das grandes vantagens das TCFC para avaliação da perda da crista óssea alveolar em relação às imagens radiográficas convencionais é a possibilidade de mensuração nos lados vestibular e lingual, além da mensuração da crista óssea mesial e distal que tanto a radiografia quanto a tomografia possibilitam.

Lund, Grondahl e Grondahl, (2012), num estudo em humanos, avaliaram a distância da crista óssea alveolar até a junção cemento-esmalte nas superfícies mesial, distal, vestibular e lingual dos incisivos e primeiros molares com TCFC no pré e pós tratamento, em um grupo de pacientes classe I com apinhamento severo e necessidade de extração de pré-molares. Os resultados mostraram que $84 \%$ da superfície lingual dos incisivos mandibulares apresentaram uma redução da altura óssea maior que $2 \mathrm{~mm}$. Em contrapartida, menos de $1 \%$ das faces proximais exibiram perdas ósseas maiores que $2 \mathrm{~mm}$. Os autores concluíram que a TCFC é de grande valia na determinação dos efeitos colaterais em longo prazo do tratamento ortodôntico, fornecendo informações precisas sobre a perda óssea da crista alveolar que não poderia ser detectado pelas radiografias convencionais.

A reabsorção radicular é também um efeito colateral do tratamento ortodôntico e uma preocupação constante, pois é assintomática, mesmo em casos de envolvimento pulpar, e seu diagnóstico precoce é fundamental para que não ocorra a perda do elemento dentário afetado (ALQERBAN et al., 2011). Sendo uma reação comum associado ao tratamento ortodôntico, mais comumente chamado de "custo biológico", a reabsorção radicular deve ser controlada e mensurada para que não ultrapasse os limites aceitáveis e, para sua quantificação, o que se tinha como ferramenta eram as imagens radiográficas $2 \mathrm{D}$, periapicais ou panorâmicas, porém com as limitações inerentes a elas.

Num estudo investigando a precisão do diagnóstico da radiografia panorâmica na detecção de reabsorções radiculares induzidas ortodonticamente, Dudic et al. (2009) mostraram que por meio da radiografia panorâmica, a reabsorção radicular 
apical foi diagnosticada em $44 \%$ dos dentes, enquanto que quando utilizada a TCFC, a reabsorção foi diagnosticada em $69 \%$ dos dentes.

Makedonas et al. (2012), investigaram por meio de TCFC a reabsorção radicular apical, após seis meses de tratamento ortodôntico em pacientes classe I tratados com extrações de pré-molares. Para isso, utilizaram os índices de Levander e Malmgren (1982) e concluíram que após 6 meses de tratamento a reabsorção foi diagnosticada somente em 4\% dos casos. Já Lund et al. (2012), num estudo semelhante ao de Makedonas et al. (2012) em relação à metodologia, observaram que após 6 meses, de todos os pacientes, 94\% tinham pelo menos um dente com encurtamento maior que $1 \mathrm{~mm}$ e 6,6\% tinham um ou mais dentes com encurtamento maior que $4 \mathrm{~mm}$, sendo que os dentes mais afetados em ordem decrescente foram: incisivos laterais, incisivos centrais e pré-molares.

Em relação às medidas cefalométricas lineares e angulares há uma unanimidade em se afirmar que as TCFC são mais precisas que os recursos convencionais, além da imagem ser mais nítida pelo fato de não haver sobreposições (PECK et al., 2007; BOUWENS et al., 2011; SHEWINVANAKITKUL et al., 2011; TONG et al., 2012).

Peck et al. (2007), verificaram a acurácia da TCFC em relação às radiografias panorâmicas no que concerne às angulações dentárias mesio-distais. Eles concluíram que as radiografias panorâmicas não fornecem informações confiáveis e precisas relacionadas à inclinação das raízes, principalmente nas regiões de caninos e pré-molares.

Bouwens et al. (2011) num estudo semelhante ao de Peck et al. (2007) concluíram que a radiografia panorâmica continua a ser um instrumento de rastreamento útil para a avaliação de dentes presentes e ausentes ou supranumerários, idade dental e seqüência de erupção, no entanto, as imagens panorâmicas fornecem informações menos confiáveis sobre angulações dentárias mesiodistais e podem apresentar desvios nas direções mesial e distal de todos os dentes.

Em relação às imagens 2D obtidas a partir de um tomógrafo iCAT, Lamichane et al (2009) avaliando a acurácia destas imagens em manequins desenvolvidos para este estudo, utilizando o programa Dolphin para obtenção dos cefalogramas frontal e lateral, observaram que os pontos e medidas lineares obtidas dos cefalogramas na projeção ortogonal não tiveram diferença significativa comparadas 
às medidas reais do manequim. Projeções ortogonais a partir de TCFC fornecem medidas médio-sagitais mais precisas do que projeções de perspectiva ou radiografias cefalométricas convencionais (KUMAR et al., 2007). Ludlow et al. (2009), comparando as imagens 2D geradas pela TCFC com radiografias convencionais em 20 pacientes pré-cirurgicos, constataram que as reconstruções multiplanares a partir da TCFC possibilitaram uma identificação mais precisa dos pontos cefalométricos tradicionais, principalmente quando há sobreposição de imagens, como por exemplo os pontos Condílio, Gônio e Orbitário. 


\section{Proposição}

"No meio da dificuldade encontra-se a oportunidade."

Albert Einstein 



\section{PROPOSIÇÃO}

O objetivo deste estudo consiste em avaliar a influência do laser em baixa intensidade (LBI) aplicado na unidade de ancoragem após movimentação ortodôntica com a seguinte dosimetria $\lambda=780 \mathrm{~nm} / \mathrm{P}=70 \mathrm{~mW} / \mathrm{DE}=105 \mathrm{~J} / \mathrm{cm} 2 / \mathrm{t}=60 \mathrm{~s} /$ ponto/Ep=4,2J/Et=67,2J, comparando o lado irradiado com o lado não irradiado para os seguintes eventos:

1. Deslocamento da unidade de ancoragem ortodôntica (molares e segundos pré-molares)

2. Sintomatologia dolorosa dos primeiros molares e segundos pré-molares

3. Nível da crista óssea e a reabsorção radicular dos primeiros molares e segundos pré-molares (unidade de ancoragem), bem como dos caninos que foram retraídos, com a intenção de verificação da integridade tecidual. 



\section{Material e Métodos}

"Penso noventa e nove vezes e nada descubro; deixo de pensar, mergulho em profundo silêncio - e eis que a verdade se revela."

Albert Einstein 



\section{MATERIAL E MÉTODOS}

\subsection{Material}

\subsubsection{Amostra}

Para realização deste trabalho, foram selecionados 21 indivíduos, de acordo com os seguintes critérios:

Critérios de inclusão:

a) Má-oclusão Classe I, segundo Angle, com indicação de extração dos primeiros pré-molares, devido à apinhamento dentário moderado ou biprotrusão, com possibilidade de perda de ancoragem;

b) Má-oclusão Classe II segundo Angle, com indicação de extração dos primeiros pré-molares superiores e de retração da bateria anterior, com possibilidade de perda de ancoragem;

c) Possuir perfil facial aceitável clinicamente para a indicação de extração de primeiros pré-molares;

d) Possuir todos os dentes permanentes já irrompidos, exceto os terceiros molares;

e) Não possuir doença sistêmica.

Critérios de exclusão:

a) Mordida cruzada anterior e/ou posterior;

b) Má-oclusão Classe III, segundo Angle;

c) Pacientes que por algum motivo tiveram que tomar drogas farmacológicas durante o período observacional;

d) Pacientes melanodermas ou de outros grupos étnicos que apresentassem manchas melânicas na mucosa da região de molares e segundos pré-molares. 


\subsubsection{Dados dos pacientes da amostra}

Este estudo foi aprovado pelo Comitê de Ética em Pesquisas da Faculdade de Odontologia de Bauru da Universidade de São Paulo, protocolo no. 133/2009 (anexo 2)

O cálculo do tamanho amostral foi feito com base no estudo de Cruz et al. (2004) que indicou uma amostra mínima de 12 pacientes, adotando-se um erro alfa de $5 \%$, um erro Beta de $1 \%$ e considerando o desvio-padrão do referido trabalho $(0,27 \mathrm{~mm})$ com uma diferença esperada entre as médias de 0,5mm. Contudo, prevendo possíveis perdas de pacientes durante a etapa experimental, adotou-se para este trabalho, uma amostra de 21 indivíduos.

Foram recrutados 222 pacientes e selecionados apenas 21 pacientes por meio de uma triagem realizada em duas escolas do município de Mauá - São Paulo. Dos 21 pacientes selecionados, 8 eram do gênero masculino e 13 do feminino, com idade mínima de 13 e máxima de 17 anos (média: 14,42 anos), sendo 16 pacientes portadores de má-oclusão Classe I de Angle e 5 pacientes portadores de má oclusão Classe II de Angle. Nos pacientes classe I de Angle foram utilizados os arcos dentários superior e inferior, totalizando 32 arcos dentários e para os pacientes classe II de Angle foram utilizados somente o arco superior num total de 5 arcos dentários. Obtivemos desta forma 37 arcos dentários totalizando, portanto, 72 molares, pré-molares e caninos avaliados. Todos os pacientes foram devidamente informados pela pesquisadora responsável (MVSS) sobre a realização da pesquisa e seu responsável assinou um termo de consentimento livre e esclarecido (anexo 3).

Para o diagnóstico e plano de tratamento ortodôntico, os pacientes foram encaminhados ao Departamento de Ortodontia da Universidade Metodista de São Paulo para a realização da documentação ortodôntica inicial, que constou de radiografia panorâmica, telerradiografia em norma lateral, fotos extra e intrabucais e modelos de estudo. As tomografias computadorizadas do feixe cônico foram obtidas nas fases inicial e final da retração dos caninos no centro de radiologia do Hospital da Face em São Paulo-SP. 
Foram avaliados os primeiros molares superiores e inferiores, num total de 74 dentes (37 pares), sendo 42 molares superiores (21 pares) e 32 molares inferiores (16 pares). Caso houvesse algum primeiro molar restaurado e esta restauração não estivesse com anatomia aceitável, esta era refeita de modo a poder ser facilmente identificada a fossa central (ponto de referência cap.4.2.5.).

As figuras 8 e 9 constam as fotografias extrabucais e intrabucais de um paciente selecionado neste estudo.

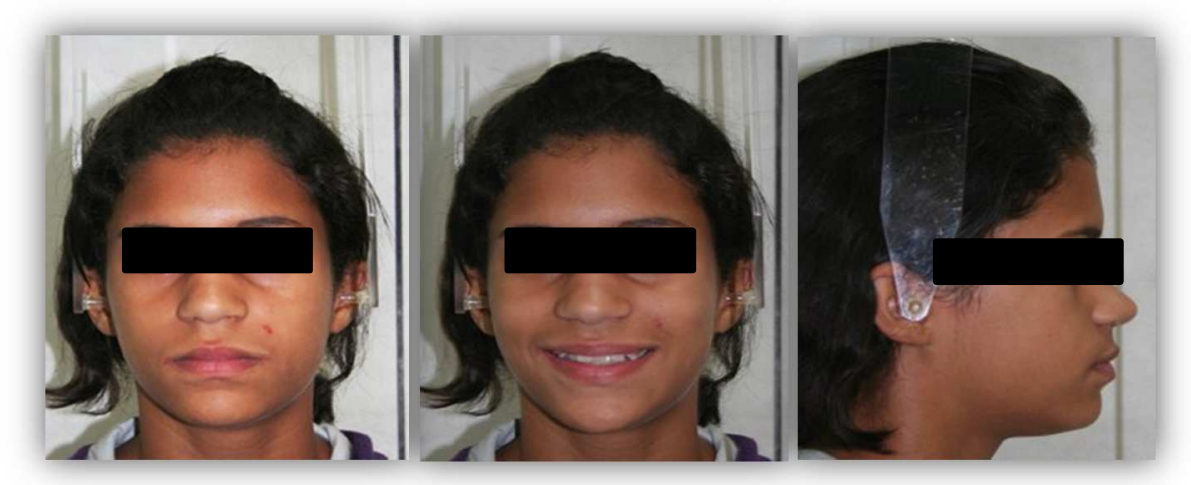

Figura 8 - Fotos extrabucais frontal, sorriso e lateral de um paciente selecionado para a amostra.

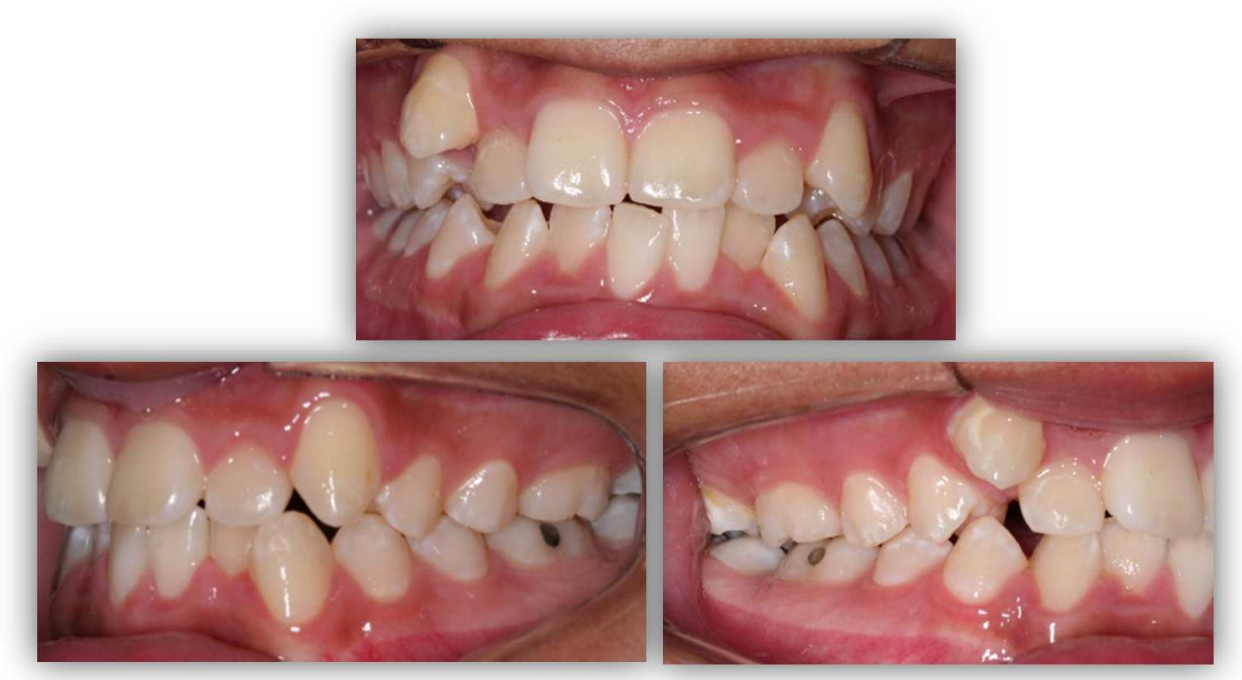

Figura 9 - Fotos intrabucais frontal, lateral esquerda e lateral direita de um paciente selecionado para a amostra. 


\subsection{Métodos}

\subsubsection{Tratamento ortodôntico}

Foram instalados bráquetes nos caninos e segundos pré-molares, de prescrição Roth, canaleta 0.022 × 0.028" (marca Morelli, Sorocaba, Brasil), e os primeiros molares foram devidamente bandados e os tubos triplos foram soldados. Então, foram solicitadas as extrações dos primeiros pré-molares que foram feitas bilateralmente, sendo sempre extraídos primeiramente os pré-molares do lado direito e depois, os pré-molares esquerdos, com intervalo de, no máximo, uma semana entre um lado e outro, sendo que a retração inicial dos caninos foi realizada após um mês de efetuadas as últimas extrações.

Depois de realizadas as extrações dentárias, previamente à retração inicial dos caninos, foram realizados levantes oclusais posteriores em resina fotopolimerizável nas cúspides mésio-vestibulares dos segundos molares inferiores bilateralmente para eliminação de possíveis contatos que pudessem interferir na movimentação dos caninos e desta forma solicitar mais do sistema de ancoragem (molares e pré-molares) (fig.10). Para aferição dos contatos dos caninos em oclusão foram utilizados tiras de poliéster. Considerava-se a altura do levante oclusal satisfatória quando na posição de máxima intercuspidação habitual fosse possível remover a tira de poliéster entre o canino superior e seu referido antagonista. Em seguida, realizou-se a moldagem do arco dentário superior e inferior com alginato para impressão e registro oclusal em cera, sendo que os moldes obtidos foram vertidos imediatamente com gesso pedra tipo IV (oclusal) e a sua base completada com gesso pedra tipo III. O registro interoclusal em cera serviu como um recurso a mais utilizado para verificar se havia alguma interferência oclusal que interferisse na retração inicial dos caninos.

Convém ressaltar que as moldagens e registro interoclusal foram efetuadas pelo mesmo profissional, nos tempos: T1 (início da retração de caninos), T2(após 30 dias de T1), T3 (após 60 dias de T1) e T4 (após 90 dias de T1), conforme quadro 3.

A seguir, os primeiros molares e segundos pré-molares foram conjugados com fio de amarrilho $0,030 \mathrm{~mm}$ e foram instalados arcos segmentados bilateralmente, confeccionado com fio de NiTi 0.016" conjuntamente a uma mola fechada de níquel-titânio de $7 \mathrm{~mm}$ (GAC), liberando uma força aproximada de $150 \mathrm{~g}$ 
para a retração inicial dos caninos (direito e esquerdo), conforme figura 10, mensurada por um dinamômetro (Morelli, Sorocaba, Brasil - 25 a 250gr). Estas molas que foram amarradas ao gancho do tubo dos primeiros molares até os bráquetes dos caninos com o auxílio de um fio de amarrilho 0,20mm (Morelli, Sorocaba, SP), foram reativadas de forma a gerar uma força de $150 \mathrm{~g}$, decorridos 30 e 60 dias (150g/lado).

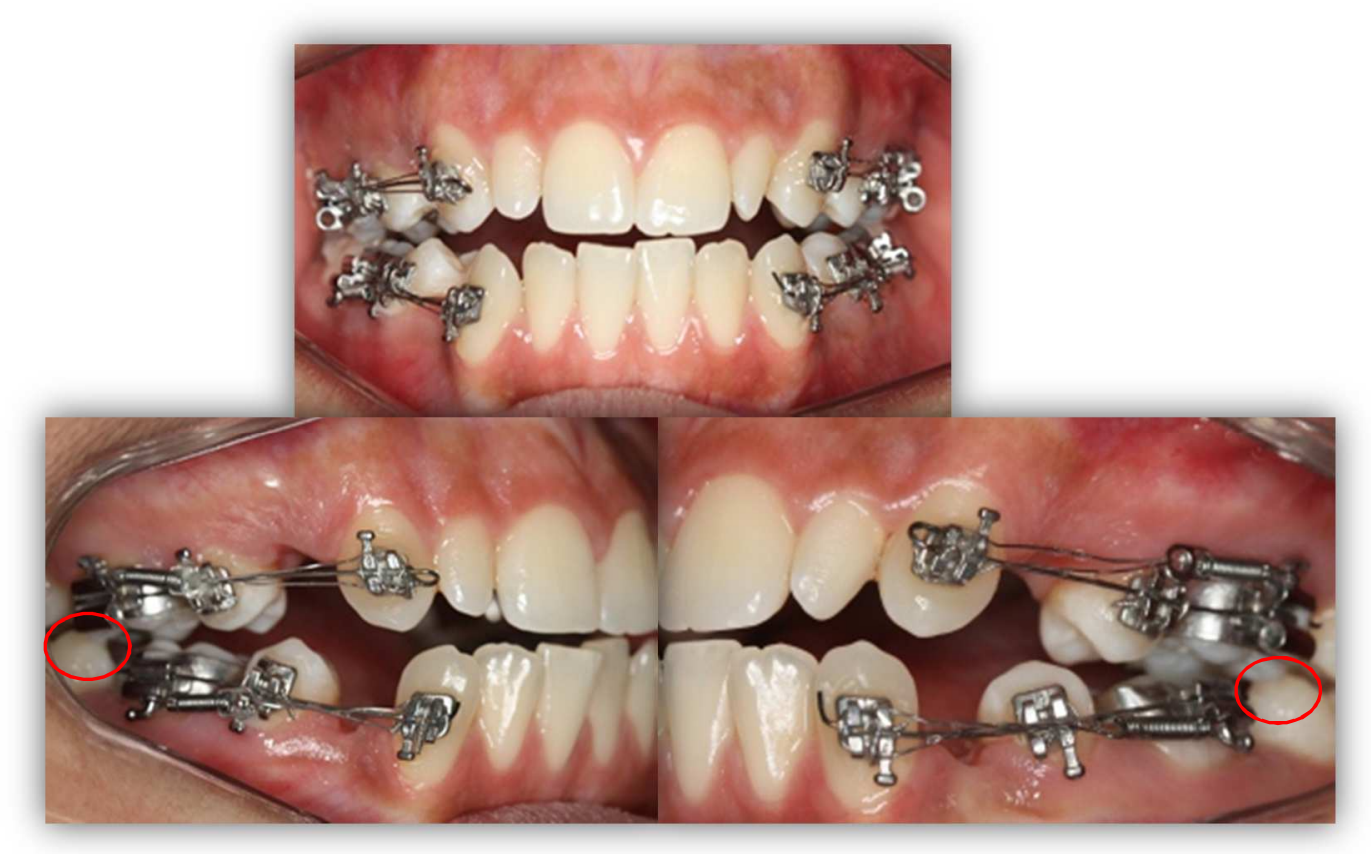

Figura 10 - Fotos intrabucais, frontal, lateral direita e lateral esquerda de um paciente selecionado para a amostra mostrando os arcos segmentados e a molas instaladas, como também o levante de mordida nas cúspides mesiais dos segundos molares inferiores (circulados).

Convém salientar, que não houve nenhuma movimentação ortodôntica prévia à instalação das molas de retração, nem nos molares e caninos, nem nos demais dentes do arco dentário. Isto se justifica para que não ocorram interferências de forças de outros dentes na movimentação dos molares e retração dos caninos, fato que pode ocorrer quando se utiliza um arco contínuo. Posteriormente, o laser foi aplicado randomicamente nos molares e pré-molares somente de um dos lados (direito ou esquerdo).

No caso de pacientes Classe I, onde os dois arcos dentários foram incluídos no experimento, se a unidade de ancoragem (molar/pré-molar) superior direita fosse eleita para ser irradiada, então a unidade de ancoragem oposta (inferior esquerda) era irradiada. O lado irradiado foi considerado grupo I e o não irradiado foi considerado grupo controle ou grupo não irradiado: grupo NI. 
Além disso, foram realizadas duas tomografias computadorizadas Cone Beam que foram obtidas nas fases inicial - início do tratamento (T0) e na fase final dos retração de caninos (T4), conforme quadro 3.

\subsubsection{Aplicação do laser}

O aparelho de laser utilizado foi o de diodo (Twin Laser, MMOptics, São Carlos, São Paulo) emitindo luz a um comprimento de onda de $780 \mathrm{~nm}$ (fig.11A) que foi previamente calibrado e aferido pela indústria produtora, conforme documento anexo 4.

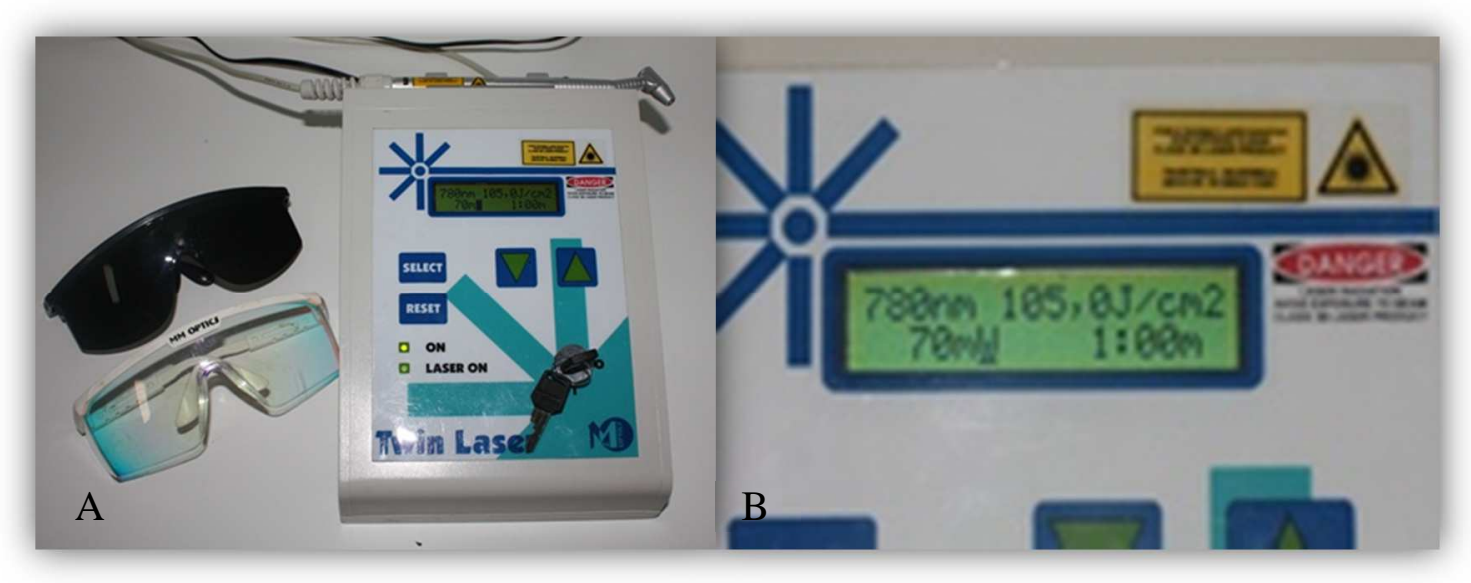

Figura 11- Aparelho de laser e visor ampliado com os parâmetros de aplicação programados

Para todos os pacientes foi utilizado o seguinte protocolo de aplicação: potência: $70 \mathrm{~mW}$, densidade de energia: $105 \mathrm{~J} / \mathbf{c m} 2$, tempo de 60 segundos por ponto (fig. 11B) resultando numa energia de 4,2J por ponto. Como foram 8 pontos por vestibular e oito por lingual, obtivemos um total de $67,2 \mathrm{~J}$ ao redor das raízes dos segundos pré-molares e primeiros molares (42J para os molares e $42 \mathrm{~J}$ para prémolares). Observe que os pontos 4 e 5 são comuns para os molares e os prémolares (fig. 12).

Sabe-se por meio da literatura que quando irradiamos um ponto, a área correspondente a $1 \mathrm{~cm} 2$ ao redor do ponto focal também recebe radiação (Colls, 1984), embora numa menor proporção, pois quanto maior a distância do ponto focal, menor a energia recebida pelos tecidos até o seu limite de extinção (Genovese, 2007). Como a área correspondente aos pontos 7 e 8 (região vestibular) e seus correspondentes por lingual estão dentro de uma área que abrange a região distal dos caninos, então os caninos foram considerados irradiados indiretamente. 
As irradiações foram feitas pelo mesmo operador onde o feixe de luz foi direcionado perpendicularmente e em contato com a mucosa, com a superfície limpa e seca, sendo necessária a utilização do isolamento relativo. Foram também tomados todos os cuidados necessários para a proteção do paciente e do operador, como o uso de óculos de proteção, bem como todos os cuidados de biossegurança necessários para a realização do procedimento, como por exemplo, aplicação de álcool 70 e colocação de barreiras descartáveis na ponta ativa do aparelho.

O laser foi aplicado nos seguintes pontos, conforme descrição e esquema abaixo (fig. 12):

1. gengiva marginal distal vestibular do primeiro molar;

2. a uma distância vertical de aproximadamente $7 \mathrm{~mm}$ do ponto 1 por vestibular e em direção ao ápice radicular;

3. um ponto vestibular central da raiz dentária do primeiro molar;

4. gengiva marginal mesial vestibular do primeiro molar ou gengiva marginal disto vestibular do segundo pré-molar;

5. a uma distância vertical de aproximadamente $7 \mathrm{~mm}$ do ponto 4 por vestibular e em direção ao ápice radicular;

6. um ponto vestibular central da raiz dentária do segundo pré-molar;

7. gengiva marginal mesial vestibular do segundo pré-molar;

8. a uma distância vertical de aproximadamente $7 \mathrm{~mm}$ do ponto 7 por vestibular e em direção ao ápice radicular.

Os mesmos pontos foram aplicados por lingual seguindo o mesmo protocolo acima descrito. 



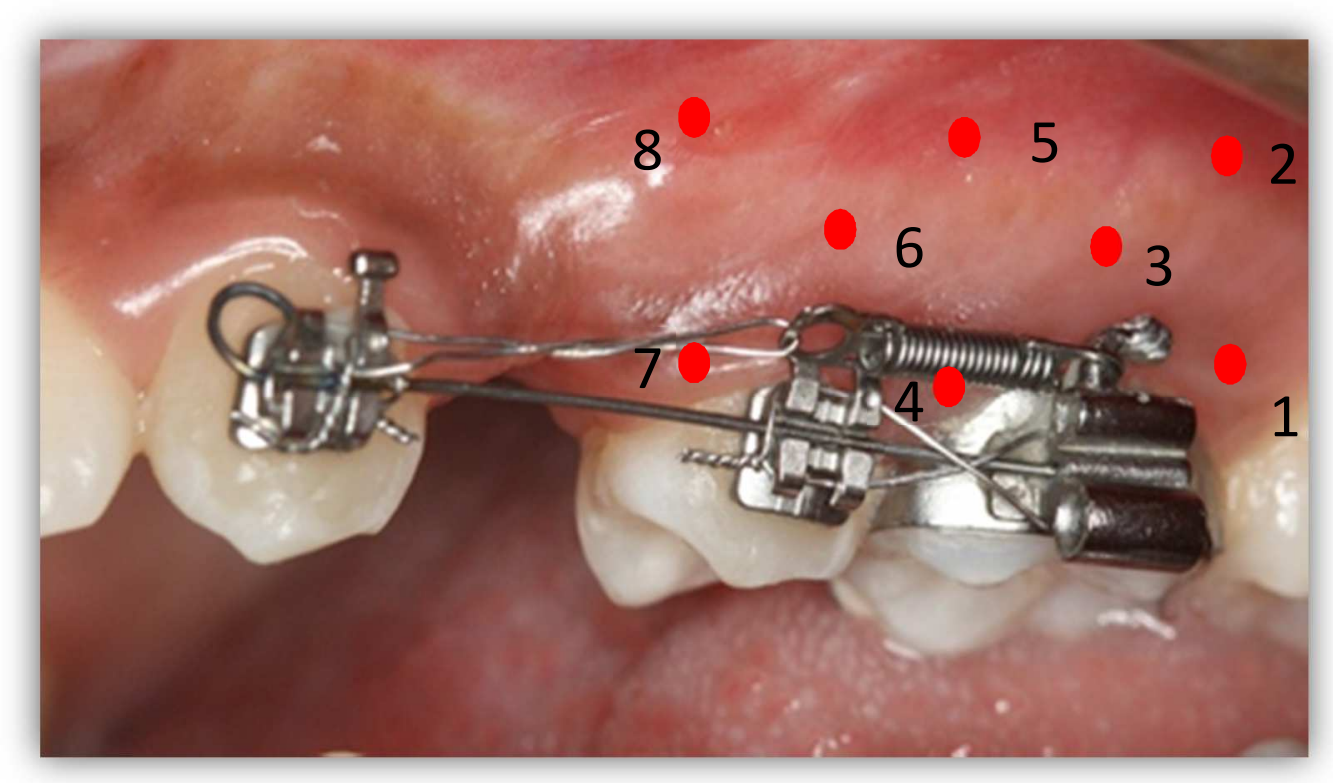

Figura 12. Pontos de aplicação do laser na região vestibular. Os mesmos pontos foram aplicados por lingual, num total de 16 pontos.

Esta aplicação do laser foi realizada imediatamente após a instalação das molas fechadas (T1), após 7 dias (T1-7 dias), 14 dias (T1-14 dias). No 30ํdia, as molas foram removidas, nova moldagem foi efetuada e as molas foram instaladas bilateralmente e reativadas ( $150 \mathrm{~g} /$ força para cada lado) e então, o laser foi aplicado somente no lado pré-determinado (lado irradiado - LI), imediatamente após a reativação das molas de $\mathrm{NiTi}$ (T2) (150 g/força para cada lado), seguindo-se nova aplicação após sete dias (T2-7 $7_{\text {dias }}$ ) e quatorze dias (T2-14 dias). Após 2 meses em média do início do ensaio clínico, as molas foram removidas novamente e nova moldagem efetuada. As molas foram novamente instaladas e reativadas $(150 \mathrm{~g} /$ força para cada lado) e o laser foi novamente reaplicado com o mesmo protocolo adotado nos meses anteriores, ou seja: imediatamente após a ativação das molas (T3), após sete (T3-7 $7_{\text {dias}}$ ) e após quatorze dias (T3-14 dias). Após 3 meses em média do início do ensaio clínico (T4), foi efetuada somente a moldagem (superior e inferior) e obtenção das tomografias finais, não sendo mais necessárias as aplicações com o laser (quadro 3). A partir daí, o tratamento ortodôntico dos pacientes transcorreu seguindo o planejamento já definido.

Vale salientar que a aplicação do laser foi realizada em somente um dos lados, nos segundos pré-molares e primeiros molares que serviram de ancoragem, sendo que no lado contralateral, foi apenas feita uma simulação, pois o paciente não era informado qual lado foi irradiado (estudo cego). A definição para o lado placebo 

(lado não irradiado - LNI) ou experimental (lado irradiado - LI) foi aleatória, ou seja, no dia da anamnese, para o primeiro paciente agendado, o lado irradiado foi escolhido pelo método de "cara ou coroa", por exemplo: para o primeiro paciente, o lado escolhido foi o direito; o próximo paciente que foi examinado automaticamente pertenceu ao grupo cujo lado irradiado foi o esquerdo e assim sucessivamente. Desta forma, os pré-molares e molares irradiados se alternaram aleatoriamente, em relação ao lado do arco dentário.

Quadro 3. Cronologia dos Procedimentos

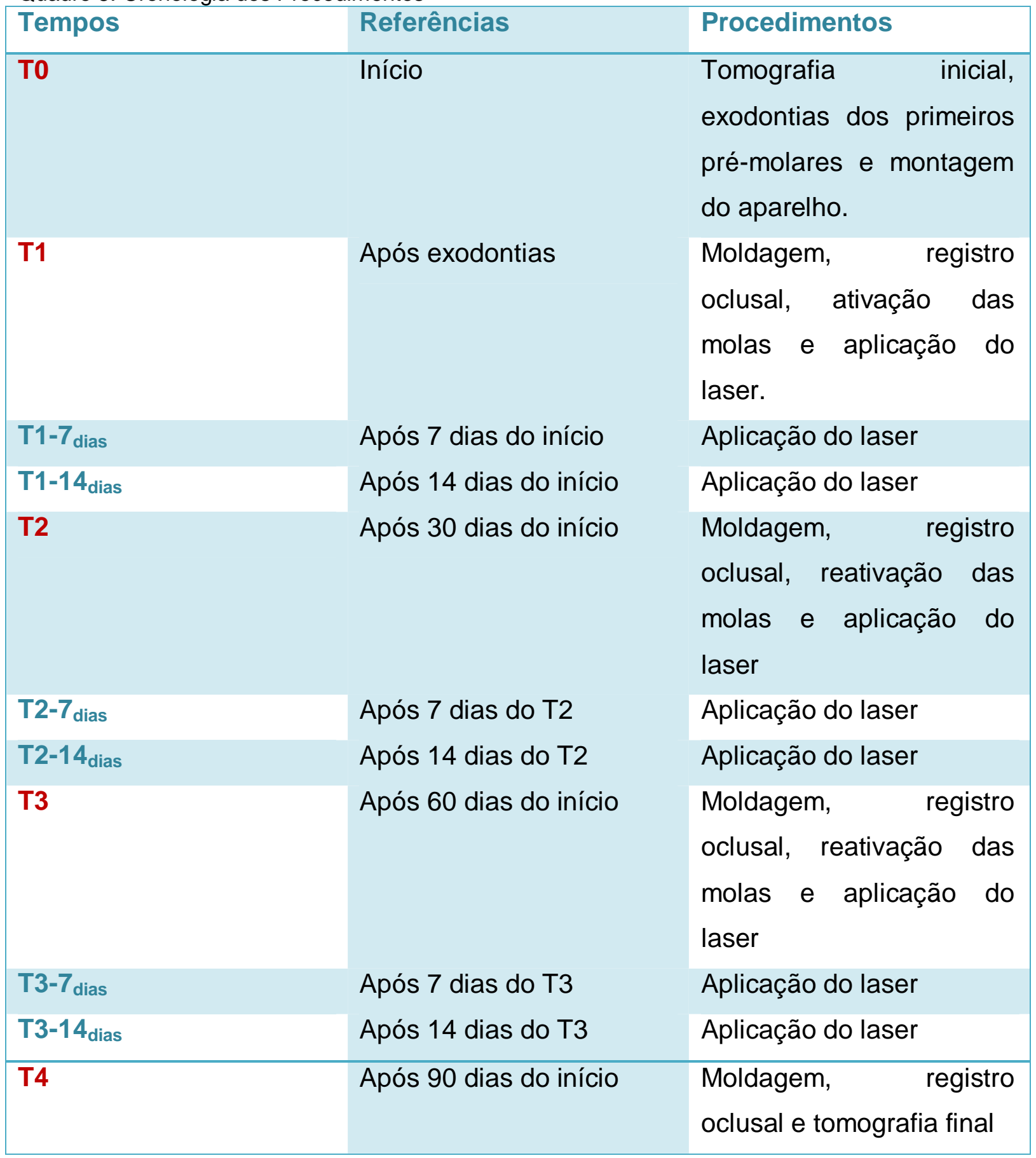




\subsubsection{Avaliação da sensibilidade dolorosa}

Foi avaliado o efeito analgésico após a instalação e ativação das molas de níquel-titânio, comparando-se a unidade de ancoragem irradiada ao seu contralateral não irradiado, em 12, 24, 48 e 72 horas após a aplicação do laser. Para essa avaliação, foi utilizada uma escala visual para análise gradual da sensibilidade dolorosa (Visual Analogue Scale - VAS) (LIM; LEW; TAY, 1995; TURHANI et al., 2006), onde o paciente assinalou de 0 a 10, em consonância com a intensidade de dor experimentada em ambos os lados, conforme ficha anexa. (anexo 5 e anexo 6).

Esta escala visual analógica foi entregue após cada ativação das molas durante os três meses em que o laser foi aplicado, sendo que o paciente a levava para casa e não sabia qual era o LI e o LNI. Como havia uma avaliação que deveria ser realizada após 12 horas, os pacientes eram atendidos somente no período da manhã. Os resultados foram então transferidos para uma planilha do Excel para análise estatística.

\subsubsection{Análise dos modelos}

Os modelos obtidos ao início (T1), após 30 (T2), 60 dias (T3) e após 90 dias (T4) foram avaliados com o intuito da obtenção das alterações sagitais do sistema de ancoragem (molares e pré-molares). Para isto, avaliou-se nos modelos, a extensão do deslocamento dos molares que foram mensurados por meio de um paquímetro digital (marca Mitutoyo, Japão), de precisão de 0,01mm (fig. 13A). Para isso, foram utilizados como pontos de referência tanto para os modelos superiores como para os inferiores, a fossa central dos primeiros molares de ambos os lados (pontos 1 e 2) e a região mais cervical da papila entre os incisivos centrais (ponto 3 ). Esta medida foi determinada como DPM, ou seja, a distância linear entre a papila e os primeiros molares do lado irradiado (DPMi) ou não irradiado (DPMni) (fig. 13B).

Estas medidas (distância 1-3 e 2-3) foram efetuadas pelo mesmo operador (MVSS) e o ponto 3 (papila incisiva) serviu como referência tanto para o lado irradiado como para o lado não irradiado.

Vale salientar que o operador (M.V.S.S.) não tinha ciência no momento da avaliação, qual era o dente irradiado ou não, caracterizando um estudo duplo cego, já que o paciente também não sabia qual era o lado irradiado. 


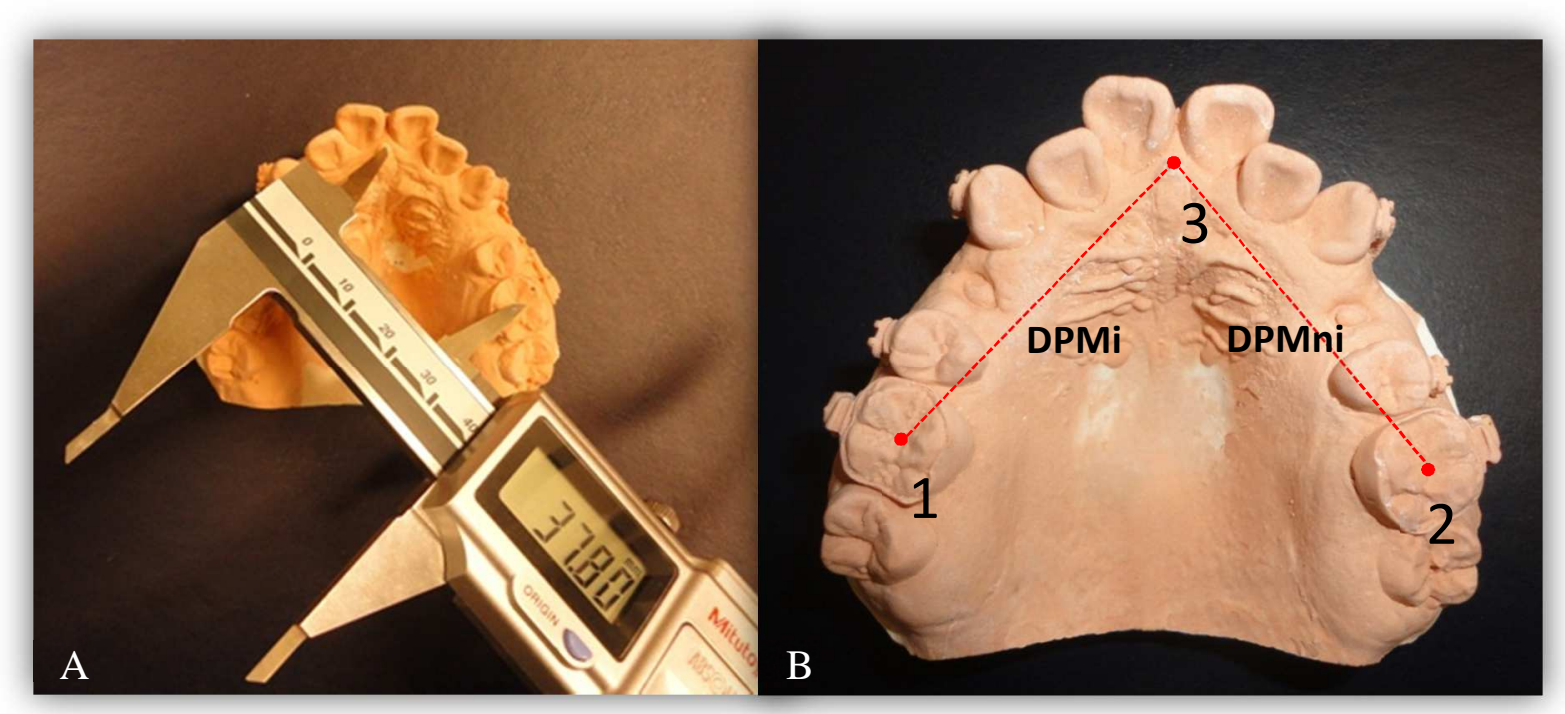

Figura 13. Em A, deslocamento dos molares mensurados por meio de um paquímetro digital e em $\mathrm{B}$, pontos de referência utilizados: ponto 1 e 2 , fossa central dos primeiros molares direito e esquerdo e ponto 3, papila entre os incisivos na sua porção mais central. DPMi: distância linear entre a papila e o primeiro molar do lado irradiado e DPMni: distância linear entre a papila e o primeiro molar do lado não irradiado

A distância percorrida pelos molares, medida em $\mathrm{mm}$, foi determinada pela diferença das distâncias mensuradas entre os tempos, ou seja, T2-T1, T3-T1, T4-T1, T3-T2, T4-T3. A distância total foi a diferença entre os tempos final e inicial: T4-T1.

\subsubsection{Análise cefalométrica nas tomografias}

\subsubsection{Obtenção da tomografia computadorizada do feixe cônico} (cone beam)

As tomografias computadorizadas do feixe cônico (TCFC) foram obtidas nos seguintes tempos: T0 e T4 (Quadro 3), de maneira padronizada no serviço de radiologia digital do Hospital da Face - São Paulo, por um único operador e por um único aparelho de tomografia computadorizada i-CAT® Cone Beam 3D (Imaging Sciences International, LLC - Hatfield, PA, USA).

O i-CAT utilizado para esta pesquisa possuía fonte de raio $X$ de $120 \mathrm{kVp}$ e 3-8 mAs (miliamperagem por segundo), sendo que o tempo de escaneamento foi de 40 segundos para face total, com resolução de 0,4mm (tamanho de voxel). 
Para a realização da tomografia, o paciente foi posicionado sentado, colocando um avental de chumbo, um suporte de cabeça e também um apoio mentoniano, de forma que seu plano sagital mediano ficasse coincidente com o feixe de luz da linha sagital mediana emitido pelo aparelho.

Após a realização da tomografia, o exame foi gravado em um DVD em formato DICOM.

\subsubsection{Obtenção das telerradiografias direita e esquerda}

As imagens DICOM foram então transportadas para o programa Dolphin Imaging 11.0 Premium (Imaging \& Management Solutions - CA - USA) onde a função "reconstrução 3D" foi selecionada. A partir desta imagem volumétrica foi obtida de cada paciente duas telerradiografias iniciais; direita e esquerda; e duas telerradiografias finais; direita e esquerda. A referência para individualizá-las foi a união do ponto násio com a espinha nasal anterior, traçado e identificado no plano sagital mediano(fig.14). Estas telerradiografias em norma lateral foram salvas em JPG e para cada paciente foi obtido 2 conjuntos de imagens: duas telerradiografias laterais direita (inicial e final) e duas telerradiografias laterais esquerda (inicial e final).

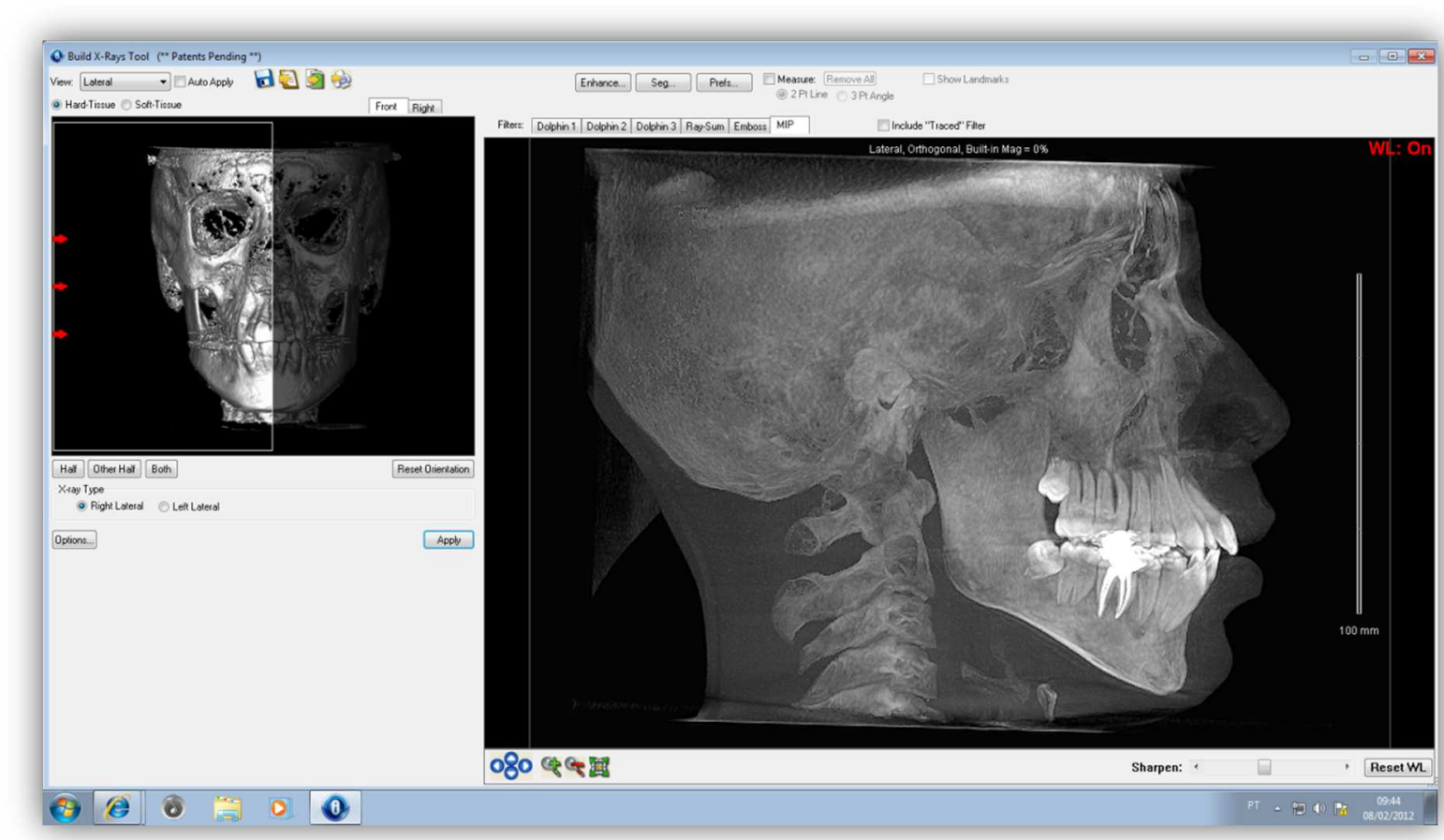

Figura 14. Obtenção da telerradiografia lateral direita a partir da imagem tridimensional no programa Dolphin. 
Estes conjuntos de imagens foram então transportados para o programa Radicef Studio 2 da empresa Radiomemory (Belo Horizonte, Brasil) que desenvolveu uma análise específica para esta tese, intitulada Análise 3D.

Antes, porém, as imagens foram devidamente calibradas utilizando a ferramenta do próprio programa Radiocef Studio2, marcando-se dois pontos de referência na régua já inserida no momento da realização da tomografia (lado direito da telerradiografia) pelo próprio programa e digitando-se a medida obtida no espaço correspondente à distância em milímetros (figura 15).

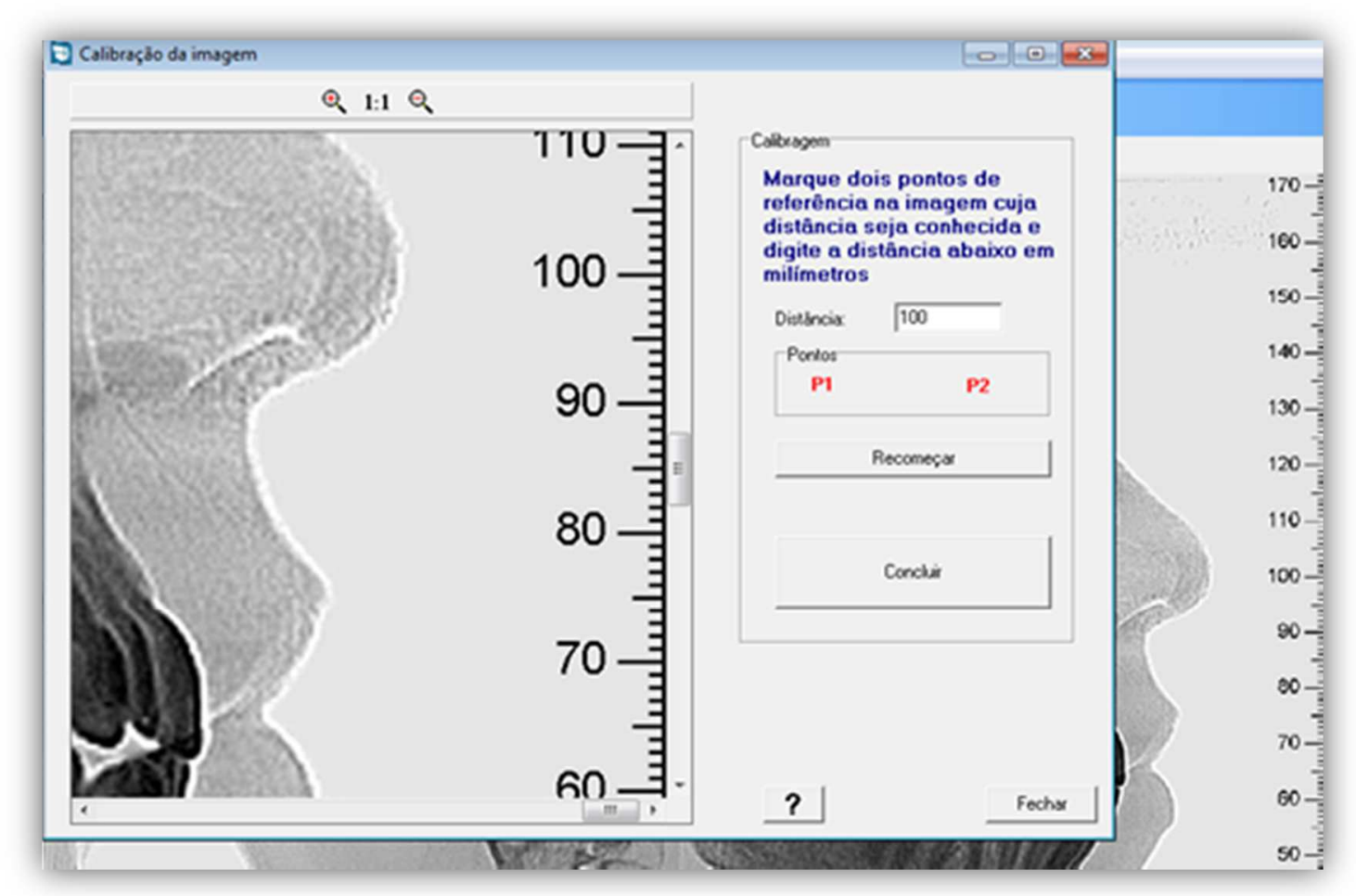

Figura 15 - Recurso para calibração da imagem no programa Radiocef Studio2.

Foram realizadas as medidas cefalométricas lineares e angulares nos molares que serviram de ancoragem e nos caninos que estavam sendo retraídos. Para comparação do LI com o LNI foram utilizadas as diferenças das medidas entre os tempos T0 (inicial) e T4 (final). 


\subsubsection{Pontos Cefalométricos}

Os pontos cefalométricos foram marcados no programa Radiocef Studio 2, nas quatro imagens correspondentes as telerradiografias. Os pontos cefalométricos marcados foram (figura 16):

- Pório (Po): ponto superior do meato acústico externo.

- Orbitário (Or): ponto inferior do contorno inferior da órbita.

- Pterigóideo (Pt): ponto superior e posterior da fossa pterigomaxilar.

- Gônio (Go): ponto póstero-inferior do ângulo mandibular.

- Mentoniano (Me): ponto inferior da sínfise mentoniana.

- M: ponto posterior da sínfise mandibular, perpendicular ao plano mandibular.

- Cúspide mésio-vestibular do primeiro molar superior direito (CMV16): ponto inferior da cúspide mésio-vestibular do primeiro molar superior direito.

- Ápice radicular da raiz mesial do primeiro molar superior direito (AMV16): ponto apical da raiz mésio-vestibular do primeiro molar superior direito.

- Cúspide mésio-vestibular do primeiro molar superior esquerdo (CMV26): ponto inferior da cúspide mésio-vestibular do primeiro molar superior esquerdo.

- Ápice radicular da raiz mesial do primeiro molar superior esquerdo (AMV26): ponto apical localizado na raiz mésio-vestibular do primeiro molar superior esquerdo.

- Cúspide mésio-vestibular do primeiro molar inferior esquerdo (CMV36): ponto superior da cúspide mésio-vestibular do primeiro molar inferior esquerdo.

- Ápice radicular da raiz mesial do primeiro molar inferior esquerdo (AMV36): ponto apical da raiz mésio-vestibular do primeiro molar inferior esquerdo.

- Cúspide mésio-vestibular do primeiro molar inferior direito (CMV46): ponto superior da cúspide mésio-vestibular do primeiro molar inferior direito.

- Ápice radicular da raiz mesial do primeiro molar inferior direito (AMV46): ponto apical da raiz mésio-vestibular do primeiro molar inferior direito.

- Canino superior direito (C13): ponto inferior da coroa do canino superior direito (ponta de cúspide). 
- Ápice radicular do canino superior direito (A13): ponto apical da raiz do canino superior direito.

- Canino superior esquerdo (C23): ponto inferior do canino superior esquerdo (ponta de cúspide).

- Ápice radicular do canino superior esquerdo (A23): ponto apical da raiz do canino superior esquerdo.

- Canino inferior esquerdo (C33): ponto superior da coroa do canino inferior esquerdo (ponta de cúspide).

- Ápice do canino inferior esquerdo (A33): ponto apical da raiz do canino inferior esquerdo.

- Canino inferior direito (C43): ponto superior da coroa do canino inferior direito (ponta de cúspide).

- Ápice do canino inferior direito (A43): ponto apical da raiz do canino inferior direito.

\subsubsection{Linhas e planos de referência}

As linhas e planos de referência são descritas e representadas na figura 16:

- Plano de Frankfurt: união dos pontos Po e Or.

- Plano mandibular: união do ponto Me com o ponto Go.

- Plano Pterigoideo Vertical (PTV/perp PoOr): plano que passa tangenciando a parte posterior da fossa pterigomaxilar, perpendicular ao Plano de Frankfurt.

- Linha MperpGoMe: linha que passa pelo ponto M perpendicular ao plano Mandibular.

- Linha L13: longo eixo do canino superior direito, passando pelos pontos C13 e A13.

- Linha L23: longo eixo do canino superior esquerdo, passando pelos pontos C23 e A23.

- Linha L16: longo eixo do molar superior direito, passando pelos pontos CMV16 e AMV16. 
- Linha L26: longo eixo do molar superior esquerdo, passando pelos pontos CMV26 e AMV26.

- Linha L43: longo eixo do canino inferior direito, passando pelos pontos C43 e A43.

- Linha L33: longo eixo do canino inferior esquerdo, passando pelos pontos C33 e A33.

- Linha L46: longo eixo do molar inferior direito, passando pelos pontos CMV46 e AMV46.

- Linha L36: longo eixo do molar inferior esquerdo, passando pelos pontos CMV36 e AMV36.

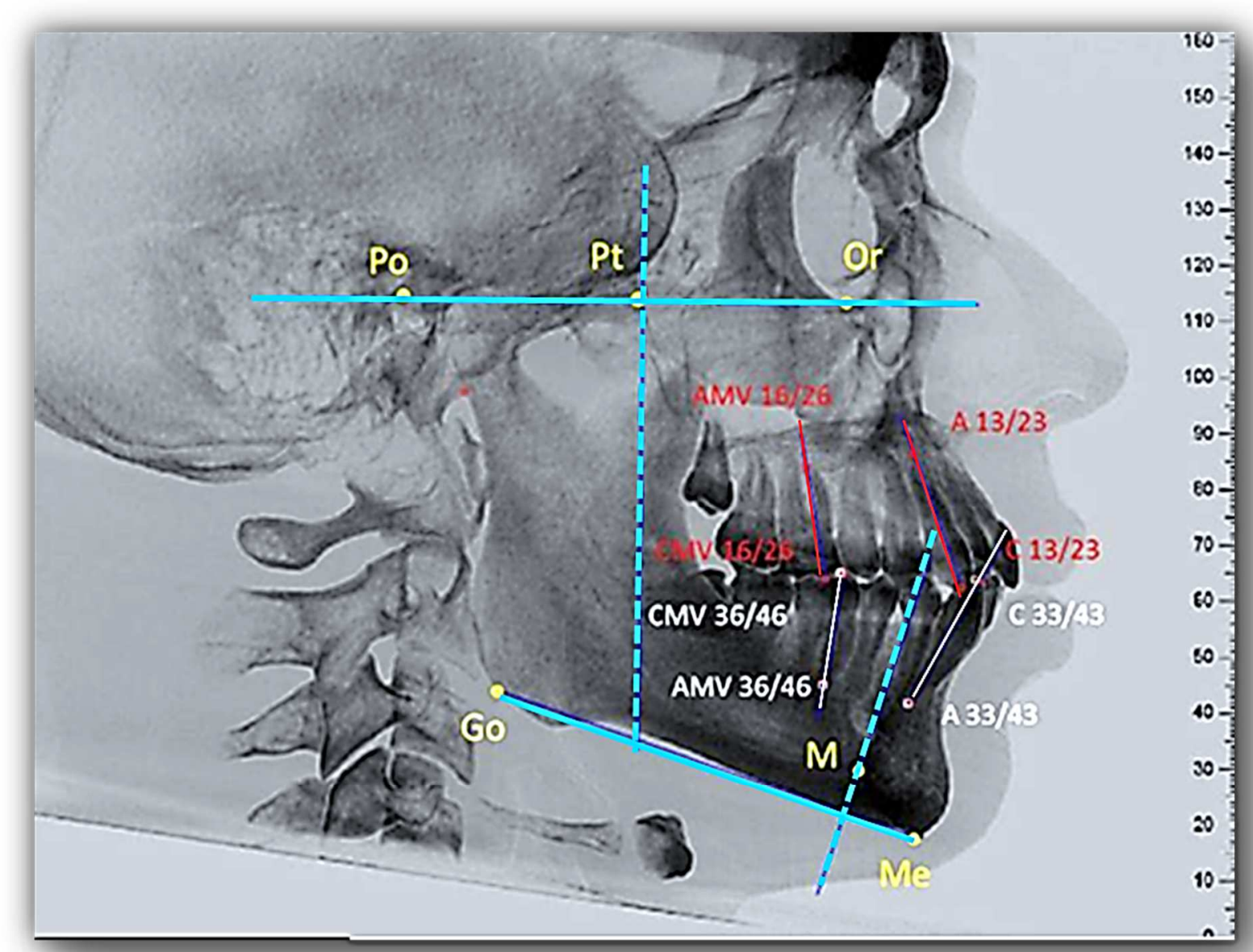

Figura 16: Pontos, linhas e planos de referência, exemplificado numa telerradiografia em norma lateral antes das extrações. 


\subsubsection{Variáveis analisadas nos molares}

Foram avaliadas as variáveis dos molares direito e esquerdo superiores e inferiores, sendo que, o molar do lado experimental (lado em que o molar foi irradiado) ora era do lado esquerdo, ora era do lado direito. As variáveis avaliadas foram:

\section{Ancoragem dos primeiros molares (Anc.M)}

As medidas lineares utilizadas na análise cefalométrica 3D foram (fig.17):

- Ancoragem do primeiro molar superior direito (Anc.16): medida linear (distância) da cúspide mésio-vestibular do primeiro molar superior direito (CMV16) até a linha PTV, paralelo ao plano de Frankfurt.

- Ancoragem do primeiro molar superior esquerdo (Anc.26): medida linear (distância) da cúspide mésio-vestibular do primeiro molar superior esquerdo (CMV26) até a linha PTV, paralelo ao plano de Frankfurt.

- Ancoragem do primeiro molar inferior direito (Anc.46): medida linear (distância) da cúspide mésio-vestibular do primeiro molar inferior direito (CMV46) até o seu ponto de encontro com a linha MperpGoMe, paralelo ao plano mandibular.

- Ancoragem do primeiro molar inferior esquerdo (Anc.36): medida linear (distância) da cúspide mésio-vestibular do primeiro molar inferior esquerdo (CMV36) até a linha MperpGoMe, paralelo ao plano mandibular.

Para o cálculo da perda de ancoragem nos molares (Anc.M) foi realizada a diferença entre os tempos: T0-T4, comparando-se a perda de ancoragem dos molares irradiados (Anc.MI) com os molares contralaterais (molar não irradiado Anc.MNI). 


\section{Angulação dos primeiros molares (Ang.M)}

As medidas angulares utilizadas foram (fig.17):

- Angulação do primeiro molar superior direito (Ang.16): ângulo interno, formado pelo longo eixo do primeiro molar superior direito (CMV16 AMV16) com o plano de Frankfurt (PoOr).

- Angulação do primeiro molar superior esquerdo (Ang.26): ângulo interno, formado pelo longo eixo do primeiro molar superior esquerdo (CMV26 - AMV26) com o plano de Frankfurt (PoOr).

- Angulação do primeiro molar inferior direito (Ang.46): ângulo posterior, formado pelo longo eixo do primeiro molar inferior direito (CMV46 AMV46) com o plano mandibular (Go - Me).

- Angulação do primeiro molar inferior esquerdo (Ang.36): ângulo posterior, formado pelo longo eixo do primeiro molar inferior esquerdo (CMV36 - AMV36) com o plano mandibular (Go - Me).

Para o cálculo da angulação dos primeiros molares (Ang.M), foi realizada a diferença entre os tempos: T0-T4, comparando-se a angulação das coroas dos molares irradiados (Ang.MI) com os molares não irradiados (Ang.MNI);

\subsubsection{Variáveis analisadas nos caninos}

\section{Retração dos caninos (Retr.C)}

As medidas lineares utilizadas na análise cefalométrica 3D foram (fig.17):

- Retração do canino superior direito (Retr.13): medida linear (distância) da cúspide do canino superior direito (C13) até o ponto de encontro com a linha PTV, paralelo ao plano de Frankfurt.

- Retração do canino superior esquerdo (Retr.23): medida linear (distância) da cúspide do canino superior esquerdo (C23) até o ponto de encontro com a linha PTV, paralelo ao plano de Frankfurt. 
- Retração do canino inferior direito (Retr.43): medida linear (distância) da cúspide do canino inferior direito (C43) até o ponto de encontro com a linha MperpGoMe, paralelo ao plano mandibular.

- Retração do canino inferior esquerdo (Retr.33): medida linear (distância) da cúspide do canino inferior esquerdo (C33) até o ponto de encontro com a linha MperpGoMe, paralelo ao plano mandibular.

Para o cálculo da quantidade de retração dos caninos foi realizada a diferença entre os tempos T4 e T0 do lado irradiado e do lado não irradiado.

\section{Angulação dos caninos (Ang.C)}

As medidas angulares utilizadas foram (fig.17):

- Angulação do canino superior direito (Ang.13): ângulo posterior formado pelo longo eixo do canino superior direito $(C 13 C-A 13)$ com o plano de Frankfurt (PoOr).

- Angulação do canino superior esquerdo (Ang.23): ângulo posterior formado pelo longo eixo do canino superior esquerdo (C23 - A23) com o plano de Frankfurt (PoOr).

- Angulação do canino inferior direito (Ang.43): ângulo posterior formado pelo longo eixo do canino inferior direito (C43 - A43) com o plano mandibular (GoMe).

- Angulação do canino inferior esquerdo (Ang.33): ângulo posterior formado pelo longo eixo do canino inferior esquerdo (C33 - A33) com o plano mandibular (Go Me).

Para o cálculo da angulação dos caninos, foi realizada a diferença entre os tempos T0 e T4 para ambos os lados: irradiado e não irradiado. 


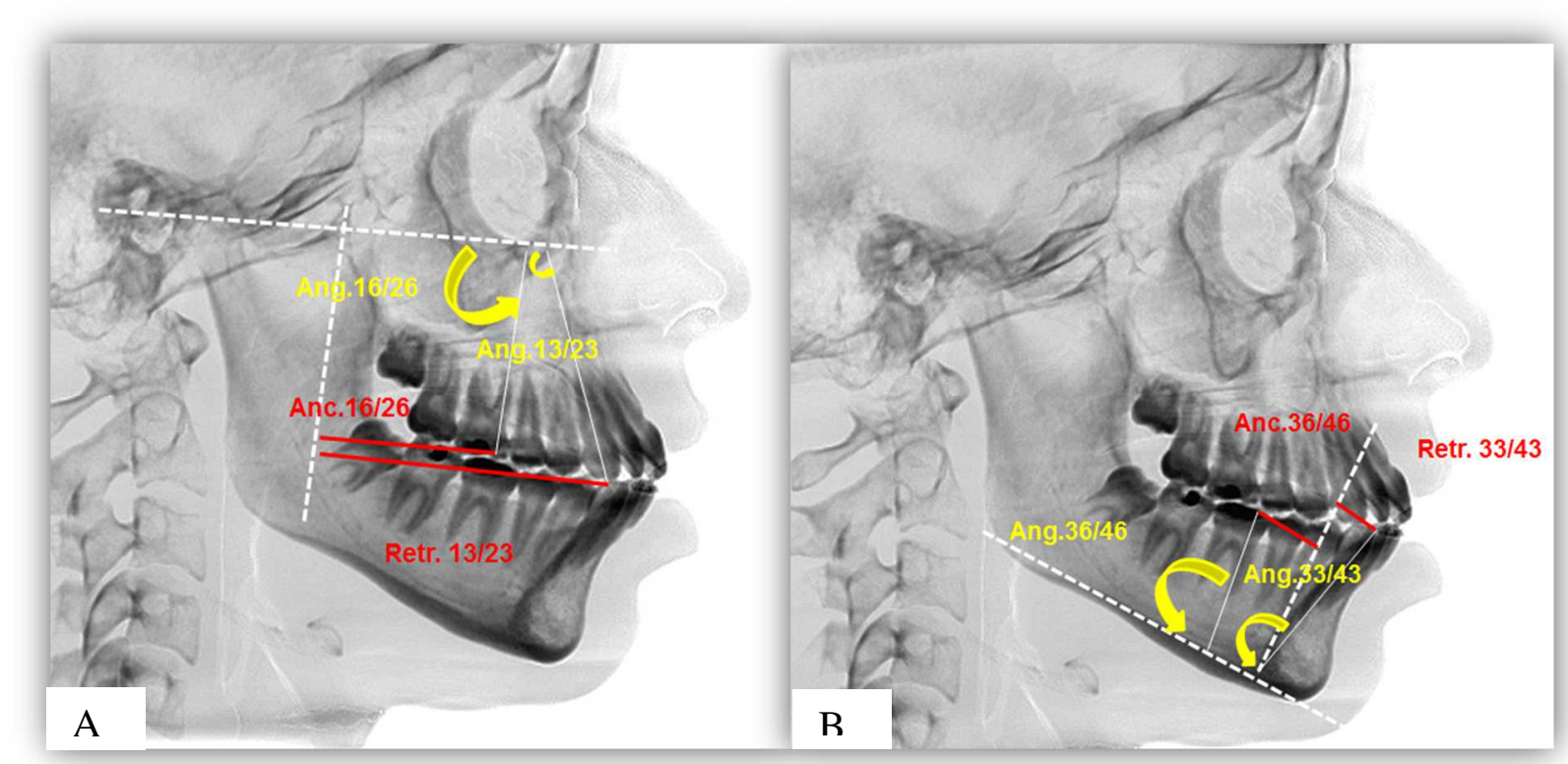

Figura 17. Em A, representação esquemática das medidas angulares e lineares nos molares e caninos superiores e em $B$, representação esquemática das medidas angulares e lineares nos molares e caninos inferiores.

\subsubsection{Avaliação da reabsorção radicular e crista óssea alveolar}

Nas tomografias (TCFC) obtidas nos tempos inicial (T0) e final (T4) foram avaliadas uma possível reabsorção óssea na crista alveolar nos caninos retraídos e nos dentes que serviram de ancoragem (primeiros molares e segundos prémolares), bem como a reabsorção radicular nestes referidos dentes. Para isso, foi utilizado o programa Dolphin Imaging 11.0 Premium (Imaging \& Management Solutions - CA - USA), selecionando-se a função "reconstrução 3D" e a partir daí, a possibilidade de aquisição dos cortes nos vários planos: axial, sagital e coronal, conforme figura 19. Vale salientar que o operador (M.V.S.S.) não tinha ciência no momento da avaliação, qual era o dente irradiado ou não, caracterizando um estudo duplo cego, já que o paciente também não sabia qual era o lado irradiado.

\subsubsection{Avaliação da reabsorção radicular}

Para avaliação da reabsorção radicular foi utilizado como referência a ponta de cúspide de cada dente com seu respectivo ápice radicular. A determinação do comprimento máximo linear entre ápice radicular e incisal /cúspide foi possível com a reconstrução multiplanar (sem volume) axial. 
Para a escolha do melhor corte, ou seja, aquele que apresentasse o dente no seu máximo comprimento linear utilizou-se como método a Navegação Axial Guiada (NAG) (CASTRO et al., 2012), que é o processo de criação de cortes a partir de um conjunto de dados volumétricos. Para isso, o cursor foi movimentado no plano axial (linha vermelha e verde da fig.18C) até a localização dos pontos de referência (ápice radicular e incisal/cúspide) na intersecção com o plano sagital (fig.18B) ou coronal (fig.18A)

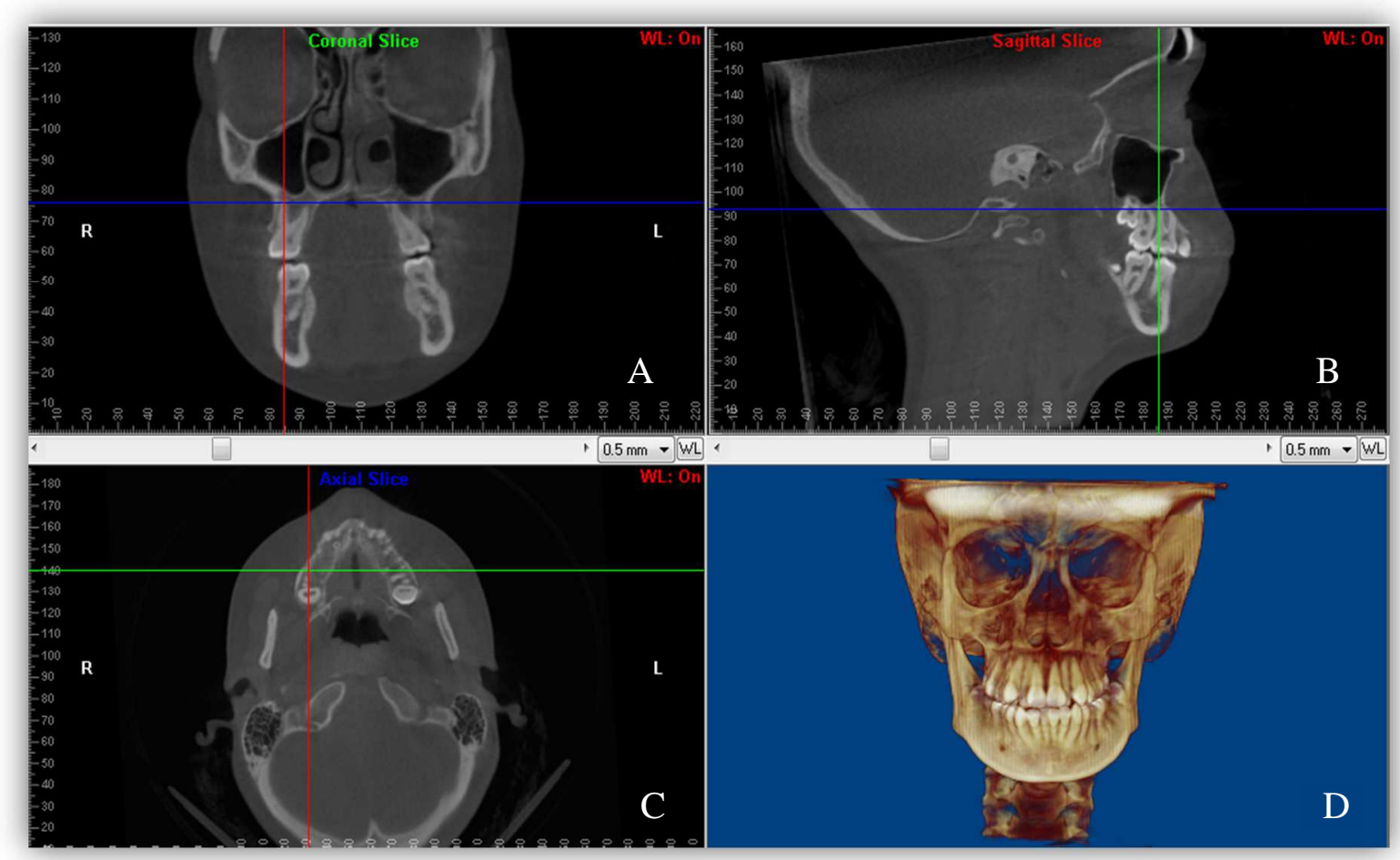

Figura 18. Reconstrução multiplanar: em A, plano coronal; em B, plano sagital; em C, plano axial e em $\mathrm{D}$, reconstrução 3D.

Demarcados os pontos de referência, traçou-se uma perpendicular (fig. 19) ao plano coronal ou sagital tangenciando os ápices radiculares e cúspides e a partir destas referências as medidas lineares do longo eixo do dente para cada raiz, puderam ser realizadas. Os pontos de referência para os dentes superiores utilizados no corte sagital foram: cúspide mesio-vestibular do primeiro molar até o ápice da raiz mesio-vestibular (fig.19A); cúspide disto vestibular até ápice da raiz disto-vestibular (fig.19A); incisal do canino até o ápice de sua raiz (fig.19C) e cúspide vestibular do segundo pré-molar até o ápice da raiz vestibular(fig. 19D). Para a raiz palatina do primeiro molar foi utilizado o corte coronal, cujos pontos de 
referência foram cúspide lingual até ápice da raiz palatina (fig.19B). Para os dentes inferiores, todas as medidas foram realizadas no corte sagital e os pontos de referência foram: incisal do canino até seu ápice radicular (fig.19E); cúspide mésio vestibular do primeiro molar inferior até o ápice da raiz mésio-vestibular (fig.19G); cúspide disto-vestibular do primeiro molar até o ápice da raiz disto-vestibular (fig.19F) e cúspide vestibular do segundo pré-molar inferior até seu ápice radicular (fig.19H).

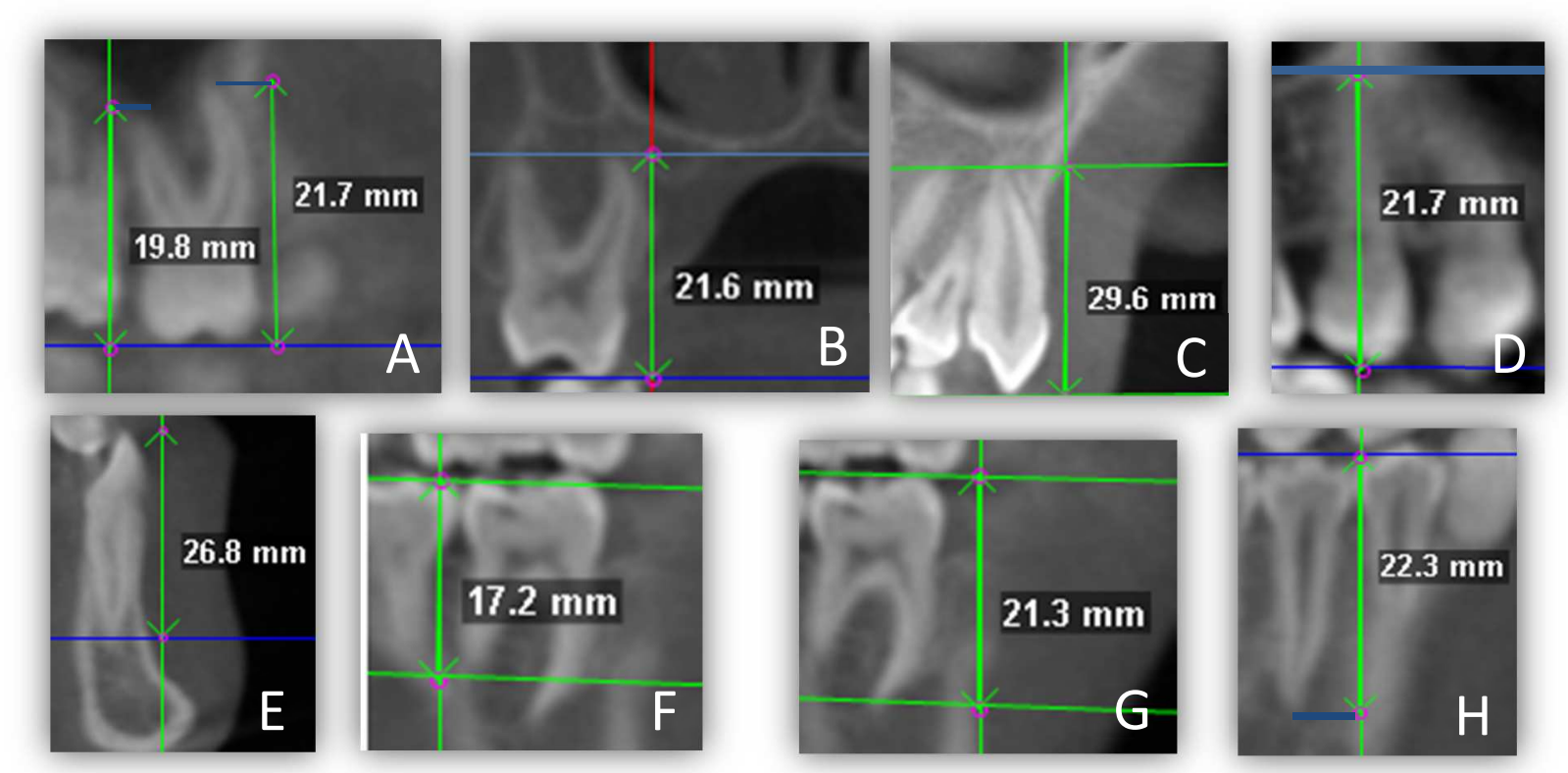

Figura 19. Pontos de referência e medidas lineares para as medidas do comprimento linear máximo. $\mathrm{Em} \mathrm{A}, \mathrm{C}, \mathrm{D}, \mathrm{E}, \mathrm{F}, \mathrm{G}$ e H , medidas realizadas no plano sagital e em $\mathrm{B}$, medidas realizadas no plano coronal.

As medidas foram efetuadas no tempo T0 e T4 e a diferença entre os tempos representou a quantidade de reabsorção radicular em $\mathrm{mm}$. A média destas medidas do lado irradiado e do lado não irradiado foram computadas numa tabela do Excel e comparadas.

\subsubsection{Avaliação da crista óssea alveolar}

As reconstruções geradas para a mensuração do comprimento do longo eixo do dente foram também utilizadas para avaliação da crista óssea alveolar. Pelo mesmo método da Navegação Axial Guiada (NAG) (CASTRO et al., 2012), 
selecionou-se o melhor corte que representasse o máximo comprimento linear de cada dente e a partir daí traçou-se um plano paralelo ao seu longo eixo e ao plano sagital e coronal, unindo as junções cemento-esmalte (JCE) à região mais elevada da crista óssea alveolar (CA) nos lados mesial, distal, vestibular e lingual (Figura 20). Tanto para os molares superiores e inferiores, como para os pré-molares superiores e inferiores, utilizou-se os planos sagital e coronal.

Verificou-se também a altura da crista óssea alveolar no plano sagital para os lados vestibular e lingual dos caninos retraídos, utilizando-se a mesma metodologia dos demais dentes avaliados (Fig. 20).

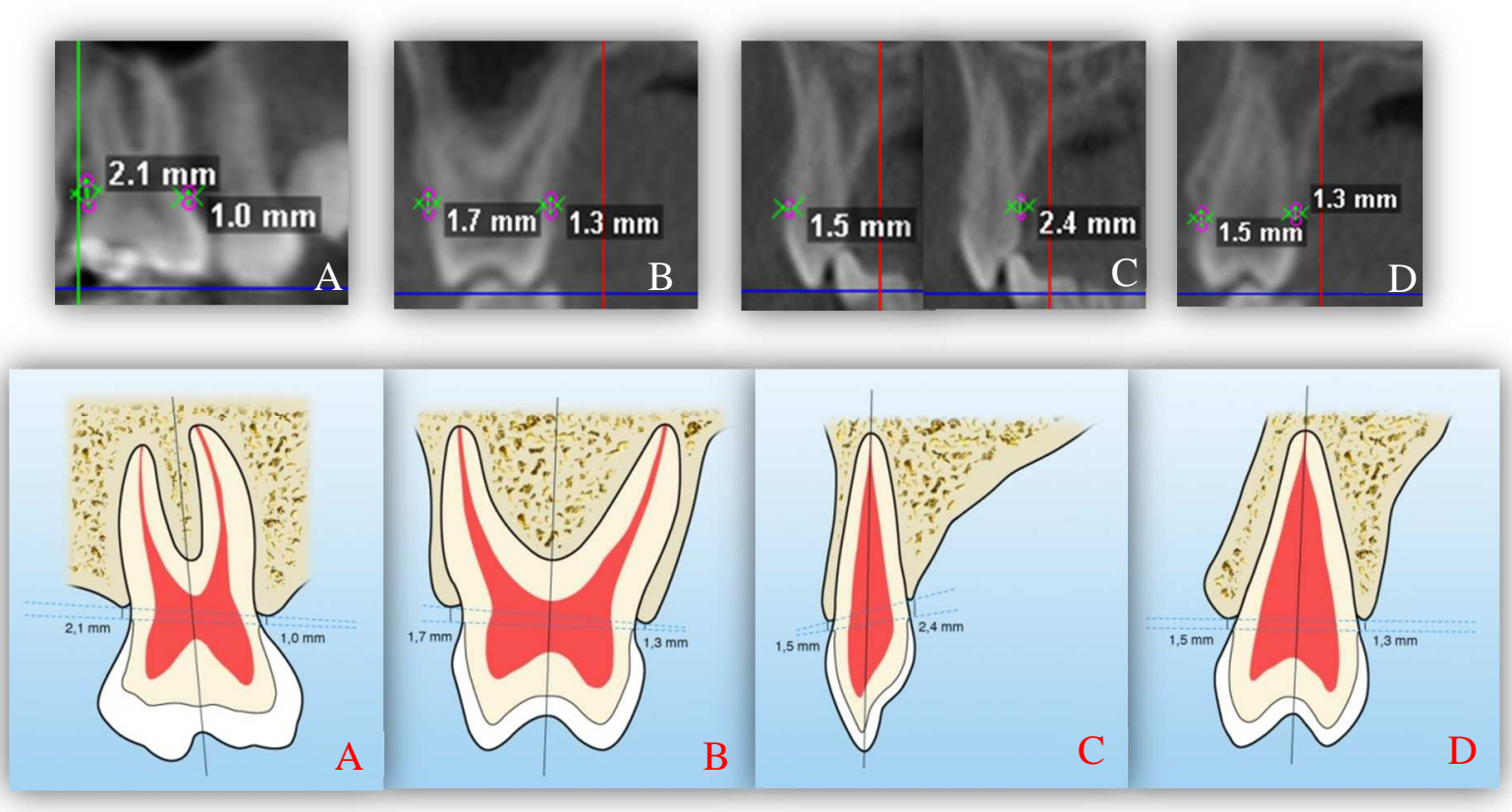

Figura 20. Exemplificação de algumas medidas da crista óssea alveolar (em $\mathrm{mm}$ ) com seu correspondente esquema abaixo: Em A, mesial e distal do primeiro molar superior (plano sagital); em $\mathrm{B}$, vestibular e lingual do primeiro molar superior (plano coronal); em $\mathrm{C}$, vestibular e ligual do canino superior (plano sagital) e em D, vestibular e lingual do segundo pré-molar superior (plano sagital).

As medidas obtidas foram registradas numa planilha do Excel e fez-se a diferença da distância JCE/CA (T4: tempo final - T0: tempo inicial) comparando-se o lado irradiado com o lado não irradiado para cada lado do dente analisado. 


\subsubsection{Avaliação da dor - análise estatística}

Para comparação entre os lados irradiados (LI) e não irradiados (LNI) avaliando-se a sintomatologia dolorosa nos períodos avaliados, foi utilizado o teste não paramétrico de Wilcoxon e para verificação da diferença da dor experimentada entre os tempos, utilizou-se o teste não paramétrico de Friedman.

Em todos os testes, o valor crítico adotado foi de $0.05(p<0,05)$.

Os procedimentos estatísticos foram executados no programa SigmaPlot 12.0 (Systat Software; Chicago, IL, USA) e Statistica 7 (StatSoft Inc; USA).

\subsubsection{Erro do Método}

Para a verificação do erro metodológico, foram aplicados tanto para as medidas analisadas nos modelos de gesso, quanto para as medidas obtidas na imagens tomográficas, a fórmula proposta por Dahlberg (1940), apud Houston (1983) para análise do erro casual, e do teste t de Student para dados pareados, para constatação de erro sistemático.

\subsubsection{Erro do método - modelos de estudo}

Foram remedidos 7 conjuntos de modelos ao início e final da retração dos caninos (4 modelos por paciente) totalizando 28 modelos, selecionados aleatoriamente, num período mínimo de 15 dias após a primeira medição. Assim, foram obtidos dois conjuntos de medidas para o mesmo paciente, realizados sob as mesmas condições, porém em tempos diferentes.

\section{Análise estatística}

Para comparar a quantidade de movimentação do lado irradiado (LI) comparado com o lado não irradiado (LNI), tanto para os arcos dentários superiores como para os arcos dentários inferiores, foi empregada a análise da variância (ANOVA) a dois critérios e ANOVA a um critério, seguido pelo teste de Tukey para 
avaliação da perda de ancoragem dos molares entre os tempos (T2-T1/T3-T2/T4T3). Em seguida, aplicou-se o teste "t" pareado para mensuração da diferença total entre os molares irradiados e os molares não irradiados (T4-T1).

\subsubsection{Erro do método - tomografias computadorizadas}

Foram medidas novamente 13 tomografias computadorizadas cone bem nas fases inicial (T0) e final da retração (T4) no programa Radiocef $3 D \AA$ que foram selecionadas aleatoriamente, num período mínimo de 15 dias após a primeira medição.

\section{Análise estatística}

Para comparação entre os tempos T0 (fase inicial) e T4 (fase final) da perda de ancoragem dos molares, alterações promovidas pela retração inicial dos caninos (angulação dos molares e caninos e quantidade de retração dos caninos), reabsorção radicular e crista óssea nas tomografias computadorizadas cone bem comparando-se o lado irradiado (LI) com o não irradiado (LNI), foi utilizado o teste "t" pareado. 



\section{Resultados}

"O mundo não está ameaçado pelas pessoas más, e sim por aquelas que permitem a maldade."

Albert Einstein 



\section{RESULTADOS}

\subsection{Análises do erro do método}

\subsubsection{Erro do método nos modelos de estudo}

A análise do erro nos modelos consta na tabela 2.

Tabela 2 - Erro do método nos modelos (medidas em mm); teste "t" pareado e fórmula de Dahlberg.

\begin{tabular}{|c|c|c|c|c|c|c|c|}
\hline \multirow[b]{2}{*}{ Variável } & \multicolumn{2}{|c|}{ 1a. Medição } & \multicolumn{2}{|c|}{ 2a. Medição } & \multirow[b]{2}{*}{$\mathrm{t}$} & \multirow[b]{2}{*}{$p$} & \multirow[b]{2}{*}{ Erro casua } \\
\hline & $\begin{array}{l}\text { Média } \\
(\mathrm{mm})\end{array}$ & $\mathrm{dP}$ & $\begin{array}{l}\text { Média } \\
(\mathrm{mm})\end{array}$ & $\mathrm{dP}$ & & & \\
\hline DPM & 33,75 & 3,56 & 33,78 & 3,58 & 0,71 & $0,478 \mathrm{~ns}$ & 0,3 \\
\hline
\end{tabular}

Observou-se que não houve erro sistemático e o erro casual foi de $0,3 \mathrm{~mm}$, de forma não relevante, quando da mensuração dos molares irradiados e não irradiados comparando-se a medida DPM (distância entre a região mais cervical da papila entre os incisivos centrais e a fossa central dos primeiros molares), nos modelos analisados.

\subsubsection{Erro do método nas tomografias computadorizadas}

A análise do erro do método nas tomografias computadorizadas encontra-se na tabela 3 e 4 
Tabela 3 - Erro do método das medidas dos lados irradiado e não irradiado realizadas nas tomografias computadorizadas cone beam $(\mathrm{mm})$ para mensuração da ancoragem dos molares, retração dos caninos e angulação dos molares e caninos - teste "t" pareado e fórmula de Dahlberg.

\begin{tabular}{|c|c|c|c|c|c|c|c|c|}
\hline \multirow{2}{*}{ Arco } & \multirow{2}{*}{ Variável } & \multicolumn{2}{|c|}{ 1ª. medição } & \multicolumn{2}{|c|}{ 2ª medição } & \multirow[t]{2}{*}{$\mathrm{t}$} & \multirow[t]{2}{*}{$p$} & \multirow[t]{2}{*}{ Erro } \\
\hline & & média & $\mathrm{dP}$ & média & $\mathrm{dP}$ & & & \\
\hline \multirow{3}{*}{ 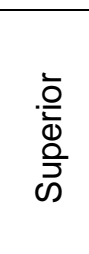 } & $\begin{array}{l}\text { Anc.Molar } \\
(\mathrm{mm})\end{array}$ & 27,75 & 4,60 & 27,82 & 4,35 & 0,79 & $0,44 n s$ & 0,25 \\
\hline & $\begin{array}{l}\text { Retr.Caninos } \\
(\mathrm{mm})\end{array}$ & 48,19 & 5,88 & 48,17 & 5,95 & 0,61 & $0,55 n s$ & 0,11 \\
\hline & $\begin{array}{l}\text { Ang.Molares } \\
\text { Ang.Caninos }\end{array}$ & $\begin{array}{c}87,77 \\
103,92\end{array}$ & $\begin{array}{l}7,83 \\
7,21\end{array}$ & $\begin{array}{c}87,68 \\
103,91\end{array}$ & $\begin{array}{l}7,74 \\
7,14\end{array}$ & $\begin{array}{l}0,99 \\
0,10\end{array}$ & $\begin{array}{l}0,34 n s \\
0,92 n s\end{array}$ & $\begin{array}{l}0,25 \\
0,29\end{array}$ \\
\hline \multirow{4}{*}{ 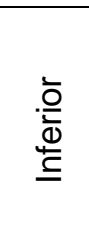 } & $\begin{array}{l}\text { Anc. Molar } \\
\text { (mm) }\end{array}$ & 14,13 & 2,36 & 14,13 & 2,31 & 0,02 & $0,98 \mathrm{~ns}$ & 0,17 \\
\hline & $\begin{array}{l}\text { Retr.Caninos } \\
(\mathrm{mm})\end{array}$ & 3,67 & 2,98 & 3,68 & 2,96 & 0,22 & $0,83 \mathrm{~ns}$ & 0,12 \\
\hline & Ang.Molares & 85,89 & 3,84 & 85,82 & 4,03 & 0,67 & $0,52 \mathrm{~ns}$ & 0,24 \\
\hline & Ang.Caninos & 91,20 & 6,47 & 91,09 & 6,49 & 0,78 & $0,45 n s$ & 0,33 \\
\hline
\end{tabular}

ns - diferença estatisticamente não significante

Tabela 4 - Erro do método das medidas realizadas nas tomografias computadorizadas cone beam $(\mathrm{mm})$ para reabsorção radicular e mensuração da crista marginal - teste "t" pareado e fórmula de Dahlberg.

\begin{tabular}{|c|c|c|c|c|c|c|c|c|}
\hline \multirow[t]{2}{*}{ variável } & & \multicolumn{2}{|c|}{ 1a. Medição } & \multicolumn{2}{|c|}{ 2a. Medição } & \multirow[t]{2}{*}{$\mathrm{t}$} & \multirow[t]{2}{*}{$p$} & \multirow[t]{2}{*}{$\begin{array}{c}\text { erro } \\
\text { casual }\end{array}$} \\
\hline & dente & média & $\mathrm{dP}$ & média & $\mathrm{dP}$ & & & \\
\hline \multirow{6}{*}{ 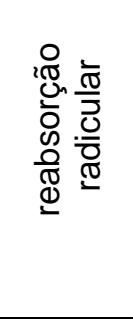 } & molar sup & 18,18 & 1,91 & 18,22 & 1,92 & 1,22 & $0,23 n s$ & 0,1 \\
\hline & molar inf & 19,25 & 1,91 & 19,27 & 1,88 & 0,43 & $0,67 n s$ & 0,08 \\
\hline & pré-molar sup & 18,64 & 1,31 & 18,65 & 1,39 & 0,22 & $0,82 n s$ & 0,11 \\
\hline & pré-molar inf & 21,27 & 1,91 & 21,28 & 1,87 & 0,24 & $0,81 \mathrm{~ns}$ & 0,1 \\
\hline & canino sup & 24,47 & 3,88 & 24,45 & 3,95 & 0,28 & $0,78 \mathrm{~ns}$ & 0,09 \\
\hline & canino inf & 24,9 & 2,13 & 24,92 & 2,03 & 0,54 & $0,60 \mathrm{~ns}$ & 0,09 \\
\hline \multirow{6}{*}{ 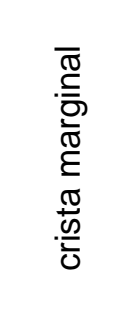 } & molar sup & 1,36 & 0,31 & 1,33 & 0,36 & 1,18 & $0,24 n s$ & 0,07 \\
\hline & molar inf & 1,28 & 0,62 & 1,28 & 0,61 & 0,18 & $0,85 n s$ & 0,07 \\
\hline & pré-molar sup & 1,48 & 0,49 & 1,49 & 0,53 & 0,43 & $0,67 n s$ & 0,09 \\
\hline & pré-molar inf & 1,53 & 0,55 & 1,55 & 0,6 & 0,88 & $0,38 \mathrm{~ns}$ & 0,09 \\
\hline & canino sup & 2 & 0,84 & 1,97 & 0,86 & 1 & $0,33 n s$ & 0,08 \\
\hline & canino inf & 1,8 & 0,44 & 1,77 & 0,45 & 1 & $0,33 \mathrm{~ns}$ & 0,08 \\
\hline
\end{tabular}

ns - diferença estatisticamente não significante

Observou-se que não houve erro sistemático e o erro casual foi de 0,11 a $0,07 \mathrm{~mm}$ de forma não relevante na mensuração das variáveis nas tomografias computadorizadas cone beam. 


\subsection{Avaliação da dor experimentada sob a influência do laser}

O presente estudo quantificou o nível de dor experimentada na unidade de ancoragem comparados com os contralaterais não irradiados, após 12h, 24h, 48h e $72 \mathrm{~h}$ da ativação das molas, por três meses consecutivos.

A tabela 5 descreve a média e desvio padrão obtida em todos os tempos avaliados (12h, 24h, 48h e 72h) mês a mês para o lado irradiado (LI) e não irradiado(LNI).

Tabela 5 - Descrição da média, desvio padrão e valores de $p$ (em vermelho quando significante) em todos os tempos avaliados do primeiro ao terceiro mês - lado irradiado (LI) e lado não irradiado (LNI)

\begin{tabular}{|c|c|c|c|c|c|c|c|c|c|c|c|c|}
\hline \multirow[t]{3}{*}{ Períodos } & \multicolumn{12}{|c|}{ Tempos } \\
\hline & 1 & $2 \mathrm{~h}$ & & 24 & & & $4 \varepsilon$ & $8 \mathrm{~h}$ & & 72 & $2 \mathrm{~h}$ & \\
\hline & $\begin{array}{c}\text { Média } \pm \text { dP } \\
\text { LI }\end{array}$ & $\begin{array}{c}\text { Média } \pm d P \\
\text { LNI }\end{array}$ & $p$ & $\begin{array}{c}\text { Média } \pm d P \\
\text { LI }\end{array}$ & $\begin{array}{c}\text { Média } \pm d P \\
\text { LNI }\end{array}$ & $p$ & $\begin{array}{c}\text { Média } \pm d P \\
\text { LI }\end{array}$ & $\begin{array}{c}\text { Média } \pm d P \\
\text { LNI }\end{array}$ & $p$ & $\begin{array}{c}\text { Média } \pm d P \\
\text { LI }\end{array}$ & $\begin{array}{c}\text { Média } \pm d P \\
\text { LNI }\end{array}$ & $\mathrm{p}$ \\
\hline 1‥ mês & $1,7 \pm 1,4$ & $3,2 \pm 1,7$ & $0,0^{*}$ & $0,9 \pm 1,2$ & $5,3 \pm 2,2$ & $0,0^{*}$ & $0,6 \pm 1,0$ & $4,3 \pm 1,7$ & $0,0^{*}$ & $0,1 \pm 0,4$ & $0,3 \pm 0,7$ & 0,08 \\
\hline 2. mês & $1,4 \pm 1,6$ & $2,3 \pm 1,8$ & $0,0^{*}$ & $0,8 \pm 1,4$ & $4,8 \pm 2,0$ & $0,0^{*}$ & $0,3 \pm 0,7$ & $3,3 \pm 1,9$ & $0,0^{*}$ & $0,2 \pm 0,6$ & $0,5 \pm 0,8$ & 0,10 \\
\hline 3․ mês & $2,5 \pm 1,9$ & $3,9 \pm 1,8$ & $0,0^{*}$ & $1,8 \pm 1,7$ & $4,0 \pm 1,8$ & $0,0^{*}$ & $1,2 \pm 1,5$ & $2,5 \pm 1,7$ & $0,0^{*}$ & $0,3 \pm 0,7$ & $0,7 \pm 0,9$ & $0,00^{*}$ \\
\hline
\end{tabular}

*- diferença estatisticamente significante entre o lado irradiado e não irradiado $(p<0,05)$

Para comparação do nível de dor experimentada do lado irradiado com o lado não irradiado, fez-se o teste de Wilcoxon para os três meses avaliados cujos resultados estão demonstrados nos gráficos de $1 \mathrm{~A}$ a $1 \mathrm{C}$.

Para verificação da diferença da dor experimentada entre os tempos, utilizouse o teste não paramétrico de Friedman, conforme representado nos gráficos $1 \mathrm{~A}, 1 \mathrm{~B}$ e 1 .

Para demonstrar os resultados do teste de Friedman, foram utilizadas letras minúsculas, onde letras iguais significam não haver diferenças entre os tempos e letras diferentes significam haver diferenças entre si. 


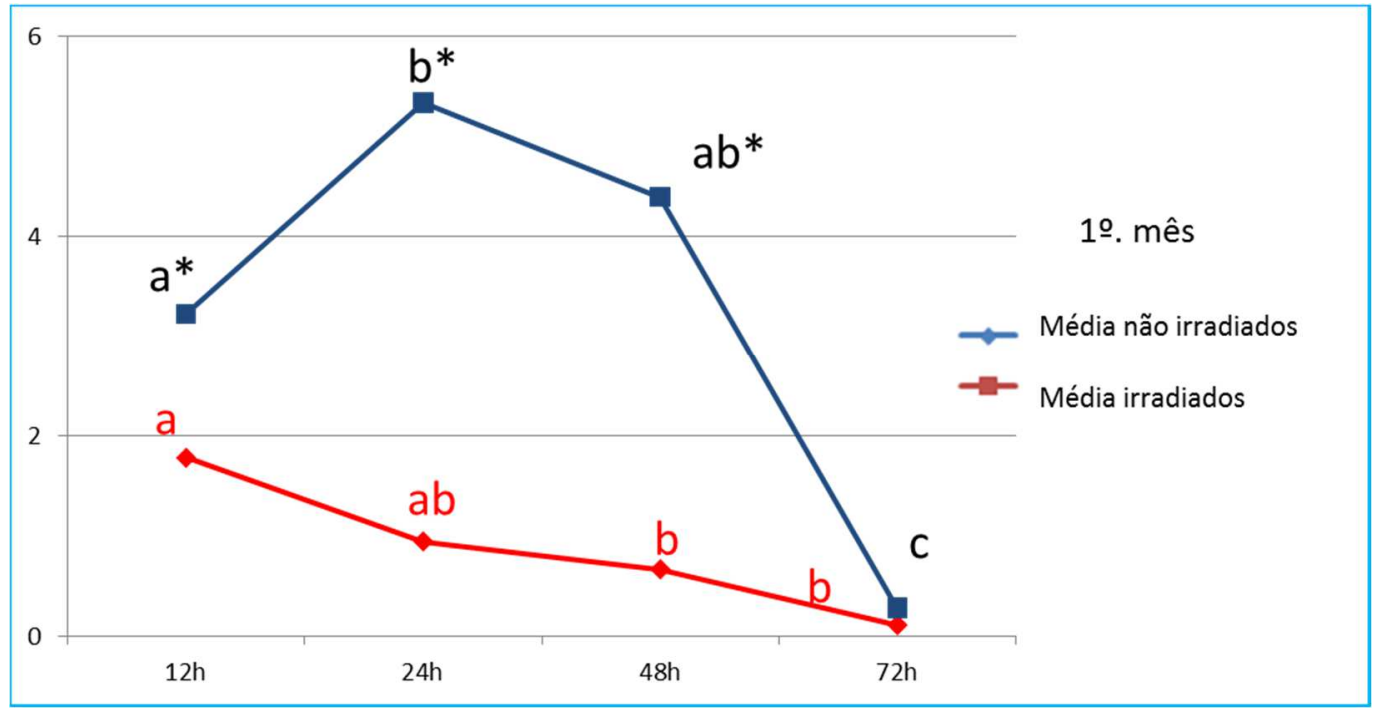

Gráfico 1A. Primeiro mês - Teste de Wilcoxon: Asterisco $\left({ }^{*}\right)$ significa diferença estatisticamente significante $(p<0,05)$, entre os dentes irradiados e os não irradiados. Teste de Friedman: tempos com letras iguais não possuem diferenças estatisticamente significantes entre si.

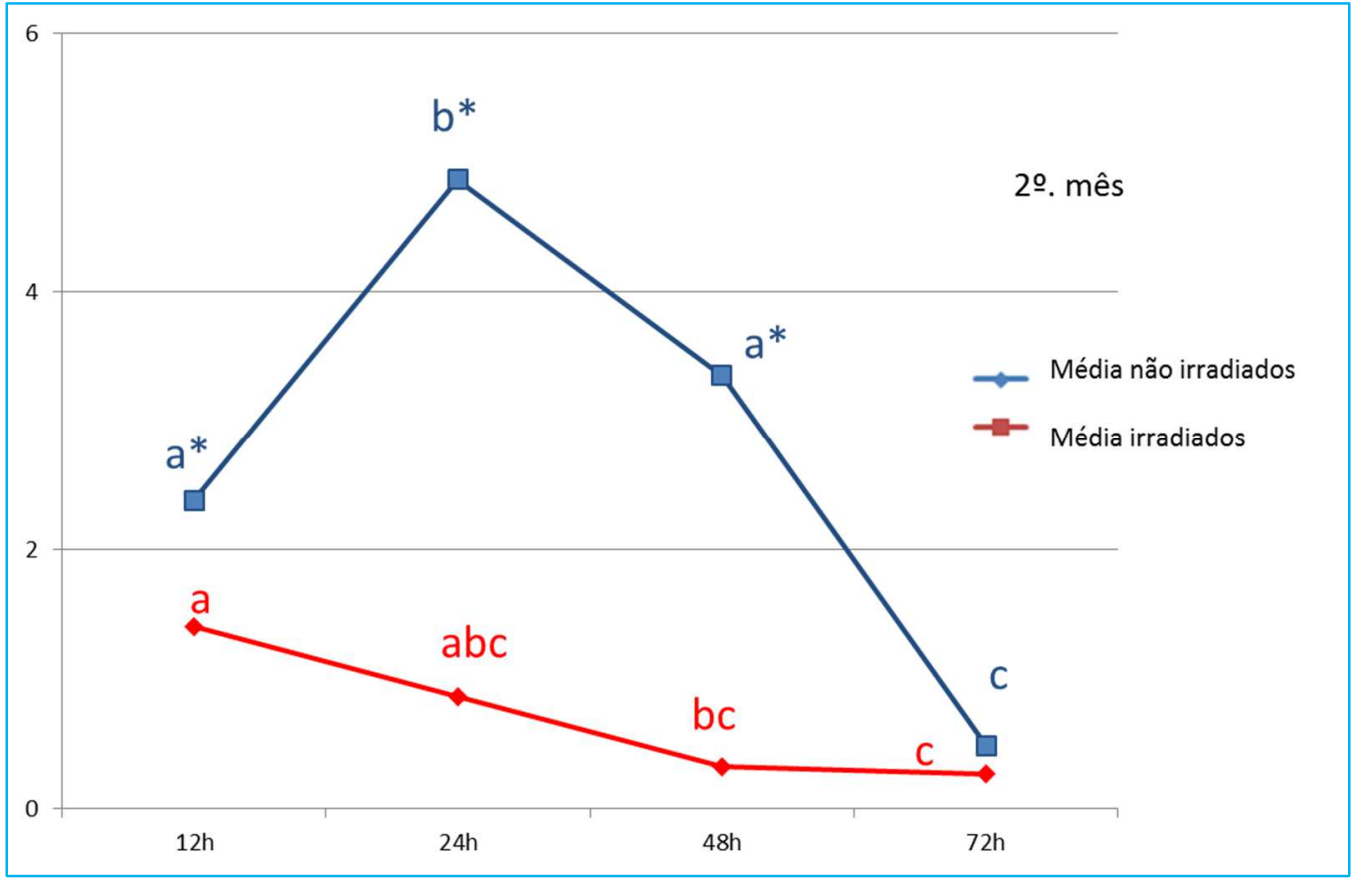

Gráfico 1B. Segundo mês - Teste de Wilcoxon: Asterisco $\left(^{*}\right)$ significa diferença estatisticamente significante $(p<0,05)$, entre os dentes irradiados e os não irradiados. Teste de Friedman: tempos com letras iguais não possuem diferenças estatisticamente significantes entre si. 


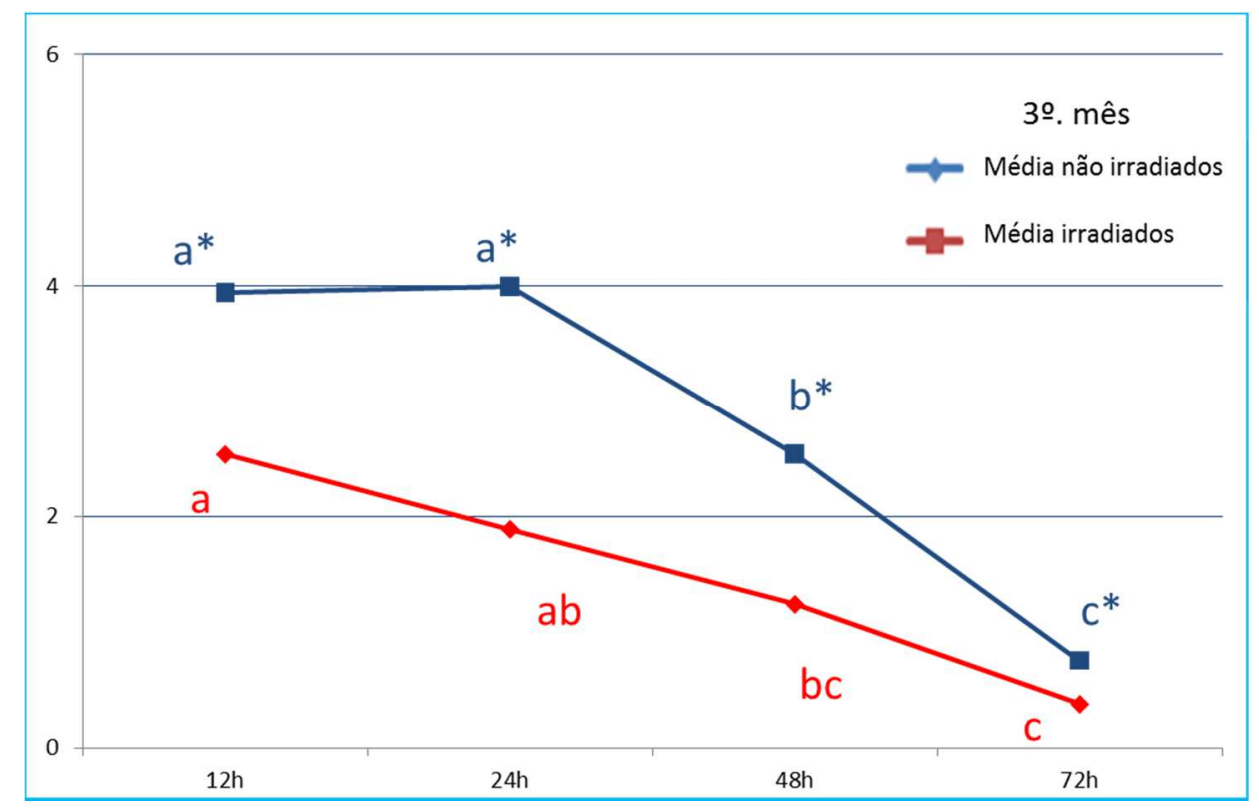

Gráfico 1C. Terceiro mês - Teste de Wilcoxon: Asterisco $\left(^{*}\right)$ significa diferença estatisticamente significante $(p<0,05)$, entre os dentes irradiados e os não irradiados. Teste de Friedman: tempos com letras iguais não possuem diferenças estatisticamente significantes entre si.

Observe que para os três meses avaliados houve uma diferença estatística significativa nos seguintes tempos: $12 \mathrm{~h}, 24 \mathrm{~h}$ e $48 \mathrm{~h}$ comparando-se o LI com o LNI (graf. 1A e 1B), exceto para o terceiro mês que apresentou diferenças estatisticamente significantes em que todos os tempos avaliados (graf. 1C), constatando o efeito do laser em baixa intensidade na inibição da dor.

A tabela 6 sintetiza o percentual de redução da dor nos tempos e períodos avaliados que apresentaram diferenças estatisticamente significantes. 
Tabela 6 - Percentual de redução da dor em todos os tempos avaliados que tiveram significância estatística. Destaques em vermelho.

\begin{tabular}{|c|c|c|c|c|c|}
\hline Períodos & Tempos & $\begin{array}{c}\text { Lado } \\
\text { Irradiado } \\
\text { (LI) }\end{array}$ & $\begin{array}{c}\text { Lado Não } \\
\text { Irradiado (LNI) }\end{array}$ & diferença & \% redução \\
\hline $1^{\circ}$ & $12 \mathrm{~h}$ & 1,78 & 3,22 & 1,44 & $44,72 \%$ \\
\hline \multirow[t]{2}{*}{ mês } & $24 \mathrm{~h}$ & 0,92 & 5,33 & 4,41 & $82,74 \%$ \\
\hline & $48 \mathrm{~h}$ & 0,67 & 4,39 & 3,72 & $84,74 \%$ \\
\hline 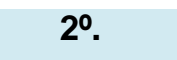 & $12 \mathrm{~h}$ & 1,41 & 2,38 & 0,97 & $40,76 \%$ \\
\hline \multirow[t]{2}{*}{ mês } & $24 \mathrm{~h}$ & 0,86 & 4,86 & 4 & $82,30 \%$ \\
\hline & $48 \mathrm{~h}$ & 0,32 & 3,35 & 3,03 & $90,45 \%$ \\
\hline 3‥ & $12 \mathrm{~h}$ & 2,54 & 3,95 & 1,41 & $35,70 \%$ \\
\hline \multirow[t]{3}{*}{ mês } & $24 \mathrm{~h}$ & 1,89 & 4 & 2,11 & $52,75 \%$ \\
\hline & $48 \mathrm{~h}$ & 1,24 & 2,54 & 1,3 & $51,18 \%$ \\
\hline & $72 \mathrm{~h}$ & 0,38 & 0,76 & 0,38 & $50,00 \%$ \\
\hline
\end{tabular}

Verificou-se na tabela 6 que o maior percentual de redução da dor inibida pela aplicação de laser se deu entre os tempos: $24 \mathrm{~h}$ e $48 \mathrm{~h}$.

Observou-se que no primeiro mês, no grupo de dentes não irradiados, a dor experimentada foi maior nos tempos de 24 e 48 horas (graf. 1A), no segundo mês, no tempo de 24h (graf. 1B) e no terceiro mês, nos tempos de 12 e 24 horas (grafico. 1C).

Já no grupo de dentes irradiados, a maior dor experimentada em todos os períodos, foi no tempo de $12 \mathrm{~h}$, diminuindo nos tempos de 24 e $48 \mathrm{~h}$, sendo praticamente inexpressivas no tempo de $72 \mathrm{~h}$, exceto no terceiro mês como demonstrado no gráfico $1 \mathrm{C}$. Houve uma diminuição decrescente da dor no decorrer dos tempos avaliados. 


\subsection{Análise da perda de ancoragem dos molares avaliado nos modelos de estudo sob a influência do laser}

Como a amostra foi composta por 21 pacientes totalizando 37 arcos dentários, ou seja, 16 pacientes pareados (arco superior e inferior) e 5 pacientes que foram utilizados somente o arco superior, houve a preocupação de saber se havia diferenças na movimentação dentária com a influência do laser, comparando-se os arcos superiores com os inferiores. Para esta verificação, foi empregada a análise da variância (ANOVA) a dois critérios de medidas repetidas como teste preliminar. Os fatores de estudo foram: a aplicação ou não de laser e o arco dentário (superior ou inferior).

Para isso foram excluídos cinco pacientes que somente os arcos superiores foram incluídos na amostra, pois a análise da variância é um tipo de teste que exige que todos os fatores estejam presentes em todos os indivíduos.

ANOVA a dois critérios mostrou não haver diferenças entre os arcos: $p=0,35$ *

A partir desta constatação, os cinco pacientes excluídos, foram reinseridos na amostra e para as análises seguintes foi adotado o valor de $\mathrm{N}=37$ arcos dentários.

Fez-se então, a análise da variância a um critério de medidas repetidas, cujo fator de estudo é a aplicação ou não de laser.

Os resultados desta análise mostraram haver diferenças no fator de estudo "laser" (irradiado e não irradiado): $p=0,000012$, no fator "tempo" (medidas repetidas): $p=0,000523$ e haver interação entre os fatores tempo $X$ laser: $p=$ 0,009778 .

A tabela 7 descreve as médias e desvios padrão nos três períodos de movimentação dentária dos molares avaliados e, por meio do teste de Tukey, descreve onde estão estas diferenças, ou seja, a quantidade de movimentação mesial dos molares avaliados (perda de ancoragem), comparando-se os lados irradiados e não irradiados. 
Tabela 7 -Quantidade de movimentação dos molares em $\mathrm{mm}$ medido em modelos nos períodos de tempo avaliados, para o grupo irradiado e não irradiado - Teste de Tukey.

\begin{tabular}{|c|c|c|c|c|c|}
\hline \multirow{2}{*}{ Variação } & \multicolumn{2}{|c|}{ Irradiado } & \multicolumn{2}{|c|}{ Não irradiado } & \multirow[b]{2}{*}{$p$} \\
\hline & $\begin{array}{c}\text { Média } \\
(\mathrm{mm})\end{array}$ & $\begin{array}{c}\mathrm{dP} \\
(\mathrm{mm})\end{array}$ & $\begin{array}{l}\text { Média } \\
(\mathrm{mm})\end{array}$ & $\begin{array}{c}\mathrm{dP} \\
(\mathrm{mm})\end{array}$ & \\
\hline $\mathrm{T} 2-\mathrm{T} 1$ & 0,54 & 0,36 & 0,97 & 0,42 & $0,000022^{*}$ \\
\hline T3-T2 & 0,58 & 0,36 & 0,73 & 0,33 & 0,51 \\
\hline T4-T3 & 0,47 & 0,31 & 0,58 & 0,32 & 0,77 \\
\hline
\end{tabular}

*- diferença estatisticamente significante entre o lado irradiado e não irradiado $(p<0,05)$

A tabela 8 mostra a média e o desvio padrão das diferenças da DPM entre os tempos inicial (T1) e final (T4) para o lado irradiado e não irradiado, ou seja, a quantidade de movimentação total dos molares para mesial (perda de ancoragem) no período total analisado (quatro meses).

Tabela 8 -Quantidade de movimentação dos molares em mm, medido em modelos nos períodos de tempo avaliados, para o grupo irradiado e não irradiado - Teste t pareado.

\begin{tabular}{ccccccccc}
\hline \multirow{2}{*}{ Variação } & \multicolumn{2}{c}{ Irradiado } & & \multicolumn{2}{c}{ Não irradiado } & Diferença & $t$ & $\mathrm{p}$ \\
\cline { 2 - 3 } & $\begin{array}{c}\text { Média } \\
(\mathrm{mm})\end{array}$ & $\begin{array}{c}\mathrm{Dp} \\
(\mathrm{mm})\end{array}$ & & $\begin{array}{c}\text { Média } \\
(\mathrm{mm})\end{array}$ & $\begin{array}{c}\mathrm{Dp} \\
(\mathrm{mm})\end{array}$ & & $0,000^{*}$ \\
\hline T4-T1 & 1,60 & 0,63 & & 2,29 & 0,61 & $-0,68$ & $-9,05$ & \\
\hline *- diferença estatisticamente significante entre o lado irradiado e não irradiado $(\mathrm{p}<0,05)$ &
\end{tabular}

Verificou-se que, em todos os períodos avaliados, houve uma diferença entre o grupo irradiado e o não irradiado, com uma menor movimentação do molar irradiado em relação ao seu contralateral não irradiado, porém, só houve diferença estatisticamente significante para o primeiro período avaliado (gráfico 2). 


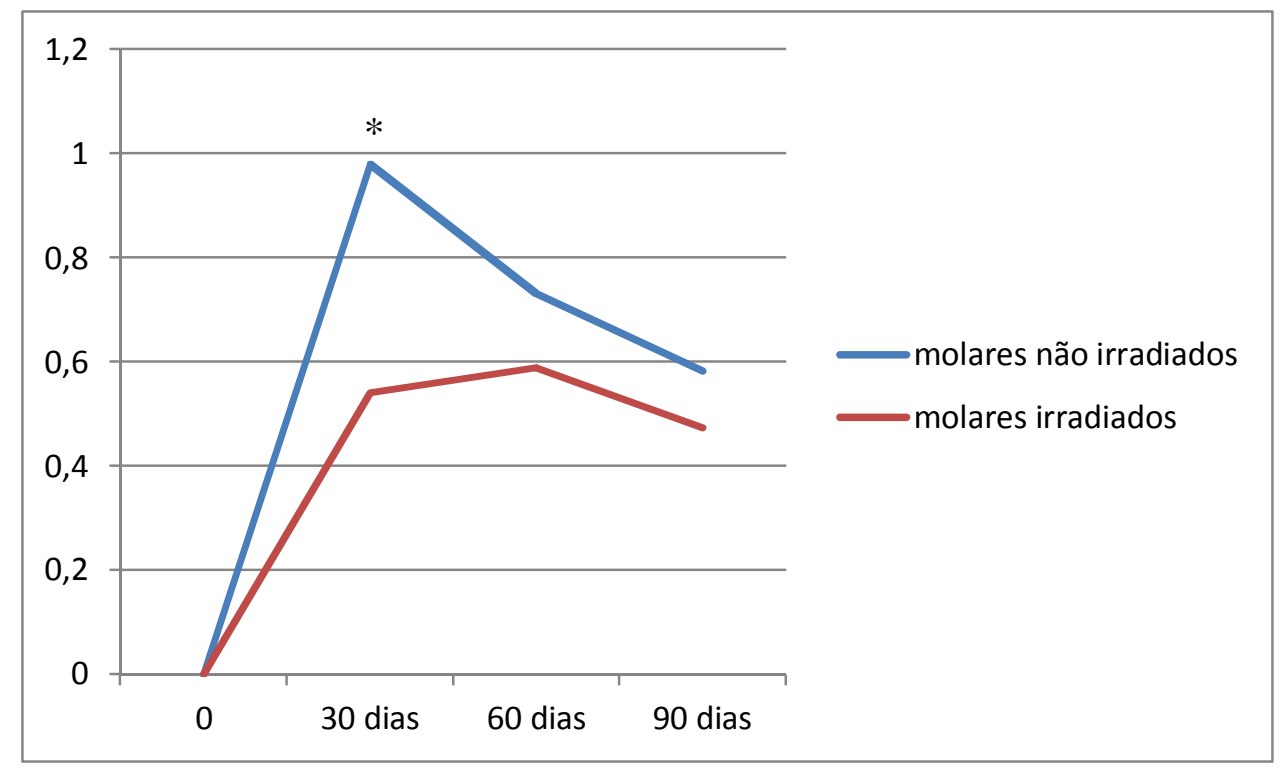

Gráfico 2 - Comparação da quantidade de movimentação dos molares irradiados em relação aos não irradiados $(\mathrm{mm})$ medido em modelos, nos períodos de tempo avaliados.

* diferença estatisticamente significante $(p<0,05)$

\subsection{Análise das tomografias computadorizadas cone beam}

\subsubsection{Análise da perda de ancoragem dos molares sob a influência do} laser

Para análise das tomografias, na avaliação da perda de ancoragem dos molares irradiados comparados com o seu contralateral, utilizou-se dois conjuntos de medidas de 37 arcos dentários, obtidas pelo programa Radiocef Studio 2, conforme descrito no capítulo "Material e Métodos".

Para esta análise, da mesma forma que ocorreu com a análise dos modelos, houve a preocupação de saber se havia diferenças na movimentação dentária sob a influência do laser, comparando-se os arcos superiores com os inferiores. Para esta verificação, foi empregada a análise da variância (ANOVA) a dois critérios de medidas repetidas. Os fatores de estudo foram: a aplicação ou não de laser e o arco dentário (superior ou inferior).

Foram então excluídos cinco pacientes que somente os arcos superiores foram incluídos na amostra. ANOVA a dois critérios mostrou não haver diferenças entre os arcos: $p=0,10^{*}$ 
A partir desta constatação, os cinco pacientes excluídos, foram reinseridos na amostra e adotado o valor de $\mathrm{N}=37$ arcos dentários.

A seguir foi aplicado o teste $t$ pareado para comparação da perda de ancoragem comparando-se os molares irradiados com os molares não irradiados.

A tabela 9 mostra a média e o desvio padrão das diferenças entre as tomografias do tempo inicial (T0) e final (T4) para o lado irradiado e não irradiado, ou seja, a quantidade de movimentação total dos molares para mesial (perda de ancoragem) no período total analisado (quatro meses).

Tabela 9 - Quantidade média de movimentação dos molares em $\mathrm{mm}$, medido em tomografias, comparando-se o tempo inicial com o final, para o grupo irradiado e não irradiado - Teste t pareado.

\begin{tabular}{l|cc|cc|c|c}
\hline Variação & \multicolumn{2}{|c|}{ Irradiado } & \multicolumn{2}{|c|}{ Não Irradiado } & diferença & P \\
\hline & $\begin{array}{c}\text { Média } \\
(\mathrm{mm})\end{array}$ & $\begin{array}{c}\mathrm{dP} \\
(\mathrm{mm})\end{array}$ & $\begin{array}{c}\text { Média } \\
(\mathrm{mm})\end{array}$ & $\begin{array}{c}\mathrm{dP} \\
(\mathrm{mm})\end{array}$ & & \\
\hline \multirow{2}{*}{ T4-T0 } & 1,17 & 0,87 & 1,95 & 0,83 & $-0,68$ & $0,000^{*}$ \\
\hline
\end{tabular}

*- diferença estatisticamente significante entre o lado irradiado e não irradiado $(p<0,05)$

Verificou-se que os molares irradiados (MI) perderam em média 1,17mm de ancoragem, enquanto que os molares não irradiados (MNI) perderam em média $1,95 \mathrm{~mm}$ de ancoragem, havendo uma diferença estatisticamente significante entre os dois grupos $(p=0,000)$.

Portanto, para o período analisado, houve uma menor movimentação do molar irradiado em relação ao seu contralateral não irradiado, conforme demonstrado no gráfico 3. 


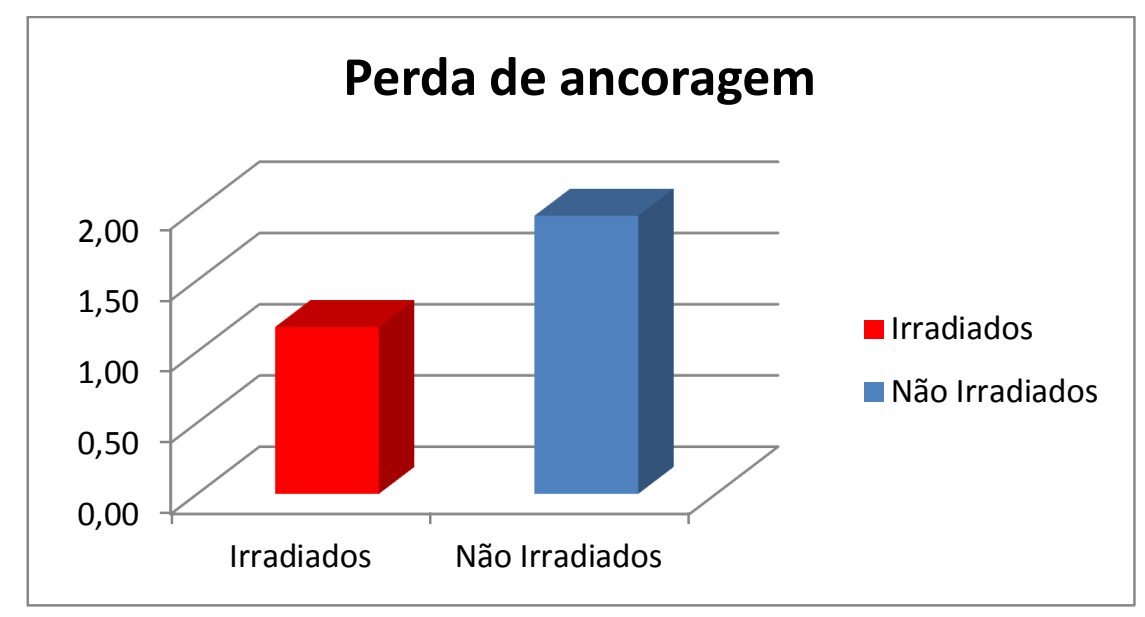

Gráfico 3 - Média em $\mathrm{mm}$ da perda de ancoragem em tomografias comparando-se o grupo de molares irradiados com os molares não irradiados.

\subsubsection{Análise das alterações promovidas pela retração inicial dos}

\section{caninos sob a influência do laser}

Para complementação deste estudo verificou-se também as alterações de angulação nos caninos e molares dos lados irradiado (LI) e não irradiado (LNI), bem como a quantidade linear de retração inicial dos caninos comparando-se ambos os lados cujos dados encontram-se na tabela 10. 
Tabela 10 - Alterações médias promovidas pela retração inicial dos caninos - arco dentário superior e inferior - teste " $\mathrm{t}$ " pareado. $\mathrm{Ml}=$ Molar Irradiado; $\mathrm{MNI}=$ Molar Não irradiado; $\mathrm{LI}=$ Lado Irradiado; $\mathrm{LNI}=$ Lado Não irradiado.

\begin{tabular}{|c|c|c|c|c|c|c|c|c|}
\hline Arco & \multirow[t]{2}{*}{ Variável } & \multicolumn{2}{|c|}{ TO } & \multicolumn{2}{|c|}{ T4 } & \multicolumn{2}{|c|}{ Diferença } & $p$ \\
\hline \multirow{7}{*}{ 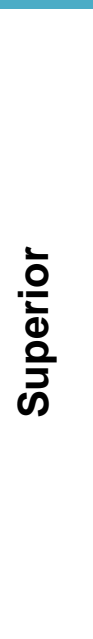 } & & Média & dP & Média & dP & Média & dP & \multirow{3}{*}{$0,37 n s$} \\
\hline & $\begin{array}{l}\text { Ang. Molar } \\
\text { Irradiado (MI) }\end{array}$ & 87,18 & 6,37 & 92,34 & 6,56 & 5,16 & 4,48 & \\
\hline & $\begin{array}{l}\text { Ang. Molar Não } \\
\text { Irr. (MNI) }\end{array}$ & 87,28 & 4,89 & 91,43 & 6,64 & 4,15 & 2,98 & \\
\hline & Ang. Can. LI & 110,26 & 5,33 & 99,77 & 6,21 & $-10,49$ & 4,84 & $026 \mathrm{~ns}$ \\
\hline & Ang.Can. LNI & 110,05 & 6,53 & 100,36 & 5,48 & $-9,69$ & 3,75 & \\
\hline & $\begin{array}{l}\text { Retr. Can. LI } \\
(\mathrm{mm})\end{array}$ & 48,88 & 3,95 & 45,96 & 4,53 & $-2,92$ & 1,64 & \\
\hline & $\begin{array}{l}\text { Retr.Can. LNI } \\
(\mathrm{mm})\end{array}$ & 50,06 & 3,99 & 47,04 & 4,21 & $-3,02$ & 1,15 & , Jons \\
\hline & $\begin{array}{l}\text { Ang.Molar } \\
\text { Irradiado (MI) }\end{array}$ & 81,17 & 4,70 & 84,24 & 4,36 & 3,07 & 2,51 & $024 n s$ \\
\hline 흐 & $\begin{array}{l}\text { Ang. Molar } \\
\text { Não Irr. (MNI) }\end{array}$ & 79,29 & 3,81 & 84,07 & 5,24 & 4,78 & 4,24 & \\
\hline$\underset{\square}{ \pm}$ & Ang. Can. LI & 92,06 & 5,90 & 84,74 & 6,83 & $-7,32$ & 5,06 & 05 \\
\hline & Ang.Can. LNI & 93,99 & 5,58 & 82,57 & 6,30 & $-11,42$ & 5,17 & \\
\hline & $\begin{array}{l}\text { Retr. Can. LI } \\
(\mathrm{mm})\end{array}$ & 3,77 & 3,40 & 0,96 & 4,03 & $-2,81$ & 2,21 & \\
\hline & $\begin{array}{l}\text { Retr. Can.LNI } \\
(\mathrm{mm})\end{array}$ & 3,36 & 4,04 & 1,24 & 4,20 & $-2,12$ & 1,83 & $0,0 / \mathrm{ns}$ \\
\hline
\end{tabular}

ns - diferença estatisticamente não significante

Observou-se que tanto os molares superiores irradiados como os não irradiados angularam suas coroas para mesial numa média de 4 a 5,16 graus não havendo diferenças estatisticamente significantes entre $\circ \mathrm{MI}$ e $\circ \mathrm{MNI}(\mathrm{p}=0,37)$. $\mathrm{O}$ mesmo ocorreu com os molares inferiores numa média de 3,07 a 4,78 graus e valor de $p=0,24$.

Em relação à angulação das coroas dos caninos superiores comparando-se o LI com o LNI, houve uma angulação para distal numa média de 9,7 a 10,49 graus, porém não havendo diferenças estatisticamente significantes $(p=0,26)$. $O$ mesmo ocorreu com os caninos inferiores numa média de 7,33 a 11,42 graus e valor de $\mathrm{p}=0,05$. 
Em relação à retração dos caninos superiores, comparando-se o $\mathrm{LI}$ com o LNI, houve uma retração de 2,93 a 3,52mm em média, não havendo diferenças estatisticamente significantes $(p=0,24)$ entre os dois lados. O mesmo ocorreu com os caninos inferiores numa média de retração de 0,61 a 2,77mm e valor de $p=0,05$.

\subsubsection{Análise da reabsorção radicular e da crista óssea alveolar sob a influência do laser}

A tabela 11 sintetiza a reabsorção radicular para os dentes avaliados comparando-se o lado irradiado com o não irradiado.

Tabela 11 - Reabsorção radicular medida a distância do ápice radicular até cúspide/incisal em $\mathrm{mm}$ (T4-T0), comparando-se o lado irradiado com o lado não irradiado. Teste "t" pareado.

\begin{tabular}{|c|c|c|c|c|c|c|}
\hline \multicolumn{7}{|c|}{ REABSORÇÃO RADICULAR: IRRADIADO x NÃO IRRADIADO } \\
\hline & dente & raiz & $\begin{array}{l}\text { Média / dP } \\
\text { Irradiado } \\
\quad(\mathrm{mm})\end{array}$ & $\begin{array}{c}\text { Média / } \\
\text { dP } \\
\text { não } \\
\text { irradiado } \\
(\mathrm{mm})\end{array}$ & diferença & $\mathrm{p}$ \\
\hline \multirow[t]{5}{*}{ arco superior } & \multirow[t]{3}{*}{ primeiro molar } & RMV & $0,20 \pm 0,23$ & $0,34 \pm 0,28$ & $-0,14$ & $0,15 \mathrm{~ns}$ \\
\hline & & RDV & $0,23 \pm 0,28$ & $0,37 \pm 0,24$ & $-0,13$ & $0,13 n s$ \\
\hline & & $\mathrm{RP}$ & $0,19 \pm 0,19$ & $0,34 \pm 0,26$ & $-0,15$ & $0,06 n s$ \\
\hline & segundo pré-molar & RV & $0,17 \pm 0,18$ & $0,26 \pm 0,21$ & $-0,1$ & $0,09 \mathrm{~ns}$ \\
\hline & canino & $\mathrm{R}$ & $0,19 \pm 0,26$ & $0,29 \pm 0,29$ & $-0,1$ & $0,29 \mathrm{~ns}$ \\
\hline \multirow[t]{4}{*}{ arco inferior } & \multirow[t]{2}{*}{ primeiro molar } & RMV & $0,31 \pm 0,31$ & $0,53 \pm 0,33$ & $-0,22$ & $0,06 n s$ \\
\hline & & $\mathrm{RD}$ & $0,18 \pm 0,18$ & $1,14 \pm 2,49$ & $-0,97$ & $0,14 \mathrm{~ns}$ \\
\hline & segundo pré-molar & $\mathrm{R}$ & $0,22 \pm 0,24$ & $0,38 \pm 0,28$ & $-0,16$ & $0,13 n s$ \\
\hline & canino & $\mathrm{R}$ & $0,25 \pm 0,21$ & $0,47 \pm 0,33$ & $-0,22$ & $0,06 n s$ \\
\hline
\end{tabular}

RMV: raiz mésio-vestibular, RDV: raiz disto-vestibular, RP: raiz palatina, RV: raiz vestibular, RD: raiz distal e R: raiz única.

Observa-se que não houve diferenças estatisticamente significantes tanto para o arco superior como para o inferior em relação à reabsorção radicular.

Os resultados obtidos para a avaliação da crista óssea alveolar estão demonstrados na tabela 12. 
Tabela 12 - Diferença da altura da crista óssea alveolar medida a distância CA-JCE em mm (T4-T0), comparando-se o lado irradiado com o lado não irradiado, tanto para o arco superior como para 0 inferior. Teste "t" pareado.

\begin{tabular}{|c|c|c|c|c|c|c|c|c|c|}
\hline \multicolumn{6}{|c|}{ arco superior } & \multicolumn{4}{|c|}{ arco inferior } \\
\hline dente & raiz & $\begin{array}{l}\text { Média / } \\
\text { dP } \\
\text { Irradiado } \\
\text { (mm) }\end{array}$ & $\begin{array}{l}\text { Média / } \\
\text { dP } \\
\text { não } \\
\text { irradiado } \\
\text { (mm) }\end{array}$ & dif. & $p$ & $\begin{array}{l}\text { Média / } \\
\text { dP } \\
\text { Irradiado } \\
\text { (mm) }\end{array}$ & $\begin{array}{c}\text { Média / } \\
\text { dP } \\
\text { não } \\
\text { irradiado } \\
(\mathrm{mm})\end{array}$ & dif. & $p$ \\
\hline \multirow{4}{*}{$\begin{array}{l}\text { primeiro } \\
\text { molar }\end{array}$} & M & $0,06 \pm 0,08$ & $0,09 \pm 0,07$ & $-0,03$ & 0,19 & $0,08 \pm 0,08$ & $0,13 \pm 0,10$ & $-0,05$ & 0,2 \\
\hline & D & $-0,02 \pm 0,08$ & $0,09 \pm 0,10$ & $-0,11$ & $0,00^{*}$ & $0,09 \pm 0,07$ & $0,15 \pm 0,13$ & $-0,06$ & 0,06 \\
\hline & V & $0,09 \pm 0,08$ & $0,20 \pm 0,16$ & $-0,11$ & $0,01^{*}$ & $0,09 \pm 0,14$ & $0,18 \pm 0,15$ & $-0,08$ & 0,16 \\
\hline & L & $0,09 \pm 0,08$ & $0,12 \pm 0,09$ & $-0,04$ & 0,21 & $0,04 \pm 0,09$ & $0,11 \pm 0,11$ & $-0,07$ & 0,09 \\
\hline \multirow{4}{*}{$\begin{array}{l}\text { segundo } \\
\text { pré- } \\
\text { molar }\end{array}$} & M & $0,12 \pm 0,11$ & $0,15 \pm 0,12$ & $-0,02$ & 0,54 & $0,11 \pm 0,11$ & $0,12 \pm 0,10$ & $-0,01$ & 0,84 \\
\hline & $\mathrm{D}$ & $0,10 \pm 0,12$ & $0,11 \pm 0,10$ & $-0,02$ & 0,51 & $0,11 \pm 0,12$ & $0,12 \pm 0,13$ & $-0,01$ & 0,78 \\
\hline & V & $0,07 \pm 0,08$ & $0,12 \pm 0,12$ & $-0,05$ & 0,16 & $0,04 \pm 0,10$ & $0,18 \pm 0,37$ & $-0,14$ & 0,16 \\
\hline & $\mathrm{L}$ & $0,10 \pm 0,13$ & $0,13 \pm 0,14$ & $-0,03$ & 0,39 & $0,11 \pm 0,09$ & $0,11 \pm 0,10$ & 0 & 1 \\
\hline \multirow[t]{2}{*}{ canino } & V & $0,12 \pm 0,12$ & $0,20 \pm 0,16$ & $-0,08$ & 0,12 & $0,08 \pm 0,09$ & $0,13 \pm 0,10$ & $-0,04$ & 0,23 \\
\hline & L & $0,10 \pm 0,11$ & $0,17 \pm 0,12$ & $-0,07$ & 0,06 & $0,11 \pm 0,14$ & $0,16 \pm 0,14$ & $-0,04$ & 0,2 \\
\hline
\end{tabular}

*- diferença estatisticamente significante entre o lado irradiado e não irradiado $(p<0,05)$

M: mesial, D: distal, V: vestibular, D: distal

Os resultados da tabela 12 demonstram que não houve diferença da altura da crista óssea alveolar para os dentes avaliados com a influência da laserterapia, exceto para o primeiro molar superior em que houve uma menor perda da crista óssea alveolar estatisticamente significante na região distal e vestibular do lado irradiado com um ligeiro aumento da crista óssea alveolar na região distal. 
Discussão

"Temos o destino que merecemos. O nosso destino está de acordo com os nossos méritos."

Albert Einstein 



\section{DISCUSSÃO}

Para um melhor entendimento, a discussão divide-se nos seguintes tópicos: seleção da amostra e metodologia adotada; efeitos do laser em baixa intensidade na analgesia, efeitos do laser em baixa intensidade na ancoragem; avaliação da integridade óssea e por último, considerações clínicas e propostas para estudos futuros.

\subsection{Seleção da amostra e metodologia adotada}

Este estudo teve caráter prospectivo, de forma que os pacientes foram selecionados previamente, assim como o tratamento ortodôntico foi realizado sempre da mesma maneira, seguindo os mesmos critérios e o laser foi aplicado sempre por um único operador. Este cuidado se fez necessário para haver uma maior padronização em relação à calibração do operador, que poderia influenciar na quantidade de energia depositada no tecido alvo. Por exemplo, se houvesse inclinação do "spot size" do aparelho e este não ficasse perpendicular e em contato com a mucosa, ou a superfície não estivesse limpa e seca, haveria uma perda da energia, ou seja, uma maior reflexão da luz laser, e isto poderia refletir-se na intensidade da foto resposta, e portando, nos resultados obtidos (LIZARELLI, 2007)

\section{Seleção da amostra}

A amostra estudada foi composta por pacientes jovens (idade mínima de 13 anos e máxima de 17; média de 14,4 anos). Encontra-se na literatura, que a foto resposta também depende do nível da atividade metabólica dos tecidos (ALMEIDALOPES, 2004; LIZARELLI, 2007), sendo desta forma, essencial que os pacientes da amostra estivessem numa mesma fase do metabolismo corpóreo. Em pacientes adultos, na fase em que a atividade metabólica está mais reduzida, quando utilizada a laserterapia, ocorrerá uma resposta mais intensa em relação a pacientes mais jovens, que já estão com o metabolismo mais acelerado (LIZARELLI, 2007).

Ainda tivemos o cuidado, por meio da anamnese, de verificar se na amostra selecionada havia algum caso de doença sistêmica ou uso de medicamentos que 
pudessem influenciar no metabolismo celular, pelos mesmos motivos acima relacionados, ou seja, interferência direta no metabolismo celular, atenuando ou exacerbando os efeitos do laser (YAMASAKI et al., 1984; KOBAYASHI, Y., et al., 1998) , gerando uma falsa resposta celular. Por estes motivos, foram selecionados somente os pacientes que não estavam utilizando nenhum tipo de medicamento ou que não apresentassem qualquer tipo de doença sistêmica.

O cálculo do tamanho amostral foi feito com base no estudo de Cruz et al. (2004) que indicou uma amostra mínima de 12 pacientes, adotando-se um erro alfa de $5 \%$, um erro Beta de $20 \%$ e considerando o desvio-padrão do referido trabalho $(0,27 \mathrm{~mm})$ com uma diferença esperada entre as médias de 0,5mm. Contudo, prevendo possíveis perdas de pacientes durante a etapa experimental, adotou-se para este trabalho, uma amostra de 21 indivíduos.

Por se tratar de um ensaio clínico em que o próprio paciente foi seu próprio controle, pois de um lado do arco dentário se aplicou laser e do outro não, a quantidade de variáveis era bem restrita na comparação dos hemiarcos entre si, portanto, a análise de 21 pacientes, num total de 37 arcos dentários, apresentou-se suficiente para que pudéssemos realizar este estudo, ou seja, um maior número comparado aos trabalhos de Cruz et al. (2004), Limpanichkul et al. (2006), Genc et al (2012) e Doshi-Mehta e Bhad-Patil (2012) que utilizaram amostras variando de 11 (valor mínimo) a 20 indivíduos (valor máximo), com as seguintes quantidades de arcos dentários: 11, 12, 20 e 30 respectivamente.

Devido à dificuldade de se obter uma amostra que necessitasse de exodontias de pré-molares e ao mesmo tempo pudéssemos perder um pouco de ancoragem sem comprometimento dos resultados finais, foram selecionados pacientes com má oclusão de classe I de Angle com biprotrusões e/ou apinhamentos não tão severos, porém o suficiente para indicação de extração dentária, cujos arcos superiores e inferiores foram incluídos na amostra e pacientes com má oclusão de classe II de Angle, com indicação para exodontias de prémolares superiores, onde somente os arcos dentários superiores foram inseridos na amostra. Vale salientar que não houve influência do tipo de má oclusão, já que o objetivo principal deste estudo foi avaliar os efeitos do LBI na movimentação dos molares durante o período de retração inicial de caninos.

Todos os pacientes selecionados deveriam apresentar a condição de retração da bateria anterior com possibilidade de alguma perda de ancoragem, pois para 
avaliar os efeitos do LBI na ancoragem ortodôntica, os molares deveriam estar completamente livres para movimentação, ou seja, sem nenhum dispositivo para ancoragem mecânica.

Apesar da literatura informar que quando a ancoragem máxima é solicitada, a perda de ancoragem é maior em paciente classe I de Angle $(\mathbf{0 , 6} \mathbf{m m})$ do que em paciente classe II (0,28mm) (HART; TAFT; GREENBERG, 1992), esta variável foi controlada, pois a amostra selecionada não precisava de ancoragem máxima e a menor distância inter-bráquetes (maior apinhamento) que poderia solicitar mais do sistema de ancoragem em pacientes classe I foi compensada pela seleção da amostra com apinhamentos não tão severos que propiciavam uma maior distância entre os caninos em retração e os segundos pré-molares e consequentemente menor força transmitida ao sistema de ancoragem, como também, após a extração, uma distância razoável entre eles, de modo que até o final do experimento (90 dias) não houvesse contato entre a distal do canino e a mesial do segundo pré-molar. Em apenas um paciente isto ocorreu, sendo o mesmo eliminado da amostra. Além disso, a maioria dos pacientes eram classe I de Angle $(n=16)$, sendo apenas 5 pacientes classe II.

Outro fator que poderia interferir na ancoragem seriam os contatos oclusais no sentido ântero-posterior aumentando a resistência ao deslocamento dentário, porém, o platô oclusal em resina nos segundos molares inferiores, descrita no capítulo "material e métodos", eliminou qualquer contato dentário ou intercuspidação mais pronunciada em alguns pacientes (classe I ou classe II) que promoveriam uma menor perda de ancoragem.

\section{Técnica ortodôntica adotada}

Em relação ao tratamento ortodôntico realizado, adotamos a técnica do arco segmentado, de acordo com os trabalhos de Sousa et al. (2011) e Orlando et al (2010), onde todos os pacientes foram tratados da mesma forma, ou seja, com o mesmo tipo de bráquete, uso de fio segmentado redondo 0.16 " de NiTi e mola de $\mathrm{NiTi}$, liberando uma força de $150 \mathrm{~g}$. Acreditamos que o uso do arco segmentado proporciona um controle melhor do sistema de ancoragem comparado ao arco contínuo utilizado por outros autores (CRUZ et al., 2004; LIMPANICHKUL et al., 2006; DOSHI-MEHTA; BHAD-PATIL, 2012; GENC, et al., 2012) de forma que um lado não interferisse no contralateral utilizado como controle. Dependendo do grau 
de apinhamento, inclinação ou tamanho das raízes dos incisivos, por exemplo, poderia haver uma maior ou menor solicitação do sistema de ancoragem como descrito por Geron et al. (2003). Além disso, a nossa intenção era verificar o efeito do LBI em relação à ancoragem no início da movimentação ortodôntica sem nenhuma interferência, onde acontecem os eventos celulares e moleculares sem influências de mediadores já existentes por movimentos ortodônticos prévios. Já o fio segmentado 0,16 de NiTi proporciona uma movimentação ideal, sem excesso de força para os caninos que estavam, na maioria dos casos, em infravestibuloversão.

\section{Força adotada}

Para uma melhor padronização da força liberada, utilizamos as molas de NiTi, ao invés do elástico em corrente. Isto ocorreu pois com as molas, temos um melhor controle da força liberada (força contínua), enquanto que os elastômeros sofrem uma influência maior do meio bucal, como por exemplo, a temperatura, deteriorando-se e perdendo-se mais facilmente o controle da força aplicada nos caninos (força intermitente), fato corroborado por Cruz et al. (2004), Limpanichkul et al. (2006), Sousa et al. (2011), Genc et al. (2012) e Doshi-Mehta e Bhad-Pathil (2012), além das molas de NiTi oferecerem uma melhor padronização da força exercida nos molares que serviram de ancoragem.

Como as molas eram reativadas mês a mês para $150 \mathrm{~g} /$ força calibrada com um dinamômetro, não havia tempo hábil para que perdessem totalmente a força. Este fato era observado no retorno dos pacientes com as molas ainda distendidas, garantindo desta forma uma força mais próxima da constante.

Segundo Ren, Maltha e Kuijpers-Jagtman (2003), clinicamente a relação entre a magnitude de força ortodôntica e a quantidade de movimento dentário durante o tratamento ortodôntico ativo é considerada um método prático na identificação da força ideal para cada indivíduo. Desta forma, devemos iniciar o movimento com uma força relativamente baixa e observamos clinicamente o comportamento da movimentação dentária associado à sintomatologia dolorosa e assim, decidiremos se vale a pena aumentar a força aplicada ou não, até certo limite. Porém isto é válido apenas clinicamente, pois quando temos que optar por uma força tal que, com certeza, movimentará determinado dente ou grupo de dentes, como no caso de pesquisas clínicas, temos que partir de algum parâmetro de força já consagrado na literatura. 
Respaldados na literatura, adotamos o nível de força de $150 \mathrm{~g}$ para retração inicial de caninos, sugerido por Smith e Burstone (1984) como força mínima ideal, e sugerido por Mao, Wang e Kopher (2003), como força máxima ideal para a movimentação ortodôntica. Além disso, nos estudos de Limpanichkul et al. (2006), Cruz et al. (2004), Sousa et al. (2011), Youssef et al. (2008) Doshi-Mehta e BhadPatil (2012), foi utilizada esta mesma força.

Com relação à metodologia adotada para a avaliação da integridade tecidual, a tomografia computadorizada do feixe cônico (TCFC) foi o método de escolha. Para a mensuração da perda de ancoragem dos molares, adotamos tanto os modelos de estudo como as tomografias computadorizadas do feixe cônico.

\section{TCFC - justificativa}

As inclusões das tomografias foram essenciais como recurso de análise dos tecidos periodontais envolvidos, visto que as radiografias, por gerarem a imagem num único plano, sobrepõem estruturas anatômicas que poderiam mascarar alguma alteração. Como uma das proposições deste trabalho foi a verificação da integridade tecidual após o emprego do uso do laser, então as tomografias seriam os exames mais adequados para esta análise, por não gerarem nenhuma dúvida, visto que as imagens geradas são tridimensionais e em vários planos, podendo-se, portanto, avaliar com supremacia a qualidade dos tecidos periodontias após a movimentação e aplicação do laser. Com a inclusão das tomografias, foi desnecessária a realização das radiografias ortodônticas convencionais (telerradiografias e panorâmica) e das radiografias periapicais dos dentes envolvidos na retração inicial dos caninos, expondo o menos possível os pacientes às radiações.

Conforme tabela abaixo, extraída de um artigo recente de Scholz (2011), o autor discute as vantagens e desvantagens do uso da tomografia cone beam. Uma das pouquíssimas desvantagens relatadas, além de ser oneroso, seria a radiação sofrida pelo paciente, porém para este estudo, se somarmos as doses de radiação geradas pelas radiografias: panorâmica, telerradiografia e periapicais dos dentes envolvidos, necessárias para avaliação da integridade tecidual, ou seja, molares superiores e inferiores direito e esquerdo, pré-molares superiores e inferiores direito e esquerdo e caninos superiores e inferiores direito e esquerdo (12 incidências = 145 $\mu \mathrm{Sv})$, a dose seria de aproximadamente $163 \mu \mathrm{Sv}$, enquanto que com a tomografia cone bem, esta dose foi em torno de $135 \mu \mathrm{Sv}$, ou seja, inferior. 


\begin{tabular}{|c|c|c|}
\hline Exames Odontológicos & $\begin{array}{c}\text { Dose de } \\
\text { radiação } \\
\text { efetiva } \\
\mu^{*} \mathbf{S v}^{\star}\end{array}$ & $\begin{array}{l}\text { Radiação natural } \\
\text { equivalente a: }\end{array}$ \\
\hline Panorâmica & $3-11$ & Meio a um dia \\
\hline Telerradiografia lateral & $5-7$ & Meio a um dia \\
\hline Radiografia oclusal & 5 & Meio dia \\
\hline Radiografia interproximal & $1-4$ & Meio dia \\
\hline Radiografias periapicais (boca completa) & $30-170$ & $4-21 d$ \\
\hline ATM (série) & $20-30$ & $3-4 d$ \\
\hline Tomografia Computadorizada do Feixe Cônico (TCFC) & $40-135$ & $4-17 d$ \\
\hline \multicolumn{3}{|l|}{ Exames Médicos } \\
\hline Raio X (tórax) & 100 & $10-12 d$ \\
\hline Mamografia & 700 & $88 \mathrm{~d}$ \\
\hline Tomografia Computadorizada convencional (TC) & 8000 & $1000 \mathrm{~d}$ \\
\hline
\end{tabular}

Interpretação da dose relativa/TCFC = tomografia computadorizada cone

OBS: Para efeito de cálculo, adotamos a dose máxima descrita na tabela acima. Para o cálculo da dose das radiografias periapicais que seriam utilizadas neste estudo, selecionou-se a dose de radiação máxima referente à boca toda (170 $\mu \mathrm{Sv}$ ), dividiu-se pelo número de incidências da boca completa (14 incidências), obtendo-se desta forma, a dose referente à uma incidência (12,14 $\mu \mathrm{Sv})$. Multiplicouse então este valor pelo número de periapicais necessárias para este estudo (12 x $12,14 \mu \mathrm{Sv})$, dando, portanto, um total de $144,71 \mu \mathrm{Sv}$, que somadas às radiações das radiografias: panorâmica e telerradiografia, daria um total de 163,71 $\mu$ Sv.

Mesmo que eliminássemos as radiografias: panorâmica e telerradiografia do conjunto de radiografias necessárias para avaliação da integridade tecidual, ainda assim, a dose promovida pela TCFC seria menor, ou seja, $135 \mu$ Sv comparado à $144,71 \mu \mathrm{S} v$ proporcionado pelas radiografias periapicais.

\section{Metodologia utilizada na avaliação da ancoragem: TCFC}

Uma das grandes vantagens da TCFC para avaliação da movimentação ortodôntica dos molares que serviram de ancoragem em relação aos modelos de estudo se deve ao fato de ser possível selecionar pontos anatômicos fixos imutáveis com a mecânica ortodôntica tanto na maxila, como na base do crânio e na mandíbula. Além disso, pudemos avaliar outras variáveis difíceis de serem avaliadas nos modelos de estudo, como por exemplo, as angulações dentárias.

Para as análises cefalométricas, utilizamos neste estudo cefalogramas obtidos de um tomógrafo iCAT, utilizando o programa Dolphin, cujas projeções foram 
adquiridas no modo ortogonal e cuja referência foi o plano sagital mediano, obtendose desta forma duas telerradiografias laterais: direita e esquerda. Tivemos o cuidado de obter as telerradiografias desta forma, pois respaldados na literatura, há uma maior precisão em comparação com as radiografias cefalométricas convencionais (KUMAR et al., 2007; LUDLOW et al., 2009). Além disso, pontos de difícil identificação devido às sobreposições nos cefalogramas convencionais foram utilizados para este estudo, como por exemplo: Gônio, Orbitário e pontos dentários e de acordo com Ludlow et al. (2009) para a identificação destes pontos, a TCFC confere uma melhor precisão.

No presente estudo para avaliação da movimentação dos molares e retração dos caninos sob a influência do laser, selecionamos como pontos cefalométricos, além da ponta de cúspide dos molares (mésio-vestibular) e caninos, as seguintes referências: plano de Frankfurt e plano pterigoideo vertical (PTV/perpPoOr) para os molares superiores e plano mandibular e linha MperpGoMe para os inferiores.

A escolha destas referências se deu primeiramente devido á sua localização, ou seja, para os molares superiores procuramos referências localizadas próximas à maxila (terço médio da face) e para os molares inferiores, referências na mandíbula. A sua localização foi bastante importante, pois se escolhêssemos, por exemplo, uma referência no terço médio da face para a mandíbula, caso houvesse um mínimo deslocamento ântero-posterior desta no momento da aquisição da imagem tomográfica, o valor medido para a movimentação dos dentes inferiores não seriam confiáveis.

Outro fator a ser considerado na escolha destas referências foi a sua confiabilidade, ou seja, a escolha de estruturas anatômicas que não sofreriam interferências do tratamento ortodôntico durante o período avaliado. Sendo assim, a fossa pterigopalatina, a órbita, o meato acústico externo e a parte posterior da sínfise mandibular foram as estruturas de escolha por estarem dentro desta condição, além de representarem pontos de fácil identificação e visualização na tomografia cone beam.

Estes pontos anatômicos, linhas e planos de referências foram então enviados para a empresa Radiomemory (Belo Horizonte) que desenvolveu a análise cefalométrica intitulada 3D e inserida no programa Radiocef, conforme a figura 11. A escolha deste software se deu pelo fato de não haver dispositivos suficientes no Dolphin para realização destas medidas, nem tão pouco há permissão para 
introdução de novos pontos cefalométricos ou novas medidas lineares e angulares, enquanto que na empresa Radiomemory há um departamento científico disponível para estudo e desenvolvimento de ferramentas que auxiliam em pesquisas.

Para validação desta análise foram efetuados todos os testes necessários pelo departamento científico desta empresa, bem como a aluna responsável (MVSS) fez o traçado manual de pelo menos doze telerradiografias (6 pares - direita e esquerda) comparando com os resultados obtidos diretamente pela análise 3D com os obtidos manualmente. Caso houvesse diferenças estatisticamente significantes, o departamento científico era comunicado sobre qual era a variável discrepante e novos ajustes eram feitos no programa até o ponto de não haver mais diferenças, validando assim a análise 3D.

Para avaliar o erro intraexaminador das medidas analisadas neste estudo foram remedidas 13 tomografias. Observou-se que não houve erro sistemático e 0 erro casual foi irrelevante para as variáveis analisadas (tabelas 3 e 4) o que indica a precisão e reprodutibilidade das medidas analisadas. Esta ausência de erros foi devido à definição e precisão na visualização dos pontos cefalométricos sem a sobreposição de estruturas anatômicas obtidas por meio das tomografias cone beam.

\section{Metodologia utilizada na avaliação da ancoragem: modelos de estudo}

Uma das grandes vantagens dos modelos de estudo em relação às TCFC é a possibilidade de mensuração em várias etapas do experimento.

Utilizamos como um dos pontos de referência, a porção mais cervical da papila entre os incisivos centrais inferiores/superiores como no trabalho de Sousa et al. (2011). Esta referência foi a mesma para o arco superior e inferior e pelo fato da mecânica ter sido feita com arco segmentado, esta região sofreu pouca influência, e se caso houvesse alguma influência, como por exemplo, uma melhora no apinhamento ou alteração na inclinação dos incisivos, isso refletiria em uma alteração muito suave na região cervical. Além disso, como já mencionado, foi utilizado o mesmo ponto de referência para os molares de ambos os lados, portanto, qualquer modificação na papila entre os incisivos, seria também repercutido em ambos os lados.

Por este ser um trabalho pioneiro na literatura que avaliou a influência do LBI na ancoragem ortodôntica em humanos, tivemos que eleger um ponto de referência 
dentário mais apropriado, pois os demais trabalhos existentes na literatura avaliaram a influência do LBI na estimulação da velocidade da movimentação dentária em caninos (CRUZ et al., 2004; LIMPANICHKUL et al., 2006; YOUSSEF et al., 2008; DOSHI-MEHTA; BHAD-PATIL, 2012) ou incisivos laterais (GENC et al., 2012). A fossa central dos primeiros molares ao invés de uma das cúspides, como nos demais trabalhos (CRUZ et al., 2004; LIMPANICHKUL et al., 2006; YOUSSEF et al., 2008; SOUSA et al., 2011; DOSHI-MEHTA; BHAD-PATIL, 2012) foi a referência dentária de escolha para este estudo em modelos, pois as possíveis giroversões causadas pela mesialização dos molares poderiam dar margem a resultados duvidosos, caso elegêssemos uma das cúspides. Portanto, a fossa central dos primeiros molares foi a referência dentária mais adequada.

Uma das influências que este ponto de referência possivelmente sofreria, seria uma maior ou menor angulação dos molares que serviram de ancoragem que poderia acusar em um falso resultado, ou seja, se o LBI proporcionasse uma maior angulação, a distância da fossa central até a papila (DPM) seria menor do lado irradiado, comparado ao lado controle (quanto maior a angulação, menor a distância DPM).

Esta variável foi eliminada com o estudo nas tomografias computadorizadas do feixe cônico (TCFC) que comprovaram não haver diferenças estatisticamente significantes em relação à angulação quando comparados os molares irradiados com os molares não irradiados, conforme tabela 10.

Tivemos ainda o cuidado de avaliar as restaurações de todos os primeiros molares no intuito de verificar se havia uma escultura adequada para identificação da fossa central. Caso isto ocorresse, antes do início do experimento, a restauração era refeita dentro dos padrões anatômicos adequados.

Outras referências mencionadas na literatura não poderiam ser utilizadas neste estudo, como por exemplo, as rugosidades palatinas (LIMPANICHKUL et al., 2006) e mini-implantes (GENC et al., 2012). A primeira não seria possível, pois utilizamos arcos dentários superiores e inferiores, e a segunda referência seria inviável, pois não poderíamos estudar os efeitos do LBI nos molares, caso utilizássemos os mini-implantes para distalização dos caninos.

Pelo fato de já ser consagrado na literatura como padrão "gold standard" na mensuração em modelos (STEVENS et al., 2006), o paquímetro digital foi o 
instrumento escolhido para mensuração nos modelos de estudo, conforme descrito no capítulo "material e métodos" e adotado por alguns autores que utilizaram metodologia semelhante (YOUSSEF et al., 2008; DOSHI-MEHTA; BHAD-PATIL, 2012; GENC et al., 2012). Outros métodos mais recentes, como o modelo digital associado a um software (SOUSA et al., 2011), trazem inúmeras vantagens em relação ao armazenamento de imagens e sua ampliação facilitando a mensuração, porém a maioria dos trabalhos publicados demonstra não haver diferenças em relação aos resultados obtidos quando comparados com os modelos convencionais mensurados com paquímetros digitais (SANTORO et al., 2003; ZILBERMAN; HUGGARE; PARIKAKIS, 2003; QUIMBY et al., 2004; STEVENS et al., 2006; SOUSA et al., 2012).

Descartamos o método da medição por meio de um paquímetro digital "in loco", como no trabalho de Cruz et al. (2004) por haver inúmeras desvantagens, como por exemplo:

a) ausência de precisão das mensurações, por ser mais difícil medir diretamente na cavidade bucal;

b) impossibilidade da realização do erro do método, por não ser possível remedir a mesma fase num outro momento;

c) perda de dados, pois como não há a existência de modelos, não é possível eventuais checagens ou conferências.

Para avaliar o erro intraexaminador das medidas analisadas em modelos foram remedidos 28 modelos de estudo. Observou-se que não houve erro sistemático e o erro casual foi irrelevante nas variáveis analisadas (tabela 2) o que indica a precisão e reprodutibilidade na sua mensuração, proporcionada pelo paquímetro digital. 


\section{Metodologia utilizada na avaliação da integridade tecidual em} tomografias: método da navegação axial guiada.

O método da navegação axial guiada é um método que permite determinar o comprimento linear máximo de cada raiz dentária tendo como pontos de referência o ápice radicular e a ponta de cúspide correspondente à raiz dentária. O movimento do cursor no plano axial permite identificar os pontos de referência nos planos sagital e coronal e por isso este método foi denominado de navegação axial guiada (CASTRO et al., 2012).

A grande vantagem deste método é identificar o melhor corte que represente o comprimento real do dente e compará-lo em dois tempos distintos sendo que a diferença entre os tempos representa a quantidade de reabsorção radicular.

Linge e Linge (1991) descreveram um método para determinar o comprimento radicular em que as medidas foram efetuadas em radiografias periapicais antes e após o tratamento ortodôntico. Os pontos de referência foram a junção cementoesmalte e o ápice radicular e a correção de magnificação foi baseada na proporção do comprimento da coroa dentária obtida nas radiografias antes e após o tratamento ortodôntico. Neste método as medições da reabsorção radicular tornam-se muito complexas devido a algumas limitações inerentes à técnica radiográfica, como por exemplo, mudanças do comprimento do dente, dificuldade de localização da junção cemento-esmalte e as variações nas incidências de raio- $X$.

Em nosso estudo, utilizando o método da navegação axial guiada em tomografias, estes fatores limitantes foram atenuados ou praticamente inexistentes pelo fato das medidas efetuadas nas imagens geradas serem absolutamente semelhantes em comparação com as medidas realizadas diretamente no objeto de estudo como comprovado por diversos trabalhos existentes na literatura ( KOBAYASHI et al., 2004; LASCALA, PANELLA E MARQUES, 2004; SUOMALAINEN et al., 2008; PATCAS et al., 2012). Além disso, a TCFC permite uma correta visualização da junção cemento-esmalte e da porção superior da crista óssea alveolar (PATCAS et al., 2012).

Os mesmos cortes selecionados para a avaliação da reabsorção radicular foram utilizados para verificação da crista óssea alveolar comparando-se os dois tempos: inicial e final da retração de caninos. Os pontos de referência utilizados 
foram a junção cemento-esmalte (JCE) e o ápice da crista óssea alveolar (CA) paralelo ao longo eixo do dente.

Uma das grandes vantagens das TCFC para avaliação da perda da crista óssea alveolar em relação às imagens radiográficas convencionais é a possibilidade de mensuração nos lados vestibular e lingual. Além disso, as tomografias fornecem informações sobre a perda óssea da crista alveolar que não poderiam ser detectadas pelas radiografias convencionais como confirmado por Lund, Grondahl, K. e Grondahl, H-G. (2012).

\subsection{Efeitos do LBI na analgesia}

A capacidade de fototerapia para promover o alívio da dor é dose-dependente (LAAKSO et al., 1994).

$\mathrm{Na}$ literatura, não há dúvidas de que praticamente todos os pacientes submetidos ao tratamento ortodôntico fixo sofrem algum tipo de desconforto, seja na separação dos dentes para posterior bandagem, ou na inserção do arco, chegando a níveis de dor que podem até desencorajá-los à continuidade do tratamento ou até mesmo ao seu início (POLAT; KARAMAN, 2005; KRISHNAN, 2007; ANGELIERI et al., 2011).

A percepção da dor varia consideravelmente de paciente para paciente. Assim, a dor é uma sensação altamente subjetiva e devido a isto, há uma grande dificuldade na sua quantificação em pesquisas científicas (NGAN; KESS; WILSON, 1989; LIM; LEW; TAY, 1995; TURHANI et al., 2006; ANGELIERI et al., 2011).

A escala visual análoga foi proposta por Huskisson (1974), para quantificar a dor que compreende uma linha (normalmente de $10 \mathrm{~cm}$ ), com uma escala de 0 a 10 , representando os limites da dor experimentada, sendo que "0" representa ausência de dor e o 10, dor intensa. Para sua utilização, os pacientes são orientados a marcarem na linha, o ponto correspondente à intensidade da dor por eles experimentada.

A escala visual analógica (VAS- Visual Analogue Scale), embora seja um método subjetivo, tem sido empregada por vários autores (LIM; LEW; TAY, 1995; TURHANI et al., 2006; TORTAMANO et al., 2009; ANGELIERI et al., 2011; ARTÉS- 
RIBAS; ARNABAT-DOMINGUEZ; PUIGDOLLERS, 2012), por ser um método confiável, seguro e de fácil entendimento (PRICE et al., 1983).

A escala visual analógica foi adotada para quantificação da dor no presente estudo. Para facilitar a mensuração da sensibilidade dolorosa, utilizamos a escala visual analógica simplificada com recurso visual como no estudo de Angelieri et al. (2011), conforme anexos 5 e 6.

Os pacientes foram orientados a marcarem a dor quantificada 12, 24, 48 e 72 horas após a ativação ortodôntica, tanto do lado direito como do lado esquerdo, e para que a subjetividade não influenciasse nos resultados; no lado contralateral (placebo) foi simulada a aplicação do laser.

Normalmente, a dor durante 0 tratamento ortodôntico apresenta-se perceptível principalmente nos primeiros três dias, tendo seu ponto máximo em 24 horas, e decrescendo após o terceiro dia pós-ativação (NGAN; KESS; WILSON, 1989; TURHANI et al., 2006). Estes dados corroboram com o presente estudo, onde se observou-se uma média maior de dor nos tempos de 12 a 48 horas pós-ativação, decrescendo consideravelmente decorridas 72 horas (terceiro dia) da ativação ortodôntica.

Já é unânime entre os pesquisadores e clínicos que se utilizam desse recurso no dia-a-dia, que a laserterapia inibe a dor total ou parcialmente (NGAN; KESS; WILSON, 1989; LIM; LEW; TAY, 1995; GUTKNECHT; FRANZEN, 2004; TURHANI et al., 2006; GENOVESE, 2007; LIZARELLI, 2007; YOUSSEF et al., 2008; TORTAMANO et al., 2009; ANGELIERI et al., 2011; ARTÉS-RIBAS; ARNABATDOMINGUEZ; PUIGDOLLERS, 2012; BICAKCI et al., 2012), contudo, os protocolos de aplicação ainda geram controvérsias, pois na literatura são encontradas diferentes dosimetrias para o mesmo procedimento.

Se observarmos o quadro 2 simplificado abaixo e ordenado de forma crescente em relação à energia por ponto, ao contrário do que ocorre na estimulação da movimentação ortodôntica, protocolos de energias mais altas são recomendados. Assim, nota-se no quadro 2, que quando apenas um dente é irradiado, a energia recomendado por pontos varia no intervalo de $\mathbf{1} \mathbf{J}-\mathbf{2} \mathbf{J}$ e a densidade de energia varia entre $5 \mathrm{~J} / \mathrm{cm} 2$ a $8 \mathrm{~J} / \mathrm{cm} 2$. Quando todos os dentes da arcada dentária são irradiados, os intervalos recomendados de energia variam de 0,5 $\mathbf{J}$ - 2,25 $\mathbf{J}$ por ponto e os intervalos de densidade de energia variam de 4,25 $\mathrm{J} / \mathrm{cm} 2-16 \mathrm{~J} / \mathrm{cm} 2$. 
Quadro 2: Dosimetrias utilizadas pelos autores na intenção de analgesia pós-ativação ortodôntica

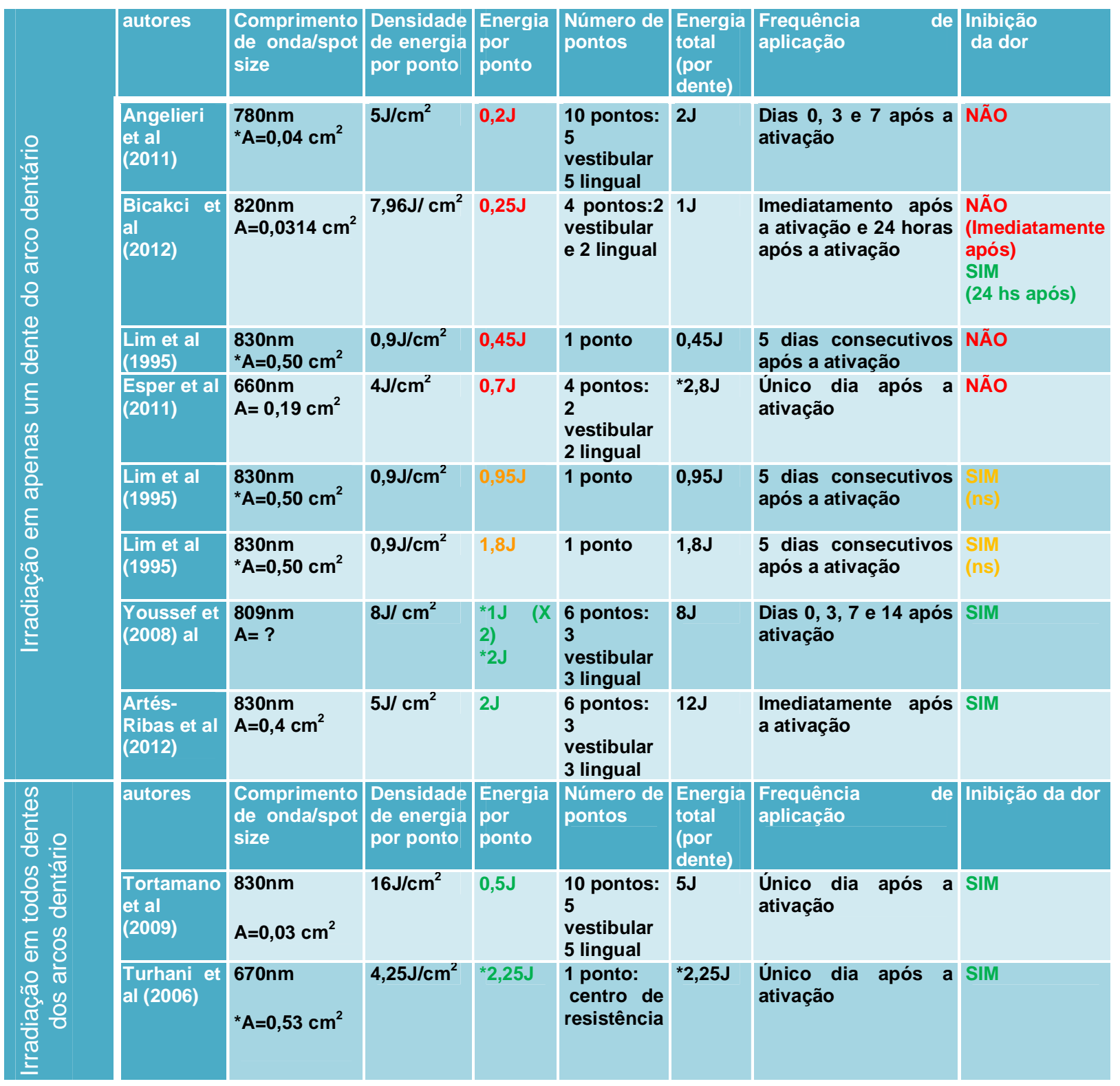

*dados calculados pela aluna com base nas informações impressas no artigo

ns- valores médios maiores para inibição da dor, porém sem diferenças estatisticamente significantes (tendência de inibição da dor)

Provavelmente, os efeitos positivos com analgesia obtida quando todo o arco dentário é irradiado com baixas doses de energia por ponto, como demonstrado por Tortamano et al (TORTAMANO et al., 2009) deveram-se à somatização dos efeitos da irradiação de toda a inervação do arco dentário e das células do ligamento periodontal.

No presente estudo, foi utilizada uma energia de 4,2J por ponto, 42J por dente, com uma densidade de energia de $105 \mathrm{~J} / \mathrm{cm} 2$, ou seja, uma dose maior do 
que os autores descritos no quadro 2 utilizaram e obtivemos uma inibição da dor em todos os períodos avaliados e nos seguintes tempos: 12, 24 e 48 horas, exceto para o terceiro mês que obtivemos uma inibição de dor em todos os tempos avaliados (12, 24, 48 e 72h).

O maior percentual de redução da dor se deu nos tempos de 24 e 48 horas. Estes resultados corroboram com Lim et al. (1995) e Turhani et al. (2006) que encontraram níveis de dor mais baixas nos segundos e terceiros dias (LIM; LEW; TAY, 1995) ou até 30 horas em média após a ativação (TURHANI et al., 2006).

Talvez estes resultados estejam associados à quantidade de prostaglandinas presentes no ligamento periodontal, além da inibição de outros fatores, pois se sabe que as prostaglandinas atingem seu pico máximo no ligamento periodontal entre 24 a 48 horas (GRIEVE et al., 1994; REN; VISSINK, 2008) e, justamente neste intervalo de tempo obtivemos os melhores percentuais em relação à inibição da dor, conforme tabela 6, corroborando com o ensaio clínico de Bicakci et al. (2012) que estudando o efeito do LBI na inibição da dor após a colocação das bandas nos primeiros molares por meio de uma escala visual analógica decorridos $5 \mathrm{~min}$, 1h e $24 \mathrm{~h}$ pósativação e avaliando também a presença de prostaglandinas (PGE2) no fluido gengival crevicular, comparando-se o lado irradiado com o lado não irradiado, observaram haver diferenças estatisticamente significantes após 24 horas da aplicação do laser, concluindo que o laser pode ser um excelente recurso para redução da dor pós-ativação ortodôntica.

$\mathrm{Na}$ tabela 5 observamos ainda que a inibição da dor promovida pela laserterapia foi menor, embora estatisticamente significante, no lado irradiado em todos os períodos no tempo avaliado de 12h. Respaldados na literatura, sabemos que a dor imediata e até aproximadamente $12 \mathrm{~h}$ após a ativação se dá principalmente pela liberação de histamina oriundas da degranulação de mastócitos deflagrando uma resposta inflamatória aguda com a migração de neutrófilos e macrófagos dos capilares sanguíneos (CONSOLARO, 2002; KRISHNAN; DAVIDOVITCH, 2006. O LBI por sua vez, estimula a degranulação dos mastócitos, aumentando a liberação de histamina (VASHEGHANI et al., 2008; PEREIRA et al., 2010; MONTEIRO et al., 2011), desta forma, a vasodilatação é promovida por período maior de tempo. Por conseguinte, a permeabilidade é aumentada, facilitando o aporte sanguíneo com células de defesa e nutrientes para 
a região afetada (VASHEGHANI et al., 2008; PEREIRA et al., 2010; MONTEIRO et al., 2011).

Talvez o estímulo da degranulação dos mastócitos e liberação de histamina causado pela laserterapia seja o motivo pelo qual em todos os períodos analisados no tempo de $12 \mathrm{~h}$ houve uma menor inibição da dor (tab. 2), embora estatisticamente significante) pelo LBI comparados aos tempos de 24 e 48h, já que a histamina é a responsável pela dor nas primeiras horas pós-ativação.

Claro que a movimentação ortodôntica, como relatada na revisão de literatura, é complexa envolvendo muitos fatores, portanto, mais estudos são necessários para elucidarmos os efeitos do LBI tanto na movimentação ortodôntica como na inibição da dor.

\subsection{Efeitos do LBI na ancoragem ortodôntica}

Antes de discutirmos os resultados encontrados para ancoragem, tanto em modelos de estudo como em tomografias, faz-se necessário abordarmos um tópico fundamental quando trabalhamos com laser em baixa intensidade: a dosimetria.

\section{Dosimetria}

Karu (KARU, 1990), com base em seus estudos experimentais em organismos unicelulares, já afirmava que os efeitos do LBI no tecido biológico são dose-dependente e comprimento de onda-dependente. Chamava também a atenção dos pesquisadores, observando-se que cada tipo de linhagem de célula poderia ter um efeito distinto, caso houvesse variação de comprimento de onda e da dose de energia recebida, passando da estimulação do metabolismo celular para a inibição.

Porém, quando se trata de movimentação ortodôntica, a complexidade aumenta consideravelmente, pois também aumenta o número de eventos celulares, moleculares e teciduais envolvidos, já descritos por inúmeros autores (DAVIDOVITCH et al., 1980; MOSTAFA; WEAKS-DYBVIG; OSDOBY, 1983; GRIEVE et al., 1994; LEE, et al., 2004; KRISHNAN; DAVIDOVITCH, 2006; CONSOLARO, 2012).

Respaldados na literatura, adotamos um comprimento de onda na faixa do infravermelho, que é o mais apropriado para que se possa atingir o tecido ósseo 
(WAN; ANDERSON; PARRISH, 1981; KOLA'ROVA'; DITRICHOVA'; WAGNER, 1999; GUTKNECHT; FRANZEN, 2004; LIZARELLI, 2007; SOUSA et al., 2011; STOLIK et al., 2011). Observe no quadro 1, transcrito parcialmente, que todos os autores utilizaram o comprimento de onda na faixa do infravermelho (CRUZ et al., 2004; LIMPANICHKUL et al., 2006; YOUSSEF, et al., 2008; CAMACHO; CUJAR, 2010; SOUSA et al., 2011; DOSHI-MEHTA; BHAD-PATIL, 2012; GENC, et al., 2012).

Quadro 1: Resumo das dosimetrias encontradas na literatura e seus efeitos em humanos para o estímulo da movimentação dentária induzida ortodonticamente.

\begin{tabular}{|c|c|c|c|c|c|c|c|c|c|}
\hline & autores & $\begin{array}{l}\text { Compri } \\
\text { mento de } \\
\text { onda/ } \\
\text { spot size }\end{array}$ & $\begin{array}{l}\text { Densidade } \\
\text { de energia } \\
\text { por ponto }\end{array}$ & $\begin{array}{l}\text { Ener } \\
\text { gia } \\
\text { por } \\
\text { pon } \\
\text { to }\end{array}$ & $\begin{array}{l}\text { Número } \\
\text { de } \\
\text { pontos } \\
\text { por dente }\end{array}$ & $\begin{array}{l}\text { Total } \\
\text { de } \\
\text { energia } \\
\text { por dia/ } \\
\text { dente }\end{array}$ & $\begin{array}{l}\text { Total de } \\
\text { energia } \\
\text { por mês }\end{array}$ & $\begin{array}{l}\text { Frequência } \\
\text { de aplicação }\end{array}$ & $\begin{array}{l}\text { Acelera } \\
\text { ção da } \\
\text { movi } \\
\text { men } \\
\text { tação }\end{array}$ \\
\hline \multirow{6}{*}{ 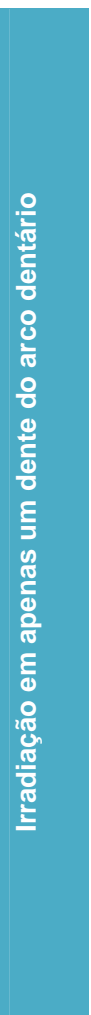 } & $\begin{array}{l}\text { Limpanichkul } \\
\text { et al } \\
(2006)\end{array}$ & $\begin{array}{l}860 \mathrm{~nm} / \\
0,09 \mathrm{~cm}^{2}\end{array}$ & $25 \mathrm{~J} / \mathrm{cm}^{2}$ & $2,3 \mathrm{~J}$ & $\begin{array}{l}8 \text { pontos: } \\
4 \\
\text { vestibular } \\
4 \text { lingual }\end{array}$ & $18,4 J^{*}$ & $55,2 J^{*}$ & $\begin{array}{l}3 \text { dias } \\
\text { consecutivos } \\
\text { após ativação }\end{array}$ & NÃO \\
\hline & $\begin{array}{l}\text { Youssef } \\
\text { et al } \\
(2008)\end{array}$ & $\begin{array}{l}809 \mathrm{~nm} \\
?\end{array}$ & $8 \mathrm{~J} / \mathrm{cm}^{2}$ & $\begin{array}{l}1 \mathrm{~J}(X \\
2)^{\star} \\
2 \mathrm{~J}^{\star}\end{array}$ & $\begin{array}{l}6 \text { pontos: } \\
3 \\
\text { vestibular } \\
3 \text { lingual }\end{array}$ & $8 \mathrm{~J}$ & 32J* & $\begin{array}{l}\text { Dias } 0,3,7 \text { e } \\
14 \\
\text { após cada } \\
\text { ativação }\end{array}$ & SIM \\
\hline & $\begin{array}{l}\text { Doshi-Mehta } \\
\text { e Bhad-Patil } \\
\text { (2012) }\end{array}$ & $\begin{array}{l}800 \mathrm{~nm} / \\
0,04 \mathrm{~cm}^{2}\end{array}$ & $5 \mathrm{~J} / \mathrm{cm}^{2}$ & $0,8 \mathrm{~J}^{*}$ & $\begin{array}{l}10 \\
\text { Pontos: } \\
5 \\
\text { vestibular } \\
5 \text { lingual }\end{array}$ & $8 \mathrm{~J}$ & $32 \mathrm{~J}$ & $\begin{array}{l}\text { Dias } 0,3,7 \text { e } \\
14 \\
\text { após ativação } \\
\text { no primeiro } \\
\text { mês e a cada } \\
15 \text { dias até a } \\
\text { completa } \\
\text { retração. }\end{array}$ & SIM \\
\hline & $\begin{array}{l}\text { Genc et al } \\
(2012)\end{array}$ & $\begin{array}{l}808 \mathrm{~nm} \\
0,28 \mathrm{~cm}^{2 \star}\end{array}$ & $0,71 \mathrm{~J} / \mathrm{cm}^{2}$ & $0,2 \mathbf{J}^{*}$ & $\begin{array}{l}10 \\
\text { Pontos: } \\
5 \\
\text { vestibular } \\
5 \text { lingual }\end{array}$ & $2 \mathbf{J}^{*}$ & $12 J^{*}$ & $\begin{array}{l}\text { Dias } 0,3,7, \\
14,21 \text { e } 28 \\
\text { após ativação }\end{array}$ & SIM \\
\hline & $\begin{array}{l}\text { Cruz et al } \\
(2004)\end{array}$ & $\begin{array}{l}780 \mathrm{~nm} / \\
0,04 \mathrm{~cm}^{2}\end{array}$ & $5 \mathrm{~J} / \mathrm{cm}^{2}$ & $0,2 \mathbf{J}^{*}$ & $\begin{array}{l}10 \\
\text { Pontos: } \\
5 \\
\text { vestibular } \\
5 \text { lingual }\end{array}$ & $2 J^{*}$ & $8 \mathbf{J}^{\star}$ & $\begin{array}{l}\text { Dias } 0,3,7 \text { e } \\
14 \\
\text { Após cada } \\
\text { ativação }\end{array}$ & SIM \\
\hline & $\begin{array}{l}\text { Sousa et al } \\
(2011)\end{array}$ & $\begin{array}{l}780 \mathrm{~nm} / \\
0,04 \mathrm{~cm}^{2}\end{array}$ & $5 \mathrm{~J} / \mathrm{cm}^{2}$ & $0,2 \mathrm{~J}$ & $\begin{array}{l}10 \\
\text { Pontos: } \\
5 \\
\text { vestibular } \\
5 \text { lingual }\end{array}$ & $2 J$ & 6J & $\begin{array}{l}\text { Dias } 0,3 \text { e } 7 \\
\text { após cada } \\
\text { ativação }\end{array}$ & SIM \\
\hline 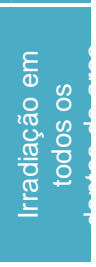 & $\begin{array}{l}\text { Camacho } \\
\text { et al } \\
(2010)\end{array}$ & $\begin{array}{l}830 \mathrm{~nm} \\
0,028 \mathrm{~cm}^{2 \star}\end{array}$ & $80 \mathrm{~J} / \mathrm{cm}^{2 * \star}$ & $2,2 J^{\star \star}$ & $\begin{array}{l}2 \text { pontos: } \\
1 \\
\text { vestibular } \\
1 \text { lingual }\end{array}$ & $\begin{array}{l}4,4 J \mathrm{~J} \\
12 \\
\text { Dentes } \\
\text { por } \\
\text { arco } \\
\text { (aproxi } \\
\text { mada } \\
\text { mente)* }\end{array}$ & $\begin{array}{l}52,8 J^{\star} \\
\text { por arco } \\
\text { (aproxi } \\
\text { mada } \\
\text { mente) }\end{array}$ & $\begin{array}{l}\text { Único dia } \\
\text { após ativação }\end{array}$ & SIM \\
\hline
\end{tabular}

**dados cedidos pelos autores por e-mail cujas correções constam no anexo 1 *dados calculados pela aluna com base nas informações impressas no artigo 
Como a densidade de energia depende da ponta ativa do aparelho de laser (spot size) (EDUARDO et al., 2004; LIZARELLI, 2007) e os autores utilizaram aparelhos diferentes, então a energia por ponto foi considerada para efeito de comparação entre os trabalhos selecionados na revisão sistemática da literatura e o quadro 1 foi ordenado em ordem crescente em relação à energia por ponto.

Note que nos resultados deste quadro, todos os autores obtiveram os mesmos resultados, ou seja, houve um maior estímulo de movimentação ortodôntica com a aplicação do LBI, exceto no estudo de Limpanichkul et al. (2006) que com a energia por ponto maior em relação aos outros autores, obtiveram um efeito nulo em relação ao estímulo da movimentação ortodôntica. Estes dados confirmam os estudos anteriores, que afirmam que LBI é dose-dependente (KARU, 1990; SAITO; SHIMIZU, 1997; COOMBE et al., 2001; GENOVESE, 2007; LIZARELLI, 2007; MARQUEZAN; BOLOGNESE; ARAÚJO, 2010; SOUSA et al., 2010; ANGELIERI et al., 2011).

Observamos também que quando desejamos movimentar ortodonticamente apenas um dente, como no caso de retração inicial de caninos, densidades de energia entre 0,71 a $8 \mathrm{~J} / \mathrm{cm} 2$ (que correspondem a 0,2 - 2J por ponto, 2-8J por dente) 3-6 aplicações mensais são eficientes para acelerar a movimentação ortodôntica. Esta intensa variação da densidade de energia é devido à diferença da área da ponta ativa dos aparelhos de laser.

Quando queremos estimular a movimentação de todos os dentes como demonstrado no trabalho de Camacho et al (2010), densidade de energia de $80 \mathrm{~J} / \mathrm{cm} 2$ ( que corresponde a 2,2J por ponto, 4,4J por dente ou aproximadamente $52,8 \mathrm{~J}$ por arco dentário) com uma aplicação mensal foi eficiente.

Partindo desta tendência observada no quadro 1, onde energias mais elevadas $(\mathbf{2}, \mathbf{3} \mathrm{J}$ por ponto/18,4J por dente) como demonstrado no trabalho de Limpanichkul et al (2006) não há estímulo, nem inibição para a movimentação ortodôntica em humanos, juntamente com os estudos de Goulart et al (2006) e Seifi et al. (2007) que observaram uma inibição na movimentação ortodôntica em animais com doses mais elevadas de LT, então, optamos por duplicar a energia utilizada por Limpanichkul et al (2006), ou seja: 4,2J por ponto, 42J por dente, com densidade de energia de $105 \mathrm{~J} / \mathrm{cm} 2$, com a intenção de promover a ancoragem ortodôntica.

Este raciocínio está fundamentado também na hipótese de que é possível que exista uma "janela terapêutica" (LOW; REED, 2001) que cause inibição da 
fotobioestimulação, descrito como conceito de Arndt-Schultz. Esta lei diz que o efeito do estímulo a uma célula viva é indiretamente proporcional a quantidade e intensidade do mesmo. Na mesma linha, Rudolf Arndt postulou a "Lei Básica da Biologia" na qual um estímulo leve iria acelerar a atividade vital, um estímulo médio elevaria a atividade vital, um forte suprimiria a atividade, enquanto que um estímulo muito forte cessaria por completo a atividade vital (LOW; REED, 2001), conforme gráfico 4 abaixo. Estas leis são também bases da homeopatia.

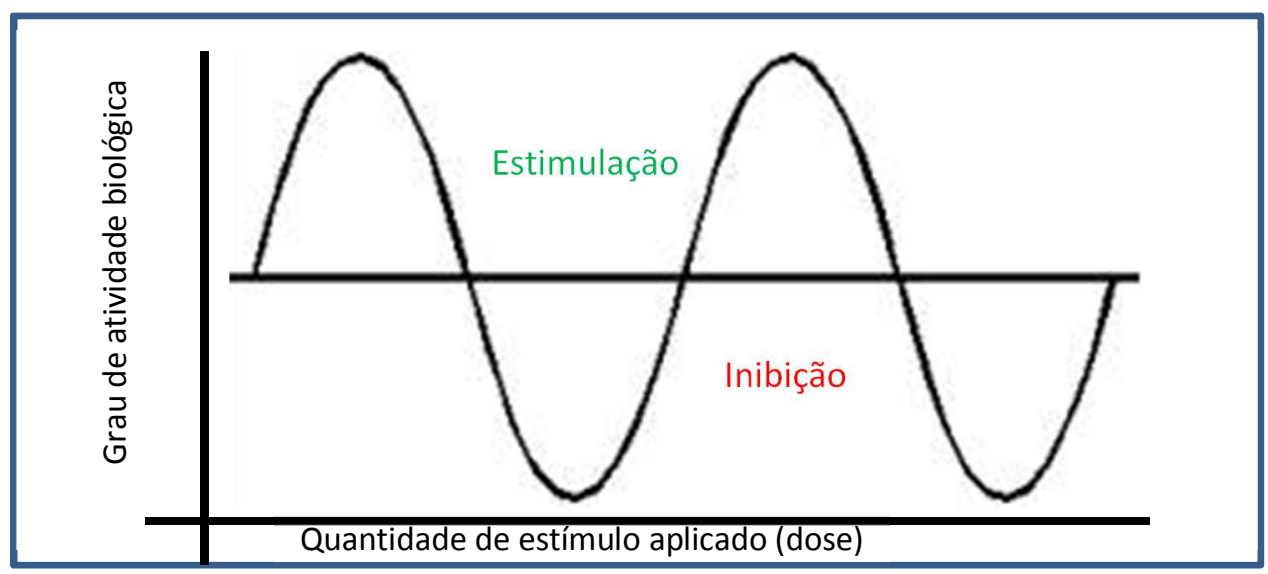

Gráfico 4 - Janela Terapêutica

\section{Efeito do LBI em relação à dose}

A dose que utilizamos já é consagrada na literatura no tratamento da parestesia, que é aplicada em todo trajeto do nervo alveolar inferior por vestibular, gengiva marginal vestibular, mesial e distal, mucosa lingual na direção do nervo alveolar inferior e gengiva marginal lingual, mesial e distal, sem nenhum efeito colateral nem dano deletério aos tecidos periodontais (BRUGNERA; GENOVESE; VILLA, 1991; GUTKNECHT; FRANZEN, 2004; DMC, 2005; GENOVESE, 2007; LIZARELLI, 2007). Este fato nos deu bastante segurança em utilizarmos esta dose, associado à literatura que afirma que os LBI emitem radiações de baixas potências, com energia menores que 2,0 elétron-volt $(\mathrm{eV})$, portanto, inferior à energia da ligação das moléculas biológicas e do DNA, de maneira a não promover quebras das ligações químicas e não induzir mutação e carcinogênese (BRUGNERA; ZANIN, 2001). 
Os nossos resultados demonstrados nas tabelas 7, 8 e 9 representam a perda de ancoragem dos molares irradiados comparados com os não irradiados por meio de modelos de estudo e das TCFC no período de avaliação de 90 dias, ou seja, para ambos os métodos de mensuração, houve uma diminuição da movimentação do lado irradiado estatisticamente significante em relação ao contralateral quando se compara o tempo total de tratamento (90 dias), porém para a análise nos modelos, somente no primeiro mês do experimento houve um retardo da movimentação estatisticamente significante no grupo de dentes irradiados comparados aos contralaterais.

Estes dados encontrados em modelos corroboram com os resultados encontrados por Gama et al (2010) em ratos que observaram que do primeiro ao sétimo dia do experimento houve um deslocamento menor no grupo laser do que 0 controle, embora não estatisticamente significante, enquanto que nos demais períodos o deslocamento entre ambos os grupos foi similar.

Gama et al (2010) atribuem este fato à força da mola ser maior no início do movimento, porém no nosso estudo, a força foi calibrada por um dinamômetro e as molas utilizadas foram de NiTi que dispensam forças mais controladas, além disso, se fosse devido à ativação inicial, este fato seria confirmado nos meses subsequentes em que reativamos a mola, o que não ocorreu.

Uma das possíveis justificativas para os resultados encontrados em modelos nos segundo e terceiro meses (sem diferenças estatísticamente significantes) talvez seja a necessidade de mais aplicações em intervalos regulares, ou seja, uma frequência maior de aplicação para que o efeito de ancoragem do LBI pudesse ser mantido e observado nos meses subsequentes. Como na reativação já temos no tecido periodontal um percentual residual de mediadores da movimentação prévia que somados à nova ativação resultaria num acúmulo maior de mediadores, então, talvez aplicações mais frequentes nos meses seguintes pudessem ter inibido a movimentação ortodôntica, mas isso são só hipóteses.

Consultando a literatura, uma das possíveis interferências do LBI na inibição relatado por Karu et al (1987) em experimentos em E.coli é que a medida que a dose é aumentada até uma determinada faixa de dose de luz, fotorreceptores da cadeia respiratória mitocondrial são afetados, acompanhados de uma diminuição do metabolismo celular, porém no nosso estudo, se este fato ocorreu, só se manifestou no primeiro mês do experimento. Como a movimentação ortodôntica envolve outros 
fatores supra e infracitados e por se tratar de um ensaio clínico, não foi possível verificar tal influência, então a constatação do experimento de Karu et al (1987) talvez não aconteça na complexidade da movimentação ortodôntica e mais estudos são necessários.

Outra possível causa seria a inibição do ácido araquidônico e consequentemente inibição das prostaglandinas, já demonstrado no estudo de Shimizu et al. (1995). As prostaglandinas induzem a dor, porém são necessárias para deflagar a resposta inflamatória indispensável para que a movimentação dentária ocorra.

Além disso, a diminuição da condução dos impulsos nervosos até o SNC (BENEDICENTI, 1982; KASAI et al., 1996) interferiria no limiar da resposta inflamatória, ou seja, a resposta inflamatória com a liberação de todos os mediadores envolvidos seria subestimada. Isto justificaria os resultados de inibição da movimentação e ao mesmo tempo da sintomatologia dolorosa observada em nosso estudo, corroborando com os resultados encontrados nos estudos de Sousa et al. (2011) e Angelieri et al. (2011) que observaram que com doses de energia mais baixas há um estímulo na movimentação ortodôntica, porém não há efeitos na inibição da dor.

Todas estas justificativas ainda são hipotéticas, pois a literatura é escassa nesta linha de pesquisa e mais estudos são necessários para que todas estas dúvidas sejam elucidadas.

\section{Efeito do LBI em relação à ancoragem e angulações dentárias}

De acordo com Nanda (1997), a máxima ancoragem foi definida como a perda de menos que $\mathbf{2 5 \%}$ de fechamento do espaço da extração por meio da perda de ancoragem posterior. De acordo com os nossos resultados (tabela 7,8,9), o LBI proporcionou uma ancoragem para o período de retração de caninos menor que 25\% (22,8\% em modelos e 16,7\% em TCFC), enquanto que os molares não irradiados tiveram uma perda de ancoragem maior que este percentual $(32,7 \%$ em modelos e $27 \%$ em TCFC).

OBS: Estes cálculos foram feitos considerando o espaço de $7 \mathrm{~mm}$ (100\%) correspondente à largura mésio-distal de um pré-molar, então 1,6mm (média da perda de ancoragem em modelos) corresponderia à $22,8 \%$ do fechamento do 
espaço da extração e 1,17mm (média da perda de ancoragem em tomografias) corresponderia à 16,7\%.

Obtivemos ainda uma perda de ancoragem menor $(\mathbf{1 , 1 7 - 1 , 6 m m})$ no período de retração dos caninos comparado aos estudos de Sharma et al. (2012) que utilizaram como dispositivo de ancoragem a barra transpalatina e obtiveram uma perda de ancoragem de 2,48 mm em média e de Lee e Kim (2011) que utilizaram além da barra transpalatina, o arco extra-bucal (média de 2,2mm).

A perda de ancoragem na fase de retração de caninos foi similar aos nossos resultados quando se utiliza botão de Nance, como no estudo de Shpack et al. (2008), cerca de 1,2-1,4mm

Especulamos que talvez se associássemos a laserterapia com a barra transpalatina e/ou o arco extra bucal ou então ao botão de Nance, obteríamos uma perda de ancoragem muito menos significante ou muito próxima do ideal, ou seja, praticamente nula.

Apesar do efeito de ancoragem ter se manifestado somente no primeiro mês do experimento, este se mostrou eficiente na fase de retração de caninos (90 dias), quando comparados os tempos inicial e final (tabelas 7,8,9), nos dois métodos de avaliação: por meio de modelos e por meio de TCFC. Portanto, o seu uso como recurso de ancoragem Ortodôntica na fase de retração inicial de caninos foi válido, porém mais estudos são necessários.

Outro cuidado adicional que tivemos foi verificar o efeito do LBI nas alterações promovidas pela retração inicial de caninos em relação às angulações dentárias, pois seria uma desvantagem se obtivéssemos um efeito positivo na ancoragem, porém com um excesso de angulações nos molares e caninos. Constatamos conforme tabela 10, que não houve diferenças estatisticamente significantes nestas variáveis comparando-se o lado irradiado com o lado não irradiado, ou seja, no período de tempo analisado o LBI promoveu uma ancoragem efetiva e ao mesmo tempo o comportamento dos molares e caninos do lado irradiado em relação à angulação foi similar ao contralateral.

Observamos ainda pelos resultados da tabela 10 que nos caninos inferiores a média da angulação do lado irradiado foi menor que o lado não irradiado, embora estatisticamente não significante, apesar dos valores de "p" estarem exatamente no limite $(p=0,05)$. Em contrapartida, o valor da média do movimento de retração dos caninos inferiores, embora estatisticamente não significante $(p=0,07)$ foi maior nos 
caninos do lado irradiado. Este comportamento dos caninos inferiores do lado irradiado (tendência a uma menor angulação e maior retração) talvez tenha ocorrido pelo fato dos caninos receberem indiretamente a energia de radiação do sistema de ancoragem. Para o movimento de angulação a energia recebida pelos caninos teve como efeito uma pequena "ancoragem", porém para o movimento de retração, o efeito foi o contrário, ou seja, houve um maior estímulo para o movimento distal dos caninos do lado irradiado, fato este justificado com a premissa de que com uma menor energia de irradiação há um maior estímulo à movimentação ortodôntica, fato este confirmado por alguns ensaios clínicos existentes na literatura (CRUZ et al., 2004; YOUSSEF et al., 2008; CAMACHO et al., 2010; SOUSA et al., 2011 e DOSHIMEHTA; GENC et al., 2012 e BHAD-PATIL., 2012).

Apesar da irradiação com altas energias para os molares e pré-molares $(4,2 \mathrm{~J}$ por ponto/ $42 \mathrm{~J}$ para molares/ $42 \mathrm{~J}$ para os segundos pré-molares) tendo como consequência um efeito de ancoragem, provavelmente a quantidade de energia que chegou até os caninos foi bem menor resultando num efeito inverso, ou seja, de estímulo da movimentação ortodôntica.

Isto seria uma grande vantagem na fase de retração inicial de caninos: ter uma dosimetria que proporcionasse ao mesmo tempo uma ancoragem nos molares e segundos pré-molares e um estímulo para a movimentação ortodôntica distal dos caninos. 


\subsection{Avaliação da integridade tecidual óssea por meio de TCFC}

Uma das preocupações deste estudo foi a verificação da integridade tecidual óssea e de quais efeitos a laserterapia poderia desencadear nos tecidos de suporte.

A literatura é unânime em afirmar que não há efeitos colaterais decorrentes da LT (BRUGNERA; ZANIN, 2001; GUTKNECHT; FRANZEN, 2004; LIZARELLI, 2007; SOUSA, 2008; PINHEIRO; BRUGNERA; ZANIN, 2010), porém pela diversidade de dosimetrias e pela escassez de trabalhos clínicos, não há estudos que comprovem este fato por meio de tomografias.

Há somente dois ensaios clínicos na literatura (CRUZ et al., 2004; SOUSA et al., 2011), porém ambos avaliaram a integridade tecidual por meio de radiografias periapicais.

Já foi relatado na revisão de literatura que a TCFC apresenta supremacia em relação às radiografias convencionais, principalmente na mensuração da perda da crista óssea alveolar (LUND; GRONDAHL; GRONDAHL, 2012) e reabsorção radicular (DUDIC et al., 2009; LUND et al., 2012; MAKEDONAS et al., 2012).

Uma das grandes vantagens das TCFC para avaliação da perda da crista óssea alveolar em relação às imagens radiográficas convencionais é a possibilidade de mensuração das faces vestibular e lingual, além das mesial e distal que tanto a radiografia quanto a tomografia possibilitam (MAKEDONAS et al., 2012), porém alguns fatores podem interferir na sua acurácia, como por exemplo, o tamanho do voxel. Patcas et al. (2012), verificando a acurácia das TCFC com diferentes resoluções: alta resolução $(0,125 \mathrm{~mm}$ voxel) e baixa resolução $(0,4 \mathrm{~mm}$ voxel), concluíram que ambas resoluções são eficientes para avaliação das cristas marginais.

Neste estudo, foram realizadas tomografias computadorizadas do feixe cônico com resolução de 0,4 $\mathrm{mm}$ de tamanho de voxel, portanto com uma boa resolução para avaliação das cristas marginais (PATCAS et al., 2012) e os dados da tabela 12 demonstraram não haver diferenças estatisticamente significantes entre o LI e o LNI para os dentes avaliados, exceto para as cristas ósseas vestibulares e distais dos primeiros molares superiores, onde se observou valores estatisticamente significante no lado irradiado (valores de p: 0,00* e 0,01*).

Se observarmos a tabela 12, a maioria dos valores da crista óssea alveolar do lado irradiado foi menor do que o lado não irradiado. Estes valores referem-se à 
diferença entre a distância da CA-JCE entre os tempos final e inicial, sendo assim, quanto menor o valor, menor a perda da crista óssea. Apesar desta tendência observada, apenas as cristas ósseas alveolares vestibulares e distais dos primeiros molares superiores apresentaram valores estatisticamente significantes $(-0,02$ e 0,09mm). O valor positivo $(0,09 \mathrm{~mm})$ encontrado para a crista óssea vestibular significa que houve uma perda óssea do lado irradiado, porém estatisticamente menor que o lado não irradiado e o valor negativo encontrado para a crista óssea alveolar da face distal do primeiro molar superior $(-0,02)$ significa que houve um ganho de altura de crista óssea no lado irradiado, mas de baixa importância clínica.

Estes dados corroboram as pesquisas realizadas por Xu et al. (2009), Ueda e Shimizu (2001) e Ozawa et al. (1998), que observaram em células osteoblásticas irradiadas que houve uma maior proliferação celular e aumento da atividade da fosfatase alcalina. Isto significa que esta dose, in vitro, aumentou a atividade metabólica de osteoblastos, refletindo numa maior formação óssea.

Se observarmos a movimentação dos primeiros molares superiores que serviram de ancoragem, houve uma movimentação para mesial e uma pequena giroversão no sentido vestíbulo lingual devido à ausência de dispositivos de ancoragem, ou seja, neoformação óssea na distal e vestibular e reabsorção óssea na mesial e lingual. Provavelmente a dose utilizada neste estudo tenha aumentado a atividade metabólica dos osteoblastos nos lados de neoformação óssea (crista óssea vestibular e distal).

Mas como se justificaria uma maior atividade metabólica dos osteoblastos com uma inibição da movimentação ortodôntica?

No estudo de Xu et al. (2009), no grupo de células irradiadas com 1,14J/cm² de densidade de energia, houve ao mesmo tempo um aumento da atividade metabólica dos osteoblastos, porém um aumento da expressão de OPG (inibidor de osteoclastos) e uma inibição da expressão de RANKL (ativador de osteoclastos) em relação ao grupo controle. Isto significa que esta dose, in vitro, além de proporcionar um aumento da atividade metabólica de osteoblastos, proporcionou também uma inibição da diferenciação de osteoclastos. Talvez este dado possa sugestionar o porquê do nosso estudo, apesar de ter ocorrido um aumento da crista óssea alveolar nos molares superiores nos lados de tração, houve 
ao mesmo tempo uma inibição da movimentação destes mesmos dentes submetidos à laserterapia.

Em relação à reabsorção radicular, não houve diferenças estatisticamente significantes em relação à reabsorção radicular nos dentes movimentados após 90 dias, comparando-se os lados irradiado com o não irradiado, conforme tabela 11. Os dentes que foram diretamente irradiados (molares e segundos prémolares) sofreram uma reabsorção radicular média de $\mathbf{0 , 2 2} \mathbf{m m}$, enquanto que os contralaterais sofreram uma reabsorção radicular média de $\mathbf{0 , 4 6} \mathbf{m m}$. Os dados encontrados para os contralaterais $(\mathbf{0 , 4 6} \mathbf{m m})$ não corroboram com os encontrados por Lund et al. (2012), que avaliaram a reabsorção radicular após movimentação ortodôntica sem qualquer influência e encontraram em $94 \%$ dos casos avaliados uma reabsorção maior que $1 \mathrm{~mm}$ em pelo menos um dente. Este fato se deve provavelmente pelo tempo de avaliação no nosso estudo que foi somente de 3 meses ao invés de 6 meses como no de Lund et al. (2012),. Além disso, no estudo de Lund et al (2012) foram avaliados todos os dentes do arco dentário, enquanto que neste estudo, foram avaliados somente os dentes envolvidos na movimentação (molares, pré-molares e caninos).

Os achados do nosso estudo corroboram com os dois únicos ensaios clínicos existentes na literatura que avaliaram os efeitos do LBI na reabsorção radicular durante a movimentação ortodôntica, porém avaliados em radiografias periapicais (CRUZ et al., 2004; SOUSA et al., 2011).

Inferimos pelos dados apresentados na tabela 11, que apesar de não haver diferenças estatisticamente significantes entre o lado irradiado e o não irradiado todos os valores encontrados para reabsorção radicular do lado irradiado foram menores que os valores encontrados para o lado não irradiados, havendo uma tendência de diminuição da reabsorção radicular sob a influência da laserterapia, porém mais estudos são necessários para confirmar esta tendência. 


\subsection{Considerações clínicas e propostas para estudos futuros}

Apesar da Ortodontia ter evoluído significativamente em diversas áreas nas últimas décadas, a dor e o tempo prolongado de tratamento tem sido uma constante preocupação para os profissionais e pacientes submetidos a este tipo de tratamento.

Em resposta a estas duas queixas principais, o LBI parece ter demonstrado sua eficácia.

Em relação às implicações clínicas, o movimento mais rápido dos dentes (CRUZ et al., 2004; YOUSSEF et al., 2008; CAMACHO; CUJAR, 2010; SOUSA et al., 2011; DOSHI-MEHTA; BHAD-PATIL, 2012; GENC et al., 2012) e redução do tempo de tratamento pode ser uma vantagem, especialmente para os adultos, uma vez que tempos mais longos de tratamento podem implicar em maiores chances de perda óssea alveolar, alterações gengivais e maior probabilidade à cáries.

Uma diminuição da sensibilidade devido ao movimento ortodôntico pode também ser obtida por meio da LT (LIM; LEW; TAY, 1995; TURHANI et al., 2006; TORTAMANO et al., 2009) dependendo da dose empregada e isto é uma grande vantagem, já que inúmeros pacientes são desestimulados a submeterem-se ao tratamento ortodôntico devido a este fator (NGAN; KESS; WILSON, 1989).

Além desses fatos, a laserterapia também pode funcionar para estimular $\mathrm{e}$ facilitar a movimentação dentária em difíceis situações clínicas, como em dentes não erupcionados, que serão submetidos à tração ortodôntica, distalização de molares ou nos mecanismos de retração da bateria de dentes anteriores. A aplicação de laser com doses de estimulação, especialmente nos casos mencionados, provavelmente facilitaria a movimentação dentária e, conseqüentemente, reduziria o tempo de tratamento.

A redução da dor e do tempo de tratamento seriam sem dúvida grandes vantagens do uso do LBI, além de ser um método simples de aplicação, indolor, não possui efeitos colaterais e de possuir pouquíssimas contra-indicações (BRUGNERA; GENOVESE; VILLA, 1991).

Oferecer ao paciente mais este benefício faz com que a Ortodontia ganhe mais um aliado, que diante de tantas vantagens oferecidas em relação a outros meios, é um diferencial frente a um mercado tão competitivo. 
Outra possibilidade que desponta é que com o aumento da dose de energia recebida pelo tecido ósseo alveolar e periodonto, o efeito poderá ser de inibição da movimentação, ou seja, a ancoragem, que nos favorece em diversas situações na Ortodontia, contribuindo desta forma para um tratamento mais rápido e efetivo, porém, até o momento isto só é possível num curto intervalo de tempo, como no caso da retração inicial de caninos que ocorre em aproximadamente 90 dias.

Por ser a aplicação de apenas uma luz e que não gera incômodos como os demais dispositivos intrabucais e extrabucais que são instalados, isto seria uma vantagem em relação aos outros sistemas de ancoragem, principalmente em relação aos mini-implantes que é considerado um dos sistemas de ancoragem mais invasivos e, portanto, de menor aceitação dos pacientes em geral. Outra vantagem seria a inibição da dor associada à ancoragem que esta dosimetria proporcionou. Assim, o paciente teria dois benefícios com um único recurso: a laserterapia, porém, o tempo de aplicação proposto neste estudo, seria uma desvantagem (1 min por ponto/ 8 pontos vest / 8 pontos ling: 16 minutos para cada lado), além dos retornos subsequentes para reaplicações ( 3 aplicações mensais).

$\mathrm{Na}$ realidade do mundo moderno, talvez este protocolo para ancoragem fosse inviável pelo tempo gasto e pela inexpressividade de resultados à longo prazo, o que torna o uso do laser como recurso de ancoragem desaconselhável para tratamentos que precisamos ancorar por mais tempo.

Outra desvantagem seria em casos que necessitamos de ancoragem máxima, pois apesar dos resultados demonstrarem o favorecimento da ancoragem com o LBI no período de retração inicial de caninos, não obtivemos a ancoragem absoluta. Se compararmos o LBI com os demais dispositivos de ancoragem existentes, como por exemplo, a barra transpalatina, o botão palatino de Nance e outros, observaremos que nenhum dispositivo garantirá a ancoragem absoluta (FELDMAN e BONDEMARK., 2006), porém para estes casos, os melhores resultados encontrados na literatura utilizaram os mini-implantes como recurso de ancoragem ( BENSON et al., 2007;LEE e KIM., 2011).

Estudos futuros poderiam investigar outros protocolos com menores tempos e maiores frequências tornando viável o seu uso clínico do LBI como recurso de ancoragem, além de protocolos de aplicação que garantam uma ancoragem a longo prazo. Além disso, para um maior entendimento dos achados desta pesquisa, poderse-ia pesquisar o fluido crevicular gengival após a aplicação de LBI utilizando-se 
doses de estimulação e de inibição verificando a presença de prostaglandinas e outros mediadores para que pudéssemos entender melhor os reais mecanismos de ação do LBI tanto na estimulação como na inibição da movimentação ortodôntica.

Poderíamos ainda investigar os efeitos do LBI na ancoragem Ortodôntica associado a outros dispositivos de ancoragem como, por exemplo, a barra transpalatina ou o arco lingual ou ainda os efeitos na reabsorção radicular pósmovimentação Ortodôntica, pois se a laserterapia diminuir a reabsorção radicular causada pela movimentação ("custo biológico") isto seria uma grande vantagem, mas ainda há um vasto campo de estudos a se percorrer e pelo que parece, a laserterapia associada à Ortodontia tem um futuro bastante promissor. 



\section{Conclusões}

"Duas coisas são infinitas: o universo e a estupidez humana. Mas, no que diz respeito ao universo, ainda não adquiri a certeza absoluta." Albert Einstein 



\section{CONCLUSÕES}

Com base na metodologia empregada, concluiu-se que na fase de retração dos caninos:

1. A laserterapia promoveu uma diminuição da movimentação da unidade de ancoragem de forma estatisticamente significante, somente no primeiro mês do início da retração, mas esta inibição refletiu-se durante todo o período avaliado;

2. Houve uma inibição da sintomatologia dolorosa na região da unidade de ancoragem em todos os meses avaliados do lado irradiado comparado ao lado não irradiado, com um maior percentual de redução de dor entre 24 a 48 horas.

3. Não houve reabsorção radicular e/ou reabsorção da crista óssea alveolar dos molares, pré-molares e caninos irradiados comparados aos dentes contralaterais não irradiados. 

Referências

"Não tentes ser bem sucedido, tenta antes ser um homem de valor."

Albert Einstein 



\section{REFERÊNCIAS}

Aihara N, Yamaguchi M, Kasai K. Low-energy irradiation stimulates formation of osteoclast-like cells via RANK expression in vitro. Lasers Surg Med. 2006;21:24-33.

Almeida-Lopes L. Laserterapia na odontologia. Biodonto. 2004;1(1):1-51.

Alqerban A, Jacobs R, Fieuws S, Willems G. Comparison of two cone beam computed tomographic systems versus panoramic imaging for localization of impacted maxillary canines and detection of root resorption. Eur $\mathrm{J}$ Orthod. 2011;33:93-102.

Andia DC, Cerri PS, Spolidorio LC. Tecido ósseo: aspectos morfológicos e histofisiológicos. R Odont Unesp. 2006;35(2):191-8.

Angelieri F, Sousa MVS, Kanashiro LK, Siqueira DF, Maltagliati LA. Efeitos do laser de baixa intensidade na sensibilidade dolorosa durante a movimentação ortodôntica. Dental Press J Orthod. 2011;16(4):95-102.

Araújo LHL, Zenóbio EG, Pacheco W, Cosso MG, Manzi FR, Shibli JA. Mass retraction movement of the anterior upper teeth using orthodontic mini-implants as anchorage. Oral Maxillofac Surg. 2012;16:95-9.

Arias OR, Marquez-Orozco MC. Aspirin, acethaminophen, and ibuprofen: their effects on orthodontic tooth movement. Am $\mathrm{J}$ Orthod Dentofacial Orthop. 2006;130(3):364-70.

Ariffin SHZ, Yamamoto Z, Abidin IZZ, Wahab RMA, Ariffin ZZ. Cellular and Molecular Changes in Orthodontic Tooth Movement. Scient World J. 2011;11:1788-803.

Artés-Ribas M, Arnabat-Dominguez J, Puigdollers A. Analgesic effect of a low-level laser therapy $(830 \mathrm{~nm})$ in early orthodontic treatment. Lasers Med Sci; 2012.

Ataka I. Studies of Nd:YAG low power laser irradiation on stellate ganglion. In: Ataka I, editors. Laser in Dentistry. Amsterdam: Elsevier; 1989. p. 271.

Benedicenti A. Manuale di laser del cavo orale. Gênova: Castelo Maggioli; 1982. 
Benedicenti S, Pepe IM, Angiero F, Benedicenti A. Intracellular ATP Level Increases in Lymphocytes Irradiated with Infrared Laser Light of Wavelength $904 \mathrm{~nm}$. Photomed Laser Surg. 2008;26(5):451-3.

Benson PE, Tinsley D, O'Dwyer JJ, Majumdar A, Doyle P, Sandler PJ. Midpalatal implants vs headgear for orthodontic anchorage-a randomized clinical trial: Cephalometric results. Am J Orthod Dentofacial Orthop. 2007;132:606-15.

Bergius M, Kiliaridis S, Berggren U. Pain in orthodontics. J Orofac Orthop. 2000;61:125-37.

Bernhardt MK, Southard KA, Batterson KD, Logan HL, Baker KA, Jakobsen JR. The effect of preemptive and/or postoperative ibuprofen therapy for orthodontic pain. Am J Orthod Dentofacial Orthop. 2001;120(1):20-7.

Bicakci AA, Kocoglu-Altan B, Toker H, Mutaf I, Sumer Z. Efficiency of Low-Level Laser Therapy in Reducing Pain Induced by Orthodontic Forces. Photomed Laser Surg. 2012;30(8):460-5.

Borsos G, Vokó Z, Gredes T, Kunert-Keil C, Vegha A. Tooth movement using palatal implant supported anchorage compared to conventional dental anchorage. Ann Anatomy: Elsevier GmbH; 2012.

Bouwensa DG, Cevidanes L, Ludlow JB, Phillips C. Comparison of mesiodistal root angulation with posttreatment panoramic radiographs and cone-beam computed tomography. Am J Orthod Dentofacial Orthop. 2011;139:126-32.

Breitbart $\mathrm{H}$, Levinshal $\mathrm{T}$, Cohen N, Friedmann $\mathrm{H}$, Lubart R. Changes in calcium transport in mammalian sperm mitochondria and plasma membrane irradiated at 633 nm (HeNe laser). J Photochem Photobiol B. 1996;34(2-3):117-21.

Brugnera A, Ladalardo TCCGP, Cruz FM. Introdução. In: Brugnera A, Ladalardo TCCGP, Cruz FM, editors. Atlas de Laserterapia Aplicada à Clínica Odontológica. São Paulo: Editora Santos Ltda; 2003. p. 1-11.

Brugnera A, Zanin F. O Laser na odontologia. In: Rosenthal, E. editor. A Odontologia no Brasil no Século XX - História llustrada. São Paulo: Editora Santos Ltda; 2001. p. 208-14.

Brugnera AJ, Genovese WJ, Villa R. Laser em odontologia. São Paulo: Editora Pancast; 1991. 
Burstone CJ. The biomechanics of tooth movement. In: Kraus BS, Riedel RA, editors. Vistas in Orthodontics. Philadelphia: Lea \& Febiger; 1962.

Camacho AD, Cujar SAV. Acceleration effect of orthodontic movement by application of low-intensity laser. J Oral Laser Applications. 2010;10:99-105.

Castro IO, Alencar AHG, Valladares-Neto J, Estrela C. Apical root resorption due to orthodontic treatment detected by cone beam computed tomography. Angle Orthod. 2012;00(0):1-8.

Chang HW, Huang HL, Yu JH, Hsu JT, Li YF, Wu YF. Effects of orthodontic tooth movement on alveolar bone density. Clin Oral Invest. 2012;16:679-88.

Chumbley AB, Tuncay OC. The effect of indomethacin (an aspirin-like drug) on the rate of orthodontic tooth movement. Am $\mathrm{J}$ Orthod Dentofacial Orthop. 1986;89(4):312-4.

Collins MK, Sinclair PM. The local use of vitamina $D$ to increase the rate of orthodontic tooth movement. Am J Orthod Dentofacial Orthop. 1988;94(4):278-84.

Colls J. La terapia laser hoy. Centro de documentación laser de meditec. Barcelona, v. 15, p. 1-5, 1984.

Consolaro A. Movimentação dentária induzida: biologia aplicada à prática clínica. In: Consolaro A, editor. Reabsorções Dentárias nas Especialidades Clínicas. Maringá: Dental Press Editora; 2002. p. 221-57.

Consolaro A. Movimentação dentária induzida: mecanismos e implicações clínicas. In: Consolaro, A, editor. Reabsorções dentárias nas especialidades clínicas. 3ª.ed. Maringá: Dental Press Editora; 2012. p. 455-522.

Consolaro A, Maldonado VB, Santamaria Júnior M, Consolaro MFM-O. Origem das controvérsias sobre os analgésicos após a ativação dos aparelhos ortodônticos. Dental Press J Orthod. 2010;15(1):16-24.

Coombe AR, Ho CTG, Philips JR, Chapple CC, Yum LWP, Darendelier MA, et al. The effects of low level laser irradiation on osteoblastic cells. Clin Orthod Res. $2001 ; 4(1): 3-14$. 
Cruz DR, Kohara EK, Ribeiro MS, Wetter NU. Effects of low-intensity laser therapy on the orthodontic movement velocity of human teeth: a preliminary study. Lasers Surg Med. 2004;35(2):614-22.

Dahlberg G. Statistical methods for medical and biological students. New York: Intercience; 1940.

Davidovitch Z, Finkelson MD, Steigman S, Shanfeld JL, Montgomery PC, Korostoff E. Electric currents, bone remodeling, and orthodontic tooth movement. Am J Orthod Dentofacial Orthop. 1980;77(1):14-31.

DMC. Laserterapia: thera lase:manual do usuário. Introdução a laserterapia. São Paulo; 2005.

Dominguez $A$, Castro $P$, Morales $M$. An in vitro study of the reaction of human osteoblasts to low-level laser irradiation. J Oral Laser Applications. 2009;9:21-8.

Dortbudak O, Hass R, Mailath-Pokorny G. Bioestimulation of bone marrow cells with a diode soft laser. Clin Oral Impl Res. 2000;11:540-5.

Doshi-Mehta G, Bhad-Patil WA. Efficacy of low-intensity laser therapy in reducing treatment time and orthodontic pain: A clinical investigation. Am J Orthod Dentofacial Orthop. 2012;141:289-97.

Dudic A, Giannopoulou C, Leuzinger M, Kiliaridis S. Detection of apical root resorption after orthodontic treatment by using panoramic radiography and conebeam computed tomography of super-high resolution. Am J Orthod Dentofacial Orthop. 2009;135:434-7.

Eduardo CP, Lage-Marques JL, Zezell DM, Gouw-Soares S, Tanji EY, Pelino JE, et al. "Hands on" utilização clínica do laser. São Paulo; 2004.

Einstein A. Zur quantum teorie der strlunmg. Phis Z. 1917;18:121.

El-Beialy AR, Abou-El-Ezz AM, Attia KH, El-Bialy AM, Mostafae YA. Loss of anchorage of miniscrews: A 3-dimensional assessment. Am J Orthod Dentofacial Orthop. 2009;136:700-7.

El-Bialy T, Lam B, Aldaghreer S, Sloan AJ. The effect of low intensity pulsed ultrasound in a 3D ex vivo orthodontic model. J Dentistry. 2011;39:693-9. 
Esper MALR, Nicolau RA, Arisawa EALS. The effect of two phototherapy protocols on pain control in orthodontic procedure-a preliminary clinical study. Lasers Med Sci. $2011 ; 26: 657-63$.

Feldman I, Bondemark L. Orthodontic Anchorage. Angle Orthod. 2006;76(3):493501.

Fujihara NA, Hiraki KRN, Marques MM. Irradiation at $780 \mathrm{~nm}$ Increases Proliferation Rate of Osteoblasts Independently of Dexamethasone Presence. Lasers Surg Med. 2006;38:332-6.

Fujita S, Yamaguchi M, Utsunomiya T, Yamamoto H, Kasai K. Low-energy laser stimulates tooth movement velocity via expression of RANK and RANKL. Orthod Craniofac Res. 2008;11:143-55.

Gama SKC, Habib FAL, Monteiro JSC, Paraguassú GM, Araújo TM, Cangussú MCT, et al. Tooth Movement After Infrared Laser Phototherapy: Clinical Study in Rodents. Photomed Laser Surg. 2010;28(S2):S79-S83.

Garib DG, Raymundo Jr. R, Raymundo MV, Raymundo DV, Ferreira SN. Tomografia computadorizada de feixe cônico (Cone beam): entendendo este novo método de diagnóstico por imagem com promissora aplicabilidade na Ortodontia. Dental Press J Orthod. 2007;12(2):139-56.

Gartner LP, Hiatt JL. Tratado de histologia em cores. 3a. ed. Elsevier Editora Ltda; 2007.

Genc G, Kocadereli I, Tasar F, Kilinc K, El S, Sarkarati B. Effect of low-level laser therapy (LLLT) on orthodontic tooth movement. Lasers Med Sci. 21 February 2012 ed: Springer-Verlag london Ltd; 2012.

Genovese WJ. Introdução e características físicas da radiação laser. In: Genovese WJ, editor. Laser de baixa intensidade Aplicações terapêuticas em odontologia. 1. ed. Santos: editora Santos; 2007. p. 1-11.

Geron S, Shpack N, Kandos S, Davidovitch M, Vardimon AD. Anchorage Loss - A Multifactorial Response. Angle Orthod. 2003;73:730-7.

Gianelly AA. Leeway space and the resolution of crowding in the mixed dentition. Sem Orthod. 1995;1:188-94. 
Goulart CS, Nouer PRA, Martins LM, Garbin IU, Lizarelli RFZ. Photoradiation and orthodontic movement: experimental study with canines. Photomed Laser Surg. $2006 ; 24(2): 192-6$.

Graber TM, Vanarssall RL. Orthodontics, Current Principles and Techniques. In: Roth, R. H. editor. Treatment mechanics for the straight wire appliance. 2a. ed. St. Louis: Mosby; 1994. p. 685-711.

Grieve WG, Johnson GK, Moore RN, Reinhardt RA, DuBois LM. Prostaglandin E (PGE) and interleukin-I[3 (IL-Ifi) levels in gingival crevicular fluid during human orthodontic tooth movement. Am J Orthod Dentofacial Orthop. 1994;105(4):369-74.

Griffin RS, Woolf CJ. Farmacologia da analgesia. Porto Alegre: UFRGS; 2008.

Grunheid T, Schieck JRK, Pliska BT, Ahmad M, Larson BE. Dosimetry of a conebeam computed tomography machine compared with a digital x-ray machine in orthodontic imaging. Am J Orthod Dentofacial Orthop. 2012;141:436-43.

Gunduz E, Rodríguez-Torres C, Gahleitner A, Heissenberger G, Bantleon H-P. Bone regeneration by bodily tooth movement: dental computed tomography examination of a patient. Am J Orthod Dentofacial Orthop. 2004;125(1):100-6.

Gutknecht N, Franzen R. O laser: função, interação e segurança. In: Gutknecht N, Eduardo CP, editors. A odontologia e o laser. 1a. ed. Berlin: Quintessence Editora Ltda.; 2004. p. 25-60.

Hart A, Taft L, Greenberg SN. The effectiveness of differential moments in establishing and maintaining anchorage. Am $\mathrm{J}$ Orthod Dentofacial Orthop. 1992;102:434-42.

Haxsen V, Schikora D, Sommer U, Remppis A, Greten J, Kasperk C. Relevance of laser irradiance threshold in the induction of alkaline phosphatase in human osteoblast cultures. Lasers Med Sci. 2008;23:381-4.

Heimisdottir K, Bosshardt D, Ruf S. Can the severity of root resorption be accurately judged by means of radiographs? A case report with histology. Am J Orthod Dentofacial Orthop. 2005;128:106-9.

Houston WJB. The analysis of errors in orthodontic measurements. . Am J Orthod Dentofacial Orthop. 1983;83(5):382-90. 
Huskisson EC. Measurement of pain. Lancet. 1974;7889(2):1127-31.

Interlandi S. Ortodontia: bases para iniciação. Biologia da movimentação dentária. 4 ed. São Paulo: Artes Médicas; 1999. p. 435-9.

Japan RMi. Saiba o que é microsievert. Made in Japan 2011 [cited 19/11/2012]; Available from: http://www.insitejapan.com

Karu T. Photobiological Fundamentals of Low-Power Laser Therapy. Quantum Electronics. 1987;QE-23(10):1703-17.

Karu T. Effects of visible radiation on cultures cells. J Photochem Photobiol. 1990;52(6):1089-98.

Karu T. Primary and secondary mechanisms of action of visible to near-IR radiation on cells. J Photochem Photobiol. 1999;49:1-17.

Karu T. Structure of mitochondria and activity of their respiratory chain in subsequent generations of yeast cells exposed to He-Ne laser light. Izv Akad Nauk Ser Biol. 2005;6:672-83.

Karu T. Mitochondrial Signaling in Mammalian Cells Activated by Red and Near-IR Radiation. J Photochem Photobiol. 2008;84:1091-9.

Karu T, Kalendo G, Letokhov VS, Lobko VV. Biostimulation of HeLa cells by low intensity visible light 11 . Stimulation of DNA and RNA synthesis rate in wide spectral range: Nuovo Cimento; 1984.

Karu TI. Molecular mechanism of the therapeutic effect of low-intensity laser radiation. Lasers Life Sci. 1988;2(1):53-74.

Karu TI, Kalendo GS, Ketokhov VS, Lobko VV. Bioestimulation of HeLa cells by low intensity visible light. II Stimulation of DNA and RNA syntesis in a wide spectral range. Ikvantovaya Elektronika. 1983;10:1138-44.

Kasai S, Kono T, Yamamoto Y, Kotani H, Sakamoto T, Mito M. Effect of low-power irradiation on impulse conduction in anesthetized rabbits. J Clin Laser Med Surg. 1996;14(3):107-13. 
Kassák P, Sikurová L, Kvasnicka P, Bryszewska M. The Response of $\mathrm{Na+} / \mathrm{K}_{+-}$ ATPase of Human Erythrocytes to Green Laser Light Treatment. Physiol Res. 2006;55:189-94.

Kau CH, Palomo JM, Richmond S, Hans MG. Three-dimensional cone beam computerized tomography in orthodontics. J Orthod. 2005;32:281-92.

Kawasaki K, Shimizu N. Effects of low-energy laser irradiation on bone remodeling during experimental tooth movement in rats. Lasers Surg Med. 2000;26(3):282-91.

Kim YD, Kim SS, Hwang DS, Kim SG, Kwon YH, Shin SH, et al. Effect of Low-Level Laser Treatment After Installation of Dental Titanium Implant-Immunohistochemical Study of RANKL, RANK, OPG: An Experimental Study in Rats. Lasers Surg Med. 2007;39:441-50.

Kim YD, Kim SS, Kim SJ, Kwon DW, Jeon ES, Son WS. Low-level laser irradiation facilitates fibronectin and collagen type I turnover during tooth movement in rats. Lasers Med Sci. 2010;25:25-31.

Kobayashi K, Shimoda S, Nakagawa Y, Yamamoto A. Accuracy in Measurement of Distance Using Limited Cone-Beam Computerized Tomography. Int J Oral Maxillofac Implants 2004;19:228-31.

Kobayashi Y, Takagi H, Sakai H, Hashimoto F, Mataki S, Kobayashi K, et al. Effects of local administration of osteocalcin on experimental tooth movement. Angle Orthod. 1998;68(3):259-66.

Kola'rova' H, Ditrichova' D, Wagner J. Penetration of the Laser Light Into the Skin In Vitro. Lasers Surg Med. 1999;24:231-5.

Kotoe M, Yamaguchi A, Sakaguchi M, igarashi Y, Shimizu N. Effect of Ga-Al-As Laser Irradiation on COX-2 and CPLA2-a Expression in Compressed Human Periodontal Ligament Cells. Lasers Surg Med. 2010;42:489-93.

Krishnan V. Orthodontic pain: from causes to management - a review. Eur J Orthod. 2007;29:170-9.

Krishnan V, Davidovitch Z. Cellular, molecular, and tissue-level reactions to orthodontic force. Am J Orthod Dentofacial Orthop. 2006;129(4):469e.1-e.32. 
Kumar V, Ludlow JB, Mol A, Cevidanes L. Comparison of conventional and cone beam CT synthetized cephalograms. Dentomaxillofac Radiol. 2007;36(5):263-9.

Laakso EL, Cabot PJ. Nociceptive Scores and Endorphin-Containing Cells Reduced by Low-Level Laser Therapy (LLLT) in Inflamed Paws of Wistar Rat. Photomed Laser Surg. 2005;23(1):32-5.

Laakso EL, Cramond T, Richardson C, Galligan JP. Plasma ACTH and $\beta$-endorphin levels in response to low level laser therapy (LLLT) for myofacial trigger points. Laser Ther. 1994;6:133-41.

Lamichane M, Anderson NK, Rigali PH, Seldin EB, Will LA. Accuracy of reconstructed images from cone-beam computed tomography scans. Am J Orthod Dentofacial Orthop. 2009;136:156.e1-.e6.

Lascala CA, Panella J, Marques MM. Analysis of the accuracy of linear measurements obtained by cone beam computed tomography (CBCT-NewTom). Dentomaxillofac Radiol. 2004;33(5):291-4.

Lee AY, Kim YH. Comparison of Movement of the Upper Dentition According to AnchorageMethod: OrthodonticMini-Implant versus Conventional Anchorage Reinforcement in Class IMalocclusion. ISRN Dentistry. 2011:1-7.

Lee KJ, Park YC, Yu HS, Choi SH, Yoo YJ. Effects of continuous and interrupted orthodontic force on interleukin-1 and prostaglandin E2 production in gingival crevicular fluid. Am J Orthod Dentofacial Orthop. 2004;125(2):168-77.

Lee W. Experimental study of the effects of prostaglandin administration on tooth movement - with particular emphasis on the relationship to the method of PGE1 administration. Am J Orthod Dentofacial Orthop. 1990;98(3):231-41 .

Leite V, Contib AC, Navarro R, Almeida M, Oltramari-Navarro P, Almeida R. Comparison of root resorption between self-ligating and conventional preadjusted brackets using cone beam computed tomography. Angle Orthod. 2012;82:1078-82.

Levander $E$, Malmgren $O$. Evaluation of risk of root resorption during orthodontic treatment: A study of upper incisors. Eur J Orthod. 1982;10(1):30-8.

Lim HM, Lew KKK, Tay DKL. A clinical investigation of the efficacy of low level laser therapy in reducing orthodontic postadjustment pain. Am J Orthod Dentofacial Orthop. 1995;108(6):614-22. 
Limpanichkul W, Godfrey K, Srisuk N, Rattanayatikul C. Effects of low-level laser therapy on the rate of orthodontic tooth movement. Orthod Craniofac Res. 2006;9(1):38-43.

Linge L, Linge BO. Patient characteristics and treatment variables associated with apical root resorption during orthodontic treatment. Am J Orthod Dentofacial Orthop. 1991;99:35-43.

Liou EJW, Pai BCJ, Lin JCY. Do miniscrews remain stationary under orthodontic forces? Am J Orthod Dentofacial Orthop. 2004;126:42-7.

Lizarelli RFZ. Protocolos clínicos odontológicos. Uso do laser de baixa intensidade. 3a. ed. São Carlos: Gorham Design; 2007.

Lorenzoni DC, Bolognese AM, Garib DG, Guedes FR, Sant'Anna EF. Cone-Beam Computed Tomography and Radiographs in Dentistry: Aspects Related to Radiation Dose. Int J Dent. 2012;813768:1-10.

Lotzof LP, Fine HA, Cisneros GJ. Canine retraction: A comparison of two preadjusted bracket systems. Am J Orthod Dentofacial Orthop. 1996;110(2):191-6.

Low J, Reed A. Eletroterapia explicada - princípios e prática. 3a. ed. São Paulo: Manole; 2001. p. 389-409.

Ludlow JB, Davies-Ludlow LE, Brooks SL, Howerton WB. Dosimetry of 3 CBCT devices for oral and maxillofacial radiology: CB Mercuray, NewTom 3G and i-CAT. Dentomaxillofac Radiol. 2006;35(4):219-26.

Ludlow JB, Gubler M, Cevidanes L, Mol A. Precision of cephalometric landmark identification: cone-beam computed tomography vc conventional cephalometric views. Am J Orthod Dentofacial Orthop. 2009;136(3):312.e1-.e10.

Ludlow JB, Ivanovic M. Comparative dosimetry of dental CBCT devices and 64-slice CT for oral and maxillofacial radiology. Oral Surg Oral Med Oral Pathol Oral Radiol Endod. 2008;106:106-14.

Lund H, Grondahl K, Grondahl H-G. Cone beam computed tomography evaluations of marginal alveolar bone before and after orthodontic treatment combined with premolar extractions. Eur J Oral Sci. 2012;120:201-11. 
Lund H, Gröndahl K, Hansen K, Gröndahl HG. Apical root resorption during orthodontic treatment: A prospective study using cone beam CT. Angle Orthod. 2012;82(3):480-7.

Maciel RN. Fisopatologia da dor. In: Maciel RN, editor. Fisopatologia Básica. 1a. ed. ed. São Paulo: Santos editora; 2005. p. 215-35.

Mah JK, Huang JC, Choo H. Practical applications of cone-beam computed tomography in orthodontics. JADA. 2010;141:7S-13S.

Makedonas D, Lund H, Gröndahl K, Hansen K. Root resorption diagnosed with cone beam computed tomography after 6 months of orthodontic treatment with fixed appliance and the relation to risk factors. Angle Orthod. 2012;82(2):196-201.

Mao JJ, Wang X, Kopher RA. Biomechanics of craniofacial sutures-orthopedic implications. Angle Orthod. 2003;73:128-35.

Marklund M, Lerner UH, Persson M, M. R. Bradykinin and thrombin stimulate release of arachidonic acid and formation of prostanoids in human periodontal ligament cells. Eur J Orthod. 1994;16(3):213-21.

Marquezan M, Bolognese AM, Araújo MTS. Effects of Two Low-Intensity Laser Therapy Protocols on Experimental Tooth Movement. Photomed Laser Surg. 2010;28(6):757-62.

Martins RP, Buschang PH, Gandini Jr LG. Group A T-loop for differential moment mechanics: An implant study. Am J Orthod Dentofacial Orthop. 2009;135:182-9.

Mateos SB. Uma luz poderosa. Rev Assoc Paul Cir Dent. 2005;59(6):407-14.

Miotti F. The passive lingual arch in first bicuspid extraction. Angle Orthod. 1984;54:163-75.

Monteiro JSC, Oliveira SCPS, Lima MFF, Sousa JAC, Pinheiro ALB, Santos JN. Effect of LED Red and IR Photobiomodulation in Tongue Mast Cells in Wistar Rats: Histological Study. Photomed Laser Surg. 2011;29(11):767-71.

Montesinos M. Experimental effects of low power laser in encephalin and endorphin sinthesis. Laser J Euro Med. 1988;1(3):2. 
Mostafa YA, Weaks-Dybvig M, Osdoby P. Orchestration of tooth movement. Am J Orthod Dentofacial Orthop. 1983;83(3):245-50.

Motta WT. Fosforilação Oxidativa. Bioquímica básica. Autolab; 2003. p. 209-34.

Mozzo P, Procacci C, Tacconi A, Martini PT, Andreis IA. A new volumetric CT machine for dental imaging based on the cone-beam technique: preliminary results. Eur Radiol. 1998;8(9):1558-64.

Nanda R. Biomechanics in Clinical Orthodontics. Philadelphia: WB Saunders; 1997.

Neves FS, Freitas DQ, Campos PSF, Almeida SM, Haiter-Neto F. In vitro comparison of cone beam computed tomography with different voxel sizes for detection of simulated external root resorption. J Oral Sci. 2012;54(3):219-25.

Neves LS, Silva CMS, Henriques JFC, Cançado FH, Henriques RP, Janson G. A utilização do laser em ortodontia. Rev Dent Press Ortodon Ortop. 2005;10(5):149-56.

Ngan P, Kess B, Wilson S. Perception of discomfort by patients undergoing orthodontic treatment. Am J Orthod Dentofacial Orthop. 1989;96(1):47-53.

Nguyen E, Boychuk D, Orellana M. Accuracy of cone-beam computed tomography in predicting the diameter of unerupted teeth. Am $\mathrm{J}$ Orthod Dentofacial Orthop. 2011;140:e59-e66.

Oliveira DAAP, Oliveira RF, Zangaro RA, Soares CP. Evaluation of Low-Level Laser Therapy of Osteoblastic Cells. Photomed Laser Surg. 2008;26(4):401-4.

Orlando F. Influência do laser de baixa intensidade na movimentação e na ancoragem ortodôntica poe meio de tomografia computadorizada [dissertação]. São Bernardo do Campo (SP): Universidade Metodista de São Paulo - UMESP; 2010.

Owais Al, Rousan ME, Badran SA, Abu Alhaija ES. Effectiveness of a lower lingual arch as a space holding device. Eur J Orthod. 2010;33:37-42.

Ozawa Y, Shimizu N, Kariya G, Abiko Y. Low-Energy Laser Irradiation Stimulates Bone Nodule Formation at Early Stages of Cell Culture in Rat Calvarial Cells. Bone. 1998;22(4):347-54. 
Parkhouse RC. Rectangular wire and third-order torque: A new perspective. Am J Orthod Dentofacial Orthop. 1998;113:421-30.

Patcas R, Muller L, Ullrich O, Peltomaki T. Accuracy of cone-beam computed tomography at different resolutions assessed on the bony covering of the mandibular anterior teeth. Am J Orthod Dentofacial Orthop. 2012;141:41-50.

Peck JL, Sameshima GT, Miller A, Worth P, Hatchere DC. Mesiodistal Root Angulation Using Panoramic and Cone Beam CT. Angle Orthod. 2007;77(2):206-13.

Pereira MCMC, Pinho CB, Medrado ARP, Andrade ZA, Reis SRA. Influence of 670 $\mathrm{nm}$ low-level laser therapy on mast cells and vascular response of cutaneous injuries. J Photochem and Photobiol B: Biology 2010;98:188-92.

Petrelli E. Ortodontia Contemporânea. 2a. ed. Editora Sarvier; 1993.

Pinheiro ALB, Brugnera A, Zanin FAA. Aplicações do Laser na Odontologia. 1a. ed. São Paulo: Livraria Santos Editora Ltda; 2010.

Polat O, Karaman A. Pain control during fixed orthodontic appliance therapy. Angle Orthod. 2005;75(2):210-5.

Price DD, McGrath PA, Rafii A, Buchingham B. The Validation of Visual Analogue Scales as Ratio Scale Measures for Chronic and Experimental Pain. Pain. 1983;17:45-56.

Prieto MGL, Dainesi EA, Kawauchi MY. O uso do ultra-som na movimentação dentária induzida. Rev Dent Press Ortodon Ortop. 2005;10(5):83-98.

Proffit WR. Ortodontia Contemporânea. Rio de Janeiro: Guanabara Koogan; 2002.

Quimby ML, Vig KWL, Rashid RG, Firestone AR. The accuracy and reliability of measurements made on computer-based digital models. Angle Orthod. $2004 ; 74(3): 298-303$.

Quitero JC, Trosien A, Hatcher D, Kapila S. Craniofacial imaging in orthodontics: historical perspective, current status, and future developments. Angle Orthod. 1999;69(6):491-506. 
Ramos LVT, Furquim LZ, Consolaro A. A influência de medicamentos na movimentação ortodôntica - uma análise crítica da literatura. Dental Press J Orthod. 2005;10(1):122-30.

Reitan K. Effects of force magnitude and direction of tooth movement on different alveolar bone types. Angle Orthod. 1964;34(4):244-55.

Reitan K. Initial tissue behavior during apical root resorption. Angle Orthod. $1974 ; 44(1): 68-82$.

Ren Y, Maltha JC, Kuijpers-Jagtman AM. Optimum force magnitude to orthodontic tooth movement. Angle Orthod. 2003;73:86-92.

Ren Y, Vissink a. Cytokines in crevicular fluid and orthodontic tooth movement. Eur J Oral Sci. 2008;116:89-97.

Renno ACM, McDonnell PA, Parizotto NA, Laakso EL. The Effects of Laser Irradiation on Osteoblast and Osteosarcoma Cell Proliferation and Differentiation in Vitro. Photomed Laser Surg. 2007;25(4):275-80.

Ricci R. Estudo in vitro da bioestimalação de células endoteliais em resposta a diferentes dosimetrias do laser de semicondutor fosfeto de índio-gálio-alumínio. [dissertação]. São José dos Campos: Universidade do Vale do Paraíba; 2003.

Rochkind S, Rousso M, Nissan M, Villarreal M, Barr-Nea L, Rees DG. Systemics effects of low-power laser irradiation on the peripheral and central nervous system, cutaneous wounds, and burns. Lasers Surg Med. 1989;9:174-82.

Ryden $\mathrm{H}$, Bjelkhagen $\mathrm{H}$, Soder $\mathrm{P}$. The use of laser beams for measuring tooth mobility and tooth movements. J Periodontol. 1975;46(7):421-5.

Saito S, Shimizu N. Stimulatory effects of low-power laser irradiation on bone regeneration in mid palatal suture during expansion in the rat. Am $\mathrm{J}$ Orthod Dentofacial Orthop. 1997;111(5):525-32.

Santoro M, Galkin S, Teredesai M, Nicolay OF, Cangialosi TJ. Comparison of measurements made on digital and plaster models. Am J Orthod Dentofacial Orthop. 2003;124:101-5. 
Saracino S, Mozzati M, Martinasso G, Pol R, Canuto RA, Muzio G. Superpulsed Laser Irradiation Increases Osteoblast Activity Via Modulation of Bone Morphogenetic Factors. Lasers Surg Med. 2009;41:298-304.

Schmuth GP, Freisfeld M, Köster O, Schüller H. The application of computerized tomography (CT) in cases of impacted maxillary canines. Eur $J$ Orthod. 1992;14(4):296-301.

Scholz RP. The Radiology Decision. Semin Orthod 2011;17:15-9.

Seifi M, Shafeei HA, Daneshdoost S, Mir M. Effects of two types of low-level laser wave lenghts $(850 \mathrm{~nm}$ and $630 \mathrm{~nm})$ on the orthodontic tooth movements in rabitts. Lasers Med Sci. 2007;22:261-4.

Sharma M, Sharma V, Khanna B. Mini-screw implant or transpalatal arch-mediated anchorage reinforcement during canine retraction: a randomized clinical trial. J Orthod. 2012;39(2):102-10.

Shewinvanakitkul W, Hans MG, Narendran S, Palomo JM. Measuring buccolingual inclination of mandibular canines and first molars using CBCT. Orthod Craniofac Res. 2011;14:168-74.

Shimizu N, Mayahara K, Kiyosaki T, Yamaguchi A, Ozawa Y, Abiko Y. Low-Intensity Laser Irradiation Stimulates Bone Nodule Formation Via Insulin-Like Growth Factor-I Expression in Rat Calvarial Cells. Lasers Surg Med. 2007;39:551-9.

Shimizu N, Yamaguchi T, Goseki T, Shibata Y, Takiguchi H, Iwasawa T, et al. Inhibition of prostaglandin E2 and interleukin 1- $\beta$ production by low-power laser irradiation in stretched human periodontal ligament cells. J Dent Res. 1995;74(7):1382-8.

Shpack N, Davidovitch M, Sarne O, Panayi N, Vardimon AD. Duration and anchorage management of canine retraction with bodily versus tipping mechanics. Angle Orthod. 2008;78(1):95-100.

Smith KC. The photobiological basis of low level laser radiation therapy. Laser Ther. $1991 ; 3(1): 19-25$.

Smith RJ, Burstone CJ. Mechanics of tooth movement. Am J Orthod Dentofacial Orthop. 1984;85(4):294-307. 
Soma S, Matsumoto S, Higuchi Y, Takano-Yamamoto T, Yamashita K, Kurisu K, et al. Local and Chronic Application of PTH Accelerates Tooth Movement in Rats. J Dent Res. 2000;79(9):1717-24

Sousa MVS. Influência do laser de baixa intensidade na movimentação ortodôntica. [dissertação] São Bernardo do Campo: Universidade Metodista de São Paulo; 2008.

Sousa MVS, Maltagliati LA, Siqueira DF, Hino CT, Angelieri F. Laser de baixa intensidade: fundamentos físicos, biológicos e sua utilização em Ortodontia. Ortodontia SPO. 2010;43(3):296-304.

Sousa MVS, Scanavini MA, Sannomiya EK, Velasco LG, Angelieri F. Influence of low-level laser on the speed of orthodontic movement. Photomed Laser Surg. $2011 ; 29(3): 191-6$.

Sousa MVS, Vasconcelos EC, Janson G, Garib D, Pinzan A. Accuracy and reproducibility of 3-dimensional digital model measurements. Am $\mathrm{J}$ Orthod Dentofacial Orthop. 2012;142(2):269-73.

Stevens DR, Flores-Mir C, Nebbe B, Raboud DW, Heo G, Major PW. Validity, reliability, and reproducibility of plaster vs digital study models: Comparison of peer assessment rating and Bolton analysis and their constituent measurements. Am J Orthod Dentofacial Orthop. 2006;129(6):794-803.

Stolik S, Delgado JA, Anasagasti L, Pérez AM. Effective Thermal Penetration Depth in Photo-Irradiated Ex Vivo Human Tissues. Photomed Laser Surg. 2011;29(10):66975.

Storey E. The nature of tooth movement. Am J Orthod Dentofacial Orthop. 1973;63:292-314.

Storey E, Smith R. Force in orthodontics and its relation to tooth movement. Aust Dent. 1952;56:11-8.

Suomalainen A, Vehmas T, Kortesniemi M, Robinson S, Peltola J. Accuracy of linear measurements using dental cone beam and conventional multislice computed tomography. Dentomaxillofac Radiol. 2008;37(1):10-7.

Tafur J, Mills PJ. Low-Intensity Light Therapy: Exploring the Role of Redox Mechanisms. Photomed Laser Surg. 2008;26(4):323-8. 
Takano-Yamamoto T, Kawakami M, Kobayashi Y, Yamashiro T, Sakuda M. The effect of local application of 1,25-Dihdroxycholecalciferol on osteoclast numbers in orthodontically treated rats. J Dent Res. 1992;71(1):53-9.

Thebault B, Bedhet N, Behaghel M, Elamrani K. The benefits of using anchorage miniplates. Are they compatible with everyday orthodontic practice? Int $\mathrm{J}$ Orthod. 2011;9:353-87.

Theodoro LH, Milanezi FM, Garcia VG, Milanezi LA. Lasers em superfície radicular. Revista Robrac. 2001;10(30):9-13.

Thiruvenkatachari B, Pavithranand A, Rajasigamani K, Moon Kyungd HM. Comparison and measurement of the amount of anchorage loss of the molars with and without the use of implant anchorage during canine retraction. Am $\mathrm{J}$ Orthod Dentofacial Orthop. 2006;129:551-4.

Tong H, Kwon D, Shi J, Sakai N, Enciso R, Sameshima GT. Mesiodistal angulation and faciolingual inclination of each whole tooth in 3-dimensional space in patients with near-normal occlusion. Am J Orthod Dentofacial Orthop. 2012;141:604-14.

Torres MGG, Campos PSF, Segundo NPN, Ribeiro M, Navarro M, Crusoé-Rebello I. Avaliação de doses referenciais obtidas com exames de tomografia computadorizada de feixe cônico adquiridos com diferentes tamanhos de voxel. Dental Press J Orthod. 2010;15(5):42-3.

Tortamano A, Lenzi DC, Haddad ACSS, Bottino MC, Dominguez GC, Vigorito JW. Low-level laser therapy for pain caused by placement of the first orthodontic archwire: A randomized clinical trial Am $J$ Orthod Dentofacial Orthop. 2009;136(5):662-7.

Turhani D, Scheriau M, Kapral D, Benesch T, Jonke E, Bantleon HP. Pain relief by single low-level laser irradiation in orthodontic patients undergoing fixed appliance therapy. Am J Orthod Dentofac Orthop. 2006;130(3):371-7.

Turner RT, Hannon KS, Greene VS, Bell NH. Prednisone inhibits formation of corticol bone in sham operated and ovariectomized female rats. Calcif Tissue Int. 1995;56:311-5.

Ueda Y, Shimizu N. Pulse irradiation of low-power laser stimulates bone nodule formation. J Oral Sci. 2001;43(1):55-60. 
Vasheghani MM, Bayat M, Rezaei F, Bayat A, Karimipour M. Effect of Low-Level Laser Therapy on Mast Cells in Second-Degree Burns in Rats. Photomed Laser Surg. 2008;26(1):1-6.

Wakabayashi H, Hamba M, Matsumoto K, Tachibana H. Effect of irradiation by semiconductor laser on responses evoked in trigeminal caudal neurons by tooth pulp stimulation. Lasers Surg Med. 1993;13:605-10.

Wan S, Anderson RR, Parrish JA. Analytical modeling for the optical properties of the skin with in vitro and in vivo applications. J Photochem Photobiol. 1981;34(4):493-9.

Wang Y, He S, Yu L, Li J, Chen S. Accuracy of volumetric measurement of teeth in vivo based on cone beam computer tomography. Orthod Craniofac Res. 2011;14:206-12.

Wong A, Reynolds EC, West VC. The effect of acetylsalicylic acid on orthodontic tooth movement in the guinea pig. Am $J$ Orthod Dentofacial Orthop. 1992;102(4):360-5.

Wu ZH, Zhou Y, Chen JY, Zhou LW. Mitochondrial Signaling for Histamine Releases in Laser-Irradiated RBL-2H3 Mast Cells. Lasers Surg Med. 2010;42:503-9.

Xu M, Deng T, Mo F, Deng B, Lam W, Deng P, et al. Low-Intensity Pulsed Laser Irradiation Affects RANKL and OPG mRNA Expression in Rat Calvarial Cells. Photomed Laser Surg. 2009;27(2):309-15.

Xu TM, XiZhang X, Oh HS, Boyd RL, Korn EL, Baumrindf S. Randomized clinical trial comparing control of maxillary anchorage with 2 retraction techniques. Am J Orthod Dentofacial Orthop. 2010;138:544.e1-.e9.

Yamaguchi M. RANK. RANKL .OPG during orthodontic tooth movement. Orthod Craniofac Res. 2009;12:113-9.

Yamaguchi M, Fujita S, Yoshida N, Oikawa K, Utsunomiya T, Yamamoto $\mathrm{H}$, et al. Low-energy laser irradiation stimulates the tooth movement velocity via expression of M-CSF and c-fms. Orthodontic Waves. 2007;66:139-48.

Yamaguchi M, Hayashi M, Fujita S, Yoshida T, Utsunomiya T, Yamamoto $\mathrm{H}$, et al. Low-energy laser irradiation facilitates the velocity of tooth movement and the expressions of matrix metalloproteinase- 9 , cathepsin $\mathrm{K}$, and alpha(v) beta(3) integrin in rats. Eur J Orthod. 2010;32:131-9. 
Yamasaki K, Shibata Y, Imai S, Tani Y, Shibasaki Y, Fukuhara T. Clinical aplication of prostaglandin E1 (PGE1) upon orthodontic tooth movement. Am J Orthod Dentofacial Orthop. 1984;85:508-10.

Yao $Y L$, Feng $X P$, Jing $X Z$. The correlation between tooth pain and bioactivators changes in gingival crevicular fluid after applying orthodontic stress. Shanghai J Stomat. 2003;12(5):331-3.

Yoshida T, Yamaguchi M, Utsunomiya T, Kato M, Arai Y, Kaneda T, et al. Lowenergy laser irradiation accelerates the velocity of tooth movement via stimulation of the alveolar bone remodeling. Orthod Craniof Res. 2009;12:289-98.

Youssef M, Ashkar S, Hamade E, Gutknecht N, Lampert F, Mir M. The effect of lowlevel laser therapy during orthodontic movement: a preliminary study. Lasers Med Sci. 2008;23:27-33.

Zilberman O, Huggare JAV, Parikakis KA. Evaluation of the tooth size and arch width measurements using conventional and three-dimensional virtual orthodontic models.. Angle Orthod. 2003;73(3):301-6. 



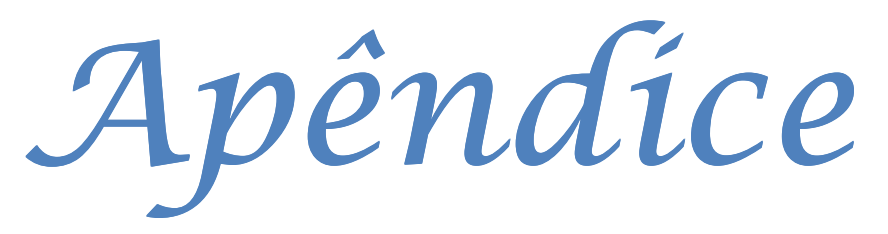

"O único lugar onde o sucesso vem antes do trabalho é no dicionário." Albert Einstein 



\section{APÊNDICE}

Este capítulo destina-se a esclarecer os princípios e fundamentos básicos da laserterapia

\section{Fundamentos físicos e dosimetria}

O laser é uma radiação que se encontra no espectro de luz que varia do infravermelho ao ultravioleta, passando pelo espectro visível (NEVES et al., 2005), possuindo, no entanto, algumas características especiais que a difere de outras fontes de luz, como uma lâmpada incandescente, por exemplo. A luz visível que se experimenta no dia-a-dia é apenas uma faceta de um fenômeno físico muito mais abrangente e conhecido como "radiação eletromagnética" (GENOVESE, 2007).

As emissões estão organizadas segundo o que se chama de "espectro de radiações eletromagnéticas", baseado em uma característica particular: o comprimento de onda, simbolizado pela letra lâmbda " $\lambda$ "(fig.21). Esse espectro é composto por radiações infravermelhas, radiações visíveis, radiações ultravioletas, radiações ionizantes (raios $x$ e raios gama), além de outros tipos de radiações. Os lasers utilizados para tratamento médico-odontológico emitem radiações que estão situadas na faixa das radiações visíveis, infravermelhas e ultravioletas e não são ionizantes (ALMEIDA-LOPES, 2004), com fótons de energia menores que 2,0 elétron-volt $(\mathrm{eV})$, portanto, inferior à energia da ligação das moléculas biológicas e do DNA, de maneira a não promover quebras das ligações químicas e não induzir mutação e carcinogênese (BRUGNERA; GENOVESE; VILLA, 1991).

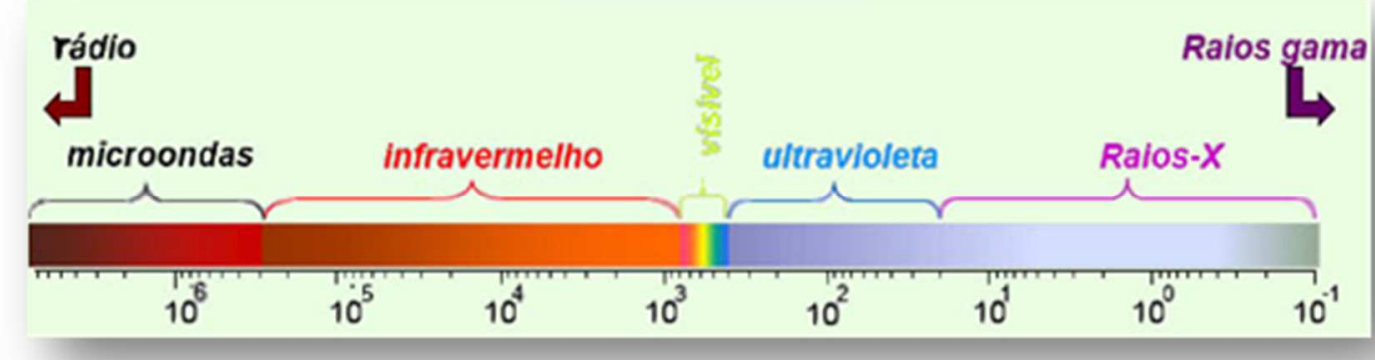

Figura 21 - Espectro eletromagnético (SOUSA et al., 2010) 
Para podermos identificar em que parte do espectro está classificada uma determinada radiação, precisamos conhecer seu comprimento de onda, que nada mais é do que a distância medida entre dois picos consecutivos de uma trajetória ondulatória (em forma de onda). A unidade para expressar essa grandeza é uma fração do metro, normalmente o nanometro, que é equivalente a 0.000000001 metros ou $1 \times 10^{-9} \mathrm{~m}$ (um bilionésimo do metro), e a freqüência de suas oscilações é medida em Hertz (Hz) (ALMEIDA-LOPES, 2004) (fig.22).

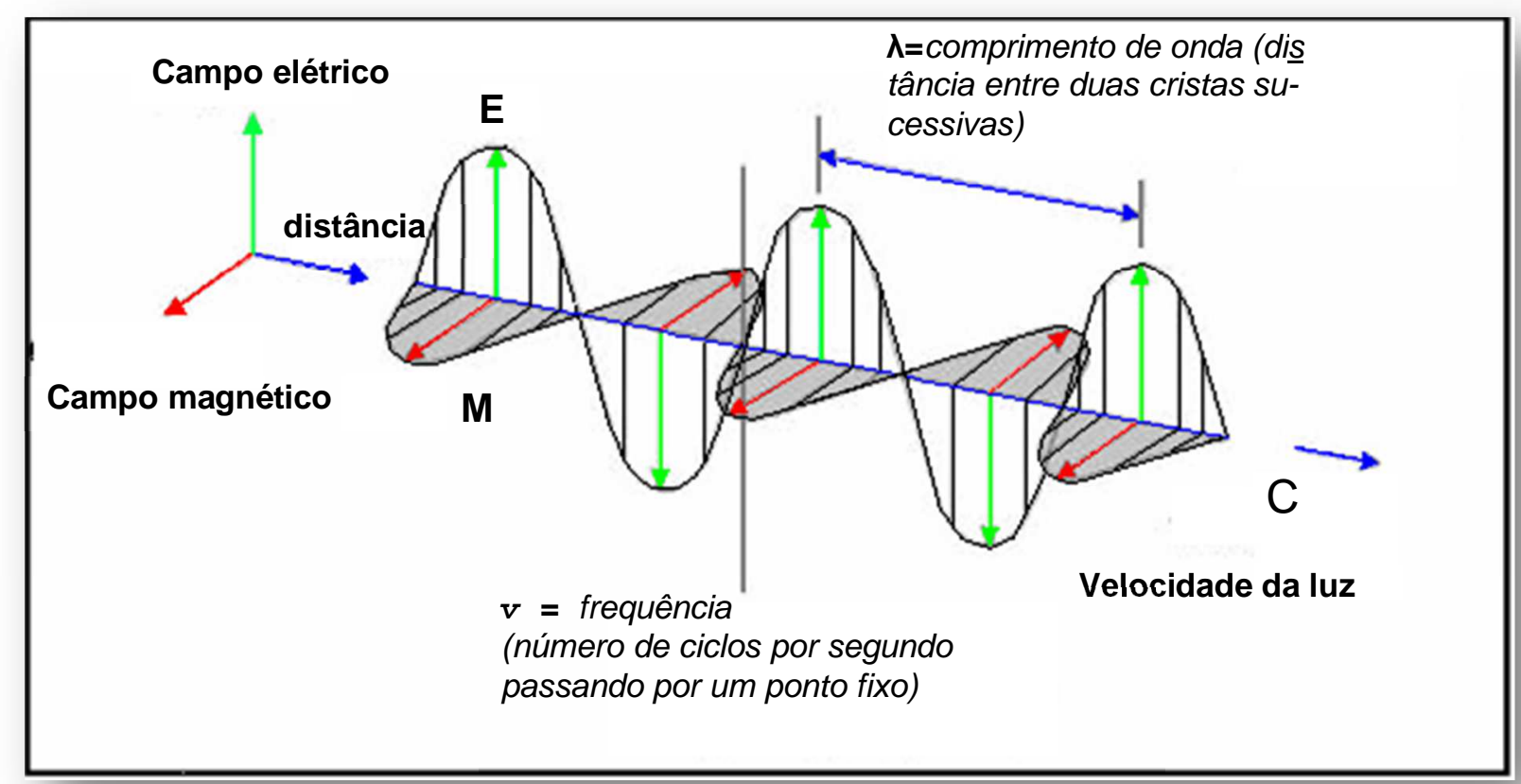

Figura 22- Comprimento de onda (www. geog.ufpr.br)

O comprimento de onda é uma característica extremamente importante, pois é ele quem define a profundidade de penetração da luz no tecido alvo.(fig.23) 


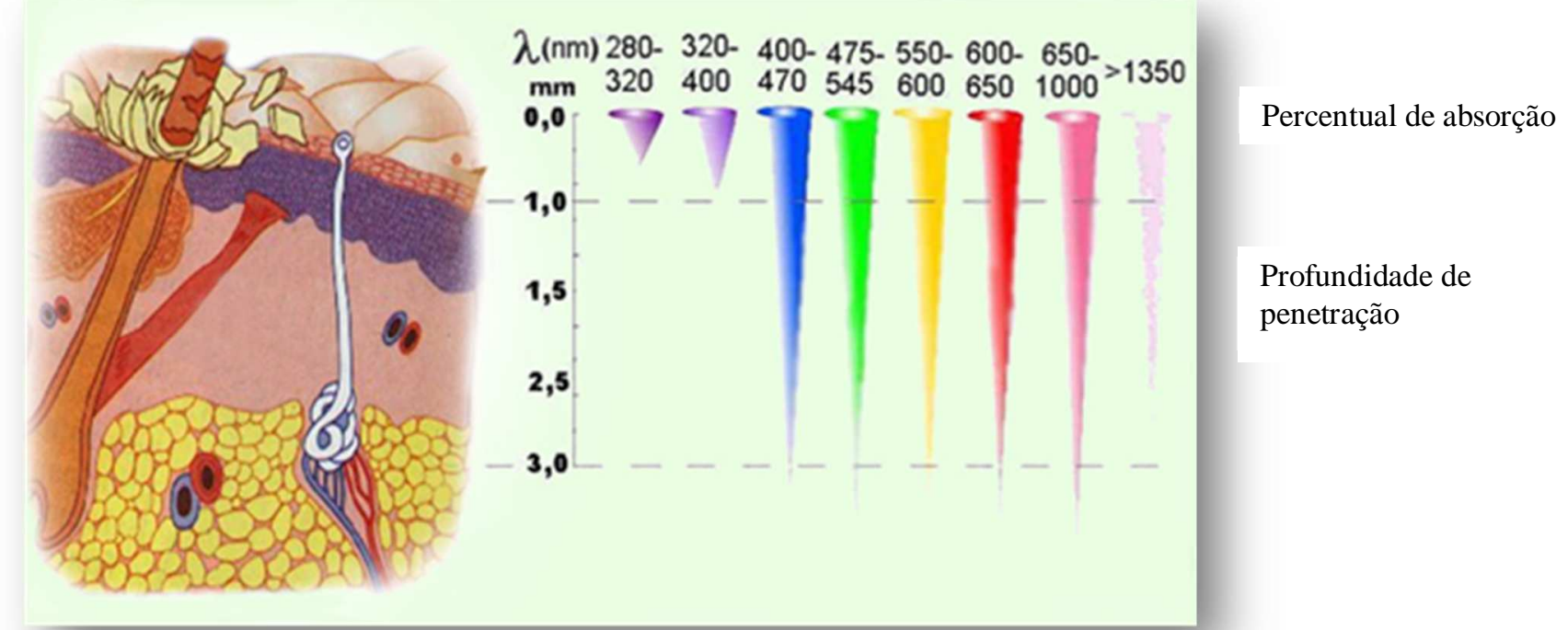

Figura 23 - Profundidade de penetração e percentual de absorção no tecido para os diferentes comprimentos de onda (SOUSA et al, 2010).

Comprimento de absorção é a distância na qual a intensidade inicial da luz cai para cerca de um terço da mesma. Pode-se afirmar que, em princípio, a profundidade de penetração da luz no tecido será tanto menor quanto maior for a absorção (GUTKNECHT; FRANZEN, 2004).

Considerando o espectro eletromagnético, os comprimentos de onda (ou cor da luz) mais empregados para realizar a laserterapia de baixa intensidade estão na faixa do vermelho (de 630 a $700 \mathrm{~nm}$ ) e infravermelho próximo (de 700 a $904 \mathrm{~nm}$ ) (LIZARELLI, 2007), que é uma faixa do infravermelho bem próxima ao vermelho visível, sendo possível sua visualização a "olho nu". Acima deste comprimento de onda $(904 \mathrm{~nm})$, torna-se necessário, nos aparelhos laser, uma luz diretriz para nos guiar, a fim de que possamos aplicar o feixe do laser no ponto desejado.

Para que seja possível entender, medir, escolher e controlar a irradiação dos tecidos a serem tratados, é necessário que se conheça o conceito de algumas grandezas físicas:

- Potência: informa a capacidade de um equipamento de fornecer energia, provocando maior ou menor reação fotobiológica (EDUARDO et al., 2004).

Potência $(\mathrm{W})=\underline{\text { Energia }(\mathrm{J})}$ Tempo (s) 
- Densidade de energia, fluência ou dose $\left(\mathrm{J} / \mathrm{cm}^{2}\right)$ : é a quantidade de energia aplicada no tecido com relação à área sobre a qual esta energia é aplicada, em outras palavras, é a distribuição da energia por unidade de área. A unidade, portanto, é $\mathrm{J} / \mathrm{cm}^{2}$ (Joule por centímetro quadrado) (LIZARELLI, 2007).

Densidade de energia $\left(\mathrm{J} / \mathrm{cm}^{2}\right)=\underline{\mathrm{P}(\mathrm{W}) \times \mathrm{T}(\mathrm{s})}$, sendo $\mathrm{P}$ a potência,

$$
A\left(\mathrm{~cm}^{2}\right)
$$

T o tempo de irradiação e A a área da ponta ativa "spot size" do aparelho a ser considerada quando o laser é entregue de forma pontual. No caso da caneta convencional da MMOptics, a área é $0,04 \mathrm{~cm}^{2}$ (LIZARELLI, 2007).

- Energia: quantidade de luz depositada no tecido tratado, sendo expressa em joules (J) (LIZARELLI, 2007).

Energia $(J)=$ Potência $(W) \times$ tempo $(\mathrm{s})$

Para se calcular a energia por ponto, quando temos a densidade de energia(DE) e a área do spot size $(A)$ do aparelho utilizado, basta multiplicar-se a densidade de energia pela área, como demonstrada na equação abaixo:

$E(J)=D E\left(J / \mathrm{cm}^{2}\right) \times A\left(\mathrm{~cm}^{2}\right)$

Para se calcular a energia total (Et), basta multiplicar-se a energia por ponto pelo número de pontos utilizado.

Etotal $=E(J) \times$ número de pontos utilizado

- Densidade de Potência, Irradiância ou Intensidade (W/ $\mathrm{cm}^{2}$ ) (LIZARELLI, 2007): é a razão com que a potência é dissipada numa certa área do tecido e pode ser calculada da seguinte forma:

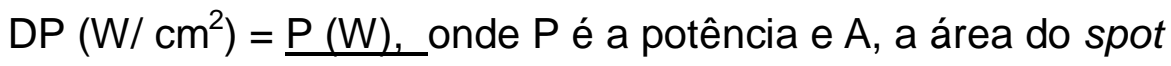

A

size do aparelho utilizado, no caso da aplicação ser de forma pontual.

Lizarelli (2007) salienta que é importante entender que um laser de potência alta, por exemplo, um laser cirúrgico de $20 \mathrm{~W}$, aplicado numa área de $10 \mathrm{~cm}^{2}$, teria uma irradiância de $2 \mathrm{~W} / \mathrm{cm}^{2}$. O mesmo laser, numa área de $1 \mathrm{~cm}{ }^{2}$, teria uma 
irradiância de $20 \mathrm{~W} / \mathrm{cm}^{2}$, o que ocasionaria dano térmico ao tecido se houvesse exposição prolongada, porque a mesma potência estaria sendo entregue numa área muito menor, e consequentemente a quantidade de energia por segundo, que seria absorvida pelo tecido, seria 20 vezes maior. Assim, não é a potência que determina dano térmico e sim, a irradiância.

Os primeiros protocolos que surgiram na literatura consideravam principalmente a fluência ou densidade de energia, expressa em $\mathrm{J} / \mathrm{cm}^{2}$, para comparação e indicação das doses entregues no tecido alvo, pois acreditava-se que independentemente da dimensão e configuração do feixe de luz laser, esta se espalhava no tecido abrangendo uma área de um centímetro quadrado (ALMEIDALOPES, 2004). Essa metodologia de cálculo tem sido abandonada, visto que esse "espalhamento" da luz laser ocorre de maneira distinta em tecido mole e tecido duro, ou em tecido mole pigmentado e em tecido mole sem pigmentação (DMC, 2005).

Recentemente, tem sido utilizada a área de secção transversal do feixe de luz laser ou "spot size" $\left(\mathrm{cm}^{2}\right)$ para cálculo da fluência, visando garantir protocolos estáveis (EDUARDO et al., 2004;' GENOVESE, 2007; LIZARELLI, 2007).

A energia poderá ser indicada tanto pela energia total $(\mathrm{J})$ quanto pela densidade de energia (dose ou fluência). Entretanto, utilizar a energia total como único parâmetro para o protocolo clínico não permite saber qual é a área do tecidoalvo, nem ao menos se a irradiação foi realizada por varredura ou por pontos. Além disso, não será possível saber qual foi a potência empregada, muito menos por quanto tempo. Por isso, necessita-se da menção da densidade de energia $\left(\mathrm{J} / \mathrm{cm}^{2}\right)$, mas ainda assim, deverá ser acrescida do comprimento de onda e da metodologia utilizada (por ponto ou varredura), além da área (diâmetro do "spot size") e outros dados, como energia total, energia por ponto, número de pontos, etc (LIZARELLI, 2007).

Além das grandezas físicas, é necessário que se conheça alguns termos relacionados a elas, como dosimetria e fotobiologia, bem como as características da luz laser que permite efeitos tão diferenciados sobre os tecidos em relação aos outros tipos de luzes. 
Dosimetria é o conjunto de manobras e táticas que o pesquisador/clínico utiliza para adequar a fonte de luz para que se possa entregar no tecido alvo a quantidade de energia mais eficiente para o tratamento (LIZARELLI, 2007).

Smith, K.C (1991) afirmou que todo bom trabalho em fotobiologia, ou seja, um estudo envolvendo os efeitos de uma determinada luz num dado tecido, deveria especificar tudo sobre a fonte de luz escolhida: comprimento de onda, potência de saída, densidade de energia, área irradiada, tempo de irradiação, entre outros, pois só assim o experimento poderá ser comparado, repetido ou tido como referência de apoio.

Vale salientar que, o laser nada mais é do que luz e, portanto tem o comportamento de luz, ou seja, pode ser refletido, absorvido ou transmitido, sofrendo ou não espalhamento no processo. Entretanto é uma luz com características muito especiais, tais como: unidirecionalidade, coerência e monocromaticidade (ALMEIDA-LOPES, 2004).

Monocromaticidade: a luz laser é composta de fótons, todos da mesma cor e todos com o mesmo comprimento de onda. É, portanto, uma luz pura (GENOVESE, 2007).(fig.24)

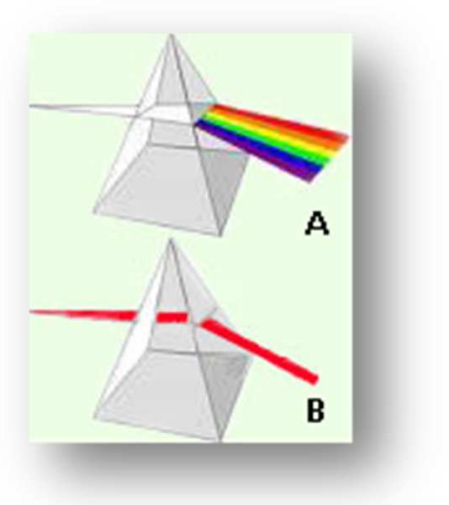

Figura 24 - Luz branca decomposta em cores individuais com o auxílio do prisma. A luz laser possui um só comprimento de onda, não se decompondo no prisma (SOUSA, et al., 2010).

Coerência: A luz laser é coerente, com fótons de mesmo comprimento de onda se propagando na mesma direção (em fase, no tempo e no espaço). Uma importante vantagem da luz laser ser coerente é a sua possibilidade de focalização 
em regiões diminutas, até o limite teórico do comprimento de onda do laser (limite de difração) (EDUARDO et al., 2004). (fig.25)

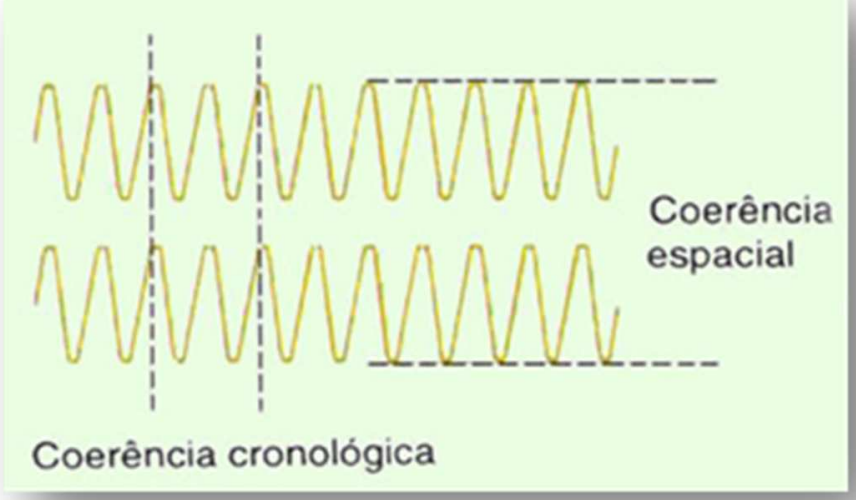

Figura 25 - Coerência cronológica: fótons do mesmo comprimento de onda. Coerência espacial: feixe em um só sentido (SOUSA et al., 2010).

Colimação ou direcionalidade: a luz laser é unidirecional e, por ser paralela ao eixo do tubo que produz esse tipo de energia, o feixe laser possui divergência angular muito pequena, ou seja, o feixe de fótons é paralelo. A pequena divergência permite que por meio de um sistema de lentes se consiga concentrar toda a energia do laser de uma forma precisa em um ponto focal, obtendo-se maior concentração de energia ou brilho. É o feixe colimado (GENOVESE, 2007).(fig.26)

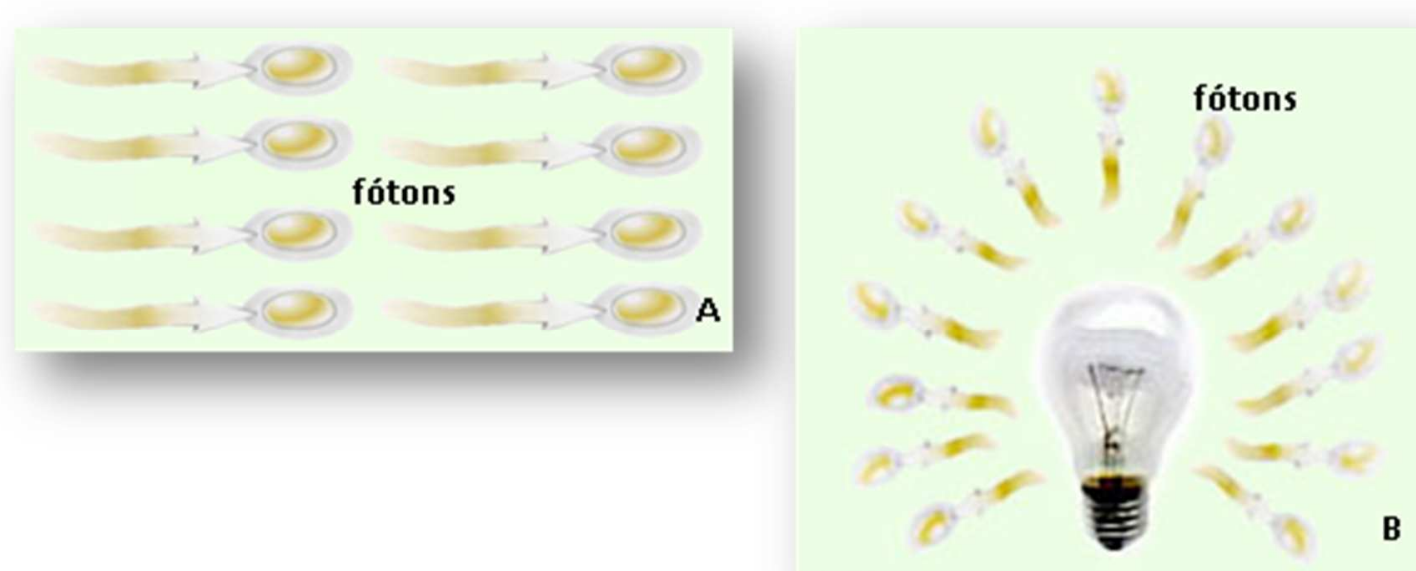

Figura 26 - Luz laser colimada (paralela); luz comum não colimada (divergente) (SOUSA, M. V. S., et al., 2010). 


\section{Tipos de lasers}

Os lasers dividem-se em dois grupos básicos, com efeitos distintos: os de alta potência ou cirúrgicos e os de baixa potência, também chamados de laser frio, laser terapêutico ou "soft-laser".

Os lasers de baixa intensidade (LBI) emitem radiações de baixas potências, e possuem uma ação analgésica, antiinflamatória (RYDEN; BJELKHAGEN; SODER, 1975; THEODORO et al., 2001; MATEOS, 2005) e de biomodulação tecidual (estimulação ou inibição). No caso da bioestimulação, por exemplo, os processos de multiplicação e regeneração celular podem ser acelerados, e no caso da inibição, pode-se diminuir parcial ou totalmente, a sintomatologia dolorosa. Lasers de baixa potência ou terapêutico têm inúmeras aplicações, as quais são baseadas sobretudo em efeitos fotoquímicos e/ou fotofísicos, que resultam do fato de as estruturas constituintes das células absorverem de forma seletiva os diversos comprimentos de onda de luz. Os componentes celulares cujo pico de absorção coincide com o comprimento de onda da radiação absorvem a maior parte da mesma, alterando-se ou destruindo-se. Dessa forma, ao invés de destruir células como o laser de alta potência, o de baixa desencadeia dentro delas uma série de reações químicas, acelerando alguns processos metabólicos e desacelerando outros. Entre os lasers de baixa potência encontram-se os lasers de He-Ne (Hélio-Neônio) e diodo (Arseneto de gálio - AsGa e Arseneto de gálio e alumínio - AsGaAl) (RYDEN; BJELKHAGEN; SODER, 1975; THEODORO et al., 2001; MATEOS, 2005).

O laser de diodo é uma radiação obtida a partir da estimulação de um diodo semicondutor formado por cristais de arseneto de gálio, arseneto de gálio e alumínio e fosfeto de índio-gálio-alumínio. Por semicondutor entende-se aquelas substâncias que, sem serem isolantes, possuem condutividade muito inferior aos metais (GENOVESE, 2007).

Essas estruturas cristalinas são dopadas com certa quantidade de material para que possam apresentar características elétricas diferentes:

- AsGa tipo P: dopado com zinco (Zn), eletropositivo

- AsGa tipo N: dopado com telúrio (Te), eletronegativo 
Unindo-se as duas estruturas cristalinas, temos um diodo semicondutor, onde a emissão da luz ocorre através da passagem da corrente elétrica pelo cristal semicondutor (BRUGNERA; GENOVESE; VILLA, 1991; GENOVESE, 2007) (fig. 27).

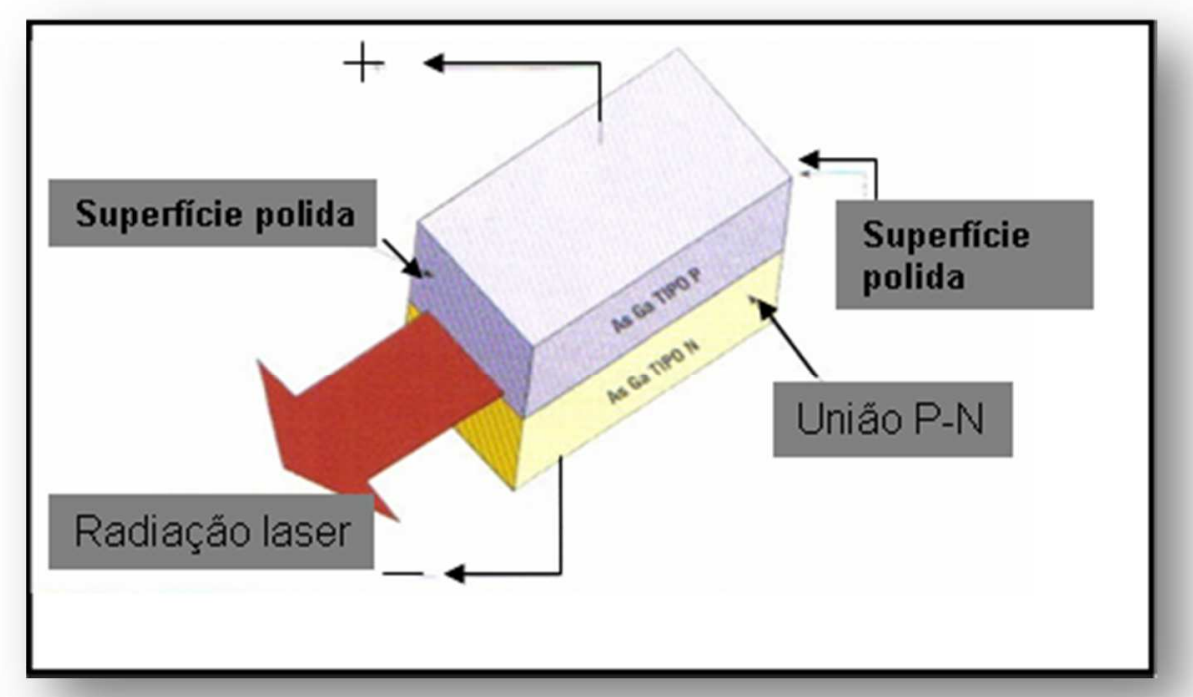

Figura 27 - Representação esquemática do LBI de diodo (GENOVESE, 2007)

\section{Métodos de irradiação}

Segundo Lizarelli (2007), o laser pode ser entregue de forma pontual ou por varredura.

Na forma pontual, o laser é aplicado em pontos eqüidistantes, cobrindo a área da lesão ou o ponto alvo e na forma de varredura, o laser "varre" de forma contínua e com velocidade média constante toda a extensão da área que se queira irradiar. Além disso, o laser pode ser aplicado em contato ou pode ser aplicado à distância (desfocado) do tecido alvo. No caso da ponta ativa estar em contato, haverá uma maior profundidade de penetração com mínima possibilidade de reflexão do laser (fig 28) (LIZARELLI, 2007).

O cálculo da dose ou fluência na forma pontual é realizado utilizando-se a área da ponta ativa do laser. O local da irradiação coincide com o local do trauma, enfermidade ou área que se queira atingir (LIZARELLI, 2007). 
Na forma de varredura utiliza-se para o cálculo da dose, a área da lesão ou região a ser irradiada, além disso o laser é aplicado em movimento contínuo e uniformemente acelerado, buscando entregar no tecido a mesma dose ao longo de toda a área (LIZARELLI, 2007). Trata-se de uma técnica pouco empregada atualmente, uma vez que é difícil, manualmente, manter a mesma aceleração do movimento, exceto nos casos onde o próprio equipamento laser é fabricado em forma de escaner, facilitando a técnica. Pode ser útil quando existir uma lesão muito extensa para ser bioestimulada, por exemplo, como nos casos de queimaduras superficiais e extensas (LIZARELLI, 2007).

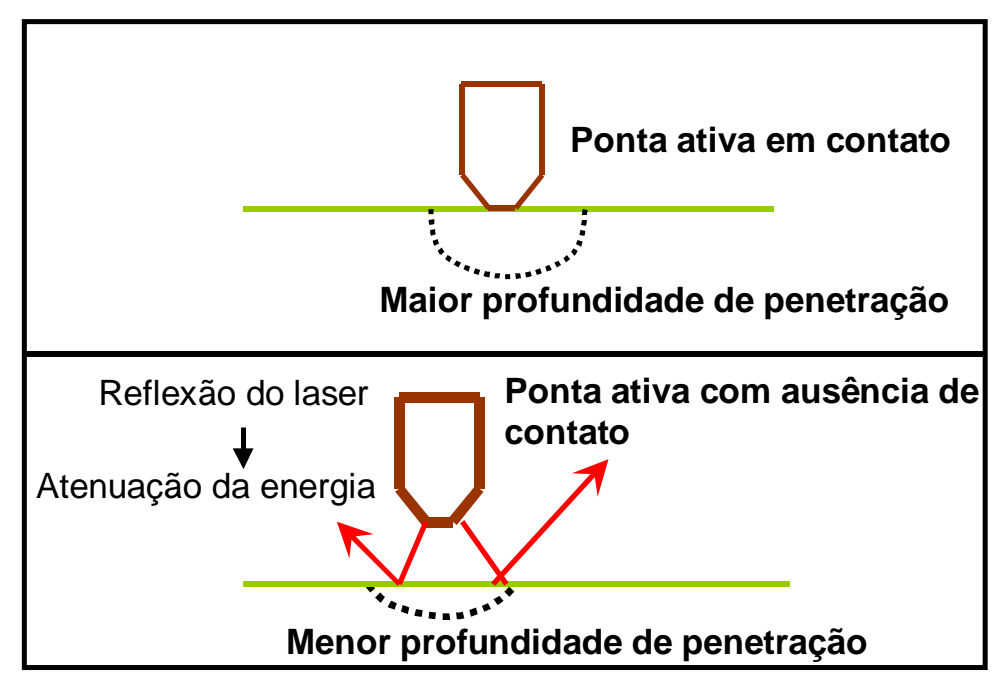

Figura 28 - Desenho esquemático mostrando a influência da forma de aplicação e distância da ponta ativa do tecido-alvo na profundidade de penetração do laser (LIZARELLI, 2007).

Utiliza-se a forma desfocada ou à distância quando se deseja diminuir a energia recebida pelo tecido alvo e existe um cálculo matemático para definir esta relação entre distância da ponta ativa/tecido alvo e quantidade de energia recebida pelo tecido. Este recurso é bastante utilizado quando possuímos um laser de alta potência, mas queremos que ele atue como laser em baixa potência, daí trabalha-se com o mesmo desfocado, para que se possa diminuir a energia recebida no tecido alvo (LIZARELLI, 2007). 


\section{Fundamentos biológicos do laser em baixa intensidade}

Quando a luz laser incide em um tecido biológico, uma parte da luz é refletida, uma parte da luz que foi transmitida, é espalhada dentro do tecido. Parte da luz remanescente é absorvida, tanto pela água no tecido ou por algum outro cromóforo absorvedor, como a hemoglobina e melanina. Finalmente uma parte da luz pode ser transmitida ao longo de toda a espessura do tecido (EDUARDO et al., 2004), conforme exemplificado na figura 29 (EDUARDO et al., 2004).

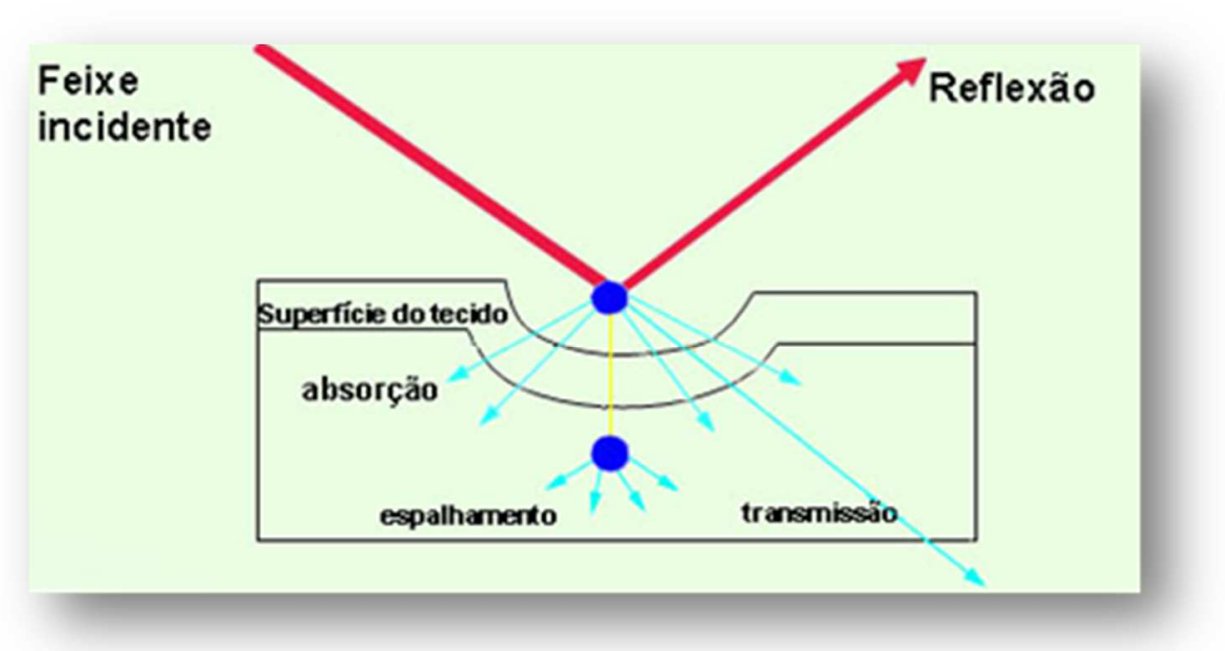

Figura 29 - Desenho esquemático mostrando as possibilidades de interação da luz com o tecido biológico (SOUSA et al, 2010).

Noventa por cento da luz incidente de um dado comprimento de onda é absorvido em uma certa profundidade característica e isto é conhecido como comprimento de extinção. Uma medida de absorção mais usual é o comprimento de absorção, que é o comprimento no qual $63 \%$ da luz incidente é absorvida (EDUARDO et al., 2004) e tem atuação no tecido-alvo, o restante desta luz é espalhada ou absorvida em outras regiões.

Diferentes comprimentos de onda apresentam diferentes coeficientes de absorção para um mesmo tecido (ALMEIDA-LOPES, 2004). (fig. 30) 


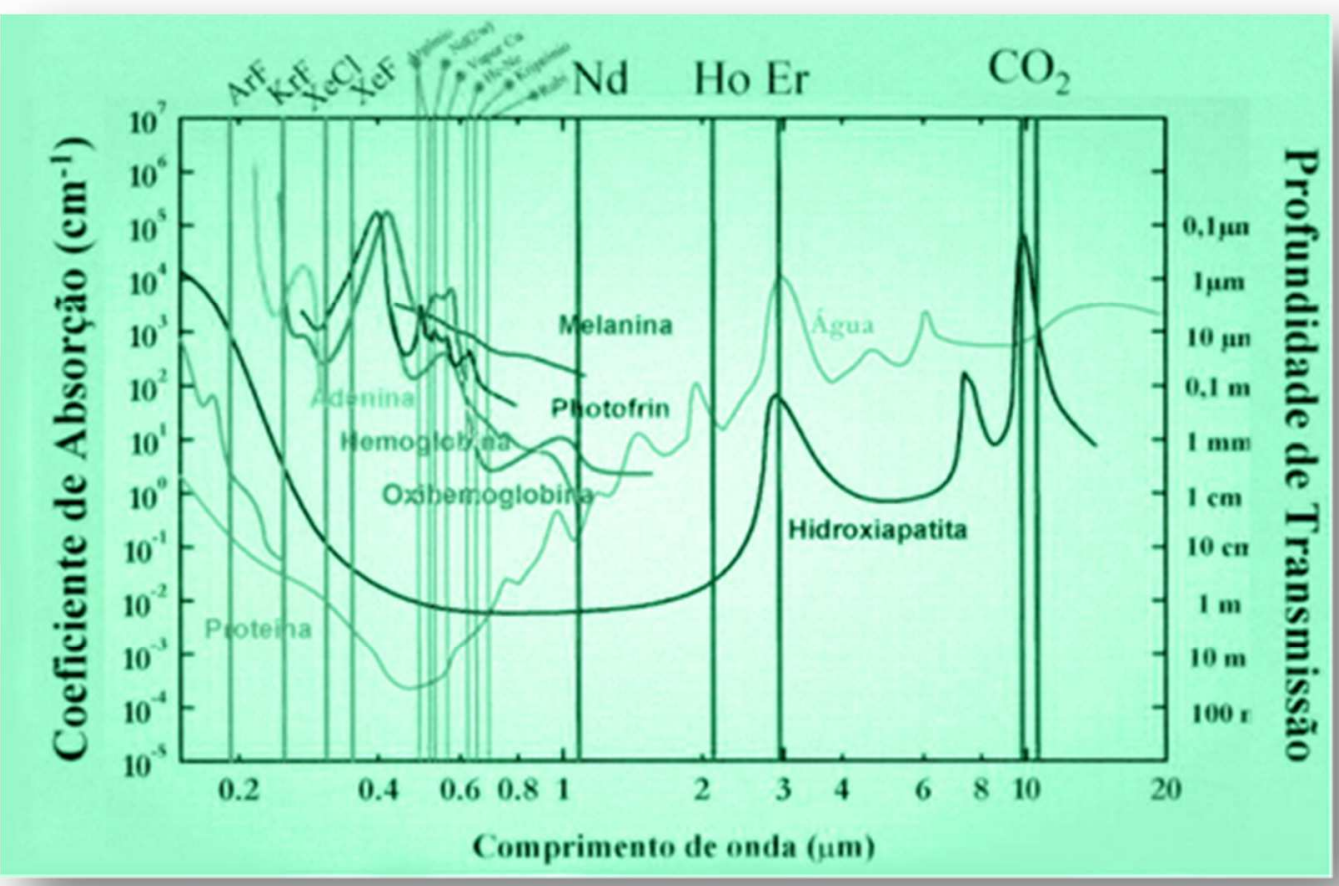

Figura 30 - Coeficientes de absorção para diferentes tecidos em função do comprimento de onda, proposto por Jacques em 1995 (SOUSA, et al., 2010).

Observamos na figura 30, por exemplo, que o laser de $\mathrm{CO}_{2}$ tem seu pico ótimo de absorção para hidroxiapatita, sendo portanto, um excelente laser quando se deseja trabalhar em tecido ósseo. Já o laser de Érbio (Er), tem seu pico ótimo de absorção para o elemento água, sendo bastante eficiente, quando trabalhamos em tecido mole. A presença de água na mucosa bucal permite uma alta absorção pelo laser de Érbio. O laser de diodo tem seu pico de absorção ótimo bem parecido com o laser de $\mathrm{HeNe}$, sendo bastante absorvido pela hemoglobina, oxihemoglobina, melanina, etc. É por este motivo que em indivíduos de pele mais pigmentada, quando aplicamos laser na epiderme, devemos aumentar um pouco a dose recomendada, pois parte da energia será absorvida pela melanina e portanto, não chegará à profundidade desejada.

A transmissão do laser através do tecido é altamente específica ao comprimento de onda, sendo ótima a janela óptica de 500 a 1200 nm (LIM; LEW; TAY, 1995; SAITO; SHIMIZU, 1997; KAWASAKI; SHIMIZU, 2000), onde na faixa de 400 a $700 \mathrm{~nm}$, encontra-se o vermelho visível e na faixa de 700 a 1200, o infravermelho (ALMEIDA-LOPES, 2004). O comprimento de onda de $780 \mathrm{~nm}$ do laser de diodo (GaAsAl) está nesta janela óptica e tem demonstrado possuir a maior 
penetração em tecidos humanos, quando comparado com outros sistemas de lasers (LIM; LEW; TAY, 1995; SAITO; SHIMIZU, 1997; KAWASAKI; SHIMIZU, 2000).

O laser vermelho por penetrar menos no tecido biológico é indicado para lesões superficiais, sendo o escolhido para reparos teciduais (cicatrização e drenagem local) (LIZARELLI, 2007). Além disso, esta luz tem como primeiro alvo as mitocôndrias das células, induzindo, portanto, a uma reação fotoquímica, ou seja, há uma direta ativação da síntese de enzimas (ALMEIDA-LOPES, 2004).

Adicionado a isto, o laser visível provoca outras reações nas mitocôndrias, com incremento na produção de ATP mitocondrial, aumento do consumo de glicose celular, aumento dos teores de cálcio intracelular e do número de mitocôndrias nas celulas (GENOVESE, 2007).

Os exatos mecanismos de ação da bioestimulação por meio do laser ainda são desconhecidos, mas alguns estudos como o de KARU et al (KARU et al., 1983), identificou o aparecimento do oxigênio singleto como radical livre após a radiação do laser. Como a formação de adenosina trifosfato (ATP) é influenciada pelo oxigênio livre singleto, então estes autores sugerem que este seria um dos mecanismos de bioestimulação.

O laser infravermelho, mais penetrante, é o comprimento de onda de eleição para reparos neurais e também quando se busca tecidos mais profundos (LIZARELLI, 2007), como por exemplo, o tecido ósseo. Diferente do vermelho visível, a luz no comprimento de onda do infravermelho é absorvida nas membranas celulares (ALMEIDA-LOPES, 2004), alterando seu potencial elétrico (LIZARELLI, 2007), induzindo a efeitos do tipo fotofísico e fotoelétrico, de forma a causar excitação de elétrons, vibração e rotação de partes da molécula ou rotação de moléculas como um todo, que se traduzem intracelularmente no incremento na síntese de ATP (ALMEIDA-LOPES, 2004). Contudo, independentemente de onde ocorra a fotorrecepção da luz, ambos os comprimentos de onda resultarão na transdução do sinal e amplificação do estímulo, gerando aumento de íons $\mathrm{Ca}^{++}$no citoplasma e aceleração da duplicação de DNA e da replicação de RNA no núcleo celular (LIZARELLI, 2007). A energia dos fótons de uma radiação laser absorvida por uma célula será transformada em energia bioquímica e utilizada em sua cadeia respiratória (LIZARELLI, 2007).

Segundo Kasai et al. (1996), o termo fotobioestimulação indica um estímulo induzido pela luz laser, capaz de provocar respostas físicas. Quando uma luz 
coerente de baixa energia encontra as moléculas do tecido e esta é parcialmente dissipada, sendo os fótons* (GUTKNECHT; FRANZEN, 2004) absorvidos pelos tecidos, ocorrem mudanças nas moléculas, átomos ou radicais livres, causando um estado de excitação. Esta interação fotomolecular é também chamada de fotobioativação, um termo que descreve o estado de excitação da molécula estimulada (KASAl et al., 1996).

KARU (1988), decreveu pela primeira vez um mecanismo de ação diferente para os lasers emitindo radiação na região do visível ao infravermelho próximo. As organelas não absorvem luz infravermelha, apenas as membranas apresentam resposta a este estímulo. Os incrementos de ATP mitocondrial, produzidos após a irradiação com laser, favorecem um grande número de reações que interferem no metabolismo celular. (fig. 31)
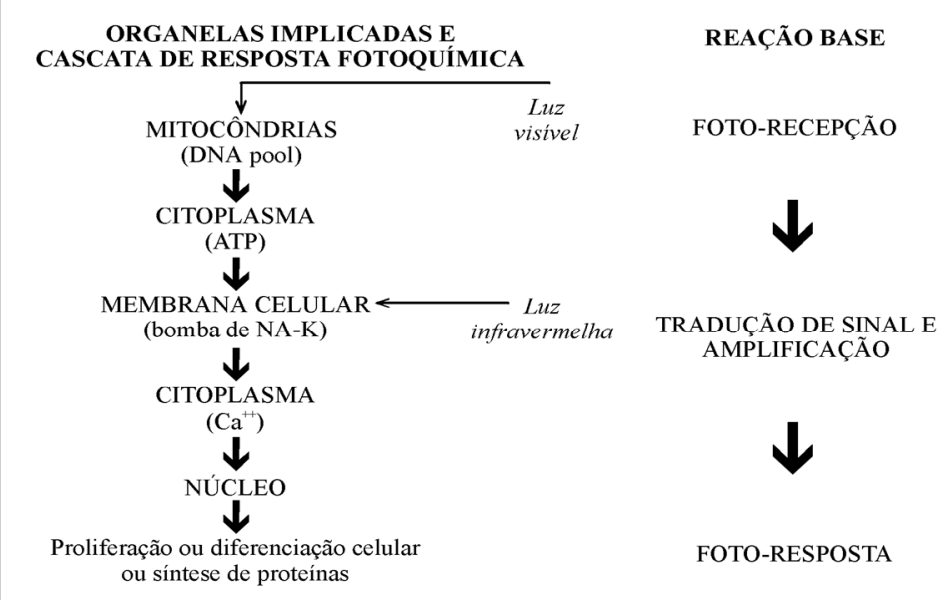

Figura 31 - Modelo de Karu (1988)

* Os fótons são partículas luminosas que se unem para formar uma "corrente luminosa", ou seja, uma onda eletromagnética. 
Desta forma, segundo o modelo de Karu (1998), tanto a luz visível, agindo nas mitocôndrias (síntese de DNA), como a luz infravermelha, agindo na membrana celular (bomba de $\mathrm{Na}-\mathrm{K}$ ), vai fazer com que haja um aumento do $\mathrm{Ca}^{++}$intracelular, que é um importante mensageiro para desencadear uma foto-resposta, que pode ser traduzida por meio de proliferação ou diferenciação celular, ou síntese de proteínas.

Smith (1991), utilizou o modelo de Karu (1988) modificando-o para explicar a interação em nível celular dessa radiação. A luz infravermelha provoca alterações fotofísicas na membrana celular, gerando um aumento da permeabilidade aos íons $\mathrm{Ca}^{++}$, que são mensageiros intracelulares em muitos sistemas de transdução, como por exemplo, na síntese de DNA e RNA, resultando em proliferação celular. (fig. 32).

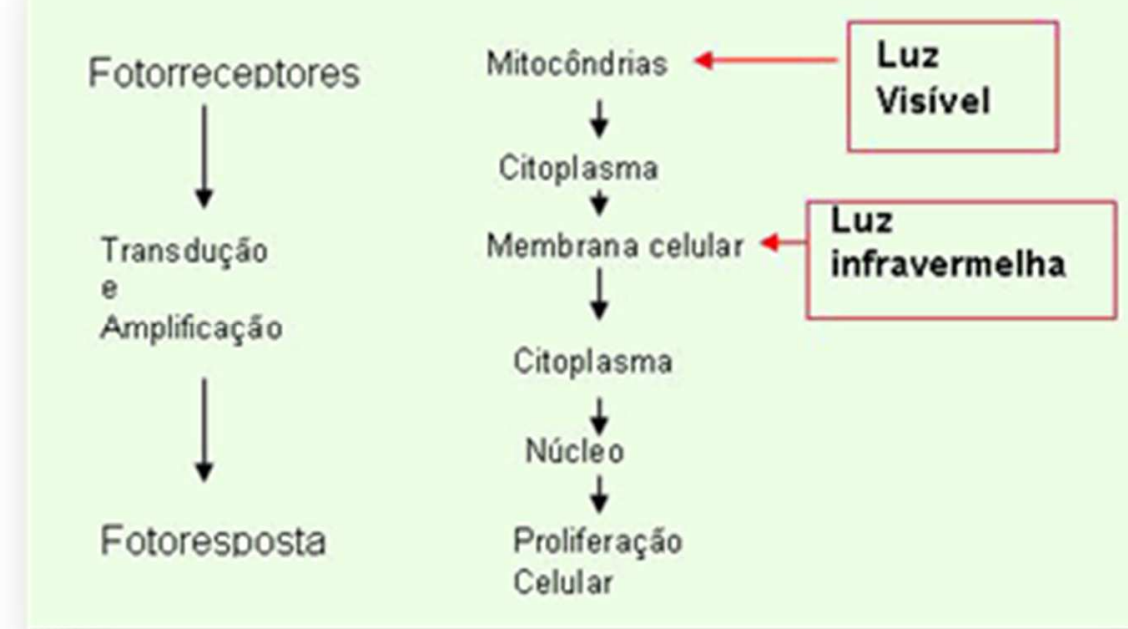

Figura 32 - Modelo de interação da luz de baixa intensidade com a célula (SOUSA et al, 2010).

Para se entender como são os efeitos biológicos da LT é indispensável o conhecimento da maneira como a energia laser é absorvida pelos tecidos. A identidade dos fotorreceptores responsáveis pelos efeitos biológicos do laser em baixa intensidade não são claramente descritos. Estudos sugerem que a absorção de fótons por parte da célula, seja diretamente por captação pelos cromóforos mitocondriais ou por ação em sua membrana celular (ALMEIDA-LOPES, 2004).

Os cromóforos, ou também denominados fotorreceptores consistem em um grupo de moléculas inter-relacionadas que podem ser enzimas, membranas celulares ou quaisquer outras substâncias intra ou extracelulares que apresentem a 
capacidade de absorver luz num determinado comprimento de onda, mas não são especializadas para isto (LIZARELLI, 2007).

A absorção da luz pelos cromóforos produz uma resposta biológica. Esta absorção é feita por uma molécula que poderá transferir energia para outras moléculas e com isso ativar outras, que poderão causar reações químicas nos tecidos (LIZARELLI, 2007).

Além disso, há relatos na literatura, relatos sobre os efeitos sistêmicos da irradiação laser (ROCHKIND et al., 1989).

Os lasers de baixa potência podem produzir efeitos em outras partes do corpo, além do local onde o laser é irradiado. Uma possível explicação para esse efeito sistêmico é que as células irradiadas no tecido, produzem substâncias que se espalham através dos vasos sanguíneos e do sistema linfático para outras partes do organismo (EDUARDO et al., 2004).

Rochkind et al (1989), num estudo experimental em ratos, observaram os efeitos sistêmicos do laser de HeNe, com comprimento de onda de $632,8 \mathrm{~nm}$. O laser foi testado em vários grupos de ratos submetidos a ferimentos por meio de incisões musculares em ambas as pernas (grupo A), queimaduras bilaterais (grupo B) e ferimento com exposição dos nervos periféricos bilaterais (grupo $\mathrm{C}$ ). Em todos estes grupos (A, B e C), o laser foi aplicado somente em um dos lados (perna direita ou esquerda). Para todos os grupos havia um grupo controle correspondente, em que as mesmas injúrias foram realizadas, porém o laser não foi aplicado. Em todos os grupos em que o laser foi aplicado, observaram-se recuperação dos tecidos injuriados de ambos os lados, porém com melhores resultados no lado em que o laser foi aplicado diretamente, enquanto que nos grupos controle correspondente, observou-se necroses e até gangrena bilateral. Desta forma, os autores concluíram que o laser pode ter efeitos sistêmicos, agindo não só no local aplicado (tecido-alvo). 
“Triste época! É mais fácil desintegrar um átomo do que um preconceito.” Albert Einstein 

ANEXO 1

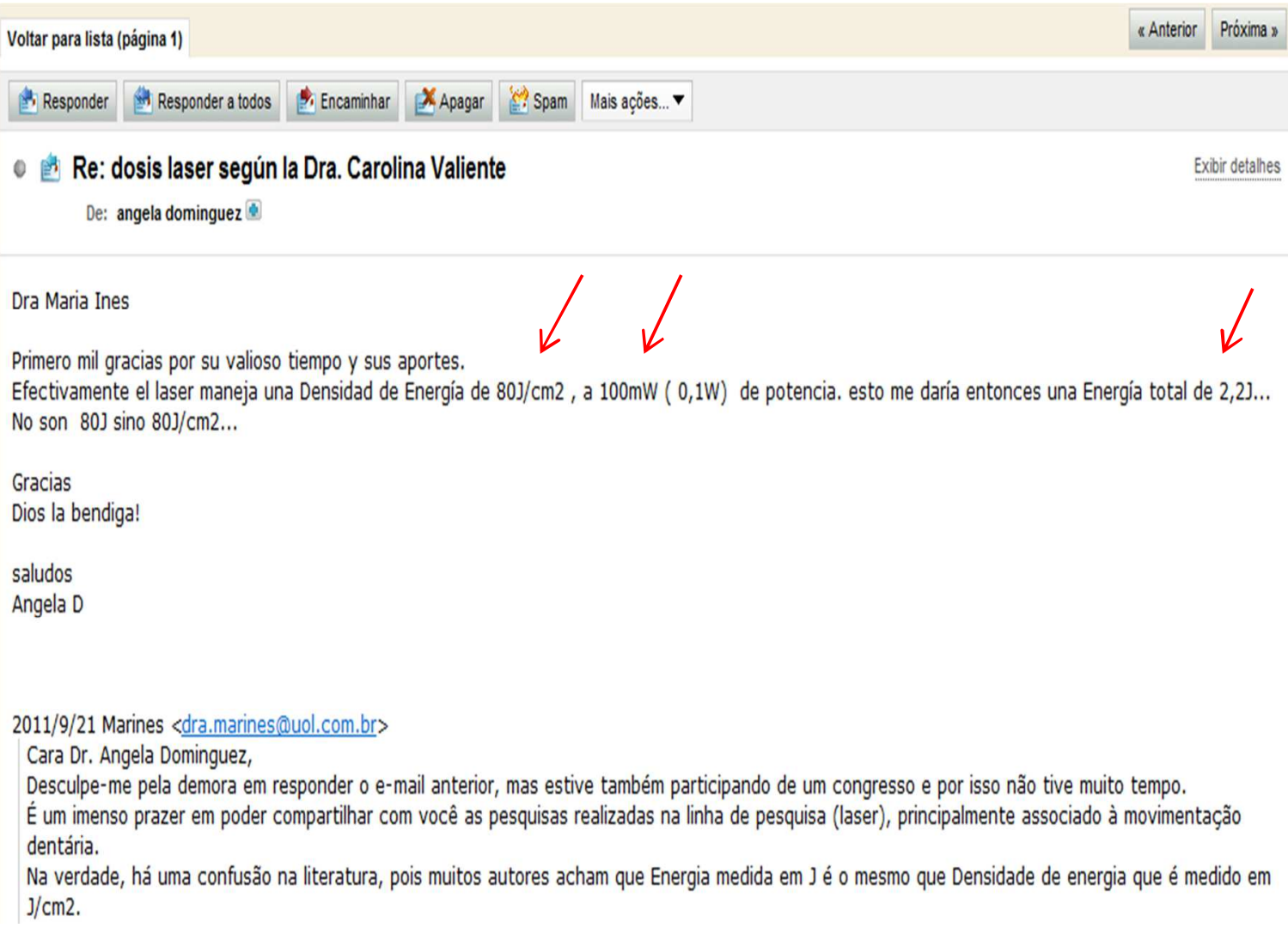

No artigo que publiquei há uma fórmula para o cálculo da energia e esta depende da ponta ativa ou "spot size" do aparelho em questão. Na verdade, o protocolo da DMC sugere $80 \mathrm{~J} / \mathrm{cm} 2$ de densidade de energia e não $80 \mathrm{~J}$ de energia, pois são cálculos diferentes.

Densidade de energia $D E=P(W) \times T(s)$,

onde a área é a ponta ativa do aparelho que estou us ando e a Energia é calculada pela seguinte $A(\mathrm{~cm} 2)$

förmula: $E=D E(J / \mathrm{cm} 2) \times A(\mathrm{~cm} 2)$ ou $E=P(W) \times \operatorname{tempo}(\mathrm{s})$.

No caso do aparelho da DMC, a área da ponta ativa ou "spot size" (A) do aparelho é $0,028 \mathrm{~cm} 2$, então se você usou 80 J de energia (E) no seu trabalho, a Densidade de Energia não dá para calcular, pois precisamos da potência, $D E=\underline{P(W) \times T(s)}=$ ? $\times 22$

$$
A(\mathrm{~cm} 2) \quad 0,028
$$

Qual a potência que você utilizou para que possamos fazer o cálculo da DE?

No meu trabalho que já te enviei, utilizei o laser da MMOptics que tem a área da ponta ativa de 0,04cm2, tempo de $10 \mathrm{~s}$ e potência de $20 \mathrm{~mW}$, que transformado em $W=0,02$ então

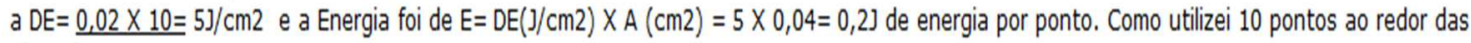
raízes dos 0,04

caninos, então obtive 2] de Energia Total.

Envio em anexo 0 artigo publicado sobre a explicação dos cálculos e a tabela de protocolos da DMC.

No seu trabalho você utilizou $80 \mathrm{~J}$ de Energia ou $80 \mathrm{~J} / \mathrm{cm} 2$ de densidade de energia?

Caso esteja confuso, estou à sua disposição.

Cordialmente,

Marinês 


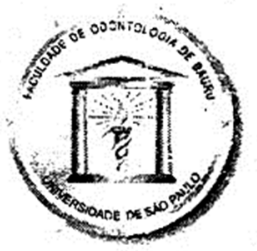

Processo no 133/2009

Bauru, 7 de julho de 2011.

\section{Universidade de São Paulo \\ Faculdade de Odontologia de Bauru}

Al. Dr. Octávio Pinheiro Brisolla, 9-75 - Bauru-SP - Brasil -CEP 17012-901 - C.P. 73

PABX (0XX14)3235-8000 - FAX (0XX14)3223-4679

Concitê de Ética em Pesquisa (14)3235-8356

e-mail: mferrari@fob.usp.br.

Senhor Professor,

Em atenção à solicitação de Vossa Senhoria para alterações no projeto de pesquisa "COMPARAÇĀO

DE DIFERENTES DOSIMETRIAS DO LASER DE BAIXA INTENSIDADE NA ACELERAÇÃO DA MOVIMENTAÇÃO ORTODÔNTICA", de autoria de Marinês Vieira da Silva Sousa, sob sua orientação, informamos que foi analisada por um relator e analisada em reunião, deste Comitê de Ética em Pesquisa, realizada no dia 6 de julho de 2011.

O CEP-FOB/USP considerou as alterações do projeto APROVADAS lembrando que a condição de aprovação da pesquisa propriamente dita exige $o$ que segue:

- que sejam encaminhados ao CEP-FOB/USP relatórios anuais sobre o andamento da pesquisa (parciais e finais), conforme o cronograma apresentado;

- que sejam notificados ao CEP-FOB/USP, com a devida justificativa, qualquer modificação na metodologia e/ou título e a inclusã̃o ou exclusão de autores;

- na apresentação do relatório final, incluir todoș os TCLEs e/ou termos de doação de dentes devidamente assinados e rubricados.

Atenciosamente,
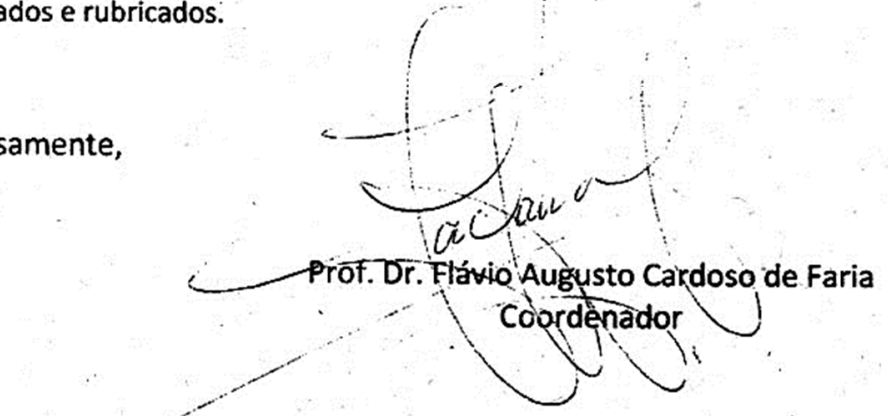

Prof. Dr. Arnaldo Pinzan

Docente do Departamento de Odontopediatria, Ortodontia e Saúde Coletiva 
ANEXO 3

TERMO DE CONSENTIMENTO LIVRE E ESCLARECIDO

$\mathrm{Eu}$, , portador (a) do RG no.

telefone residente a

Rua no na cidade de menor declaro estar ciente que o mesmo será submetido a um tratamento ortodôntico avaliado e planejado por seu ortodontista responsável associado à aplicação de um laser de baixa potência, fazendo parte da pesquisa científica "Avaliação da influência do laser em baixa intensidade na movimentação ortodôntica", desenvolvida na clínica de pós-graduação da Faculdade de Odontologia da Universidade Metodista de São Paulo, pela aluna Marinês Vieira da Silva Sousa do curso de pós-graduação em Ortodontia da FOB/USP. Permito que o menor suprareferido seja submetido aos exames complementares, dentre os seguintes: radiografias, fotografias faciais e intrabucais, moldagem dos arcos dentários, de acordo com as normas preconizadas pela Agência de Vigilância Sanitária. Se o menor supracitado se recusar a participar da pesquisa relatada, o mesmo não terá seu tratamento ortodôntico prejudicado em hipótese alguma. Por este instrumento que atende às exigências do COMITÊ DE ÉTICA EM PESQUISA da Universidade de São Paulo (FOB/USP), venho informar ao paciente, sobre os procedimentos aos quais será submetido durante $\mathrm{o}$ transcorrer do tratamento e desta pesquisa.

Inicialmente, será solicitado o preenchimento de fichas constando dados pessoais e para o exame clínico odontológico. O ortodontista responsável solicitará uma documentação ortodôntica necessária para o planejamento do caso que incluem radiografias, fotografias, modelos de gesso e também tomografia computadorizada. A documentação ortodôntica será realizada na Universidade Metodista de São Paulo sem nenhum custo ao paciente e as tomografias serão realizadas no Hospital da Face em São Paulo e custeadas por meio de uma verba da FOB/USP (PROAP), já aprovada. Após o pedido das extrações dentárias, instalar-se-á um aparelho ortodôntico fixo, com uma mola de níquel-titânio para retração dos caninos. Na mesma sessão, será aplicado o laser em baixa intensidade na região dos molares e pré-molares a serem ancorados. O laser em baixa intensidade (LBI) consiste em uma radiação luminosa, indolor e não apresenta 
qualquer risco para a saúde bucal destes pacientes, visando apenas diminuir a velocidade da movimentação do dente citado, bem como, diminuir ou inibir a sensibilidade dolorosa que é comum após a ativação do aparelho. Durante a aplicação serão disponibilizados óculos de proteção, que obrigatoriamente deverão ser utilizados. Serão necessárias mais aplicações: três e sete dias após a primeira aplicação, seguindo os mesmos padrões já descritos. Após 30 e 60 dias, o mesmo protocolo será realizado. É importante ressaltar que as emissões do laser são totalmente seguras do ponto-de-vista biológico, ou seja, não produzem mutações e podem ser usadas em crianças e gestantes, desde que se utilizem os cuidados já descritos anteriormente. Os efeitos dos raios laser (LBI) são totalmente benéficos e não produzem efeitos colaterais indesejáveis, portanto é um recurso muito valioso na prática odontológica e tem sido cada vez mais utilizado justamente por possuir uma diversidade de indicações, sendo muitas vezes até dispensado o uso de substâncias farmacológicas que possuem uma infinidade de efeitos colaterais, portanto os pacientes desta amostra serão beneficiados em todos os aspectos por poderem usufruir de um recurso altamente seguro, de alta tecnologia, cujos riscos são praticamente nulos. Durante este processo, o tratamento ortodôntico continuará em seu percurso normal de planejamento, não afetando as condutas necessárias para o seu desenvolvimento clínico adequado, ou seja, os pacientes desta amostra serão duplamente beneficiados por realizarem o tratamento ortodôntico juntamente com os benefícios da laserterapia (redução da dor).

Convém esclarecer que não existem efeitos colaterais, nem quaisquer transtornos deletérios à saúde causado pelo uso do laser em baixa intensidade e que não haverá custos para os pacientes destas aplicações, pelo contrário, trará apenas benefícios, uma vez que a laserterapia já é consagrada na literatura por inibir a dor pós-ativação.

Após o fechamento de espaço promovida pela retração dos caninos, o paciente realizará outra documentação ortodôntica completa igual à documentação inicial, também realizada na Universidade metodista de São Paulo, sem nenhum custo ao paciente.

Deve-se também esclarecer que todas as informações obtidas neste estudo, os modelos, históricos de antecedentes familiares e quaisquer outras informações concernentes ao planejamento e/ou tratamento poderão ser utilizados pela Faculdade de Odontologia de Bauru - USP, para fins de pesquisa, ensino e de 
divulgação em jornais e/ou revistas nacionais e internacionais. Pelo presente instrumento que atende às exigências legais, após leitura minuciosa das informações constantes neste TERMO DE CONSENTIMENTO LIVRE E ESCLARECIDO, devidamente explicada pelos profissionais em seus mínimos detalhes, ciente dos serviços e procedimentos aos quais será submetido, não restando quaisquer dúvidas a respeito do lido e explicado, firma seu CONSENTIMENTO LIVRE E ESCLARECIDO concordando em participar da pesquisa proposta. Fica claro que o sujeito da pesquisa ou seu representante legal, pode a qualquer momento retirar seu CONSENTIMENTO LIVRE E ESCLARECIDO e deixar de participar desta pesquisa e ciente de que todas as informações prestadas tornar-se-ão confidenciais e guardadas por força de sigilo profissional (Art. 9o do Código de Ética Odontológica). Por estarem de acordo assinam o presente termo.

Bauru-SP, de de.

\section{Responsável pelo sujeito da pesquisa Assinatura do Autor}

Em caso de dúvidas ou maiores esclarecimentos contactar a qualquer momento:

Pesquisadora responsável: Marinês Vieira da Silva Sousa tel: (11) 9749-7208 ou (11) 4513-2669. CEP (Comitê de Ética em Pesquisa) tel: (14) 3235-8356 
ANEXO 4

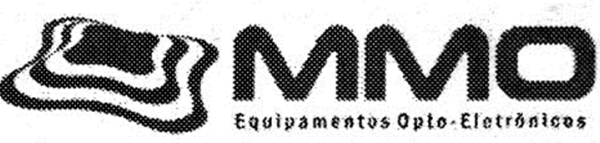

São Carlos, 23 de março de 2010.

Equipamento: TWIN LASER

$N^{\circ}$ série: $\mathrm{T}-941$

Prezada Dra. Marines Vieira S. Sousa

Valores aferidos:

\begin{tabular}{|c|c|}
\hline \multicolumn{2}{|c|}{ Temperatura $=25,6^{\circ} \mathrm{C}$} \\
\hline $\begin{array}{c}\text { Potência } \\
\text { referente }\end{array}$ & $\begin{array}{c}\text { Potência } \\
\text { Aferida }(\mathrm{mW})\end{array}$ \\
\hline 1 & 1,3 \\
\hline 5 & 5,5 \\
\hline 10 & 11,2 \\
\hline 15 & 16,7 \\
\hline 20 & 20,2 \\
\hline 25 & 26,4 \\
\hline 30 & 31,6 \\
\hline 35 & 36,2 \\
\hline 40 & 41,7 \\
\hline
\end{tabular}

\begin{tabular}{|c|c|}
\hline \multicolumn{2}{|c|}{ Temperatura $=25,6^{\circ} \mathrm{C}$} \\
\hline $\begin{array}{c}\text { Potência } \\
\text { referente }\end{array}$ & $\begin{array}{c}\text { Potência } \\
\text { Aferida }(\mathrm{mW})\end{array}$ \\
\hline 1 & 1,7 \\
\hline 5 & 5,5 \\
\hline 10 & 10.1 \\
\hline 15 & 14,9 \\
\hline 20 & 20,2 \\
\hline 25 & 26,4 \\
\hline 30 & 30,2 \\
\hline 35 & 36,4 \\
\hline 40 & 40,8 \\
\hline 50 & 50,1 \\
\hline 60 & 61.3 \\
\hline 70 & 70.7 \\
\hline
\end{tabular}

Qualquer dúvida ou problemas com o equipamento, por favor, não hesite em nos contactar.

Cordialmente,

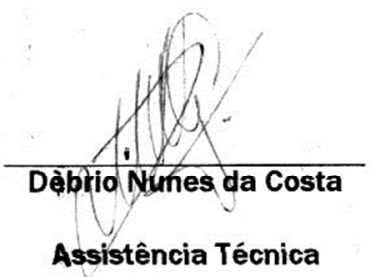

Ww.mmo.com.br

FQ 01.14.04 ver 0

Pág. 1 de 1 


\section{ANEXO 5}

\section{AVALIAÇÃO DA DOR PÓS-ATIVAÇÃO (DENTES SUPERIORES)}

Ficha por arcada - marcar com um "x" qual o nível de dor

Nome:

Data da irradiação:

OBS:caso não haja dor, marcar um " $x$ " no zero

lado direito

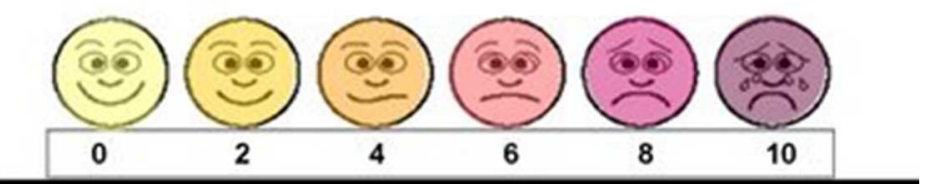

lado direito

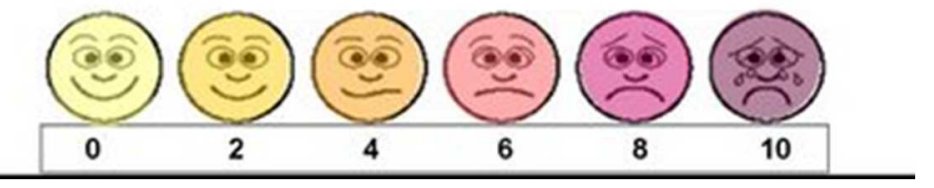

1 dia após(24 horas)

lado esquerdo

lado direito

2 dias após(48 horas) lado esquerdo
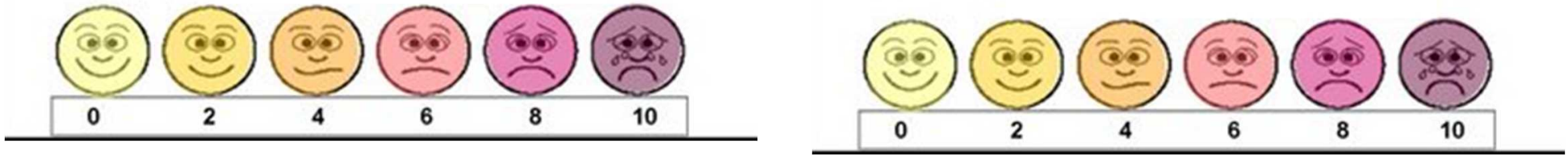

lado direito

3 dias após(72 horas)

lado esquerdo

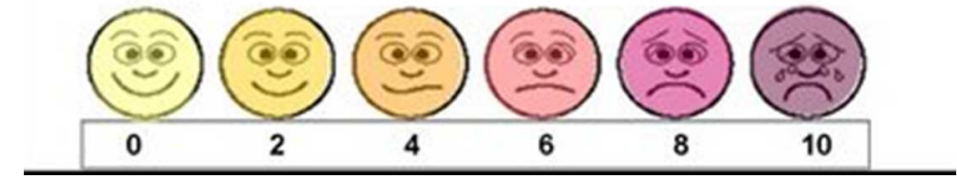

12 horas após lado esquerdo

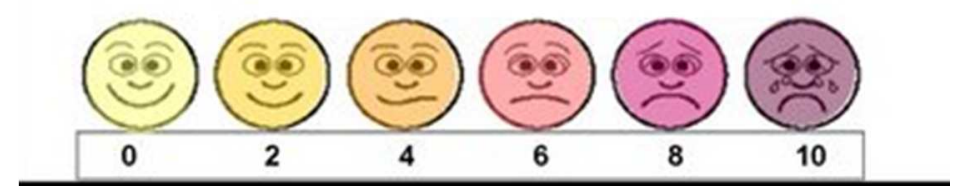




\section{ANEXO 6}

\section{AVALIAÇÃO DA DOR PÓS-ATIVAÇÃO (DENTES INFERIORES)}

Ficha por arcada - marcar com um "x" qual o nível de dor

Nome:

Data da irradiação:

OBS:caso não haja dor, marcar um "x" no zero

lado direito

12 horas após lado esquerdo
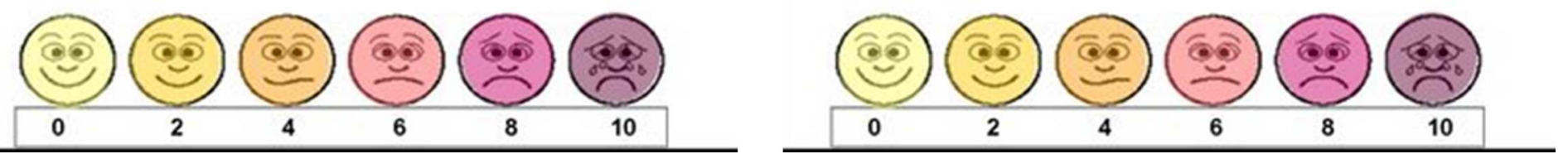

lado direito

1 dia após(24 horas) lado esquerdo
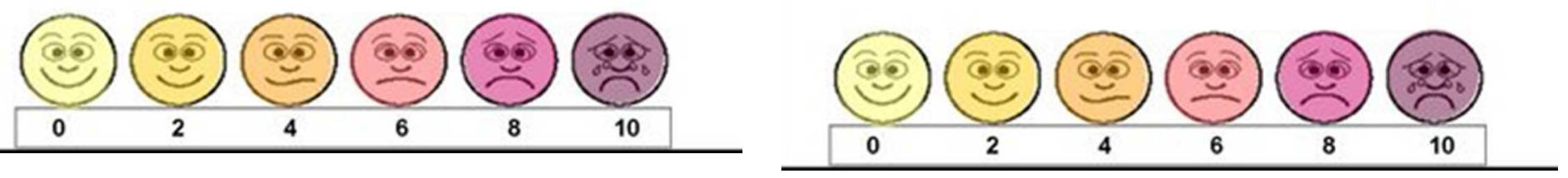

lado direito

2 dias após(48 horas) lado esquerdo
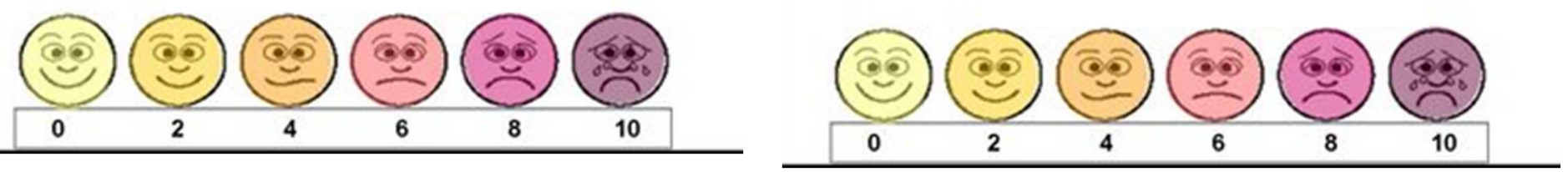

lado direito

3 dias após(72 horas)

lado esquerdo
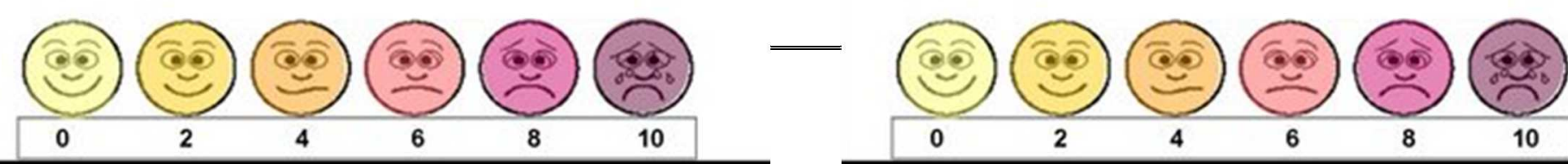